\title{
EDUCAÇÃO AUDIOVISUAL POPULAR NO BRASIL PANORAMA, 1990-2009
}

Tese apresentada ao Programa de Estudos dos Meios e da Produção Midiática da Escola de Comunicação e Artes da Universidade de São Paulo - USP, para obtenção do título de doutor.

Orientadora: Prof. Dra. Esther Imperio Hamburger

Área de concentração: Práticas de Cultura Audiovisual

São Paulo, 2010

2 volumes 
Autorizo a reprodução e divulgação total ou parcial deste trabalho, por qualquer meio convencional ou eletrônico, para fins de estudo e pesquisa, desde que citada a fonte.

\section{Catalogação da Publicação \\ Escola de Comunicações e Artes da Universidade de São Paulo}

Toledo, Moira.

Educação Audiovisual Popular no Brasil - Panorama, 1990 2009/ Moira Toledo; orientador Esther Imperio Hamburger-São Paulo, 2010 361f. 2 v.

Tese (Doutorado) - Universidade de São Paulo, 2010.

1. Do ensino livre e universitário à Educação Audiovisual Popular (EAP).2. Perfil da EAP. 3.Conceitos e práticas de gestão. 4. Estratégias. 5. Resultados. 


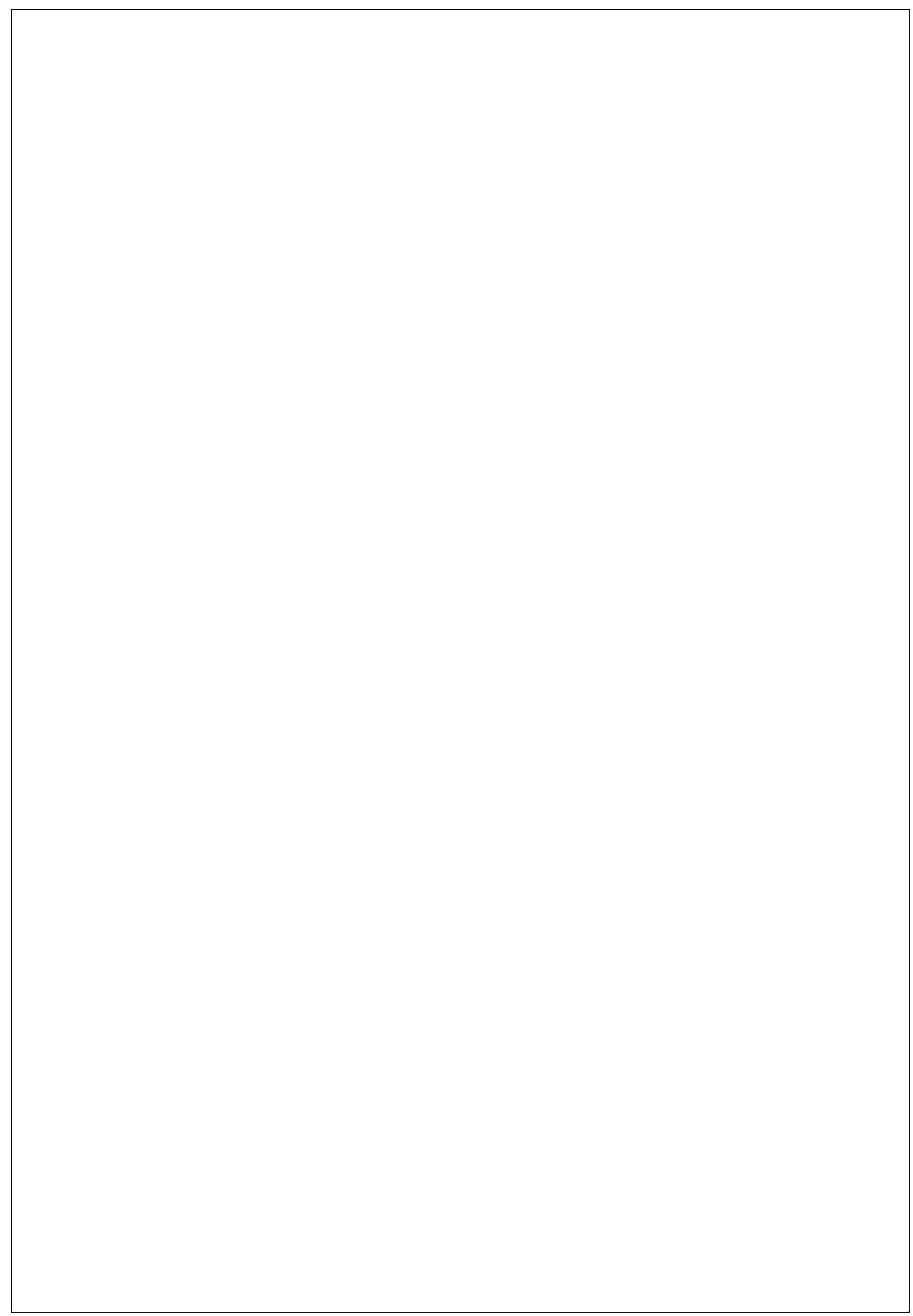


Nome: Moira Toledo

Título: Educação Audiovisual Popular no Brasil - Panorama, 19902009

Tese apresentada ao Programa de Estudos dos Meios e da Produção Midiática da Escola de Comunicação e Artes da Universidade de São Paulo - USP, para obtenção do título de doutor.

Aprovado em 11/05/2010.

\section{Comissão Julgadora:}

Prof. Dr. Henri Gerveiseau (ECA/USP)

Julgamento

Assinatura

Prof. Dr. Maria Dora Mourão (ECA/USP)

Julgamento

Assinatura

Profa Dra. Helena Singer

Instituição_

Julgamento

Assinatura

Prof. Dr. José Gatti

Instituição

Julgamento

Assinatura 


\section{Suplentes}

Profa Dra Rose Satiko

Instituição

Julgamento

Assinatura

Prof. Dr. José Luiz Aidar Prado

Instituição

Julgamento

Assinatura

Prof. Dr. Ismail Xavier (ECA/USP)

Instituição_

Julgamento

Assinatura

Prof. Dr. Luis Fernando Santoro (ECA/USP)

Instituição_

Julgamento

Assinatura

São Paulo

Março/2010 


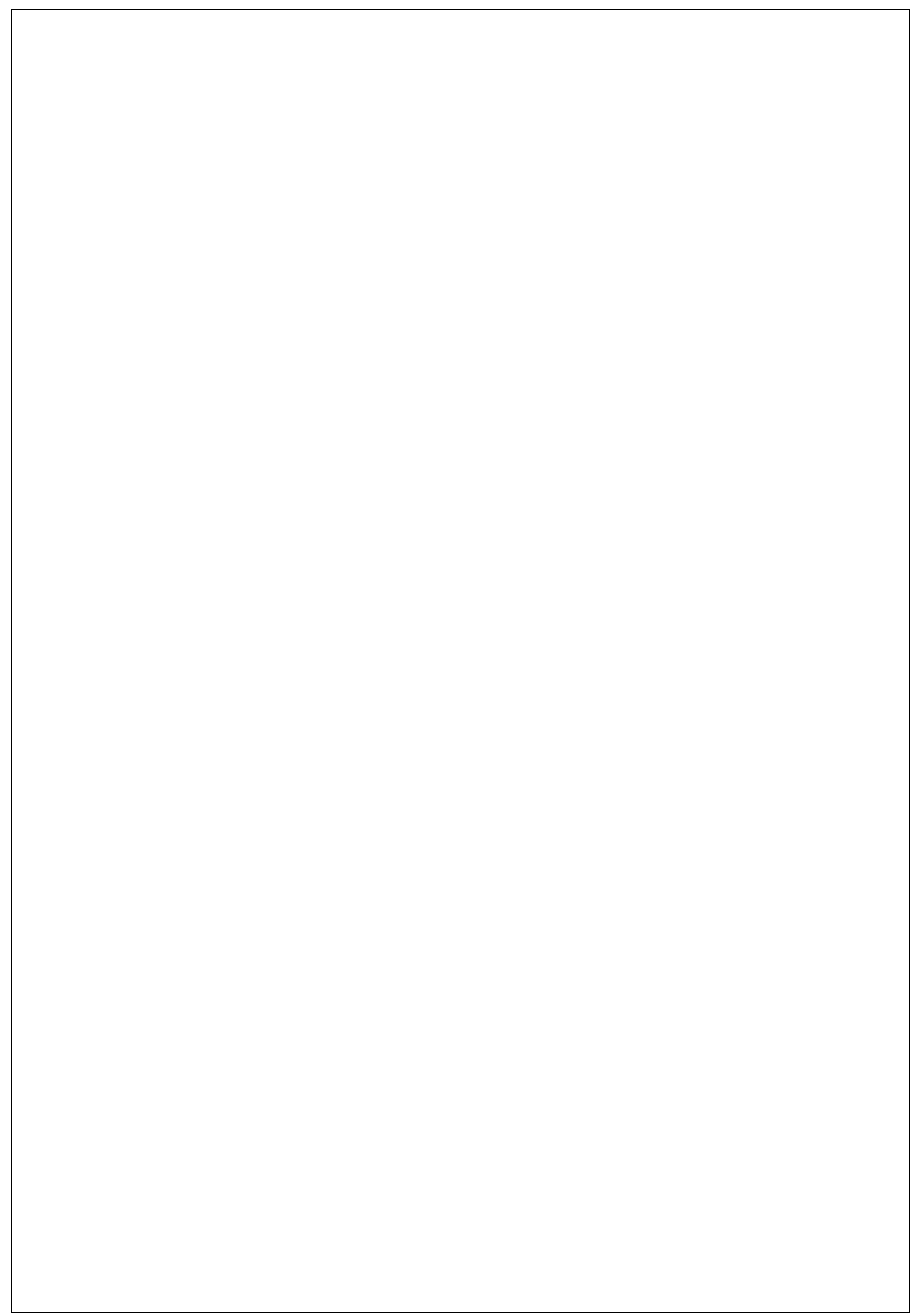


A Cléo Toledo, minha mãe, que me formou a partir da liberdade e criou todas as condições para que a educação democrática fosse para mim algo natural e intuitivo.

A minha companheira Raquel, por todo o infinito apoio e amor, "and cause you inspire me to a better me".

Ao nosso pequeno, amado e já corintiano filho que está a caminho dentro de ti.

E a meu mestre e interlocutor maior, gUi Mohallem. 


\section{Agradecimentos}

Antes de qualquer outra coisa, destaco: esta tese mobilizou uma enormidade de pessoas. Portanto preciso, antes de mais nada, agradecer pura e simplesmente por ter podido contar com tanta generosidade e de tantas pessoas. Foram muitas madrugadas, mas a maior parte delas não passei sozinha. Só posso agradecer. Este trabalho não é só meu, e agradeço.

Esta tese de doutorado é resultado de pesquisa realizada com financiamento do Conselho de Aperfeiçoamento de Pessoal do Ensino Superior.

Esta tese seria impossível sem a contribuição de todas as entidades que atuam no universo da educação audiovisual no Brasil, especialmente aquelas 70 que se dispuseram a responder ao questionário.

Agradeço especialmente a hospitalidade e generosidade dos gestores, coordenadores, educadores e alunos que me receberam de coração aberto para longas e inspiradoras entrevistas:

Zita Carvalhosa (Oficinas Kinoforum-SP), Danielle Fiabane (Instituto Criar de TV, Cinema e Novas Mídias-SP), Chico Serra (Tv Morrinho - RJ) Igor Barradas (Abaeté/Humano Mar-RJ), Márcio Blanco (Observatório de Favelas-RJ), Miriam Machado (Cinema Nosso-RJ), Roberto Robalinho (Alice, prepara o gato!-RJ), Alexia Melo (AIC-MG), Paula Kimo (Oficina de Imagens-MG), César Maurício (Favela é isso aí-MG), Hélio Passos (BH Cidadania-MG) e Cirlan (Tv Morrinho-RJ), gUi Mohallem (Instituto Criar/ELCV e outros-SP); Josinaldo Medeiros (Abaeté/CidadelaRJ); Rodrigo Francisco Corrêa de Oliveira, Victor Dias dos Santos, Fernando Luiz Ferreira Rabelo, Juliana Celestino (Oficina de Imagens-MG); Clebin Santos (AICMG), Zé Luis, Marcos Coelho (Alice, prepara o gato!-RJ); Esteves, Nicholas (Tv 
Morrinho-RJ); Tamiris Lourenço, Diogo Felipe, Carolina Mirati, Taís Cristina, Ivo César da Silva de Oliveira, André Tavares, Maria Teresa (Cinema Nosso-RJ).

Agradeço a minha orientadora, Profa. Dra. Esther Hamburger, por tudo: pelo ambiente de liberdade que propiciou, em sintonia com o tema do trabalho; por ter acreditado no potencial do meu trabalho, sempre, e por ter oferecido orientação e suporte em todas as crises e voltas por cima.

A Henri Gervaiseau e à Helena Singer pelas sugestões e críticas feitas na qualificação, que mudaram o rumo dos acontecimentos de maneira irreversível, me conduzindo, por fim, aonde eu devia de fato ter ido.

Agradeço especialmente a Helena Singer, cuja paixão por difundir a Educação Democrática contribuiu por expandi-la e fazê-la chegar a educadores intuitivos como eu.

A toda a equipe da Ouroboros, que tomou conta da casa com propriedade enquanto estive fora e permitiu que de alguma maneira nosso sonho continuasse a crescer: Marina Weis, Marina Santonieri, Thiago Ribeiro, Carolina Lutz Setúbal, Alexandre Rodrigues "Sorriso", Raquel Diamant, Leonardo Cubas Gusmão, Danielle Almeida, Indianara Nonzamo, Jadson Rocha, Luiza Fagá.

À Associação Cultural Kinoforum e toda a sua equipe, especialmente Vânia Silva, que me auxiliou imensamente na promoção dos questionários, e Vanessa Reis, parceira em toda essa longa jornada, minha querida sucessora na Formação do Olhar e grande interlocutora nesses anos de pesquisa. Além de ter contribuído de maneira decisiva no processo de coleta de dados e sistematização do capítulo 1.3.2.

A Zita Carvalhosa, parceira, incentivadora, uma apaixonada pela educação audiovisual e sempre aberta a novas ideias com sua lucidez admirável.

Aos meus alunos da Oficina de Cinema no Jaraguá, em 2001, literalmente cobaias da minha paixão por ensinar. 
A todos os meus alunos, especialmente das Oficinas Kinoforum, ELCV e Cine Tela, que sempre me deram liberdade para experimentar e tiveram desejo de construir ideias e caminhos juntos comigo.

A Zé Luis Aidar Prado, grande amigo e inspirador, sempre pronto a me acalmar nos bloqueios criativos e desesperos científicos, desde o mestrado and beyond....

A Gustavo Souza, por compartilhar suas entrevistas e, especialmente, por escutar meus desabafos e me conduzir pela mão até os rituais da academia: até me cadastrou nas listas da Compós, um fofo... E foi a melhor companhia nos congressos e salas de aula, ever!

A Dani, Marina Santô, Luiza Fagá, Indianara Nonzamo, Mônica Cardella, Luma Reis, Edson Costta e Ju Cavalcanti pelo apoio em diversos aspectos práticos em toda a caminhada. E a toda a equipe de transcrição das entrevistas que, se não trabalhou de graça, trabalhou com graça e quase de graça.

Aos assistentes de pesquisa Lucélia Fernanda e, especialmente, Ariel Rolim e Marina Conrado, que dedicaram dias e madrugadas tabulando dados e me ajudando a cumprir os prazos e compromissos. E a Rafael Mantovani pela ajuda inestimável nas últimas horas!

A Henrique Landulpho, que me doou um Office original (quem faz isso?) por generosidade — ainda foi me levar, acredita? - e me salvou do caos digital.

A Renata Pieratti Bueno, nova amiga antiiiga, confidente e futura médica da família toda! E a Eduardo Valadares, pelas preciosas leituras sobre educação democrática e libertária.

A Thiago Salles Gomes pela eterna disponibilidade para minhas dúvidas filosófico-existenciais, paciência com minhas crises intelectuais e fundamental 
orientação para o estabelecimento das hipóteses desta pesquisa. E a Cris Massoco, pessoa incrível, grande amiga e querida, sempre por perto com um palavra doce e um olhar mais ainda.

A Henry Grazinoli, Danilo Solferini, Eduardo Barioni, Vera Haddad, Estevan Santos e outros educadores que se doaram aos projetos nos quais vivenciamos processos democráticos e intensos, educadores cuja paixão por ensinar me inspirou e com os quais ainda pretendo trabalhar muito. Especialmente ao querido e amado Maurício Abud - triste pela saudade, mas certa de que nos divertimos juntos no pouco tempo que dispusemos para brincar de educar - (e que eu sei que ele diria, bem a seu jeito, que foram "uma delícia, Moiramada!!”).

A Fernanda Diamant, paradoxalmente cunhada e irmã, melhor papo da cidade, refletidos em horas diárias e semanais de bate-papo e apoio mútuo ao longo desta tese como dos últimos quinze anos... A Sandra Diamant pelo apoio incondicional e sem preconceitos a todos os momentos desta nossa família diferente e especial. A Marta Toledo, Dirceu Moraes e Irina Moraes pela paciência e amor nesses anos de semisumiço.

A todos os amigos que agüentaram as consequências da minha clausura. Todos, obrigada pela paciência. Eu ainda amo vocês, muito.

A Fábio Cirello, meu pai, pelo amor incondicional, e a Yô Cirello, sua esposa, que deu um suporte amoroso, inesperado e decisivo na reta final da reta final, ou seja, quando eu mais precisava.

A minha irmã querida e muito amada Isabella, a quem eu amo e vou sempre amar, de perto ou de longe, sem perder a esperança de que um dia os doze anos de diferença que nos separaram por tantos anos comecem a nos aproximar.

A Ana Paula Gomes que, uma vez mais, deu estilo e fluência ao meu texto. E sem prazo, sem sistema, com muito amor e paciência com a doutoranda em desespero... Em suma, uma linda! 
A Carol Lutz Setúbal, a Pi, por tudo, tudo mesmo: pela parceria espiritual que vai, a cada momento, se materializando em uma nova descoberta; pela disponibilidade e poder absurdo (e um tanto único) para me acalmar a qualquer hora, recriando as palavras da Lama (que nunca vi!), e de me fazer sentir budista sem jamais pisar num templo; pela companhia e investimento pessoal nas viagens e entrevistas da tese; e por essa generosidade que você diz que espelha e eu digo que você propaga. Pure entanglement.

A Olivia Janequine, minha babá intelectual, a cientista que pôs esta cineasta na "fôrma" e cuja assessoria na reta final foi decisiva para que a tese tomasse a forma que tomou e, enfim, podemos até supor, que ela saísse por fim. Cabeça brilhante, coração imenso, me conduziu para uma apropriação real e concreta das coisas mesmas que eu vinha propondo, e ensinou coisas e processos que vão ficar para a vida.

E ao Thi, por ter nos dado (a mim e à Ra) o maior presente que um amigoirmão poderia dar: amor em forma de um filho. Te amo. 
“A experiência social em todo o mundo é muito mais ampla e variada do que o que a tradição científica ou filosófica ocidental conhece $e$ considera importante. Em segundo lugar: esta riqueza social está a ser desperdiçada."

(Boaventura de Souza Santos, 2006, p. 94) 


\section{Resumo}

TOLEDO. Moira D.G.C. Educação Audiovisual Popular no Brasil - panorama da experiência 1990-2009. 2010. 361f. Tese (Doutorado) - Escola de Comunicações e Artes, Universidade de São Paulo, 2010.

Esta tese apresenta um mapeamento da experiência de oficinas e cursos livres audiovisuais gratuitos no Brasil, entre 1990 e 2009, a partir dos desafios, práticas e trajetórias pedagógicas compartilhadas pelas entidades que os promovem. Buscou-se estabelecer as principais intencionalidades, sistematizar meios comuns e apresentar meios extraordinários utilizados para promovê-las, bem como refletir sobre os principais resultados obtidos, na tentativa de identificar como e quando encontram o melhor de seu potencial. Para tanto realizamos e aplicamos 198 questionários e entrevistas, com profissionais oriundos de 70 entidades de todo o país, cujos resultados serviram de ponto de partida para as análises subsequentes. Os dados coletados e análises realizadas indicaram que os profissionais de tais entidades revisitam — e em alguma medida recriam — princípios filosóficos, teorias e práticas de campos correlatos da educação, especialmente do subcampo que identificamos como o das educações alternativas e democráticas. As entidades vêm alcançando excelentes resultados sob parâmetros diversos, o que sugere que tais princípios filosóficos, teorias e práticas —integradas à promoção de aprendizados como o audiovisual - têm potencial para promover a superação de desafios crônicos do âmbito das escolas formais e inspirar o desenvolvimento de políticas públicas.

PALAVRAS-CHAVE: educação audiovisual, cinema, educação democrática", pedagogia, comunicação. 


\begin{abstract}
TOLEDO. Moira D.G.C. Media Literacy in Brazil - an overview 1990 - 2009. 2010. 361f. Tese (Doutorado) - Escola de Comunicações e Artes, Universidade de São Paulo, 2010.

The present work introduces a mapping of the experience of cost-free media workshops and courses in Brazil, between 1990 and 2009, based on the shared educational challenges, practices and histories of the entities that provide them. The aim was to establish major intents, systemize common strategies and present extraordinary strategies that are used to provide them, as well as reflect on the major results obtained, with view to identifying how and when they achieve their best potential. For that purpose we have designed and employed 198 questionnaires and interviews with professionals from 70 entities around the country, the result of which served as an offset for subsequent analyses. The collected data and the analyses carried out have shown that the professionals from such entities revisit - and to some extent recreate - theories, practices and philosophical principles from correlated fields of education, especially from the subfield we have identified as pertaining to alternative and democratic education. These entities have been achieving excellent results by many standards, which suggests that such theories, practices and philosophical principles - integrated to the promotion of literacies, such as media literacy - have a potential to encourage the overcoming of chronic challenges faced by formal schools and to bring about the development of public policies.
\end{abstract}

KEYWORDS: media literacy, cinema, democratic education, pedagogy, communication. 


\section{Sumário}

INTRODUCÃ̃ $\ldots \ldots \ldots \ldots \ldots \ldots$

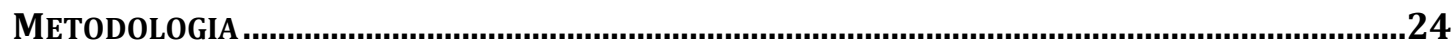

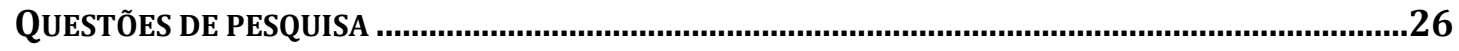

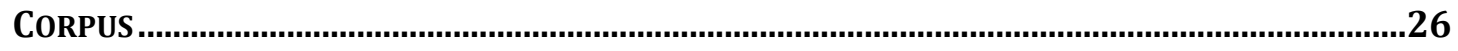

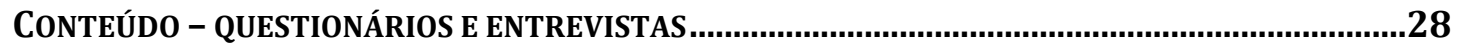

SEGUNDA ETAPA - ENTREVISTAS E QUESTIONÁRIOS ADICIONAIS ...............................................30

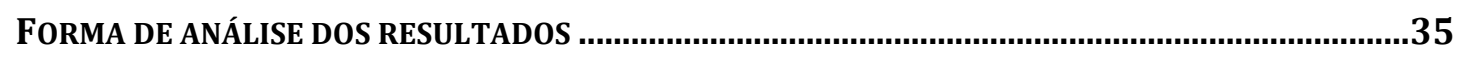

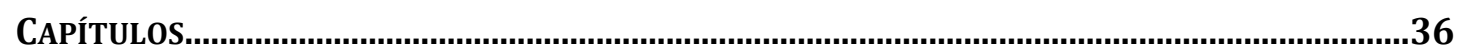

\section{DO ENSINO LIVRE E UNIVERSITÁRIO À EDUCACCÃO AUDIOVISUAL POPULAR -}

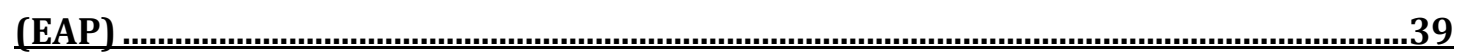

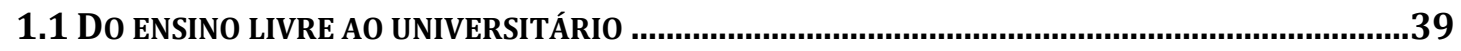

1.2 Do víDEO POPULAR À EAP ..........................................................................................50

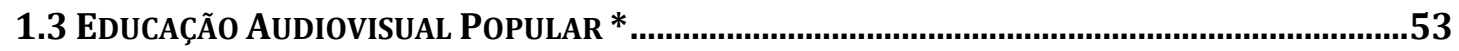

1.3.1 PRIMEIROS CONCEITOS - UMA VISÃO ETIMOLÓGICA DA EXPERIÊNCIA .... 53

1.3.2 FRONTEIRAS HISTÓRICAS ............................................................................................. 56

1.3.3 ANOS 2000 - UMA VISÃO EVOLUTIVA E POLÍTICA …………………….................... 59

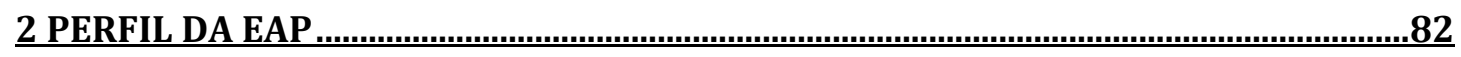

2.1 GEOGRAFIA DA EAP - UM FENÔMENO URBANO …............................................................82

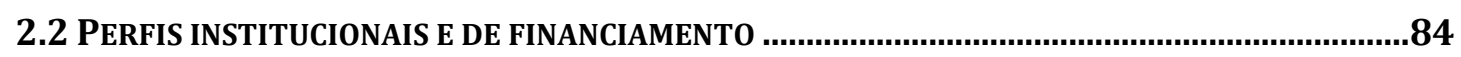

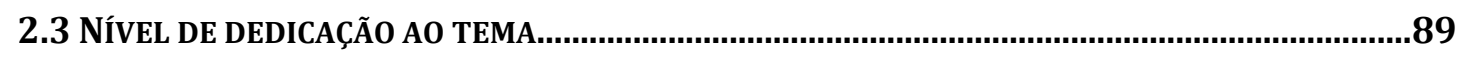

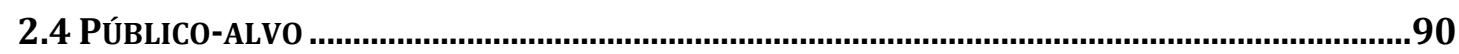

2.5 INTENCIONALIDADES

2.6 QUE HABILIDADES O ENSINO AUDIOVISUAL PODE AJUDAR A DESPERTAR? …….......................92

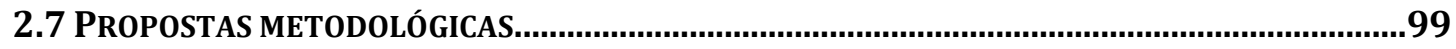

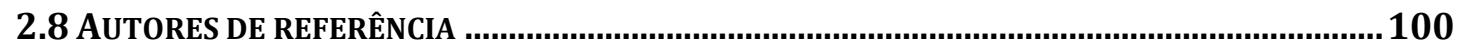

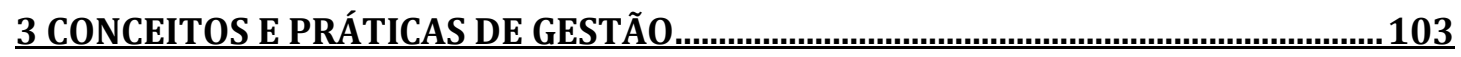




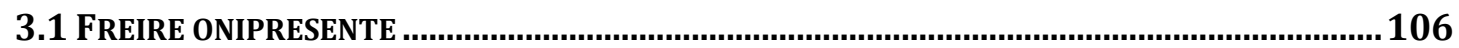

3.2 UM OUTRO CAMINHO A PARTIR DE FREIRE - EDUCAÇÃo E COMUNICAÇÃo ........................... 109

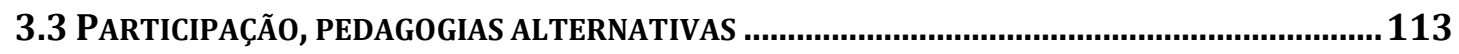

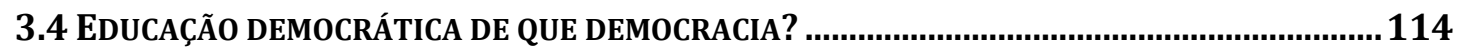

*3.4.1 SISIFIANAS, OU EM BUSCA DE UMA DEFINIÇÃO ...............................................117

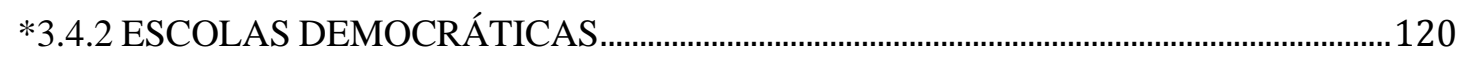

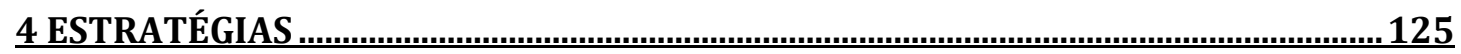

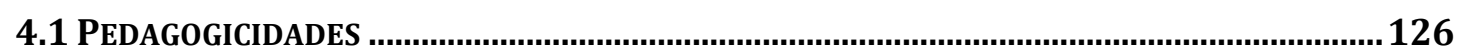

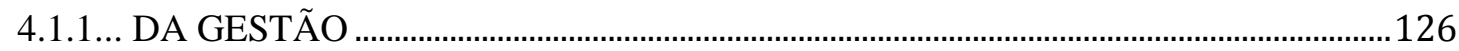

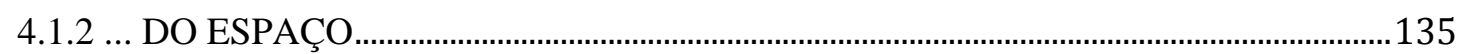

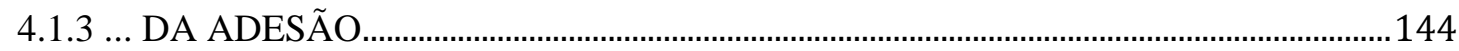

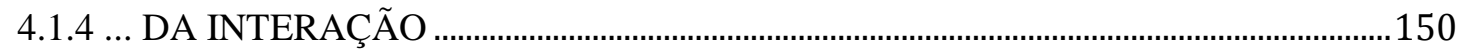

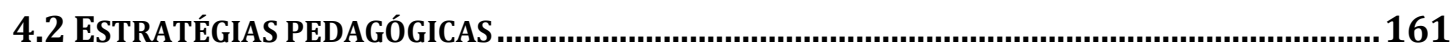

4.2.1 PROJETOS DE PERFIL 1 - CICLO CURTO E ALTA CARGA HORÁRIA

RELATIVA (20 a 160H/AULA)_................................................................................... 165

4.2.2 PROJETOS DE PERFIL 2 - CICLO INTERMEDIÁRIO E CARGA-HORÁRIA DE

BAIXA A INTERMEDIÁRIA (MÁXIMO DE 400H/AULA) .................................................182

4.2.3 PROJETOS DE PERFIL 3 - DURAÇÃO INTERMEDIÁRIA E LONGA; E ALTA

CARGA HORÁRIA (400 A MAIS DE 800h)

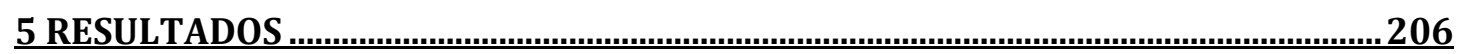

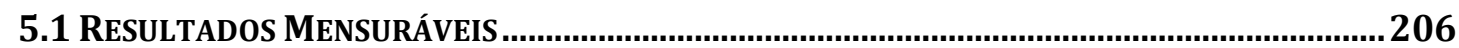

5.1.1 VIDEOS PRODUZIDOS, FESTIVAIS, TELEVISÃO ………………………………......206

5.1.2 PROFISSIONALIZAÇÃO E INSERÇÃO EFETIVA.....................................................213

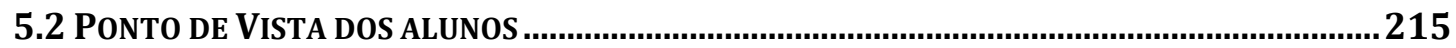

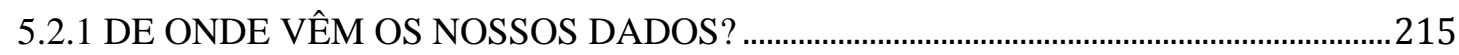

5.2.2 BREVE PREFÁCIO AO SUBCAPÍTULO …………….......................................................2. 217

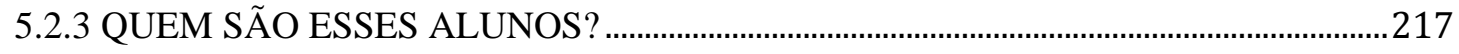

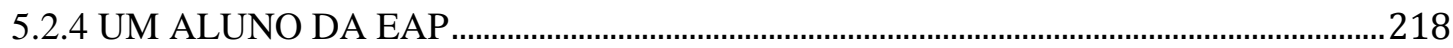

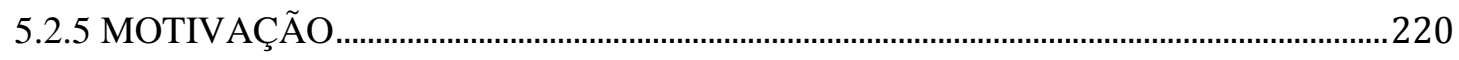

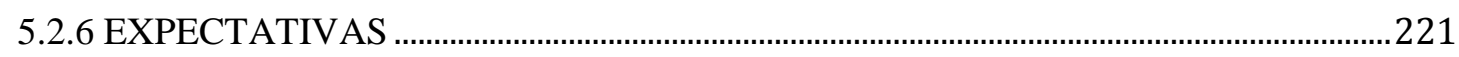

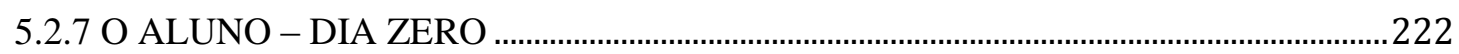

5.2.8 UM FILME IMAGINÁRIO.................................................................................................222

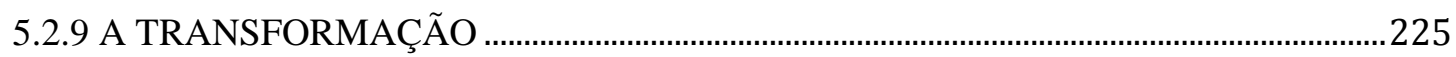




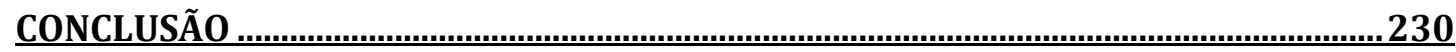

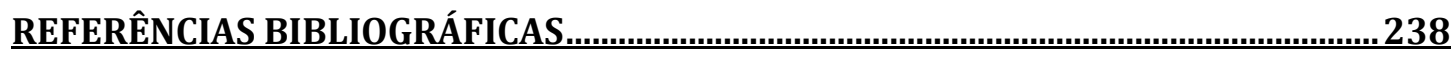

APÊNDICE A - ALUNOS ENTREVISTADOS VIA QUESTIONÁRIO ON-LINE ....244

ANEXO A - LISTA TOTAL DE 113 ENTIDADES MAPEADAS.................................248

ANEXO C - CARTA DE SAÍDA DO CINEMA NOSSO

ANEXO D - CARTA DE SAÍDA DO COLETIVO DE VÍDEO POPULAR.................259

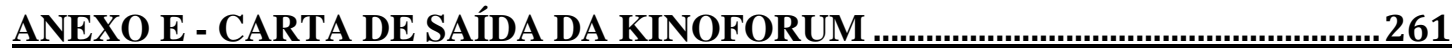

ANEXO F - CARTA RESPOSTA DO FEPA À SAÍDA DOS GRUPOS ........................ 263

ANEXO G - UMA ATUALIZACÃO SOBRE AS REPRESENTACÕES DA EAP_....266

ANEXO H - QUESTIONÁRIO - ENTIDADES DE EDUCACÃO AUDIOVISUAL

POPULAR

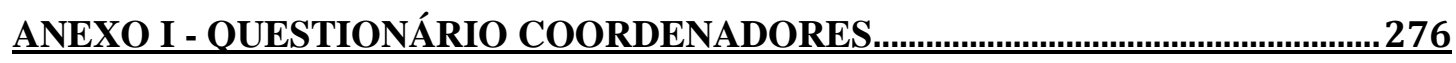

ANEXO J - QUESTIONÁRIO EDUCADORES

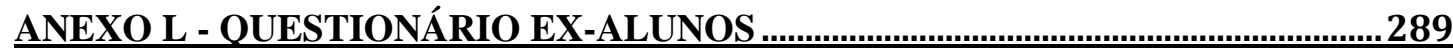

ANEXO M - EDITAL VAI

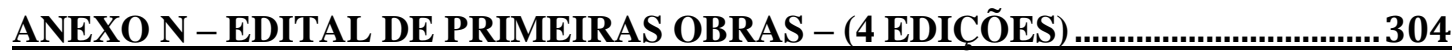

ANEXO O - EDITAL DE EGRESSOS 


\section{Introdução}

No ano de 2001, estava cursando o terceiro ano da faculdade e acabava de lançar meus primeiros curtas-metragens em $16 \mathrm{~mm}$. Tinha planos para atuar como diretora cinematográfica, com roteiros de longa-metragem em desenvolvimento e um projeto de vida definido. E não imaginava o quanto ele estava por se transformar, quando fui convidada pela então recém-fundada ONG Projeto Perifa para coordenar uma Oficina de Cinema em $16 \mathrm{~mm}$ para adolescentes de um bairro da periferia de São Paulo, juntamente com meu parceiro de longa data, o fotógrafo Thiago Ribeiro.

Entre esta oficina realizada em uma escola pública no bairro do Jaraguá (na cidade de São Paulo), nos anos de 2001 e 2002, e o presente momento, me formei cineasta, conclui um projeto de mestrado e realizei alguns filmes, como havia previsto. Mas me dediquei, de fato, e com muita paixão, a atuar como educadora e coordenadora pedagógica de projetos gratuitos de ensino de audiovisual, realizados especialmente em comunidades de baixa-renda.

Atuei em funções diversas em mais de 10 projetos $^{1}$, nos estados de São Paulo, Rio de Janeiro, Paraná e Piaú́. Viajei a cerca de 20 cidades, do interior e litoral destes estados, onde atuei em mais de 70 edições das diferentes oficinas. Fui professora ou coordenadora de aproximadamente 1600 alunos.

Durante esses dez anos, meu perfil de atuação foi se transformando: da atuação na chamada "linha de frente" - como educadora e coordenadora pedagógica dos projetos propriamente ditos -, passei a atuar também como curadoracoordenadora de projetos de difusão. Como coordenadora da Seção Formação do

\footnotetext{
${ }^{1}$ Atuei nos seguintes projetos: Oficinas do Projeto Perifa, 2001, educadora; Oficinas Kinoforum (OKIN), 2003, educadora; Oficina do Núcleo de Estudos da Violência, 2003, educadora; Casa do Zezinho, 2004, educadora voluntária; Oficinas de roteiro e direção do Festival do Piauí, 2004 educadora; OKIN, 2004-05, colaboradora pedagógica; Instituto Criar de TV e Cinema, 2006, coordenadora pedagógica; Escola Livre de Cinema e Vídeo de Santo André (ELCV), 2007-09, supervisora artística e pedagógica; Oficina de Formação de Educadores-aprendizes, 2007, coordenadora; Oficinas de Documentário do Centro de Cultura Judaica (2007-08), coordenadora; Oficinas Tela Brasil - SP, RJ e PR (2007-2010), coordenadora e supervisora pedagógica; Oficina de Introdução à Educação Audiovisual Democrática, 2009, coordenadora
} 
Olhar desde 2004, seção do Festival de Curtas de SP dedicada à produção resultante de oficinas audiovisuais gratuitas, conheci e tive ampla interlocução com coordenadores, educadores e alunos de projetos de todo o país. Durante cinco anos como coordenadora da seção, assisti a mais de 500 vídeos, planejei e mediei 2 debates por ano, fui editora de 4 tablóides dedicados ao tema, e recebemos convidados de 15 estados.

Mais recentemente, desde 2005, venho também atuando de forma mais direta em oficinas e projetos de formação pelos quais passaram mais de 100 jovens educadores de audiovisual.

Ao longo dos anos, fui percebendo, com surpresa, que na verdade, o campo da “educação audiovisual” não existia como tal. E que não existiam tampouco diretrizes bibliográficas para a atuação de seus pretensos profissionais (como eu) - o que de certa forma sempre foi um pouco perturbador. E a um só tempo, também libertador e inspirador.

Mesmo o termo, educação audiovisual, sempre esteve longe de ser um consenso - eu notava isso na prática, tanto nos projetos como na forma como eram e são tratados na mídia e na academia.

Essa experiência, de participar de diferentes oficinas e cursos livres, e desde 2004, da Formação do Olhar, me permitia acompanhar de perto a diversidade de desafios cotidianos, bem como o amadurecimento das estratégias utilizadas para superá-los. Acompanhei a evolução das terminologias utilizadas pelos próprios agentes como pela mídia, dentre outros aspectos, e integrei, de alguma maneira, a construção coletiva de um pensamento político que paulatinamente incluiu esta experiência compartilhada - e que opto por aqui chamar "Educação Audiovisual Popular" (EAP) - em diversas políticas públicas de âmbitos municipais e federais, especialmente a partir 2005 .

E nesse período, principalmente, experimentei um desalento entre "profissionais da Educação Audiovisual Popular", especialmente educadores, 
coordenadores e gestores. São profissionais de um campo inexistente; raramente contratados com registro em carteira de trabalho; oriundos de áreas de formação as mais diversas e sem acesso a referências bibliográficas nos segmentos em que atuam: ensino de cinema/audiovisual para o público infantil e juvenil.

Esse, que era um desalento meu também, converteu-se por fim em motivação para investigar as experiências em detalhe, e buscar, na própria vivência de campo, algum registro e sistematização dessa década de amadurecimento, bem como apontar para uma amarração conceitual que historicamente seguia omitida.

Desenvolvíamos, na condução do Festival, possivelmente o até hoje mais completo banco de dados referente às experiências de todo o país, diversas vezes consultado por instâncias desenvolvedoras de políticas públicas, pesquisadores e interessados em geral. Este banco de dados foi gerenciado pela equipe do Festival, durante anos, como ferramenta de trabalho, mas também como registro histórico.

Durante esse tempo, tive a oportunidade de acompanhar a transformação da produção nacional que resulta destas experiências - no Festival e, a partir de 2007, também com a idealização e realização do site KinoOikos ${ }^{2}$ - e das metodologias empregadas para ensinar audiovisual em diferentes projetos nos quais atuei. Com motivos de sobra (paixão pelo tema, experiência acadêmica e como educadora) e recursos à mão (banco de dados completo, acesso ao acervo do Festival e encontros anuais com coordenadores e educadores de todo país), não tive dúvidas. O propósito do meu trabalho definiu-se de imediato: investigar os meios pelos quais essa educação tem sido promovida, especialmente entre educadores, coordenadores, gestores e, ainda, sob a ótica dos alunos.

Parti para esta jornada com muitas questões, mas apenas uma certeza: era perceptível, dentre as diferentes e distantes experiências, uma unidade involuntária, típica de um Zeitgeist, do "Espírito de uma época", em torno de determinados meios de se compreender e promover os aspectos pedagógicos das experiências. Foi esse

\footnotetext{
${ }^{2} \mathrm{O}$ site www.kinooikos.com é uma realização da Associação Cultural Kinoforum e do Festival Internacional de Curtas de São Paulo, em coprodução com a Ouroboros, minha produtora. Tem como objetivo dar visibilidade à produção audiovisual resultante de oficinas gratuitas realizadas em todo o país. Todos os vídeos disponíveis no site podem ser baixados e exibidos em projetos sem fins lucrativos, através de licença creative commons.
} 
Zeitsgeist, materializado em ações práticas e discursos, que se tornou imediatamente objeto da minha investigação.

Entre 2006 e 2009, visitei 12 entidades nos estados de São Paulo, Rio de Janeiro e Minas Gerais, nas quais realizei um total de 21 entrevistas (documentadas em vídeo), conversando com um total de 30 pessoas. Realizei também 165 entrevistas virtuais, a partir de quatro questionários disponibilizados na Internet: 65 através de um questionário geral principal voltado às entidades, 7 através de um questionário voltado especificamente a coordenadores, 11 através de questionário específico para educadores, e 82 através de questionário específico para alunos/ex-alunos.

Foram utilizadas ainda três entrevistas realizadas, e generosamente compartilhadas, pelo pesquisador e amigo Gustavo Souza para sua tese de doutoramento $^{3}$ que está em progresso. Entre questionários e entrevistas, coletou-se um total de 198 diferentes pontos de vista, de diferentes âmbitos e agentes envolvidos com a experiência.

Quando fui a campo, notei de que se tratava de um conjunto expressivo de experiências. O resumo das apurações feitas em campo indicou que, entre 1990 e 2009, ao menos 26 mil alunos foram formados em oficinas e cursos livres audiovisuais (não universitários) promovidos por, no mínimo, 113 diferentes entidades do país. Foram realizadas ao menos 3300 produções audiovisuais de curta e média-metragem, a maior parte delas por alunos jovens e moradores de bolsões de pobreza das capitais do país. Elas estão ou foram registradas em todas as regiões do país, em 18 Estados da Federação e no Distrito Federal. São apenas algumas dentre as diferentes estatísticas estabelecidas, números expressivos que demonstram o expressivo volume de recursos, dedicação criativa e profissional de diferentes segmentos da sociedade, para explorar e desenvolver aspectos e potencialidades do audiovisual como ferramenta de ensino. Mas, à luz desses dados, o que justificaria tamanha dedicação e investimento?

É de se supor que o ensino audiovisual, nesses contextos, se desenvolve como

\footnotetext{
${ }^{3}$ Tese de doutoramento em realização na ECA/USP, sob orientação do professor Henry Gervvaiseau, como o título provisório "Pontos de vista em documentários periféricos". A previsão de término (depósito) é fevereiro de 2011.
} 
mímese do ensino em ambientes universitários; ou inspirado em métodos construtivistas de ensino de arte, bastante comum em entidades do terceiro setor. E, de fato, parte dos educadores e coordenadores que atuam na área tem essas origens e estratégias de abordagem. No entanto, a expansão da experiência levou ao surgimento de diversos novos projetos de educação audiovisual, e houve uma demanda maior do que a oferta: faltaram no mercado novos educadores e coordenadores para criar e implantar projetos na área. Essa busca por "talentos" permitiu que diversos profissionais e interessados por audiovisual, cinema e comunicação, que nunca haviam se imaginado em tal posição, se tornassem também profissionais da educação.

Há, dentre os educadores e coordenadores, cineastas, comunicadores, artistas plásticos, professores de escolas públicas, psicólogos, antropólogos, pedagogos, assistentes sociais, fotógrafos, arquitetos, publicitários, dentre outros. Mas o que há, de fato, em comum entre eles é que, uma vez dedicados ao ensino audiovisual, no momento de desenvolver seu plano de trabalho, descobrem-se sozinhos: não há no Brasil cursos de formação ou bibliografia de fôlego que auxilie aquele que pretende ensinar audiovisual fora do contexto universitário ${ }^{4}$. Mesmo para este contexto, a literatura é mínima.

Sempre houve um natural isolamento, que por fim revela-se altamente fértil pedagogicamente, pois percebemos a emergência de uma série de princípios e práticas criativos e similares entre si que acabam distantes no tempo-espaço. Práticas que, em geral, recusam os dispositivos disciplinares - comuns nos estabelecimentos escolares - e valorizam a participação do aluno e o desenvolvimento de sensos de responsabilidade e autonomia, apontando para um diálogo, muitas vezes inconsciente, com várias experiências teóricas consideradas alternativas a um modelo mais hegemônico.

A principal consequência prática dessa confluência de características muito específicas é a criação de meios originais e criativos para ensinar audiovisual - muito distintos dos modelos universitário e cineclubista -, e que vêm obtendo excelentes resultados. E uma consequência secundária, porém, não menos relevante, é que a

\footnotetext{
${ }^{4}$ No final do ano de 2009, a UFF aprovou a criação do primeiro curso de Licenciatura da Área Audiovisual. Nada mais se sabe até o momento.
} 
experimentação de estratégias pedagógicas que buscam - como outras tendências de educação alternativas - resolver vários desafios comuns e ainda não superados pelo contexto escolar, demonstram que a Educação Audiovisual Popular pode ser também um privilegiado "laboratório de pesquisas", em que a educação formal pode se inspirar para renovar suas práticas.

\section{Metodologia}

Fui muito bem recebida em todas as OSCIPs, entidades e projetos por onde passei. É certo que minha longa atuação na área, bem como o prévio relacionamento profissional, e muitas vezes até de amizade, que tinha com muitos educadores e coordenadores, abriu muitas portas. Fui recebida em mais de uma dezena de entidades que expuseram com generosidade seus processos e ideias.

No entanto, uma entidade me fez alguns questionamentos antes de autorizar o meu acesso: "Quais os objetivos de minha pesquisa? Eu retornaria à entidade para dar um retorno, um "feedback" sobre os resultados da mesma? Ela teria impacto sobre a atuação de seus profissionais?"

O incômodo foi facilmente compreendido: ao longo dos anos, diversos pesquisadores teriam realizado pesquisas e entrevistas na entidade, sem que isso implicasse, no entanto, em alguma espécie de retorno; por exemplo, através do envio de exemplares das teses resultantes. Esse distanciamento entre os pesquisadores e as entidades foi também objeto de muita crítica em outras entidades. Trata-se de uma preocupação central na construção desse objeto e da metodologia da pesquisa. Dessa forma, combater o trágico destino de grande parte dos trabalhos científicos também foi uma preocupação constante durante o presente trabalho. ${ }^{5}$

Os problemas levantados, bem como as hipóteses estabelecidas, visam, em última instância, oferecer sistematizações e propostas para conflitos e desafios

\footnotetext{
${ }^{5}$ Segundo Oliveira e Oliveira, o destino desses trabalhos é,“quase sempre as gavetas e estantes das bibliotecas universitárias, onde sua tranquilidade só será perturbada, de vez em quando, por outro estudante em busca de referências ou citações para sua própria pesquisa." (OLIVEIRA, R. D. D.; OLIVEIRA, M. D. D., 1981, p. 18)
} 
cotidianos para profissionais (e esse é o meu caso) que não têm muita bibliografia à qual recorrer. Buscamos investigar a experiência da EAP e, ao mesmo tempo, auxiliar o seu desenvolvimento. Em diálogo com a pesquisa participante, como enunciado aqui por Brandão:

Conhecer a sua própria realidade. Participar da produção deste conhecimento e tomar posse dele. Aprender a reescrever a História através da sua história. Ter no agente que pesquisa uma espécie de gente que serve. Uma gente aliada, armada dos conhecimentos científicos que foram sempre negados ao povo, àqueles para quem a pesquisa participante - onde afinal pesquisadores e pesquisados são sujeitos de um mesmo trabalho comum, ainda que com situações e tarefas diferentes - pretende ser um instrumento a mais de reconquista popular. (BRANDÃO, 1981, p. 11)

Dialoga-se, flerta-se com estes ideais da Pesquisa Participante (PP) com algum idealismo, mas também com plena consciência de que as fronteiras entre este e a passionalidade são tênues, buscando sempre manter algum rigor científico, mesmo nas zonas cinzentas. Quando, por exemplo, a minha experiência pessoal me permitia acrescentar informações não ofertadas diretamente pelos entrevistados, procurei diferenciar, no texto, o discurso efetivo dos mesmos, e a minha visão subjetiva dos fatos.

Apenas existe um "flerte" com a PP porque, durante o processo de elaboração da tese, foi preciso fazer uso de estratégias e instrumentos de coleta (como questionários) com ela que pareciam virtualmente incompatíveis. Optei, finalmente, por realizar apenas um diálogo criativo, materializado em duas estratégias principais:

a) atentar para o constante risco de uma identificação excessiva com os protagonistas das situações das quais participamos, buscando um equilíbrio entre observador e participante, em uma constante reflexão crítica. (OLIVEIRA, R. D. D.; OLIVEIRA, M. D. D., 1981, p. 28);

b) fazer uso (também) de estratégias de entrevista livre, em que se busca estabelecer um diálogo aberto, em que "se amplia a livre expressão da pessoa com quem se conversa; amplia o campo do discurso que passa a incluir não só fatos e opiniões bem delimitadas, mas também devaneios, projetos, impressões, reticências, etc. [...] Muitas vezes, não é unicamente aquilo que é dito explicitamente que é significativo" (OLIVEIRA, R. D. 


\section{D.; OLIVEIRA, M. D. D., 1981, p. 29).}

Questões de pesquisa

Essa tese dedica-se inicialmente a apresentar um mapeamento da EAP, com ênfase em seus desafios e práticas pedagógicas, visando uma possível sistematização do que parece ser um conjunto de percepções, práticas e trajetórias compartilhadas.

Nossa principal hipótese de trabalho é que esses elementos compartilhados se consolidam como um campo (a Educação Popular Audiovisual) em que se estabelecem diálogos mais ou menos explícitos com o campo correlato da educação em geral, em especial com o subcampo que identificamos como das educações alternativas e democráticas - tanto em suas teorias como em suas experiências práticas.

Para investigar tal hipótese, estabelecemos uma sequência de questões específicas, que guiam o desenvolvimento desta tese:

a) a experiência da EAP é abrangente? Quão abrangente?;

b) que problemas os projetos se propõem a resolver? Por que autores ou métodos se orientam para fazê-lo?;

c) como o fazem?;

d) que problemas efetivamente resolvem?;

e) quando e como alcançam o melhor de seu potencial pedagógico?

\section{Corpus}

O corpus dessa tese é composto por experiências de Educação Audiovisual Popular, a partir do ponto de vista de diferentes agentes desse circuito. Mas o que compreendemos como uma experiência de Educação Audiovisual Popular?

Em resumo, compreendemos como uma experiência de Educação Audiovisual Popular uma atividade educativa gratuita, promovida por uma entidade ou agremiação 
informal de pessoas, voltada, possivelmente entre outros objetivos, ao ensino dos meios de realização audiovisual.

Diversas entidades e agremiações realizaram ou realizam atividades que se enquadram nessa descrição, desde o início do século 20. No entanto, nos interessa especialmente verificar as características específicas desenvolvidas desde a popularização das câmeras filmadoras digitais, especialmente na metade da década de 1990, e sua imediata apropriação por entidades do terceiro setor já atuantes, ou especialmente criadas a partir desse período.

Sendo assim, as entidades ${ }^{6}$ que constituem o corpus, necessariamente:

a) promovem (ou promoveram) $\operatorname{projeto~}^{7}(\mathrm{~s})$ de ensino audiovisual de acesso gratuito;

b) possuem atuação comprovada na área da Educação Audiovisual Popular entre 1990 e 2009. Mesmo que as atividades tenham começado em data anterior $^{8}$;

c) promovem atividades - prioritárias, mas não exclusivamente - voltadas a: jovens moradores de bairros urbanos localizados em bolsões de pobreza, ou grupos socialmente marginalizados, tais como comunidades indígenas e quilombolas, portadores de necessidades especiais, frequentadores de Centros Psicossociais (CAPS e CAPS/AD), dentre outros.

As entidades foram mapeadas inicialmente durante o processo de construção do banco de dados da seção KinoOikos Formação do Olhar do Festival Internacional de Curtas-Metragens de São Paulo, organizado pela Associação Cultural Kinoforum. O banco de dados é composto por dados fundamentais, como objetivos gerais das entidades e projetos e informações completas sobre os vídeos inscritos no Festival. A partir dele, foi possível contatar as entidades para que participassem das diferentes etapas do mapeamento realizado. Todas as informações coletadas na pesquisa retro-

\footnotetext{
${ }^{6}$ Utilizaremos o termo entidades para nos referirmos às instituições ou agremiações informais que, exclusivamente, ou dentre suas atividades, promovem os projetos de Educação Audiovisual Popular pesquisados.

${ }^{7}$ Utilizaremos o termo projetos para nos referirmos especificamente às atividades de Educação Audiovisual Popular ocorridas nas entidades. No caso de entidades que possuem outras atividades, essa diferenciação é fundamental. No caso de entidades cujo objetivo central é a Educação Audiovisual Popular, muitas vezes, o nome da entidade já é o próprio nome do projeto. Nesses casos, o nome do projeto será considerado idêntico ao da entidade.

${ }^{8}$ Alguns projetos pioneiros e contemporâneos à ABVP prosseguiram em percursos exemplares - caso da Cineduc e do projeto Vídeo nas Aldeias, em funcionamento até hoje -, e também compõem o corpus da pesquisa. Mas, a maior parte dos projetos abordados nessa pesquisa surgiu nos últimos quinze anos, entre 1995 e 2009.
} 
alimentaram este banco, e serão disponibilizadas publicamente nos sites do Festival e da ECA/USP.

Conteúdo - questionários e entrevistas

A parte não presencial do levantamento foi realizada através da aplicação online de quatro questionários. Trata-se de um sistema de questionários virtuais que podem ser acessados, preenchidos e enviados a partir de um blog - método bastante prático, que não exige pessoas para aplicá-los, o que tornaria a empreitada inviável. Os questionários encontram-se nos Anexos desta tese (Anexo H, I, J e L), e continuam disponíveis nos respectivos blogs, na Internet (endereços nos mesmos Anexos).

O primeiro questionário tinha como objetivo principal detectar a abrangência da experiência da Educação Audiovisual Popular no Brasil nas duas últimas décadas. Os itens do questionário que mais se integram aos objetivos dessa tese dizem respeito às propostas metodológicas das entidades/projetos, autores que mais os inspiram, bem como as principais características efetivamente pedagógicas de sua atuação. No entanto, diversos outros elementos, que não influenciaram diretamente a redação final deste texto, foram inseridos neste questionário, tendo em vista a confluência de elementos que tornava a situação extremamente oportuna para o estabelecimento de um panorama geral. Sendo assim, optei por incluir também itens que buscam construir um perfil geral das entidades, e que podem, por diferentes vias, servir a outros pesquisadores e, especialmente, àqueles que desenvolvem políticas públicas para o setor.

Os outros três questionários, aplicados da mesma forma num momento posterior, tiveram como objetivo diversificar os pontos de vista que tínhamos sobre as entidades e projetos levantados a partir da percepção de coordenadores, educadores, alunos e ex-alunos. Estes questionários tematizam prioritariamente assuntos relevantes para as questões de pesquisa que movem esta tese.

\section{Questionário Principal}


O conteúdo do questionário principal foi desenvolvido com vistas ao levantamento de informações gerais e relevantes para uma avaliação da abrangência e expressividade da Educação Audiovisual Popular no Brasil, a partir de 1990, bem como das características estruturais básicas de suas práticas pedagógicas, a saber:

Dados sobre a entidade promotora: informações de contato (endereço, telefones e emails); perfil (Público, privado, etc.); Ano de Fundação e, quando aplicável, de extinção da entidade; Objetivos gerais da entidade.

Dados sobre os projetos de ensino audiovisual: ano de implantação e, quando aplicável, de extinção; objetivos gerais e específicos; perfil dos cursos (carga horária, duração da formação, oferta de certificação); financiamento; metodologia (método, referências pedagógicas, instâncias de participação); estatísticas (alunos formados e inseridos no mercado de trabalho, vídeos produzidos, exibidos em festivais e premiados).

Estes questionários foram preenchidos por um profissional designado livremente por cada entidade, com maior participação de coordenadores, educadores, gestores e produtores.

Ao final deste mapeamento foram identificadas 113 entidades, formais ou informais, cuja atuação foi documentada ou comprovada de maneira considerada satisfatória:

70 entidades responderam o questionário $(61,9 \%)$;

43 entidades que participaram de festivais voltados a esse público, ou possuem atuação reconhecida (foram citados em pesquisas, por exemplo), mas não foram localizadas ou não responderam ao questionário $(38,1 \%)$.

\section{Amostra A (70 entidades)}

Os questionários preenchidos pelas 70 entidades constituem a principal amostra desta pesquisa, a Amostra A, que contém respostas qualitativas (textuais) e 
quantitativas (múltipla escolha, numéricas, etc.).

Amostra B1 (Amostra A - 70 Entidades + 4 entidades: total de 74 entidades)

Sobre 4 entidades citadas por outros pesquisadores foi possível aferir também dados gerais como cidade, estado, ano de fundação e de início do projeto de ensino audiovisual. Este subconjunto de 69 entidades é analisado exclusivamente no que tange a esses dados.

Amostra B2 (Amostra B - 74 Entidades + as demais 39 entidades identificadas: total de 113 entidades)

Sobre as 39 entidades integradas nessa amostra, julgou-se apropriado confirmar a cidade e estado de realização. Para isso, se empreendeu uma pesquisa, em parceria com a equipe da Kinoforum, via internet e telefone.

Dessa forma, definiu-se a Amostra B2, com 113 entidades, exclusivamente no que tange às informações citadas (cidade, estado). Julgamos fundamental realizar esse empreendimento para que, ao menos demograficamente e em características de simples aferição, possamos ter uma visão bastante abrangente.

Segunda etapa - Entrevistas e Questionários adicionais

A segunda etapa do mapeamento, constituída por entrevistas presenciais e questionários adicionais, e essencialmente qualitativa, teve como objetivo compreender com maior profundidade e clareza as estratégias pedagógicas utilizadas pelas equipes que atuam nas entidades. 
O principal critério utilizado na escolha das entidades foi a identificação em seu discurso e trajetória - a partir do que pudemos depreender da participação de seus agentes e alunos no Festival de Curtas, bem como de seus websites e publicações - de elementos que apontassem para um ou mais dos seguintes aspectos:

a) compromisso central, efetivo e contínuo com a Educação Audiovisual Popular, descartando entidades em que o projeto de Educação Audiovisual Popular é excessivamente secundário com relação a outro objetivo maior;

b) desenvolvimento intuitivo ou sistematizado de uma metodologia original de ensino audiovisual popular;

c) qualidade artística dos vídeos, atestada pela participação em festivais e exibições públicas;

d) notória qualidade na formação de jovens autônomos e empreendedores, atestada pelo surgimento de coletivos independentes e outras formas de associação por seus alunos e ex-alunos.

Essa segunda etapa ocorreu presencial e virtualmente.

21 entrevistas, com 30 diferentes profissionais e alunos, foram realizadas presencialmente, e registradas em vídeo, nas cidades de Rio de Janeiro, Belo Horizonte e São Paulo, entre fevereiro e agosto de 2009.

Foram entrevistados gestores, coordenadores, educadores, alunos e ex-alunos das iniciativas escolhidas para esta etapa da pesquisa.

A decisão sobre quais agentes, dentre os citados, falariam por cada entidade foi tomada sempre em diálogo com os representantes das mesmas. Em todos os casos houve anuência e interesse total das entidades e seus representantes em participar da pesquisa, e os representantes selecionados falaram em nome das mesmas. E a seleção foi sempre pautada pelo potencial que a contribuição que cada agente teria para a almejada sistematização pedagógica que esta tese assumidamente buscava. Em alguns casos, a decisão foi tomada levando em conta a relevância e originalidade do trabalho 
realizado por determinados profissionais e alunos, e em alguns casos esparsos, em decorrência das limitações de tempo de um ou outro profissional.

Realizei também duas entrevistas coletivas, com grupos de alunos (no Cinema Nosso, no Rio de Janeiro) e de educadores (na Oficina de Imagens, em Belo Horizonte).

A estratégia de abordagem utilizada nas entrevistas previa apresentar apenas temáticas amplas, citadas de maneira breve, de modo que os entrevistados se expressassem livremente, evitando interromper o "livre pensar" dos entrevistados. Esperava-se que a partir do tema inicial, diversos outros temas que integravam o roteiro fossem naturalmente citados por eles - o que ocorreu efetivamente. As entrevistas foram, em geral, um tanto longas, durando entre 60 e 180 minutos cada uma.

Ainda assim, foi impossível garantir que todos os entrevistados abordassem todos os temas que compunham o nosso "roteiro invisível", dada sua amplitude e extensão. Mas o recorte feito pelos entrevistados em geral respeitava, justamente, os temas que lhes eram mais presentes e urgentes. E a última pergunta, que era mais uma sugestão, pedia para que eles citassem temas gerais em que considerassem a experiência da iniciativa exemplar em algum aspecto, garantindo também a inclusão de temas que desejassem destacar.

De maneira geral, foram abordados os seguintes temas:

Entrevistas com educadores e coordenadores: percurso do profissional (como se tornou educador/coordenador audiovisual e por que); orientação pedagógica de sua própria atuação; referências pedagógico-didáticas (a priori ou a posteriori); profissionalização (objetivo ou efeito colateral); ensino de processo criativo; limites éticos entre equipe e alunos; limites de interferência em gravações e edições (assessoria versus coautoria); importância da alimentação; participação dos alunos nas decisões; exemplos de práticas e jogos didáticos realizados. 
Entrevistas com gestores e administradores: percurso do profissional (como se tornou gestor de projeto de ensino audiovisual e por que); orientação pedagógica de sua própria atuação; profissionalização (objetivo ou efeito colateral); seleção da equipe de educadores e orientação geral da entidade; limites éticos entre equipe e alunos; importância da alimentação; participação dos alunos nas decisões.

Entrevistas com alunos: percurso até chegar à oficina; principais dificuldades pessoais quando entrou; principais conquistas a partir dela; percepção quanto ao nível de participação pessoal nas decisões da entidade; exemplos de aulas e aprendizados marcantes; expectativas de futuro.

\section{Amostra C - Entrevistados presenciais}

Foram entrevistados presencialmente:

Três Gestores: Zita Carvalhosa (Oficinas Kinoforum-SP), Danielle Fiabane (Instituto Criar de TV, Cinema e Novas Mídias-SP) e Chico Serra (TV Morrinho-RJ)

Oito Coordenadores: Igor Barradas (Abaeté/Humano Mar-RJ), Márcio Blanco (Observatório de Favelas-RJ), Miriam Machado (Cinema Nosso-RJ), Roberto Robalinho (Alice, Prepara o gato!-RJ), Alexia Melo (AIC-MG), Paula Kimo (Oficina de Imagens-MG), César Maurício (Favela é isso aí-MG), Hélio Passos (BH Cidadania-MG) e Cirlan (Tv Morrinho-RJ).

Sete Educadores: Gui Mohallem (Instituto Criar/ ELCV e outros-SP); Josinaldo Medeiros (Abaeté/ Cidadela-RJ); Rodrigo Francisco Corrêa de Oliveira, Victor Dias dos Santos, Fernando Luiz Ferreira Rabelo, Juliana Celestino (Oficina de Imagens-MG); Clebin Santos (AIC-MG).

Onze Alunos: Zé Luis, Marcos Coelho (Alice, prepara o gato!-RJ); Esteves, Nicholas (Morrinho-RJ); Tamiris Lourenço, Diogo Felipe, Carolina Mirati, Taís Cristina, Ivo César da Silva de Oliveira, André Tavares, Maria Teresa (Cinema 
Nosso-RJ).

Questionários virtuais adicionais qualitativos - Amostras D, E e F

Um contato presencial, bem como o imenso volume de transcrições, tornava a ampliação do corpus de entrevistas presenciais impraticável; E no primeiro questionário (geral), havia pouco espaço para que cada participante imprimisse sua visão pessoal - uma vez que a preocupação, no caso, era a percepção do discurso oficial da entidade.

Buscamos, portanto, abrir um espaço maior para que todos pudessem, mesmo que através da Internet, construir um discurso próprio.

Sendo assim, foram desenvolvidos também três diferentes questionários de entrevista, contendo questões similares às utilizadas nas entrevistas presenciais, voltados a Educadores (Corpus D), Coordenadores (Corpus E) e alunos/ex-alunos (Corpus F); e, como citado, estes questionários foram disponibilizados para as equipes das entidades em blogs na Internet. O link para cada questionário foi enviado pela própria entidade aos profissionais, de acordo com o perfil de relacionamento.

No caso específico do questionário para alunos e ex-alunos, buscamos detectar como se dá a percepção de sua própria formação em uma amostra de ex-alunos de diferentes projetos.

Os questionários encontram-se no anexo desta tese, bem como a lista de entrevistados virtuais (11 educadores, 7 coordenadores e 82 alunos).

Amostra G-Registros e documentos pessoais

Um número pequeno de registros e documentos pessoais relativos à minha atuação na área foi aos dados dessa tese, destacando-se um relato informal, planos de curso e relatórios elaborados por educadores e coordenadores aos quais tive acesso e 
os quais fui autorizada a publicar.

Os documentos referem-se especialmente a atividades desenvolvidas em dois $\operatorname{projetos}^{9}$ nos quais desenvolvi e implantei algumas estratégias isoladas inspiradas em aspectos e metodologias que problematizo nesta tese, também com o objetivo de realizar pequenas experiências piloto que, em alguma medida, dialogassem com essa pesquisa. Tais estratégias realizadas nas experiências piloto serão mencionadas e analisadas seguindo o mesmo critério adotado com relação às demais.

\section{Forma de análise dos resultados}

A definição de uma estratégia para análise dos resultados foi o maior desafio desta metodologia. Ao amplo volume das informações coletadas, incluindo sobre as experiências piloto citadas, somou-se uma década de percepções pessoais, redundando numa quantidade realmente desproporcional de informações e reflexões sobre o tema.

Se a variedade de metodologias empregadas permite uma visão panorâmica da experiência, enriquecendo a análise em pontos de vista e diversidade das colaborações, as entrevistas presenciais tendem a trazer o frescor resultante da troca que se estabelece presencialmente. Já os questionários virtuais, em sua impessoalidade, tendem a homogeneizar nuances, mas contam com o benefício de uma objetividade que não se alcança nas entrevistas.

As informações foram submetidas a dois tipos distintos de análise. A inicial, qualitativa, sugeriu referências bibliográficas interessantes. A secundária, qualitativa e quantitativa, foi realizada em paralelo à revisão bibliográfica e redação dos primeiros capítulos - com o auxílio de estatísticas, tabulações e, na reta final, de assistentes de pesquisa.

\footnotetext{
${ }^{9}$ Os projetos Oficinas Tela Brasil, promovido pela Buriti Filmes, e a Escola Livre de Cinema e Vídeo, que é uma ação da Prefeitura de Santo André.
} 
$\mathrm{Na}$ análise final, convertida em texto, se buscou cruzar as informações coletadas a partir dos diferentes instrumentos, agregando a contribuição reflexiva, que é o objetivo desta tese: quando e como as experiências da EAP alcançam o melhor de seu potencial pedagógico?

\section{Capítulos}

O Capítulo 1 apresenta um histórico do problema, a partir da contribuição de pesquisadores e autores que estabeleceram pesquisas de fronteira. Investigamos um panorama que apresenta a seguinte sequência (uma espécie de genealogia da Educação Audiovisual Popular): do ensino técnico de cinema, vinculado à indústria nascente aos cineclubes; destes ao ensino universitário, às outras ondas cineclubistas e ao vídeo militante; do movimento do vídeo popular às TVs de Rua; e o surgimento da Educação Audiovisual Popular.

O Capítulo 2 apresenta um perfil da experiência da Educação Audiovisual Popular, a partir dos dados coletados pelo questionário sobre as entidades, analisando as informações necessárias para construção da resposta às primeiras questões de pesquisa: seria a experiência abrangente? Quão abrangente? Que problemas se propõe a resolver? Por que autores ou métodos se orienta para fazê-lo?

O Capítulo 3 apresenta um panorama de conceitos, autores e experiências pedagógicas sugeridos pelos discursos das entidades, no Capítulo 2, de modo a estabelecer: de que forma as entidades lidam com tais métodos e referências no cotidiano? Quais as características mais destacadas do autor e métodos mais citados que são evidentes nas práticas da EAP? Que outras experiências compartilham desafios e soluções com a EAP?

O capítulo 4 apresenta uma síntese dos dados levantados durante a pesquisa, em um panorama de estratégias pedagógicas e de gestão pelos quais os diversos projetos pesquisados promovem a EAP. Na primeira parte, apresento as principais estratégias pedagógicas utilizadas pelas entidades no que tange à gestão, ao espaço, à adesão dos alunos e sua interação com a equipe pedagógica. Na segunda, apresento 
três perfis de oficinas a partir dos critérios de duração e carga horária. Analiso na segunda parte desse capítulo uma síntese das práticas pedagógicas em cada um desses perfis.

Por fim, o Capítulo 5 apresenta uma verificação dos problemas que a experiência efetivamente resolve, a partir de resultados mensuráveis, como a participação em festivais e exibição na televisão; da inserção profissional dos exalunos; e não mensuráveis, como a visão dos alunos sobre o próprio processo de aprendizado. 


\section{Do ensino livre e universitário à Educação Audiovisual Popular - (EAP)}

Este capítulo procura apresentar uma breve genealogia da Educação Audiovisual Popular (EAP), especialmente pelo viés dos desafios pedagógicos enfrentados em cada etapa: um breve histórico do movimento cineclubista, que em suas primeiras ondas (até os anos 1950) deu consistência e formou quadros para o surgimento das primeiras universidades de cinema, e nas seguintes (mais políticas e "subversivas", nos anos 1960, 70 e 80) deu fôlego ao movimento que viria a se afirmar como o Vídeo Popular; e a emergência da Educação Audiovisual Popular, desdobramento histórico do vídeo popular e foco deste trabalho.

A experiência da Educação Audiovisual Popular é então apresentada de maneira panorâmica: a evolução dos termos pelos quais a experiência se apresentava e era citada pela mídia e pelos próprios agentes; e o surgimento de festivais, políticas públicas para o setor, instâncias políticas e de reflexão, ao longo dos anos 2000.

\subsection{Do ensino livre ao universitário}

Apesar de ter sido anunciado que em 2010 o primeiro curso de licenciatura em ensino audiovisual do país será lançado na Universidade Federal Fluminense, no Rio de Janeiro, não há ainda no um suporte em pesquisa em âmbito nacional adequado para apoiar o educador audiovisual na construção de suas abordagens pedagógicas e de conteúdo. E há poucas pesquisas acadêmicas voltadas à reflexão sobre o ensino de audiovisual, em cursos livres, técnicos ou universitários. Os aspectos efetivamente didáticos e pedagógicos seguem praticamente "secretos".

Algumas exceções iniciaram uma mudança nesse panorama. "A Formação em Cinema em Instituições de Ensino Superior Brasileiras”, dissertação de mestrado 
defendida em 2004, por Luciana Rodrigues Silva, na Escola de Comunicações e Artes da USP (ECA), sob orientação da Prof. Dra. Maria Dora Mourão, realiza uma odisséia pela história do ensino de cinema (livre e superior) no Brasil e em alguns outros países, em uma extensiva e detalhada descrição das trajetórias históricas e cinematográficas, bem como da estruturação legal das principais escolas, docentes e alunos.

A dissertação de Silva nos trouxe fôlego para investir o tempo devido no momento histórico, que é o objeto da tese: um presente estendido de apenas 20 anos, entre 1990 e 2009. Mas, contando com o devido suporte da pesquisa da autora, empreenderemos uma breve jornada por essa trajetória do ensino de cinema no Brasil - que nos conduzirá também a outros precursores da Educação Audiovisual Popular.

Existe um senso comum que dita que só o tempo, no próprio mercado cinematográfico, pode dar conta de formar seus profissionais. Há também um mito: poucas cinematografias efetivamente relevantes teriam suas origens na universidade. Silva defende e demonstra, "na contramão dos profissionais que consideram que cinema não se aprende na escola, que grandes movimentos no Brasil e internacionais surgiram ou foram reforçados dentro das escolas e cursos de cinema”. (SILVA, 2004, p. 7)

A necessidade de se legitimar a relevância da existência da formação universitária em cinema, para o desenvolvimento do próprio cinema, denota o quão movediço é o campo. Mas, o que a história demonstra é que, desde que há cinema, as pessoas vêm buscando criar meios de formar novos profissionais para atuar nessa indústria.

Do ponto de vista histórico, o ensino de cinema tem em seus primórdios um vínculo profundo com essa indústria, então nascente. A primeira iniciativa de estudos cinematográficos do mundo surgiu em 1919 na União Soviética, o GIK Gosudarstvenyi Institut Kinematographic (Instituto de Cinematografia Estatal da União). Inaugurada praticamente sem equipamentos, era uma escola em que inicialmente apenas se simulava a prática do cinema. 
Das oficinas de montagem do GIK saíram alguns dos mais prolíficos textos sobre a montagem cinematográfica, por professores como Lev Kuleshov, que tinha um laboratório de experimentação, e Vsevolod Pudovkin. Segundo Silva, "a experimentação era o mote para professores e estudantes. Desprovidos de meios, os disponíveis eram objetos de improvisos e experiências, e a teoria tinha, necessariamente, que se sobrepor à prática. Os alunos aprendiam roteiro, direção e interpretação em frente às câmeras inexistentes" (Ibidem, p. 9-10)

Já em seus primórdios, o ensino de cinema demonstrava ser o ambiente perfeito para a criatividade pedagógica e a criação de laboratórios vivos, com alunos sendo literalmente cobaias de seus professores pouco mais experientes do que eles como ocorre com muita frequência na $\mathrm{EAP}^{10}$.

No Brasil, a mais notória experiência pioneira de ensino de cinema teria sido a Escola de Artes Cinematográficas Azurri, que, segundo Maria Rita Galvão, teria entre seus alunos "futuros atores, diretores, cinematografistas, laboratoristas, cavadores". Até 1922, era a única escola da cidade de São Paulo; formando quadros para a expansão do cinema no país e dando força à cavação ${ }^{11}$, iria perdurar até 1924. (GALVÃO, $1975^{12}$ )

Mas seria apenas com ascensão dos cineclubes - notadamente a partir da fundação do Chaplin Club em 1928 no Rio de Janeiro e do Clube de Cinema de São Paulo, em 1940, na Faculdade de Filosofia da USP - que começaria a se formar no Brasil uma efetiva cultura de reflexão sobre o fazer cinematográfico, o que implicaria posteriormente de forma decisiva para a criação dos primeiros cursos universitários do país.

\footnotetext{
${ }^{10}$ Em uma entidade carioca em atividade desde 2004, a “Alice, prepara o gato!", (cuja experiência abordaremos em detalhe mais adiante), o processo de montagem dos vídeos dos alunos ocorre de maneira análoga - ocorre, digamos, em frente a uma ilha de edição inexistente. Os alunos do projeto, adultos e sem interesse algum por tecnologia, gravam os vídeos e concebem a montagem conceitualmente, a partir de imagens e signos, criando sentido entre elas abstratamente. E a parte técnica-prática é apenas executada pelos educadores, jovens cineastas pela Universidade Federal Fluminense.

${ }^{11}$ A "cavação" foi um movimento pioneiro do cinema brasileiro, em que se realizava produtos inicialmente desprezados pelo "grande cinema". Segundo Fernão Ramos, a cavação era um espaço "menosprezado" da sobrevivência no cinema, e que cobria "o documentário de encomenda, a propaganda e o ensino em pequenas escolas de cinema". (RAMOS, 2000, p. 177)

12 (apud SILVA, 2004, p. 44)
} 
Lúcio Henrique Monteiro Rodder e Aguiar defendeu, em 2005, na UFF, uma dissertação intitulada "Olhar Arrevesado: estudo de caso sobre a produção audiovisual de localidade na cidade do Rio de Janeiro" ${ }^{\prime 3}$. No panorama histórico que traça, Aguiar analisa a produção resultante de experiências de Educação Audiovisual Popular no Rio de Janeiro, entre 1993 e 2004, a que ele se refere como "Produção de Localidade", especialmente a partir de seus antecedentes históricos-políticos, dentre eles, o movimento cineclubista e o Vídeo Popular.

Segundo Aguiar, "o Chaplin Club (1928-1930) é tido como primeiro cineclube brasileiro de expressão. Voltado à exibição da vanguarda europeia, embarca na discussão da pureza do cinema mudo, proposta por seu patrono, combate o som e a cor na sétima arte. Sua equipe constitui-se de intelectuais conservadores do porte de Octávio de Farias, Vinicius de Moraes e Plínio Sussekind". (AGUIAR, 2005, p. 98)

O Clube de Cinema de São Paulo seguia a mesma tendência de abordagem estética. Era "liderado por Francisco Luís de Almeida Salles, e foi logo fechado pelo Departamento de Imprensa e Propaganda, cujas atividades retornam em 1946, com a participação de Paulo Emílio Salles Gomes, constituindo o núcleo inicial da Cinemateca Brasileira (1954)". (AGUIAR, 2005, p. 98)

Essa fase da história dos cineclubes no Brasil é caracterizada por Aguiar como "fase cinéfila", e teria durado entre 1928 e 1958, sempre associada a clubes de cinema.

Além do cineclubismo, outra fonte importante de referências pedagógicas e reflexivas para o desenvolvimento de uma cultura cinematográfica e de ensino no país foi o Institut des Hautes Études Cinématographiques, o IDHEC, escola francesa em que estudaram diretores como Louis Malle e Alain Resnais - e que recebeu também alguns jovens brasileiros, que no retorno ao Brasil reaqueciam os debates - e universidades nascentes, com suas influências modernas européias. Estudaram no IDHEC intelectuais como Salles Gomes, diretores como Joaquim Pedro, Rodolfo 
Nanni, Anselmo Duarte e Ruy Guerra, dentre muitos outros. Como observa Silva:

É Possível afirmar, assim, que o IDHEC tem uma grande ligação com a atividade de ensino de cinema no Brasil, já que muitos dos supra mencionados estiveram, ou estão, presentes nas principais instituições formadoras de pesquisadores e realizadores do país. [...] Ruy Guerra figura como diretor do curso de cinema, de tecnólogo, da Universidade Gama Filho; Eduardo Coutinho estudou no Seminário de Cinema do MASP [...]. (SILVA, 2004, p. 33)

É justamente durante as décadas de 1950 e 60, quando as vanguardas cinematográficas europeias brilhavam, que estes jovens críticos e cineastas brasileiros retornavam de formações nas universidades da Europa, assumindo, aqui, um papel decisivo na criação e desenvolvimento da maior parte dos primeiros cursos regulares, universidades e cinematografias do Brasil.

Rudá de Andrade liderou, em 1966, a criação da Escola de Comunicações Artes da USP (ECA), e admite ter se utilizado de sua experiência no Centro Sperimentale de Cinematografia ${ }^{14}$ de Roma para administrar a escola:

A minha parte era mais administrativa, funcional. Por acaso, eu tinha feito um curso universitário de cinema em Roma, me formei lá, então tinha experiência de Escola de Cinema; o Paulo Emílio, nessa época, já estava ligado à Universidade de Brasília, se não me engano, eu ficava mais em São Paulo e ele em Brasília, naquele embrião de formação da escola de Brasília. (ANDRADE em entrevista a SILVA, p. 213)

É importante também destacar o papel central e constante do intelectual Paulo Emílio Salles Gomes, que integrava diversas das experiências pioneiras, desde o Clube de Cinema de São Paulo até a fundação das Escolas São Luiz e da ECA/USP.

Além disso, percebe-se uma constante histórica, de interpenetração entre os modelos de curso, uns influenciando o surgimento de outros, em uma sequência de eventos decisivos:

1. o surgimento do pioneiro Seminário de Cinema do MASP, que esteve ativo entre 1949 a 1959. Entre seus alunos, Rodolfo Nanni (ex-aluno do

\footnotetext{
${ }^{14}$ Andrade refere-se ao curso de Cinema do Centro Sperimentale de Cinematografia, fundado em 1935, pelo qual passaram cineastas como Michelangelo Antonioni e os brasileiros Joaquim Pedro de Andrade e Luis Sérgio Person. (www.csc.it)
} 
IDHEC) e Máximo Barro, que posteriormente viriam a dirigir a fundação do curso de Cinema da FAAP, em 1976;

2. a fundação da Escola Superior de Cinema da Universidade Católica de Minas Gerais, que esteve ativa entre 1962 e 1970 - uma experiência pioneira e de ênfase bastante teórica. $\mathrm{O}$ destaque fica por conta de sua aula inaugural, ministrada pelo cineasta Humberto Mauro;

3. a criação do curso de cinema da UnB (Universidade de Brasília) em 1963, que entre este ano e 1964 teve como professores Paulo Emílio Salles Gomes, Nelson Pereira dos Santos, Jean Claude Bernardet, Dib Lutfi, e muitos outros;

4. a criação, em 1963, em Salvador, na Universidade Federal da Bahia, por Walter da Silveira, do Grupo Experimental de Cinema (GEC), que teve entre seus alunos André Luiz de Oliveira, José Frazão e José Umberto;

5. o curso promovido em 1962 pelo Itamaraty-Unesco no MAM do Rio de Janeiro, com o realizador sueco Arne Sucksdorff, considerado decisivo para o desenvolvimento ulterior do Cinema Novo, e que tinha dentre os alunos Maurice Capovilla e Vladimir Herzog;

6. a fundação em 1965 da Escola Superior de Cinema São Luiz, que tinha entre seus professores Salles Gomes, Person, Tonacci, Mário Chamie, Décio Pignatari e Anatol Rosenfeld. Segundo Silva, "o encontro dos então estudantes Carlos Reichembach, Carlos Alberto Ebert e João Callegaro na São Luiz com o professor Tonacci e com “não-alunos”, como Rogério Sganzerla, Jairo Ferreira, José Mojica Marins e Ozualdo Candeias, pode ser considerado o embrião do cinema marginal, que germinou na Rua do Triunfo, Boca do Lixo da capital paulista, no final dos anos [19]60" (SILVA, 2004, p. 55);

7. a fundação da Escola de Comunicações Culturais da USP em 1966. O curso de Cinema da USP foi criado por um grupo de "egressos do cineclubismo", como Paulo Emílio Salles Gomes, Décio Almeida Prado, Luís de Almeida Salles e Antonio Cândido. Atuavam, na fase inicial do curso da ECA, professores como Maurice Capovilla, Jean Claude Bernardet, Roberto Santos e Maria Rita Galvão; Ismail Xavier (atualmente aposentado) e Marília Franco (professora atual da ECA) foram alunos 
dessa primeira turma. (Ibidem, p. 214);

8. a criação do Curso de Cinema do MAM do Rio de Janeiro, que durou até a década de 1970, e teve como alunos Arthur Omar e Silvio Tendler;

9. o surgimento do Curso de Cinema da UFF, em 1971, como resultado de uma articulação de Nelson Pereira dos Santos, que buscava refletir o projeto do curso de Cinema implantado na UnB (Universidade de Brasília);

É preciso citar também a emergência de duas importantes escolas cinematográficas na America Latina:

10. a Universidad Nacional Del Litoral del Instituto de Cinematografía de Santa Fé, na Argentina, em 1957, que teve como alunos, visitantes e colaboradores diversos cineastas e professores brasileiros, como Glauber Rocha, Maurice Capovilla e Vladimir Herzog;

11. e a EICTV (Escola Internacional de Cinema e Televisão), fundada em San Antonio de Los Baños, Cuba, em 1986, e em atividade até hoje. A EICTV tinha como motivação inicial "impulsionar o progresso dos meios audiovisuais na América Latina e no Caribe, além da África e Ásia, regiões afetadas pelo subdesenvolvimento e dependência imperialistas, o que lhe rendeu a alcunha de "escuela de três Mundos" (Ibidem, 69).

Dentre os principais desafios pedagógicos enfrentados na ocasião, apontados pelos diferentes entrevistados por Silva, destacamos dois aspectos: uma tendência de ênfase no chamado "Cinema Moderno", fruto, em alguma medida, do vínculo de seus profissionais com o cineclubismo; e a subsequente questão do suposto antagonismo entre abordagens pedagógicas e de repertório voltadas à autoria/expressão e à profissionalização/mercado. São conflitos visíveis em diferentes entrevistas concedidas a Silva, e aparecem com igual destaque nos discursos da EAP.

Sobre a orientação inicial do curso da USP, Rudá de Andrade comentou: "Eu tinha essa formação documental, o negócio do neo-realismo, a coisa de Santa Fé; eu 
Marília Franco, estudante da primeira turma, e que se tornaria professora da universidade futuramente, também percebia essa orientação com clareza:

Seguíamos dois grandes eixos cinematográficos que dominavam o fim dos anos [19]60, início dos anos 70: o Cinema Novo brasileiro e a Nouvelle Vague francesa. A gente respirava Godard o tempo todo, e Resnais, aquela coisa toda. Os cinema-novistas, óbvio, eram nossos grandes mestres. De certa forma, todos queria ser Glauber. É, não sei, acho que até hoje as pessoas continuam querendo ser Glauber, menos como cineasta, mais como pessoa. (apud Silva, 2004).

Esse vínculo era também claramente percebido pelos alunos. Miguel Freire, aluno dos primeiros cursos de cinema da UnB, também comenta o fato, destacando a importância dos cineclubes em sua formação:

\begin{abstract}
Sem dúvida, o movimento do cinema novo com todas as suas preocupações ideológicas...Os movimentos cineclubistas sempre tiveram por trás de cada curso. Eu acho que você tem nisso a raiz dos cursos. Posso pensar de novo na minha experiência, o curso de Brasília, na segunda etapa, nasce dentro de um cineclube - que era uma escola à parte -, onde assistíamos todos os filmes da Nouvelle Vague e do Neo Realismo Italiano, e tínhamos uma Mostra (apud Silva, 2004).
\end{abstract}

Mas, quais são as efetivas implicações de uma formação em que o Cinema Moderno possui destaque - no mínimo pela constante exibição de filmes, o interesse e a paixão de seus professores pelo tema?

A ampliação do repertório cultural é uma das mais centrais contribuições da universidade à formação de seus alunos. No que tange especificamente ao ensino de Cinema, muitos cursos costumam apresentar panoramas históricos, organizados em diferentes e sucessivos semestres, em que se detecta o objetivo de apresentar todas as principais cinematografias.

Mas, partindo tanto das leituras quanto de minha interpretação, nota-se que as universidades dão conta, de fato, de apresentar panoramas parciais, se não no sentido cronológico, no sentido da paixão. Todas as escolhas são subjetivas, por fim: as cinematografias consideradas essenciais, dentro destas a dos cineastas, e na obra destes, dos filmes e trechos a serem exibidos. Impossível existir uma ambição de 
totalidade. O título de um livro de Jean Luc Godard expressa essa mesma percepção, de que seria impossível contar a história do Cinema, e sim apenas mais "Uma história do Cinema".

É também em diálogo com essas pequenas e grandes escolhas feitas no âmbito do repertório que surgem as estratégias pedagógicas que visam despertar o aprendizado das diferentes técnicas envolvidas no "fazer" audiovisual, bem como de seus diferentes elementos de linguagem. E é nesse momento que escolhas decisivas são tomadas para os alunos.

A realização audiovisual voltada ao mercado comercial audiovisual (publicidade, cinema, televisão) muitas vezes prevê uma incorporação de signos típica da modernidade, incluindo aí signos do Cinema Moderno. Mas, estruturalmente, o mercado profissional de audiovisual inspira-se em um paradigma em que, raramente, um profissional pode expressar-se de maneira autoral - como era o caso dos cineastas modernos.

Carlos Augusto Calil, ex-aluno e professor da ECA, atual Secretário Municipal de Cultura de São Paulo, durante muitos anos diretor da Cinemateca Brasileira e depositário da obra fílmica de Glauber Rocha, costuma dizer que não acredita que seja possível dissociar o Cinema de seu caráter industrial, e sugere que a graduação seja um espaço de formação com uma ênfase mais profissionalizante:

Acho que o curso tem que ter uma característica híbrida; acadêmico onde pode ser acadêmico, na história, na teoria, e em outros setores que são puramente técnicos, ele tem que se abrir para profissionais [...]. A visão que eu tenho do curso da ECA? Eu acho que a graduação tem que ter uma ênfase profissionalizante, o curso de pós-graduação tem que ter uma ênfase em estudos históricos (apud SILVA, 2002.)

No entanto, na mão oposta, as estratégias pedagógicas dos cursos de Cinema ou Audiovisual em geral ainda prevêem justamente mais espaços de autoria e reflexão acadêmica do que de formação técnica-profissionalizante voltada ao mercado buscando-se talvez que o aluno aproveite o espaço da universidade para experimentar, o que será extremamente raro no mercado. Como provoca Franco: 
mas, ainda assim, a formação dentro da escola é muito forte; por outro lado, eu fico me perguntando, aqui é só uma divagação: se no âmbito da formação de um cineasta, a autoria não é um eixo fundamental, porque é, de fato, o momento em que o aluno tem que ter absoluta liberdade de se encontrar como realizador. $\mathrm{Na}$ vida profissional, depois, ele vai seguir outro rumo, ele vai ser mais comercial. (apud SILVA, 2004)

Esse exercício constante da autoria é uma decorrência clara da influência do Cinema Moderno, ou como se referiu Franco, de Autor. Pratica-se a autoria de muitas maneiras, e os aprendizados técnicos e de mercado acabam, muitas vezes e ironicamente, ocorrendo de maneira análoga ao mercado: dada a ênfase em estudos e repertório moderno, é na prática de tais linguagens que os alunos, de fato, acabam aprendendo os aspectos técnicos.

Exercícios de apropriação e recombinação criativas de um discurso préexistente, como a citação, a paródia e o pastiche, são muito comuns. Propõe-se, por exemplo, a realização de vídeos que ensejem releituras de gêneros clássicos, estratégia muito comum no Cinema Moderno e que, inevitavelmente, aproxima os alunos de tais referências. Estas, por sua vez, possuem implicações estéticas, políticas e também no âmbito logístico-financeiro: os cinemas modernos, ao contrário do opulento cinema comercial, primam pela simplicidade de produção, típica do período pós-guerra em que se consolidou.

É, por fim, no tenso equilíbrio entre esse espaço de expressão e autoria, e a necessidade central de que os alunos entrem no mercado, que se estruturam os cursos universitários.

A formação universitária em cinema tem sido um constante ponto de origem para educadores audiovisuais de São Paulo e Rio de Janeiro. Projetos como as Oficinas Kinoforum, as Oficinas Tela Brasil, o Instituto Criar e a Escola Livre de Cinema e Vídeo de Santo André, o Ateliê de Vídeo do Instituto Acaia, do estado de SP, e “Alice, Prepara o gato!", Oficinas Cinemaneiro e da CUFA, do Rio de Janeiro, por exemplo, tiveram grande parte de suas equipes formadas por egressos de escolas de cinema.

A escolha do repertório exibido para os jovens é feita, muitas vezes, em 
sintonia com a formação em "Cinemas Modernos" que os alunos tiveram nessas universidades. E se nestas, o viés Cinema Moderno possuía um antecedente histórico, configurando uma escolha essencialmente estética e política, no caso da EAP, agregam-se a estes dois elementos fundamentais: o desejo, muitas vezes um tanto passional, de apresentar aos alunos cinematografias radicais, desconhecidas e em geral inacessíveis a eles; e de, possivelmente, inspirar a realização de produções que optem, igualmente, pela não convencionalidade estética - tantas vezes vista no audiovisual clássico/de mercado.

Essas escolhas podem, também, implicar na realização de vídeos mais adequados às reais possibilidades de realização de cada projeto. Referindo-se às experiências recentes da EAP, o pesquisador Hernani Heffner provoca, vendo talvez certo oportunismo na ênfase dada nelas aos cinemas "alternativos", e que eventualmente redunda na reapropriação crítica ou ingênua de tais gêneros e linguagens: "muitos núcleos de formação procuraram "propostas alternativas", enxergando na história do Cinema momentos de subversão dos padrões e das limitações técnicas e orçamentárias". (HEFFNER, s.d., p. 3)

Os egressos da ECA e de outros cursos de cinema que tornaram-se educadores e coordenadores em geral reproduzem seus próprios universos de interesse na seleção dos filmes e cinematografias abordadas nas aulas de história do cinema. A duração especialmente nos projetos curtos ( $80 \mathrm{~h}$ até 1 mês de aula) - não permite absolutamente que se faça uma visão sequer panorâmica da história do cinema e de sua linguagem. O que ocorre, em geral, é uma visão particular. Como veremos em maior detalhe no capítulo 4.

É importante destacar que em entidades da EAP, cujos profissionais possuem formação em outras áreas, como em Comunicação Comunitária, muitas vezes ocorrem situações análogas - em que se busca, por exemplo, exibir experiências de televisão alternativas em busca de referências que inspirem os alunos a produzir com esse viés de maneira mais criativa. 


\subsection{Do vídeo popular à EAP}

Além do surgimento dos cursos universitários de cinema, outro acontecimento seminal diretamente relacionado com a expansão das oficinas de vídeo nas duas últimas décadas é o movimento do Vídeo Popular, que surge no final da década de 1970.

Em meio aos movimentos cineclubista e militante, em plena ditadura militar, o Vídeo Popular emerge como forma de diversificar as estratégias de comunicação das então crescentes organizações sociais. Seu processo de expansão decorre essencialmente de uma decisão política de realizadores ligados a tais movimentos, que veem no vídeo uma potente ferramenta de divulgação de suas ideias, como comenta Alvarenga:

Assim como, no final da década de 1960, havia sido cunhada a expressão 'vídeo militante' para nomear um tipo de trabalho que se opunha à produção massiva identificada na televisão, na década de 1970, o vídeo passa a ser entendido também como instrumento de 'contra-informação'. (ALVARENGA, 2004, p. 46)

Clarice Maria Castro de Alvarenga defendeu sua dissertação de mestrado, intitulada "Vídeo e Experimentação Social: um estudo sobre o vídeo comunitário no Brasil”, na UNICAMP (Universidade de Campinas) em 2004.

Partindo do panorama traçado por Aguiar e Alvarenga, e especialmente do relato em "primeira mão" de Luis Fernando Santoro, participante ativo do movimento e autor do livro A imagem nas mãos - O Vídeo Popular no Brasil, é possível vislumbrar um caminho razoavelmente claro conduzindo o Vídeo Popular à Educação Audiovisual Popular.

Segundo Santoro, o conceito de Vídeo Popular abrange:

A produção de programas de vídeo por grupos ligados diretamente a movimentos populares, como por exemplo, os sindicatos e associações de moradores e movimentos dos Sem-Terra. 
A produção de programas de vídeo por instituições ligadas aos movimentos populares para assessoria e colaboração regular, como grupos da Igreja, a FASE, o IBASE, centros de defesa dos direitos humanos, entre outros.

A produção de programas de vídeo por grupos independentes dos movimentos populares, que por iniciativa própria elaboraram sob a ótica e a partir dos interesses e necessidades desses movimentos, que são por fim seu público mais importante.

O processo de produção de programas de vídeo, com a participação direta de grupos populares em sua concepção, elaboração e distribuição, inclusive apropriando-se dos equipamentos de vídeo.

Tudo isso é, para nós, o vídeo popular. Uma definição abrangente, que tem como referência primordial a prática do uso do vídeo pelos movimentos populares, o volume dessa produção, o seu teor, os grupos que são responsáveis por ela e a exibição de programas comprometidos com a realidade social". (SANTORO, 1989, p. 60-1)

As chamadas câmeras abertas e as exibições públicas em espaços inesperados eram algumas das características típicas das muitas TVs de Rua que integravam o movimento, nas quais a ênfase das propostas recaía sobre a recepção coletiva:

Em geral, são produzidos vídeos com alguma participação de uma dada comunidade, e que, em seguida, são transmitidos para a própria comunidade em espaços abertos (praças públicas) ou fechados (postos de saúde, creches, escolas, centros comunitários, associações de bairro, sindicatos, ginásios esportivos e hospitais). A exibição de TV de Rua pode seguir-se da chamada "câmera aberta", técnica que consiste em estimular as pessoas a debater sobre o conteúdo visto a partir da transmissão desse debate no mesmo suporte em que foi exibido o vídeo popular produzido. A prática da câmera aberta enfatiza a multiplicidade inerente à recepção e a simultaneidade dos processos de emissão e recepção. (ALVARENGA, 2004, p. 151)

Entre 1980 e 1989, dezenas de projetos distintos realizaram experiências pioneiras análogas e integraram o movimento de vídeo popular, tais como: a TV dos Trabalhadores, em São Bernardo; o Centro de Documentação e Memória Popular, de Natal; A TV Bixiga e a TV dos Bancários, em SP; A Lilith Vídeo, em Brasília; A Enúgbárijo, no Rio de Janeiro; A TV Viva, em Olinda; o CECIP, Centro de Criação da Imagem Popular, em Nova Iguaçu; o Vídeo Memória, em Curitiba; e o CEMI, Centro de Comunicação de São Miguel, na periferia da capital paulista; o CTI, Centro de Trabalho Indigenista, em São Paulo; dentre outros. (SANTORO, 1989, p. 79-80)

No entanto, apesar da grande abrangência e do volume de produções oriundos da experiência coletiva, havia uma contradição intrínseca ao Vídeo Popular: um desejo de que a câmera estivesse nas mãos das pessoas para que elas próprias pudessem tomar imagens do mundo (ALVARENGA, 2004, p. 45-6), sem que, 
contudo, se oferecesse meios para que elas se apropriassem da linguagem, como já alertava o próprio Santoro "o domínio da linguagem do vídeo não é, nem de longe, um domínio apenas de técnica, dos movimentos de câmera, mas a compreensão de inúmeros outros aspectos, onde o assunto, os objetos, as falas, as pessoas que estão sendo gravadas são o mais importante”. (SANTORO, 1989, p. 105)

Valter Filé relembra, com humor, que as organizações se apressaram em comprar equipamentos e gravar infindáveis horas de reuniões, passeatas e assembleias, bradando que as gravações iriam "entrar para a história”: "Bom, talvez história fosse o nome de alguns armários, que era para onde iam a maioria destes materiais, sem que jamais fossem utilizados para alguma coisa" (FILÉ, 2000, p. 3)

A ABVP (Associação Brasileira de Vídeo Popular) foi fundada pouco tempo após o I Encontro Nacional de Grupos Produtores de Vídeo no Movimento Popular, realizado em São Bernardo do Campo, em 1984. E surge, dentre outros motivos, para tentar superar esses desafios. Segundo Santoro, ABVP foi fundada

\begin{abstract}
com o objetivo de dar sequiência à esperada ação de organização, de representação política dos grupos, de busca de financiamentos para a compra de equipamentos de pós-produção para uso coletivo, de facilitar a organização de mostras, o contato entre diferentes grupos para coprodução, e de oferecer cursos e seminários. (SANTORO, 1989, p. 68)
\end{abstract}

Em 1986, no III Encontro Nacional de Grupos de Vídeo Popular, em São Paulo, a ABVP já percebia a necessidade de realizar atividades de capacitação ainda mais abrangentes que as experimentadas até então, e desenvolveu propostas que visavam uma formação teórica e de repertório, bem como metodologias de produção e exibição e aperfeiçoamento técnico-operacional. (SANTORO, 1989, p. 71)

O fato de os próprios realizadores estarem fascinados com a descoberta da ferramenta também contribuía para afastar os integrantes dos movimentos sociais, aos quais por fim se destinavam as práticas. Como observa Henrique Luis Pereira Oliveira, em sua dissertação:

Diversas ações foram levadas a efeito para que efetivamente os movimentos populares participassem da maneira mais ampla possível do processo de produção de vídeos. Todavia, um dos traços que singularizou o 
vídeo popular foi o fato de que esta produção correspondeu a um momento em que as pessoas que atuavam junto aos movimentos sociais (comunicadores, educadores etc.) tiveram, elas mesmas, o acesso aos meios de produção audiovisuais. (apud ALVARENGA, p. 51)

Ou seja, nesta primeira fase do Vídeo Popular, criar e executar estratégias de ensino para ampliar a participação dos projetos sociais era justamente um dos maiores desafios. E nas análises e estudos que pudemos verificar, foi possível depreender pouco sobre as estratégias pedagógicas surgidas nesse contexto.

No entanto, o Vídeo Popular não foi um movimento homogêneo, e em 1995, ano em que as contradições intrínsecas ao movimento ainda levariam à extinção da ABVP, foi realizada pela própria entidade uma Oficina Latino-Americana de Capacitação em TV/ Vídeo Comunitários em Belo Horizonte, com a coordenação da TV Sala de Espera (TVSE). No processo da oficina se desenvolveu outro projeto pioneiro: A TV Beira Linha (TVBL), em que "durante duas semanas pessoas de vários projetos, de diversos locais do Brasil, trabalharam numa comunidade, produzindo programas sobre seu cotidiano e convivendo com a recepção destes programas, junto com os moradores"15 - o que já apontava para a verdadeira potencialidade das estratégias de comunicação comunitária ${ }^{16}$, e demonstrava um caminho efetivo para a superação dos desafios vividos pelo Vídeo Popular dos primeiros anos: a formação técnica aliada à participação.

\subsection{Educação Audiovisual Popular *}

Neste subcapítulo, começamos a utilizar os dados coletados na pesquisa de campo, como respostas a questionários, estatísticas, gráficos e entrevistas.

\subsubsection{PRIMEIROS CONCEITOS - UMA VISÃO ETIMOLÓGICA DA}

\section{EXPERIÊNCIA}

\footnotetext{
15 (FILÉ, 2000, p. 4)

${ }^{16}$ (FILÉ, 2000, p. 4)
} 
Aguiar e Alvarenga dedicaram-se a investigar um universo de experiências que é compartilhado, parcialmente, por esta pesquisa. Estes autores, ao isolar e descrever as características das experiências, estabeleceram as bases para uma possível definição das fronteiras do campo, ao qual se optou por chamar nesta pesquisa, sob um viés pedagógico, Educação Audiovisual Popular (EAP).

Alvarenga trabalhou com um corpus nacional; realizou entrevistas e analisou a prática do vídeo comunitário contemporâneo. "Investigamos a metodologia de uso do vídeo e a trajetória de dez grupos - três localizados em São Paulo, três no Rio de Janeiro, três em Belo Horizonte e um em Olinda". (ALVARENGA, 2004, p. 11). A autora classificou seu corpus em quatro eixos principais, que incluem projetos que integraram também o vídeo popular.

Atuação Indigenista: Vídeo nas Aldeias (SP/PE); Anthares Multimeios (SP). A Produção de Vídeo Curta-metragem: Oficinas Kinoforum (SP); BH Cidadania (BH). Por uma Pedagogia das Imagens: Gens Serviços Educacionais; Oficina de Imagens; Núcleo de Educação e Comunicação Comunitária. Transmissão Televisiva: TV de Rua e TV a Cabo; Associação Imagem Comunitária; TV Favela; TV 100\% Comunidade.

Esta opção sugere que a autora abordou as experiências a partir de certas similaridades entre elas, especialmente as que dizem respeito ao tipo de público-alvo (no caso da atuação indigenista) e aos diferentes objetivos contemplados (nos demais casos). Essa classificação favorece a análise e dá conta de apresentar um panorama das principais vertentes de projetos em atividade no biênio 2003/2004.

A escolha do conceito vídeo comunitário contemporâneo para designar o objeto de pesquisa denota outro aspecto importante da abordagem da autora: a ênfase - ainda que um pouco mais etimológica do que prática, pois ela aborda outros aspectos também - no produto das experiências, ou seja, os vídeos que elas geram.

Já Aguiar trabalhou com um corpus de entidades cariocas, entrevistando e analisando a atuação delas, e se dedicou, especialmente, a observar o papel dos 
instrutores dos cursos enquanto formadores de multiplicadores; e a investigar "se a apropriação dos meios de produção pela população de localidade implica em desenvolver estética própria”. Como ele comenta na introdução:

\begin{abstract}
Na cidade do Rio de Janeiro convivem em torno de 6 núcleos com produção regular em vídeo ou em película. Esse material, exibido em Mostras e Festivais Nacionais, constitui o universo analítico desta Monografia, composto por 50 títulos em curta e média-metragem cariocas confeccionados entre 1993 e 2004. (AGUIAR, 2005)
\end{abstract}

Ele abordou, por fim, a experiência de nove entidades ${ }^{17}$ : Núcleo de Cinema do Grupo "Nós do Morro"; Oficinas Cinemaneiro; Centro de Estudos e Ações Solidárias da Maré (CESM); Central Única das Favelas (CUFA); TV Morrinho; Núcleo de Educação e Comunicação Comunitária da Faculdade Hélio Alonso (NECC/FACHA); Empresa de Multimeios da Prefeitura do Rio de Janeiro (MULTIRIO); As Oficinas da Rocinha; Nós do Cinema.

O autor, apesar de mencionar dentre seus objetivos a análise dos processos de ensino-aprendizagem, refere-se à experiência como vídeo de localidade ou vídeo comunitário, alinhando-se a Alvarenga e mais uma vez sugerindo, etimologicamente, uma abordagem sob a perspectiva da produção.

Rafaela Lima aborda em seu artigo um conjunto amplo que inclui experiências de TVs de Rua, e outras um pouco posteriores como as TVs Sala de Espera e BeiraLinha, fazendo uso do termo TV comunitária,

[...] termo aqui utilizado para designar experimentações televisivas realizadas junto a comunidades definidas geográfica e/ou tematicamente, que têm como proposta básica promover o acesso da comunidade envolvida aos processos de planejamento, produção e veiculação dos programas. Tais experiências diferenciam-se da TV de massa, portanto, pela abrangência limitada e, sobretudo, pela proposta de promoção do acesso comunitário aos processos de produção. [FONTE ?]

A abordagem sob esse viés alinha-se, nos três casos citados, também à forma como os jovens formados pelos projetos buscam caracterizar a própria produção, especialmente em coletivos e núcleos independentes - e sem englobar no termo as

\footnotetext{
${ }^{17}$ Em comum entre as duas pesquisas, há apenas o NECC/FACHA.
} 
experiências pedagógicas pelas quais passaram. Por exemplo, já se convencionou utilizar, em Fóruns Populares de Audiovisual do estado de São Paulo, denominações como cinema comunitário jovem, cinema de quebrada e, mais recentemente, vídeo popular.

Esta pesquisa se diferencia de Aguiar e Alvarenga ao abordar as experiências especialmente sob o viés de suas propostas pedagógicas, bem como das implicações e potenciais contribuições mútuas entre os campos da educação e do audiovisual - o que se evidencia no termo escolhido, a experiência, ou as experiências da Educação Audiovisual Popular. Ou seja, a experiência compartilhada de entidades e projetos que promovem gratuitamente, e para públicos historicamente excluídos socialmente, o ensino dos meios de realização audiovisual.

\subsubsection{FRONTEIRAS HISTÓRICAS}

Como vimos, o universo que convencionamos nesta tese chamar de Educação Audiovisual Popular não é um campo tal que esteja pré-definido na literatura, nem que seja naturalmente evidente. Analogamente, suas fronteiras temporais, estabelecidas pelos diferentes pesquisadores, também não são uma unanimidade.

Alvarenga localiza o início da prática do Vídeo Comunitário na segunda metade da década de 1990, sugerindo como marco histórico a extinção da ABVP em 1995, momento em que "vários projetos que vinham da fase do vídeo popular começam a abdicar da câmera, transferindo-a para as mãos dos grupos sociais. Para que a câmera migrasse para a mão de pessoas que nunca antes haviam manipulado um equipamento de vídeo foi preciso criar oficinas" (ALVARENGA, 2004, p. 98)

Já Aguiar aborda uma década de experiências, de 1993 a 2004, compreendendo em um mesmo corpus entidades de perfis históricos diversos, e cujo produto da prática ele se refere como vídeo comunitário ou de localidade.

Sabe-se também que no início da década de 1990 ainda havia projetos 
vinculados ao vídeo popular e às TVs comunitárias em atividade. Mas, ao longo da década, diversas entidades vinculadas à ABVP, ou que atuavam sob seu paradigma, foram extintas ou tiveram seus objetivos transformados. E surgiu ao menos uma dezena de entidades ${ }^{18}$, que pouco a pouco foram implantando seus projetos de educação audiovisual com objetivos já bastante distintos ou em processo de diferenciação do vídeo popular que as precedera.

Ou seja, enquanto se estabelecia e amadurecia o novo modelo pedagógico e institucional da EAP, que detalharemos adiante, os dois modelos coexistiram por alguns anos. E apenas algumas entidades e profissionais egressos do vídeo popular - e suas fronteiras - conseguiram sobreviver a essa transição. Dentre eles:

a) a Cineduc, no Rio de Janeiro, fundada em 1970, e que continua em atividade até hoje, com o objetivo de "promover a reflexão sobre as linguagens audiovisuais com o público infanto-juvenil e educadores, formais e informais, a fim de contribuir no processo educativo transformador, através do desenvolvimento da consciência crítica e da expressão criativa". (Questionário Cineduc, 2009) A trajetória da entidade é única: atuou e "sobreviveu" a momentos históricos tão distintos como a ditadura militar, a redemocratização do país e a popularização das câmeras filmadoras digitais, tendo formado, segundo suas estimativas, mais de 1000 alunos, que produziram, em quarenta anos de atuação, mais de 250 vídeos;

b) o Vídeo nas Aldeias (VNA), fundado em 1987 pelo antropólogo Vincent Carelli, que também integrara a pioneira experiência do CTI em São Paulo. Segundo as respostas dadas ao questionário, "o objetivo do projeto foi, desde o início, apoiar as lutas dos povos indígenas para fortalecer suas identidades e seus patrimônios territoriais e culturais, por meio de recursos audiovisuais e de uma produção compartilhada com os povos indígenas

\footnotetext{
${ }^{18}$ Faculdades Integradas Hélio Afonso, e seu Núcleo de Educação e Comunicação Comunitária (NECC), implantado em 1992; A Bem TV, que implanta o Projeto Olho Vivo também em 1992; A Empresa de Multimeios da Prefeitura do Rio de Janeiro, que implanta seu projeto em 1993; As Oficinas da Rocinha, desenvolvidas especialmente entre 1993 e 1995; Associação Cala-BocaJá-Morreu (1996) e O Instituto Garatuja (1996); O "Nós do Morro", que fundado em 1986 lança suas atividade audiovisuais em 1996; a Anthares Multimeios, que tem seu projeto lançado em 1997, tendo sido fundada em 1993; a Associação Novolhar (1997), a Associação Projeto Perifa (1999) e a Imagem na Ação - núcleo de desenvolvimento de projetos de comunicação e cidadania / TV Pinel (1999).
} 
com os quais o VNA trabalha". Em 33 anos de atividade, a entidade construiu um sólido percurso, realizando oficinas e promovendo também a produção de festivais e redes de televisão em todo o mundo. (Questionário, 2009);

c) profissionais ligados aos projetos TV Sala de Espera (TVSE) e TV Beira Linha, de Belo Horizonte, que fundaram em 1997 a hoje proeminente entidade da EAP: a Associação Imagem Comunitária, que promove, dentre outros, a Rede Jovem de Cidadania, projeto que, em alguma medida, revisita e revigora as propostas das TVs Comunitárias e de Rua - com conteúdo integralmente produzido por jovens das diferentes comunidades da cidade, e que semanalmente é exibido em canal público de sinal aberto (Rede Minas).

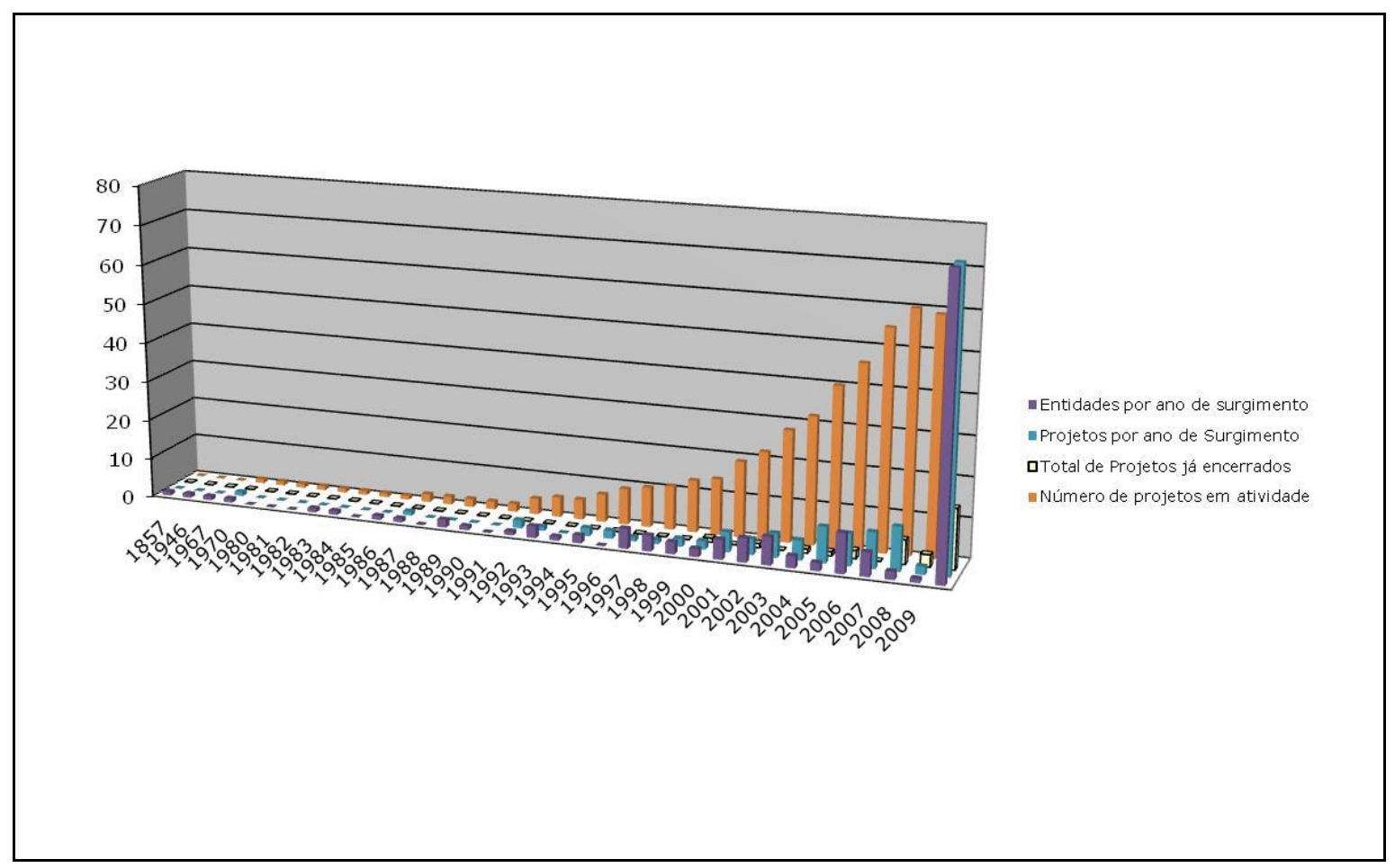

Fonte: Questionário Entidades

Gráfico 1 - Evolução das entidades e projetos no tempo

Como se observa no gráfico acima, é especialmente a partir dos anos 2000 que ocorre um boom de novas entidades e projetos - em sincronia histórica com a retomada do Cinema Nacional, que atinge seu ápice com sucessos de bilheteria como “Cidade de Deus" (2002) e "Carandiru" (2003) -, trazendo a exclusão social para a 
pauta do dia. Década em que, também, Lula chega ao poder, assumindo a formação cultural e a disseminação da cultura livre digital como bandeiras no campo da política cultural, e implantando políticas públicas, como o Projeto Cultura Viva, que promovem especialmente projetos culturais de pequeno porte, das mais diversas áreas, incluindo Audiovisual.

\subsubsection{ANOS 2000 - UMA VISÃO EVOLUTIVA E POLÍTICA}

É sem dúvida a partir dos anos 2000 que há uma maior documentação das experiências em Educação Audiovisual Popular - por isso este período entra como foco desta tese. Desde 2005, o âmbito de debates e de Fóruns Populares ligados ao desenvolvimento de políticas públicas começa a tomar conta da pauta.

Como é praticamente impossível apresentar um panorama que, de fato, seja imparcial, buscamos nesse subcapítulo relatar uma história desses anos, iniciando em 2002 - a partir da visão certamente subjetiva, porém, constante, que tive ao participar e depois coordenar a Formação do Olhar do Festival de Curtas de São Paulo (entre 2002 e 2008); ao participar do Fórum Cinema de Quebrada (entre 2005 e 2006); ao supervisionar a equipe da Mostra Cinema de Quebrada (realizada em outubro de 2005) e ao idealizar e gerir o site KinoOikos.

Foi também a partir dessa experiência na linha de frente que surgiu a motivação para esta tese. Uma revisão dos termos e dos temas abordados a cada ano talvez demonstre também um pouco da evolução histórica da experiência e seus desafios.

Em 2002, o tema de destaque do Festival Internacional de Curtas-Metragens de São Paulo foi intitulado "Formação do Olhar". O tema fora inspirado no fato de que, no ano anterior, o Festival promovera um ciclo de 4 Oficinas de Vídeo (o projeto Oficinas Kinoforum de Realização Audiovisual) em comunidades da periferia da cidade de São Paulo, e os vídeos, então produzidos, necessitavam de um espaço para exibição. Havia notícias de que outros projetos semelhantes estavam em andamento, 
além de iniciativas antigas e de sucesso, como o projeto Vídeo nas Aldeias e os Ateliers Varan. E o tema inspirava discussão.

A coordenadora Lizandra Almeida fez uma extensa pesquisa, e diversos projetos foram convidados a exibir seus vídeos e integrar o debate. Durante todo o período do festival, os vídeos foram exibidos, e ocorreram três debates especiais, com a mediação do crítico e pesquisador Jean Claude Bernardet. Estive presente nessa primeira edição - em que foi exibido publicamente (pela primeira vez) o curtametragem realizado por alunos meus de 14 anos da escola do Jaraguá - e participei de uma mesa de debates, cujo foco temático foi essencialmente a dualidade "processo versus resultado", um conflito que de fato nunca deixou de nos acompanhar.

Durante esse primeiro fórum não existia um termo único para definir a experiência de realizar Oficinas de Ensino de Cinema ou Audiovisual, e tampouco uma urgência por defini-lo. Alguns projetos se auto-definiam Oficinas de Realização Audiovisual, outros Oficinas de Produção de Vídeos, Oficina de Vídeo Popular, etc. À experiência que coordenei chamávamos simplesmente de Oficina de Cinema, e o filme produzido pelos alunos foi captado em $16 \mathrm{~mm}$.

Em 2003, a seção Formação do Olhar, que foi destaque especial do ano anterior, tornou-se uma mostra permanente do Festival de Curtas de São Paulo. Nesse ano, participaram 15 projetos/entidades, 36 vídeos foram exibidos e os debates, mais uma vez, contaram com a mediação de Jean Claude Bernardet. Dessa vez, um dos encontros foi protagonizado pelos coordenadores, como no ano anterior, e outro por realizadores (alunos e ex-alunos dos projetos). Um dos principais temas de debates neste ano foi a urgência e a emergência da realização de oficinas de aperfeiçoamento - como o módulo II das Oficinas Kinoforum (Okin), implantado a partir de 2002 e, desde então, realizado anualmente.

Naquele ano se iniciava minha atuação como educadora das Oficinas Kinoforum; participei do debate de alunos e ex-alunos como representante do projeto, sentada na plateia. Para mim, o que houve de mais marcante nesse debate foi a resposta que Jean Claude Bernardet deu a uma pergunta minha. Questionei se não 
seria interessante organizarmos alguma espécie de Fórum, espaço de encontro mais sistemático que nos permitisse refletir sobre a experiência e pensar sobre seu futuro. Bernardet foi bastante contrário à minha proposta, resumidamente dizendo algo como: “a única coisa que esse movimento não precisava era se institucionalizar". Essa resposta faria muito sentido para mim anos depois, como veremos logo adiante.

O ano seguinte, 2004, foi bastante significativo para esse universo, com o surgimento de um novo festival dedicado a uma parte desse público e o lançamento primeira edição de um Projeto de Lei, no município de São Paulo, perfeitamente adequado ao estágio de desenvolvimento dos grupos independentes em formação. Também foi o ano de início de políticas como o Revelando os Brasis e, principalmente, os Pontos de Cultura, por meio da Secretaria de Programas e Projetos Culturais, do Ministério da Cultura.

Foi também em 2004 que assumi a coordenação da sessão Formação do Olhar, concomitantemente à minha atuação nas Oficinas Kinoforum, como colaboradora pedagógica. Neste ano, foram exibidos vídeos realizados em 22 diferentes projetos de formação.

No Fórum da Formação do Olhar de 2004, uma das mesas foi composta por cinco pesquisadores (Esther Hamburger, José Gatti, Fernão Ramos, Mauricio Hirata e Miriam Celeste) que, a nosso convite, elaboraram também artigos sob encomenda para um tablóide - distribuído gratuitamente durante o $15^{\circ}$ Festival Internacional de Curtas Metragens de São Paulo (Conforme o anexo 1). Dentre outros temas, os convidados destacaram a urgência da criação de cursos de licenciatura que formem profissionais para o ensino audiovisual - o que finalmente começa a surgir, com o lançamento da licenciatura da UFF.

O segundo dia de debates contou com uma novidade: em decorrência do surgimento, nos últimos anos, de 6 coletivos audiovisuais formados por ex-alunos, organizamos um evento a que chamamos "Fórum de Projetos". Neste momento, estes coletivos eram chamados mais comumente "núcleos independentes", e foram formados por ex-participantes de projetos de São Paulo (das Oficinas Kinoforum) e 
do Rio de Janeiro (Cinemaneiro e Cinema Nosso).

Assim, no Fórum de Projetos, ao longo de uma tarde, 6 coletivos apresentaram sua história e projetos futuros ao público: MUCCA (Mudança com Conhecimento, Cinema e Arte), NERAMA (Núcleo de Estudos e Realização Audiovisual do Monte Azul), Arroz Feijão Cinema e Vídeo, Filmagens Periféricas, Boca de Filme e Nós do Cinema, que já era uma entidade formal mas ainda tinha um discurso bastante vinculado à produção.

Naquele ano, como no anterior, na proposta se adotou uma terminologia que também se prestava a delimitar os potenciais participantes da seção, e que desde então continuou sendo empregada: "Oficinas gratuitas que utilizem o vídeo como ferramenta de inclusão social".

Em 2004, o Instituto Marlin Azul e a Galpão Produções lançaram, em Vitória (ES), o Festival de Jovens Realizadores do Mercosul, que refletia o aumento dessa produção e sua necessidade de difusão. Pelo próprio nome do festival, fica claro que o projeto tem um recorte etário, e isto, por vezes, gerou críticas de realizadores oriundos de oficinas cujos participantes tinham mais que 24 anos - idade-limite adotada pela ONU para caracterizar o público jovem, e que foi também a utilizada pelo Festival. Desde então, ele realiza-se anualmente, e tem como objetivos: "dar visibilidade à produção jovem; promover a inclusão e a formação audiovisuais; estimular o intercâmbio entre jovens realizadores e instituições; promover a reflexão acerca do conteúdo audiovisual produzido por jovens e destinado a esse público; e incentivar, por meio da troca de experiências, os aprimoramentos dos projetos, levando à reflexão crítica das ações desenvolvidas".

No final do ano de 2004 foi lançada, em São Paulo, a primeira edição do VAI ${ }^{19}$ - Programa para a Valorização de Iniciativas Culturais. Segundo o blog do projeto:

O Programa para a Valorização de Iniciativas Culturais - VAI, foi criado pela Lei 1354 e regulamentado pelo decreto 43823/2003, com a finalidade de apoiar financeiramente, por meio de subsídio, atividades artístico-

\footnotetext{
${ }^{19}$ Lei de autoria do vereador Nabil Bonduki acessível em http://leivai.blogspot.com/ e disponível na íntegra no Anexo L.
} 
culturais, principalmente de jovens de baixa renda e de regiões do Município desprovidas de recursos e equipamentos culturais. $\mathrm{O}$ grande diferencial deste edital é a possibilidade de inscrição como pessoa física, o que o tornou tão adequado aos núcleos independentes surgidos recentemente.

Nesta edição, foram aceitos projetos de até $\mathrm{R} \$ 15.000,00$, contando com 650 inscritos, sendo 66 selecionados (54 Pessoas Físicas e 12 Jurídicas). Dentre os contemplados, o coletivo Filmagens Periféricas, de Negro JC, Kelly Regina e Claudio Nunes (o "Tio Pac") formado por ex-alunos das Oficinas Kinoforum.

O projeto Revelando os Brasis, lançado também em 2004, é dirigido a moradores de municípios brasileiros de até 20 mil habitantes. O programa é uma parceria da Secretaria do Audiovisual do Ministério da Cultura com o Instituto Marlin Azul, com patrocínio da Petrobrás, através da Lei Rouanet.

A primeira edição do Revelando os Brasis recebeu 417 inscrições. O projeto selecionou 40 histórias, e promoveu uma oficina de formação em roteiro, direção, produção, fotografia e câmera, som, edição, direção de arte, mobilização e direitos autorais para a realização delas.

Programas compostos por esses vídeos, com 15 minutos de duração, são exibidos em um circuito que passa por cada um dos municípios das propostas selecionadas e pelas capitais dos estados participantes. Em seu primeiro ano, o Circuito Itinerante do Revelando os Brasis rodou $17.114 \mathrm{~km}$, entre 40 municípios brasileiros e mais 21 capitais. Os vídeos transformaram-se também em uma série de televisão, exibida pelo Canal Futura. A produção foi reunida em um DVD, que vem sendo distribuído gratuitamente para bibliotecas, secretarias de cultura e instituições culturais - além de circular em festivais nacionais e internacionais.

O projeto Pontos de Cultura é a principal ação do Programa Cultura Viva ${ }^{20}$, do Ministério da Cultura, idealizado e implantado na gestão do ministro Gilberto Gil no Ministério da Cultura, com origem fortemente ligada a Célio Turino, um de seus

\footnotetext{
${ }^{20}$ Fontes: http://www.cultura.gov.br/site/2010/02/08/pontos-de-cultura-no-exterior/ [é indicado incluir data e hora de consulta eu inventaria]

http://www.cultura.gov.br/site/2009/11/16/minc-e-governo-de-sp-anunciam-300-novos-pontos-de-cultura-no-estado/ http://www2.cultura.gov.br/noticias/noticias_do_minc/index.php? $\mathrm{p}=10193 \&$ more $=1 \& \mathrm{c}=1 \& \mathrm{tb}=1 \& \mathrm{pb}=1$
} 
idealizadores e responsável pela implantação do Programa. Os projetos apoiados são selecionados através de edital público e recebem recursos do Governo Federal, o que possibilita a compra de equipamentos de vídeo, informática, instrumentos, figurinos, assim como a contratação de profissionais para cursos e oficinas, produção de espetáculos e eventos culturais, entre outros. Para Turino, o projeto inverte o perfil usual das políticas públicas, "que têm por método a ideia da carência e da vulnerabilidade. Os Pontos de Cultura são o oposto disto, partem da potência das manifestações culturais das comunidades. Eles trabalham na perspectiva da emancipação, para além da ideia da inclusão social”.

Para o secretário, os Pontos de Cultura inovam não só pelo conceito de política pública, mas também pelo método de atuação, no qual o repasse dos recursos é direcionado à ponta do projeto, evitando que o dinheiro se perca nos meandros da administração pública. Inovador, também, pelo grande alcance que tem junto à comunidade, mesmo que o financiamento tenha um baixo valor (com relação a outros financiamentos, como os privados) com cerca de $\mathrm{R} \$ 60$ mil por ano. Célio Turino toca ainda em questão essencial: "O Ponto de Cultura não é um espaço cultural feito pelo governo para as comunidades. Pelo contrário: são ações desenvolvidas pela comunidade que ganham o reconhecimento do Estado e passam a receber aporte de recursos para aplicar conforme o plano de trabalho composto por eles".

Essa política pública apresentou-se como de extrema importância para quem lida diariamente com a produção e difusão da cultura, e que sempre teve pouco ou nenhum acesso a incentivos e recursos. Foram selecionados no primeiro edital de Pontos de Cultura, em julho de 2004, um total de 262 projetos de todas as áreas da cultura. Para a os projetos de oficinas audiovisuais de sensibilização, formação crítica e mobilizadora, essa política possibilitou consolidar e aprofundar experiências. Neste ano, se tornaram Pontos de Cultura entidades da EAP como Vídeo nas Aldeias (PE), Nós do Morro (RJ), AmFilmesDigitais (AM) e CEDECA Interlagos (SP, que já foi parceiro das Oficinas Kinoforum).

Em 2005 as entidades e coletivos paulistas começaram a se organizar com o objetivo de desenvolver políticas públicas para o setor. Mesmo ano em que foi 
fundado em São Paulo o I Fórum Paulistano de Cinema e Vídeo Comunitário Jovem, na Coordenadoria da Juventude de São Paulo. O Fórum foi inicialmente concebido pela Coordenadoria como um espaço de interlocução entre o poder público e os jovens articulados com esse tipo de produção.

Ao longo desse ano, realizaram-se reuniões semanais, no prédio da Secretaria de Participação e Parceria, no centro de São Paulo, em geral mediadas pelo assessor Renato Musa e com a eventual participação da então coordenadora da Juventude Luciana Guimarães.

Dos longos e intensos debates realizados naquele ano foi possível detectar: a existência de muitas entidades e coletivos realmente interessados e dedicados a construir em conjunto diretrizes para políticas públicas para o setor; e além disso, uma ainda generalizada imaturidade e falta de clareza quanto os diferentes papéis das diferentes instâncias de governo - em alguns momentos, Musa era ingenuamente confundido com uma personificação do "governo", ignorando-se suas reais possibilidades e poderes como assessor.

Os diversos encontros realizados em 2005 foram excepcionalmente importantes por promoverem maior integração entre os variados agentes dessa experiência (coordenadores de OSCIPs, educadores, alunos, ex-alunos), o que acabou por resultar em efetivação, ao longo dos anos subsquentes, de diversas parcerias e, especialmente, a realização da Mostra Cinema de Quebrada (em outubro de 2005, no Centro Cultural São Paulo) e a mais recente formação do Coletivo de Vídeo Popular (em 2008), composto por alguns de seus primeiros integrantes, e extremamente ativo atualmente.

Nos encontros do Fórum, ainda em 2005, definiu-se também um nome, uma importante identidade dessa experiência e produção. O termo "Cinema de Quebrada" imediatamente passou a batizar o Fórum (tornado Fórum Cinema de Quebrada ainda em 2005) e a ser utilizado por todos os seus agentes.

Na edição desse ano (2005), o Festival de Curtas procura dialogar com os 
coletivos formados por ex alunos de Oficinas Audiovisuais: anuncia oficialmente a inclusão na programação da Mostra Formação do Olhar, em seu regulamento - no ano anterior, esse anúncio havia sido feito apenas informalmente.

E no tablóide da Formação do Olhar desse ano, finalmente se anuncia publicamente o resultado deste longo ano de debates entre realizadores, educadores e coordenadores de diferentes projetos da capital paulista: a produção audiovisual resultante de suas experiências era oficialmente batizada por seus próprios agentes como Cinema de Quebrada.

O tablóide de 2005 foi integralmente dedicado às experiências dos coletivos: autores convidados entrevistaram e redigiram artigos sobre eles, que também puderam apresentar a si próprios em coluna própria.

A partir e para além do Fórum Cinema de Quebrada, começava a amadurecer a urgência por políticas públicas que dessem conta dessa expressão. Os convidados dos debates de 2005 tocam muito nesse ponto, e sua expressividade demonstra como o movimento começa a tomar novas dimensões. Estiveram presentes neste ano, dentre outros: os cineastas Laís Bodansky, Tata Amaral, Rodrigo Letier e Marina Weis; os pesquisadores Alexandre Kishimoto e Rose Satiko; o líder de coletivo e representante do Fórum Cinema de Quebrada, Luciano Oliveira; a produtora Assunção Hernandes; a então coordenadora dos CEUS (escolas integradas a aparelhos culturais e esportivos da capital paulista) Juliana Amaral, dentre outros.

Na edição de 2005 do VAI, foram selecionadas 71 propostas, dentre 450 inscritas; sendo, ao menos, 8 projetos na área do audiovisual. Dentre os contemplados, os coletivos independentes Arroz Feijão Cinema e Vídeo, de Vanice Deise e Eder Augusto (ambos ex-alunos das Oficinas Kinoforum), Filmagens Periféricas (este pelo segundo ano consecutivo) e o GEMA - Grupo de Estudo e Mostra Audiovisual (também contando com ex-alunos das Oficinas Kinoforum).

Com relação aos Pontos de Cultura, foram anunciados ${ }^{21}$ em 2005 os 328

\footnotetext{
${ }^{21}$ http://www2.cultura.gov.br/noticias/noticias_do_minc/index.php?p=12057\&more $=1 \& \mathrm{c}=1 \& \mathrm{tb}=1 \& \mathrm{pb}=1$
} 
Pontos de Cultura vencedores dos Editais números 3 e 4 do Programa Cultura Viva. Dentre eles, o projeto “A Margem de Sampa Cultural Heliópolis”, da UNAS.

Em 2006, o foco do tablóide e dos debates mais uma vez foi reflexo direto do aprofundamento das discussões no Fórum Cinema de Quebrada e a diversificação das esferas de atuação desse universo. Em consulta realizada, detectou-se uma necessidade geral de reflexão sobre o que os alunos poderiam fazer, após as oficinas, com o conhecimento audiovisual adquirido: se expressar, se profissionalizar e lutar por políticas públicas para o setor.

O tablóide desse ano focou neste e também em outros temas prementes na ocasião (e que o são ainda hoje), tais como: a possibilidade de inserção do ensino audiovisual nas escolas, a iminente implantação da TV digital e suas implicações, e as novas possibilidades surgidas no campo do ensino audiovisual com as ferramentas então emergentes da web 2.0 - com relação a esse tema, houve também uma palestra com Hermano Vianna, que apresentou o site Overmundo ao público do Festival.

A Mostra Formação do Olhar desse ano exibiu 25 vídeos oriundos de diferentes projetos e núcleos independentes, de 11 estados do país. Um dos debates da seção começa a apontar uma tendência fundamental para o desenvolvimento desta pesquisa, mas ainda na chave de uma possível inserção profissional - muito desejada e solicitada por todos à época. Buscou-se refletir sobre a vocação do ensino audiovisual em promover aprendizados sociais e intelectuais, e a importância de que, no processo formativo, se desse ênfase a tais aprendizados. Estiveram presentes nesta mesa de debates o diretor de programação do Canal Futura, João Alegria, e os educadores-coordenadores Júlio Siqueira, do Nós do Cinema (atual Cinema Nosso), Sávio Leite, do BH Cidadania, e Christian Saghaard, das Oficinas Kinoforum.

O outro debate de 2006, em modelo similar ao que antes chamávamos de Fórum de Projetos, contou com a apresentação de coletivos e núcleos (todos os participantes dos anos anteriores e ainda o Núcleo Jovem, composto por monitores do Instituto Criar, e um grupo de alunos do projeto Vídeo Cultura e Trabalho, da Ação 
Educativa) e um debate entre eles e os convidados sobre as possibilidades de atuação para os jovens a partir das novas mídias. Foram convidados deste debate: Diogo Moysés, da ONG Intervozes, Bete Jaguaribe, do MinC, e a cineasta Kátia Lund - codiretora de "Cidade de Deus".

Na edição de 2006 do VAI foram inscritos 758 projetos e selecionados 62 . Dentre estes, 9 da área audiovisual. Dentre os contemplados: o coletivo Arroz Feijão Cinema e Vídeo, pelo segundo ano consecutivo; o projeto Fabicine, liderado por Wilq Vicente (aluno do VCT, da Ação Educativa e das Oficinas Kinoforum); o projeto Panorama Cinema na Periferia, realizado por Wesley "Peu" Pereira (ex-aluno das Oficinas Kinoforum); o projeto Cinitinerante, do coletivo MUCCA, também formado por ex-alunos das Oficinas Kinoforum; além do projeto do coletivo de animação Graffiti com Pipoca (2006/2007) e o projeto Cine Nos Becos e Vielas (2006/2007).

A segunda edição do Revelando os Brasis, de 2006, selecionou 40 histórias entre as 870 inscrições recebidas, número que dobrou em relação à primeira edição do projeto. A divulgação foi feita por meio da imprensa, rádios locais, Correios, chamadas de TV, contatos com as secretarias de Cultura das cidades com até 20 mil habitantes, além da internet. Houve o esforço para disponibilizar as informações, democratizando o acesso ao projeto e estimulando ao máximo os moradores dos pequenos municípios a contar as suas histórias.

Neste ano, realizou-se o I Encontro de Pontos de Cultura do Estado de São Paulo promovido pelo MinC em Guarulhos e, meses depois, a primeira TEIA 2006 no Ibirapuera/SP, encontro que visa reunir os Pontos de Cultura de todo o país. Nesse ano, um dos projetos selecionados na área audiovisual foi o Ponto de Cultura Bem-tevi, da Associação Cultural Cachuêra!

Em 2007 realizou-se, no Rio de Janeiro, a Mostra Visões Periféricas que, assim como a Formação do Olhar e o Festival de Jovens Realizadores do Mercosul, passou a se dedicar à produção da Educação Audiovisual Popular. Na ocasião foi realizado um fórum sobre os desafios do setor, que contou exclusivamente com a participação de entidades e realizadores presentes do Festival. 
Durante esse fórum, foram realizados grupos de trabalho, e foi redigida uma carta, promovida como "Carta da Maré", que daria conta de fundar um fórum informal, que foi chamado de Fórum de Experiências Populares em Audiovisual (FEPA) - termo que, segundo consta, nunca antes havia sido utilizado, e que visa abarcar tanto entidades formais como coletivos independentes.

O fato de o Fórum, como a elaboração da carta, terem ocorrido em um evento para o qual não foi realizado um convite público nacional - só estavam lá os participantes daquela edição do Festival -, fez com que, em muitas partes do país, houvesse um grande temor inicial de que esse Fórum não se fosse efetivamente representativo.

A Formação do Olhar de 2007 (realizada no mês seguinte) sediou um novo encontro do FEPA, buscando aproximar os presentes no encontro do Rio de Janeiro com uma geração de agentes da Educação Audiovisual Popular que vinham, no Fórum Cinema de Quebrada, nos debates do Festival e em outras instâncias de colaboração, desenvolvendo e debatendo políticas públicas para o setor há diversos anos. Mas a segunda edição do FEPA se deu com conflitos já evidentes entre os participantes do FEPA e os ausentes do encontro "da Maré”.

O encontro foi extremamente ruidoso, e pautado por divergências com relação a um edital que seria brevemente lançado pelo Ministério da Cultura para alunos e egressos de projetos sociais com atuação na área audiovisual. O FEPA havia sido consultado com relação ao conteúdo do edital. Os participantes da primeira edição do FEPA, no Rio de Janeiro, defendiam - de maneira geral, mas não unânime - que o mesmo fosse integralmente dedicado a projetos de realização (curtas-metragens). Outros participantes, alguns deles paulistas e ligados ao antigo Fórum Cinema de Quebrada, defendiam a ampliação do escopo do edital, de forma que pudesse incluir mais ações populares em audiovisual, como projetos de exibição e formação. Isso porque os coletivos independentes atuantes na cidade desenvolviam, em geral, projetos que incluíam todas essas formas de atividade. Essa ideia vinha, sem dúvida, também como reflexo da experiência desses grupos com o VAI paulistano, em que os 
grupos podiam propor projetos diversificados, desde que coubessem nos requisitos de orçamento e cronograma. Não se chegou a termo comum, e posteriormente, pelo que foi apurado na ocasião, as demandas feitas com relação à ampliação do escopo jamais foram transmitidas ao MinC.

Houve também uma forte centralização do discurso dos membros do FEPA no sentido de se promover uma formalização (com criação de CNPJ e definição de líderes eleitos), uma bandeira oficialmente assumida por Márcio Blanco, excoordenador audiovisual do Observatório das Favelas, fundador do Festival Visões Periféricas e que lá havia sido promovido informalmente a líder do grupo. Nesse momento eu me lembrei da sábia fala de Bernardet na segunda edição da Formação do Olhar. De fato, tudo o que a experiência demonstrava naquele momento é que a institucionalização do movimento estava fragilizando-o, e no debate ficou clara a existência de opiniões contrárias a esse precoce processo de institucionalização. Houve pouco diálogo e o início de uma grande ruptura.

Na mesma edição do Festival, em 2007, foi lançado também um projeto antigo que havíamos concebido junto com a Kinoforum: o site KinoOikos (www.kinooikos.com), janela na internet que exibe mais de 300 vídeos produzidos em oficinas e por coletivos, e os disponibiliza para download e exibição sem fins lucrativos - incentivando e promovendo a ação cineclubista de coletivos e entidades e as trocas criativas entre realizadores. A proposta veio acrescentar essa ação contínua à seção do Festival, que passou a se chamar Mostra KinoOikos Formação do Olhar. Nesse ano, a programação contou com 54 produções, de 37 projetos de todo o país.

Enquanto isso, em São Paulo, a edição de 2007 do VAI contemplou 17 projetos total ou parcialmente voltados a atividades audiovisuais entre os 102 selecionados, com valores de até $\mathrm{R} \$ 18$ mil. Os projetos dos coletivos Fabicine e Cine Becos foram selecionados para continuidade; entre os demais selecionados estavam os projetos do coletivo NCA - Núcleo de Comunicação Alternativa (2007/2008), de Daniel Fagundes (ex-aluno das Oficinas Kinoforum), Fernando Soliares e Diego Soares; Mascate Cineclube, de Thais Scabio e Gilberto Caetano, ex-alunos das Oficinas Kinoforum (2007/2008); CineCampinho (2007/2008); Vídeo Vinil 
(2007/2008), dentre outros.

A partir de uma demanda identificada no Centro Cultural da Juventude, a Prefeitura do Município de São Paulo criou um fundo para co-patrocínio de primeiras obras, destinado aos profissionais iniciantes. O fundo concedeu valor máximo de $\mathrm{R} \$$ 50 mil a cada projeto selecionado. A iniciativa se propôs a ocupar a lacuna existente entre o Programa de Valorização de Iniciativas Culturais - VAI, e as Leis de Incentivo e Fomento. Havia uma zona intermediária descoberta, justamente aquela em que se encontram diversos grupos de jovens produtores de cultura. Este edital abria espaço também para a realização de produtos multimídia - o que é permitido, mas pouco aproveitado no contexto do VAI.

Ainda em 2007, o Ministério da Cultura lançou, através da Secretaria do Audiovisual, o tal concurso (que dera origem à discórdia no FEPA): o $1^{\circ}$. Concurso de Apoio à Produção de Obras Audiovisuais Digitais Inéditas, de curta-metragem, dos gêneros ficção, documentário ou experimental, destinado exclusivamente a pessoas físicas integrantes ou egressas de projetos sociais com foco na linguagem audiovisual, desenvolvidos por entidades sem fins lucrativos. Foi o primeiro edital voltado a alunos e ex-alunos de projetos sociais, uma grande conquista por fim, e destinou $\mathrm{R} \$ 30$ mil a 20 projetos de todos o Brasil (com a proposta de no mínimo 2 por região), para a realização de curtas-metragens de 10 a 15 minutos de duração.

Foram apresentados ao todo 163 projetos. A seleção foi divulgada já em 2008 e, entre os 20 selecionados, são: 11 projetos da região sudeste (dois deles, projetos de alunos das Oficinas Kinoforum), 4 da região nordeste, 2 da região sul, 2 da região sul e 1 da região norte.

Em 2007, a criação do Programa Mais Cultura possibilitou a descentralização e a cooperação entre os entes federativos na realização de diversas ações do MinC, como os Pontos de Cultura, que passaram a ser selecionados, reconhecidos e apoiados em redes municipais e estaduais. Na perspectiva de cooperação, articulação e integração, o Ministério da Cultura estabeleceu parcerias com ministérios, bancos públicos, organismos internacionais e instituições da sociedade civil, e assino acordos 
com governos estaduais e municipais para a implementação das ações do projeto ${ }^{22}$.

Realizaram-se, também neste ano, entre as atividades relacionadas aos Pontos de Cultura: o II Encontro dos Pontos de Cultura do Estado de São Paulo, promovido pelo MinC em Mogi das Cruzes; I Fórum Nacional de Pontos de Cultura e a TEIA2007. O Instituto de Arte e Cultura Garatuja tornou-se Ponto de Cultura no ano de 2007.

Ainda mais mobilizados pelo "primeiro racha" ocorrido no Festival de Curtas em 2007, parte do grupo que fundou o Fórum Cinema de Quebrada juntou-se a entidades, realizadores e coletivos numa nova instância de reflexão e atuação política. Esse coletivo passou a ter reuniões regulares no primeiro semestre de 2008, e optou, no decorrer de seus debates, por retomar o termo Vídeo Popular. Sob a alcunha de Coletivo de Vídeo Popular assumiu, dentre suas prioridades, o desafio que considerava não ter sido superado pelo FEPA: uma certa militância na linha de frente que valorizasse de fato uma atuação forte de base, que valorizasse a troca de experiências e conhecimentos e potencializasse a integração entre os diferentes agentes em ações coletivas.

Na edição de 2008 do Programa VAI, 21 projetos tinham atividade total ou parcialmente voltada à área audiovisual. Foram 705 projetos culturais inscritos, e 115 selecionados. Entre os projetos de audiovisual, estavam: o Panorama do Cinema Brasileiro, do Coletivo NERAMA, para realização de terceira edição desta mostra (Elton Campos e Luciano Oliveira, este último, ex-aluno das Oficinas Kinoforum); Contos de Bairro, de Peu Pereira (ex-aluno das Oficinas Kinoforum); Linha de Montagem, de Rica Saito; Cinema Muda, de Patrícia Alencar (ex-aluna das Oficinas Kinoforum); Click na Lata, do coletivo Mundo em Foco, realizado por Ozana Sousa e Rodrigo Sousa (ex-alunos do Instituto Criar).

A Mostra KinoOikos Formação do Olhar de 2008 teve em sua programação 39 curtas de 37 projetos, vindos de 10 estados brasileiros. O já tradicional Seminário teve

\footnotetext{
${ }^{22}$ Fonte: http://www.cultura.gov.br/site/2009/11/16/minc-e-governo-de-sp-anunciam-300-novos-pontos-de-cultura-no-estado/ http://www.cultura.gov.br/site/2009/02/13/mais-cultura-para-o-brasil-e-o-povo-brasileiro-5/ http://mais.cultura.gov.br/2009/02/09/410/
} 
como foco uma discussão acerca das diferentes formas de profissionalização das atividades dos jovens no audiovisual, buscando estimular a reflexão sobre o surgimento de políticas públicas de incentivo (editais municipais e federais) e a perspectiva de formalização das iniciativas, através de cooperativas, microempresas ou organizações da sociedade civil de interesse público (OSCIPS). Na programação do Seminário, o antigo Fórum de Projetos daria lugar ao Microfone Aberto, momento em que integrantes de coletivos e projetos de oficinas trocam informações, experiências e ideias sobre suas atividades. Neste ano, se discutiu muito as relações com as ideias de função social, mercado, trabalho e transformação.

Em 2008 realizou-se, novamente no Festival Visões Periféricas, um novo encontro do FEPA, convocado através da lista de emails criada após os encontros anteriores do Fórum. A organização do Festival se propôs a custear a ida de duas pessoas por estado para participar deste encontro nacional. Dessa vez, somente de São Paulo, partiu um ônibus (com apoio da Secretaria Municipal de Cultura) repleto de integrantes de coletivos audiovisuais atuantes em São Paulo.

Muitos que estavam presentes ao encontro, de maneira geral já participavam das reuniões regulares como Coletivo de Vídeo Popular e da lista do FEPA discutindo, entre outras coisas, formas de participação colaborativa no Fórum. No entanto, era visível que outros tantos, além do trabalho cotidiano na comunidade, estavam começando a se inteirar dessa articulação com objetivo de mobilização. Neste encontro havia convidados de diversos estados - a convocação via lista de emails do FEPA não teve a resposta esperada, e muitos dos "representantes" foram convidados a participar da discussão uma semana antes do encontro, ouvindo falar pela primeira vez sobre a existência do Fórum na ocasião mesma do convite da organização do Visões Periféricas.

Neste novo encontro, ocorreu mais um embate, desta vez mais polarizado entre Blanco e "os paulistas", acusados de terem ido em grande número para forçar uma posição e, dentre outras coisas, de recusarem as ideias e o que já havia sido combinado no Fórum. Novamente o tema nevrálgico: Blanco insistindo nos benefícios da institucionalização e os então referidos como "paulistas" questionando 
essa ideia e também sua liderança e seu papel de representante perante o MinC. Além dos "paulistas", participantes do Cinema Nosso (ex-Nós do Cinema) se posicionaram fortemente contra essa proposta de institucionalização feita às pressas. Com o debate, a decisão da maioria foi retomar essa discussão no encontro nacional a ser realizado no ano seguinte, entendendo que o FEPA não estaria maduro para esse passo.

Pouco tempo depois, na lista de discussão, o tema da institucionalização foi mais uma vez trazido à tona, novamente colocado como urgente, justificado pela possibilidade de o FEPA indicar instituições para receber um kit de exibição (do Cine Mais Cultura, do MinC). Nova rodada de debates intensos, desta vez, virtualmente. Os participantes de coletivos paulistas se colocavam de novo contra a institucionalização do Fórum, considerando que esta não era a única forma possível de relação com o poder público ou quaisquer outras instâncias e, mais ainda, contra a postura de se passar por cima da decisão tomada no encontro. Por fim, foi perfeitamente possível realizar as indicações de projetos do FEPA através de parceria com o Conselho Nacional de Cineclubes. Mas o desgaste da discussão conflituosa não se apagaria tão facilmente.

Ao final do ano de 2008, já havia 824 Pontos de Cultura ${ }^{23}$ espalhados por todo o Brasil; só no estado de São Paulo, eram 172.

Nesse ano foi realizado o I Fórum Paulista de Pontos de Cultura, com a eleição da Comissão Paulista e indicação de um membro para representar o Estado de São Paulo na Comissão Nacional de Pontos de Cultura. Houve também a TEIA 2008, no Teatro Nacional, em Brasília, além do II Fórum Nacional de Pontos de Cultura e eleição da II Comissão Nacional de Pontos de Cultura. Em pesquisa realizada pelo Pontão de Cultura Mapas da Rede, considerando o período de 2005 a 2008, detectouse que $66 \%$ dos Pontos de Cultura do país desenvolveram atividades na área audiovisual. Neste ano, foram contemplados os projetos de Pontos de Cultura Minha Vila Filmo Eu, do Projeto Olho Vivo (PR) e o Ponto de Cultura Mundo Olhares

\footnotetext{
${ }^{23}$ Fontes: http://www.cultura.gov.br/site/2009/11/16/minc-e-governo-de-sp-anunciam-300-novos-pontos-de-cultura-no-estado/ Fonte: Pontão Mapas da Rede - IPSO Pesquisa 4: Atividades, Linguagens, Público e Temáticas. Acessado em: http://www.pesquisa.utopia.com.br/p004 em 20/02/2009 in O Audiovisual na Rede dos Pontos de Cultura na Grande
} 
Saberes, da Associação Cultural Faísca (DF).

Em janeiro de 2009, após a repetição do conflito acerca da institucionalização, o Cinema Nosso se desligou do FEPA, explicitando seu desacordo com essa tendência:

\begin{abstract}
Discordamos veementemente de qualquer processo de formalização do Fórum como instituição, que, em nosso entendimento, tende a reproduzir padrões mercadológicos ou burocráticos de atuação de grandes companhias. A denominação de cada organização como uma Experiência Popular em Audiovisual (EPA) é um exemplo de como a institucionalização tende a apagar a diversidade e a história de cada uma delas. (Trecho da carta de desligamento Cinema Nosso, Anexo C)
\end{abstract}

Em 2009, após as citadas tentativas de participação no FEPA, o Coletivo de Vídeo Popular foi gradativamente se afastando das discussões do Fórum para se centrar em ações locais, visando uma mobilização mais consistente na cidade. Nesse ano, o Projeto do Vídeo Popular foi aprovado pelo VAI ${ }^{24}$ com uma proposta que previa três ações:

1. O Circuito do Vídeo Popular: com o objetivo de promover uma agenda coletiva de projeções entre os coletivos que realizam trabalhos de exibição e a produção e distribuição de DVDs com programas de Vídeo Popular, com curtas realizados por diversos coletivos de São Paulo e outras localidades;

2. A III Semana do Vídeo Popular: fazer a terceira edição deste encontro uma mostra das produções e encontros para troca de experiências entre os grupos;

3. A Revista do Vídeo Popular: publicação de dois números desse espaço para reflexão, sistematização, registro e divulgação das ações relativas ao audiovisual popular.

Na edição de 2009 do programa VAI houve 644 inscritos, sendo 100 selecionados. Destes, 10 projetos eram de atuação na área do audiovisual. Foram aprovados também o projeto do núcleo S.A.C.I., de Paula e Marcio Moreno (exalunos das Oficinas Kinoforum) e Nossa Tela, de Rogério Souza e Evandro Santos (ex-alunos de oficinas do Cinema Nosso realizadas na capital paulista).

Nesse ano, durante o Festival Visões Periféricas, não houve encontro oficial do FEPA, mas uma espécie de encontro informal. Não havia acontecido um convite

\footnotetext{
${ }^{24}$ Desde 2009 integro a comissão de seleção do VAI, como sociedade civil, representando a Associação Cultural Kinoforum. Por motivos éticos, não avalio projetos em que atuem diretamente alunos ou ex-alunos meus - caso do projeto do Coletivo de Vídeo Popular, que foi aprovado em primeira instância pelos membros que os avaliaram.
} 
aberto ou algo assim, mas coincidentemente, os convidados eram alguns dos mais ativos das conversas virtuais do Fórum e que estiveram no encontro de 2008.

Enquanto ocorria o Festival e esse encontro informal do FEPA, foi divulgada a carta de posicionamento e desligamento do Coletivo de Vídeo Popular do FEPA, contando com duas dezenas de projetos e coletivos paulistas. Os participantes das ações desse coletivo já vinham diminuindo cada vez mais sua participação neste Fórum, entendendo que suas proposições ali sempre eram vistas primeiramente como dos "paulistas" e como "do contra". O coletivo desligou-se, argumentando:

\begin{abstract}
Em sintonia com a nota divulgada pelo Cinema Nosso em janeiro deste ano, não concordamos com a forma atual de representação estabelecida no FEPA, onde propostas são encaminhadas sem que tenham sido amplamente debatidas com seus integrantes. Acreditamos que o vídeo popular é um trabalho que se estabelece na base com uma atuação social marcada por seus próprios atores. Nossa realidade não pode ser homogeneizada e transformada em uma única Organização com um representante institucional. (Carta de desligamento do FEPA, Coletivo de Vídeo Popular, Anexo D)
\end{abstract}

Pouco tempo depois, a Associação Cultural Kinoforum também se desligou do Fórum, argumentando:

Estamos sempre abertos ao diálogo, mas somos contra esse estado de coisas que tornou o FEPA, formal ou informalmente, um agente representativo sem uma real interlocução entre as bases. O FEPA, se colocando como representante de um todo - todo esse ainda em construção -, acaba refletindo um direcionamento insuficientemente identificado com os interesses dos diversos atores sociais envolvidos. (Carta de desligamento do FEPA, Kinoforum, Anexo E)

Semanas após o envio destas cartas, em 13 de agosto, o FEPA manifestou-se oficialmente enviando uma carta para o Coletivo de Vídeo Popular, Kinoforum e Cinema Nosso, convidando-os a permanecerem e abrirem espaço para diálogo:

Considerando todas as reflexões e questões coletivas, que ainda estão em debate e construção, os coletivos, as entidades e os indivíduos presentes no último Festival Visões Periféricas fazem um chamamento àqueles que, por motivos e razões diversas, se desligaram do FEPA, para que voltem a integrar o Fórum, ou que, a princípio, retomemos nossas conversas, a fim de avaliarmos coletivamente os problemas levantados, na perspectiva de contribuir para a construção deste espaço. [...] Avaliamos que vivemos um momento marcado pelo pouco envolvimento dos membros do FEPA em todo o Brasil. Por isso, achamos fundamental convocar também todos os participantes deste Fórum para o desenvolvimento de um processo de 
avaliação geral e retomada de sua organização". (Carta de resposta do FEPA aos que haviam se desligado, 13/08/2009, Anexo F)

A Mostra KinoOikos Formação do Olhar de 2009 marca também uma transição importante: Vanessa Reis, ex-aluna das Oficinas Kinoforum, ex-integrante do MUCCA, e então integrante dos coletivos "Dragão Blasé" e Vídeo Popular, assume a coordenação da seção. Dedicando meus esforços à esta tese, passo a atuar como consultora/supervisora à distância, e na mediação dos debates.

Nesse ano, foram realizados na seção três eventos principais: um debate sobre as definições e fronteiras do campo da educação audiovisual, com a participação de Mauro Reis (coordenador do Ponto de Cultura Alice, Prepara o Gato!), Evandro Santos (do coletivo Nossa Tela, composto por ex-alunos do Cinema Nosso) e Bruno Bralfperr (que não pertence a coletivos, mas realiza vídeos com parceiros desde sua primeira oficina). O "Microfone Aberto", um encontro entre coletivos audiovisuais, realizadores e coordenadores de entidades de diversos estados, presentes no Festival. E uma cerimônia em que o Secretário de Audiovisual Silvio Da-Rin anunciou a segunda edição do edital (Anexo O) de egressos - agora chamado Nós Na Tela e parte do Programa Mais Cultura, do MinC - com uma série de mudanças, que serão detalhadas abaixo.

O Secretário esteve presente em quase o dia todo de eventos e, durante o Microfone Aberto, em meio à discussão sobre a questão das fronteiras da educação audiovisual, questionou e foi informado sobre os motivos da saída do Coletivo de Vídeo Popular e da Kinoforum do FEPA.

Alguns meses após o Festival de Curtas, a SAv (Secretaria de Audiovisual, do MinC) entrou em contato, simultaneamente, com o FEPA, o Coletivo de Vídeo Popular e a Kinoforum, solicitando a indicação, por parte do segmento "experiências populares em audiovisual", de um nome para a nova composição do comitê consultivo da SAv, e se possível, a partir de um consenso. A proposta era que se criasse um espaço para consulta do poder público à sociedade civil, como auxílio no desenvolvimento de políticas públicas para o audiovisual. O comitê foi composto por 14 pessoas de diferente setores da área. 
O FEPA manteve a indicação de Márcio Blanco como titular (como em 2007) e Simone Borges como suplente. O Coletivo de Vídeo Popular enviou uma proposta ousada: quatro representantes (Flavio Galvão, do coletivo Fabicine; Luiz Barata, da Ação Educativa; Rômulo, do CineCrusp; e Vanessa Reis, do Coletivo de Vídeo Popular e Kinoforum), para que em cada reunião, um deles estivesse presente e fosse então responsável pela comunicação com a base.

Aparentemente, o que o coletivo queria evitar era um distanciamento entre aqueles que representam e os que estão, de fato, atuando na "linha de frente". Esse reconhecimento da verdadeira vocação política de uma representação, que perpassa o discurso de muitos membros do Coletivo, e se materializa na própria experiência: o Coletivo é, em grande medida, composto por realizadores e exibidores independentes, e ex-alunos de entidades e projetos da capital paulista. Oportunamente, o Coletivo se beneficia da ausência de um paternalismo de "bom caráter", apaziguador, típico da atuação dos profissionais das OSCIPs nos Fóruns Populares.

A Secretaria do Audiovisual, por fim, fez também uma escolha ousada e definiu como representante titular um dos indicados pelo Coletivo de Vídeo Popular, Vanessa Reis, e como suplente, Simone Borges, do FEPA, e que mora em Brasília.

A escolha do MinC causou incômodo geral. No FEPA, surgiram rumores de que Vanessa Reis, que também trabalha na Kinoforum, teria sido indicada não por sua atuação no Coletivo, mas pelo peso político da ONG. No próprio Coletivo causou indignação o fato de a indicação rotativa não ter sido acatada. E a escolha de Vanessa Reis, dentre os 4 indicados, também levantou suspeitas de que o MinC optou por alguém ligado a uma $\mathrm{ONG}$ de renome.

No final do ano de 2009 houve a segunda edição do edital de egressos, o Nós Na Tela (aquele, debatido na Mostra KinoOikos Formação do Olhar de 2007), com 143 inscrições. O edital continuou apoiando a produção de obras audiovisuais digitais inéditas de curta-metragem, com o valor de até $\mathrm{R} \$ 30$ mil reais cada, com duração de 15 minutos, inspiradas no tema "Cultura e Transformação Social". 
As inscrições, dessa vez, foram voltadas para jovens de 17 a 29 anos, e foram aceitos apenas projetos de documentários e telerreportagens - não poderiam mais ser inscritas obras de ficção. O concurso passou a ser promovido pelo Programa Mais Cultura, por meio das Secretarias do Audiovisual (SAv) e de Articulação Institucional (SAI) do Ministério da Cultura, em parceria com a Associação Brasileira de Canais Comunitários (Abccom) e Sociedade dos Amigos da Cinemateca (SAC). Foi prevista também uma oficina para os contemplados, antes do início da execução do projeto. Após a produção dos programas, os vídeos seriam exibidos nos canais comunitários interessados e nas TVs públicas.

Por ocasião da III Semana do Vídeo Popular, indivíduos e grupos participantes do Coletivo de Vídeo Popular começaram a elaboração de uma carta que manifestava posição contrária a algumas das mudanças do edital. Criou-se uma petição online ${ }^{25}$ que contou com 100 assinaturas, de diferentes lugares do país, e foi enviada à Secretaria do Audiovisual. Observando o tom da carta, se observa a grande capacidade de argumentação do Coletivo de Vídeo Popular, que ainda se revelou extremamente ágil ao enviar a petição antes do final do prazo do edital.

O novo formato deste edital, agora denominado Nós na Tela, tem avanços importantes em relação ao lançado no ano de 2008, especialmente no que se refere à oficina de desenvolvimento de projeto custeada pelo Ministério da Cultura oferecida aos contemplados e à distribuição dos curtas digitais realizados em TV Comunitárias.

Mas entendemos também que o edital sofreu mudanças bastante negativas para as quais não vemos justificativa clara, solicitamos reavaliação de alguns pontos do referido concurso. Assim, solicitamos as seguintes mudanças:

1 - Não restrição quanto ao gênero do projeto: a atual restrição de gênero somada à definição prévia de tema - dá a entender que os participantes ou egressos de projetos sociais devem ou podem realizar apenas documentários ou tele-reportagens, soando como se não tivessem criatividade ou capacidade para realizações ficcionais, autorais ou experimentais. O oposto é facilmente demonstrado através de vídeos já realizados de forma independente ou em oficinas audiovisuais que têm condições mais simples de produção. Além disso, limita as possibilidades de expressão do único concurso voltado a esse público sem motivação clara, e gera uma tendência a uma homogeneização das produções que tende a prejudicar os resultados dos programas.

2 - Não restrição quanto à idade: os participantes e egressos de projetos sociais com foco em audiovisual não são exclusivamente jovens de 17 a 29 anos, principalmente ainda mais levando em conta a novidade do processo de democratização. A participação em projetos de formação audiovisual

\footnotetext{
${ }^{25}$ Disponivel em http://www.petitiononline.com/egressos/petition.html
} 
não tem relação direta com a faixa etária dos participantes, mas com seu acesso à linguagem audiovisual. Não vemos justificativa para que seus participantes não tenham chance de participação neste edital que, a princípio, é de inclusão.

3 - Quanto à distribuição dos vídeos em TV Comunitárias: propõe-se que os vídeos realizados na oportunidade da primeira edição do edital, de 2008, que estarão finalizados em 2010, sejam incluídos no pacote de distribuição em TVs Comunitárias" (PETIÇÃ̃O COLETIVO VÍDEO POPULAR, 2009)

A SAv respondeu a essa carta justificando as limitações à inclusão do edital no Programa Mais Cultura, o que implicou em uma adequação de seus resultados ao perfil do programa, como a restrição de faixa etária, gênero e tema. Além disso, também o fato de que os vídeos serão formatados como um programa de TV para exibição em TVs comunitárias e que, para tanto, seria necessária uma homogeneidade mínima de formatos.

Após a descentralização possibilitada pelo Programa Mais Cultura, a experiência dos Pontos de Cultura cresceu muito e já conta com cerca de 2.500 unidades implantadas em todo país, ao mesmo tempo em que chama a atenção no exterior: os pontos de cultura vêm sendo objeto de teses acadêmicas e de modelo para ações governamentais semelhantes em outros países. A Itália foi o primeiro país, fora do Brasil, a adotar o modelo dos Pontos de Cultura. Em uma iniciativa da Câmara de Deputados e da administração da região do Lazio, onde está situada a cidade de Roma, foi criado o projeto Officine dell'Arte, inspirado no exemplo brasileiro.

Dados apurados em uma recente pesquisa do Instituto de Pesquisa Econômica Aplicada (Ipea) sobre a extensão da ação dos Pontos de Cultura no Brasil indicam a abrangência sobre uma população de cerca de oito milhões de pessoas, numa média de três mil pessoas/ano interagindo por projeto do Programa do MinC. Este público está distribuído entre os que participam diretamente das atividades desenvolvidas nos projetos culturais e entre integrantes da comunidade que assistem às apresentações artísticas ou participam esporadicamente de cursos e oficinas. Também foi assinado acordo de cooperação técnica para implantação de Pontos de Cultura na Áustria.

Nos países ibero-americanos também cresce o interesse pelos Pontos de Cultura. Em uma reunião de ministros da América ibérica e da Comunidade dos 
Países de Língua Portuguesa e do Caribe, realizada em setembro de 2009, no Brasil, representantes de 15 nações assinaram declaração em que consta a decisão de submeterem à próxima reunião de Cúpula dos Chefes de Estado da América ibérica uma proposta de criação do Programa Ibercultura - nos moldes dos Pontos de Cultura -, para ser implantada nos 23 países da região. Também no Parlamento do Mercosul (Parlasul), que reúne representações do Brasil, Argentina, Uruguai e Paraguai, com sede em Montevidéu, a proposta de disseminação do projeto dos Pontos de Cultura por todos os países do bloco econômico foi aprovada na última reunião, realizada no dia 30 de novembro de 2009. A proposta será encaminhada à próxima reunião do Conselho do Mercado Comum, órgão máximo da integração regional, em junho de $2010 .^{26}$

No final de 2009, houve a seleção de projetos de Pontos de Cultura, através da Secretaria de Estado da Cultura de São Paulo, na qual foram selecionados 300 novos pontos. Foram contemplados projetos da ACAHS (Associação Cultural Artística de Heliópolis e Sacomã), do JAMAC Arte Clube, do coletivo Mundo em Foco e da Associação Cultural Kinforoum - projetos a serem executados a partir de 2010, durante três anos.

No momento em que se finaliza a redação desta tese, tanto o FEPA como o Coletivo de Vídeo Popular ainda não definiram como responderão à colocação do MinC. A primeira reunião ocorreu em dezembro, e apenas Vanessa Reis esteve presente - somente uma pessoa por setor audiovisual convocado podia participar da reunião. Estando em Brasília, encontrou-se com Simone Borges, que mora lá, e desde então, se restabeleceu um diálogo - ainda que parcial. ${ }^{27}$

De todo modo, a opção feita pelo Coletivo de Vídeo Popular pela açãoreflexão - as coisas sendo feitas e pensadas a um só tempo, estendendo o presente em oposição a uma busca por "mais do mesmo" em termos políticos - é o que há em destaque no presente, e aponta para um futuro.

\footnotetext{
${ }^{26}$ http://www.cultura.gov.br/site/2010/02/08/pontos-de-cultura-no-exterior/

${ }^{27}$ Um epílogo dessa história, redigido às vésperas da impressão desta tese, encontra-se no apêndice I.
} 


\section{Perfil da EAP}

\subsection{Geografia da EAP - um fenômeno urbano}

O fenômeno da Educação Audiovisual Popular é essencialmente urbano. Ainda que, especialmente através das diferentes Oficinas Itinerantes, diversas localidades do interior do país sejam atendidas, a grande maioria das atividades concentra-se nas capitais, e especialmente, no sudeste.

Experiências estão ou estiveram presentes em 18 estados da federação e no distrito federal; e em todas as regiões do país.

A região sudeste concentra mais que o dobro de entidades do que a soma de todas as outras regiões. Sudeste, $76,5 \%$ contra $33,5 \%$ das demais regiões. Como se vê no gráfico abaixo:

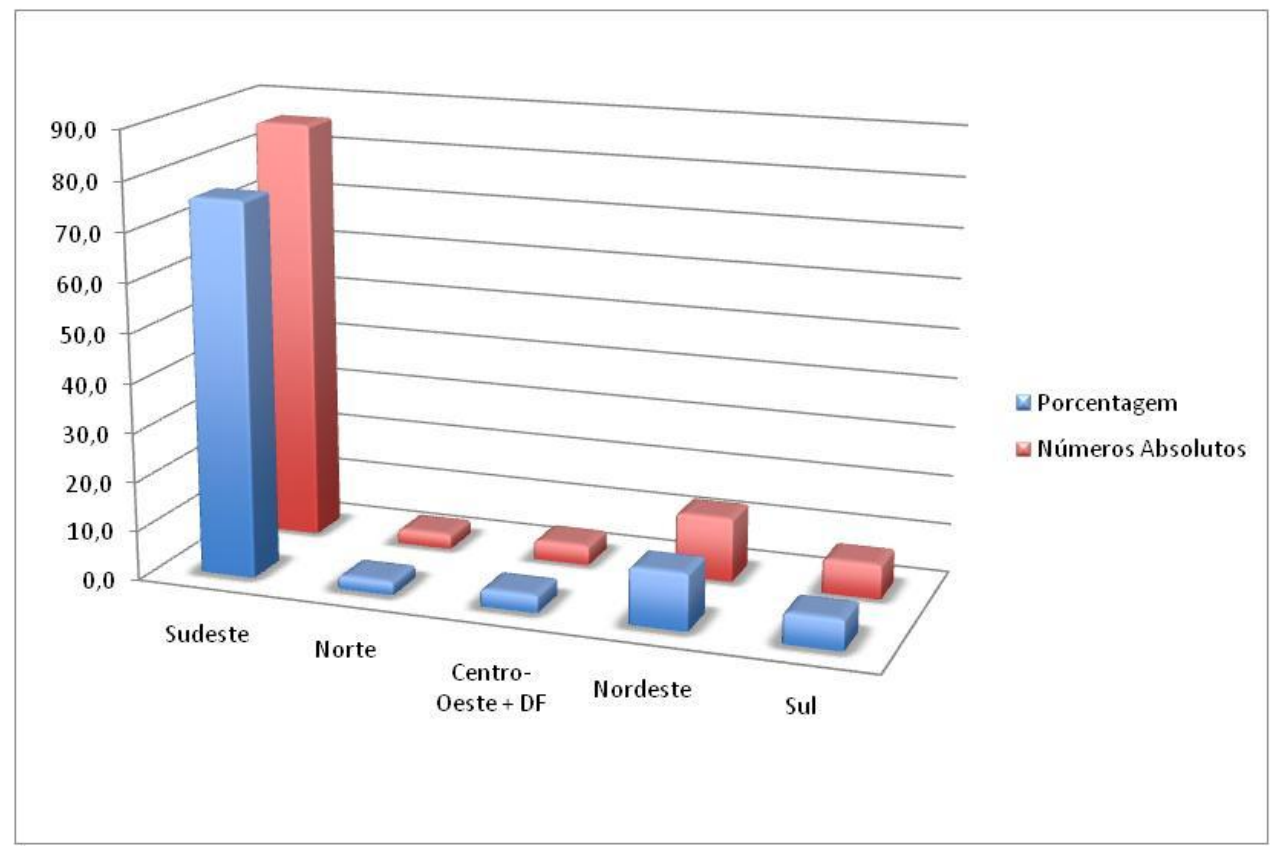

Fonte: Questionário Entidades, 2009. 
Gráfico 2 - Entidades por região do país. Porcentagem e números absolutos.

Há atividades em 40 cidades distintas, com ampla concentração em São Paulo (43 entidades), Rio de Janeiro (32 entidades), Belo Horizonte (8 entidades) e em outras capitais.

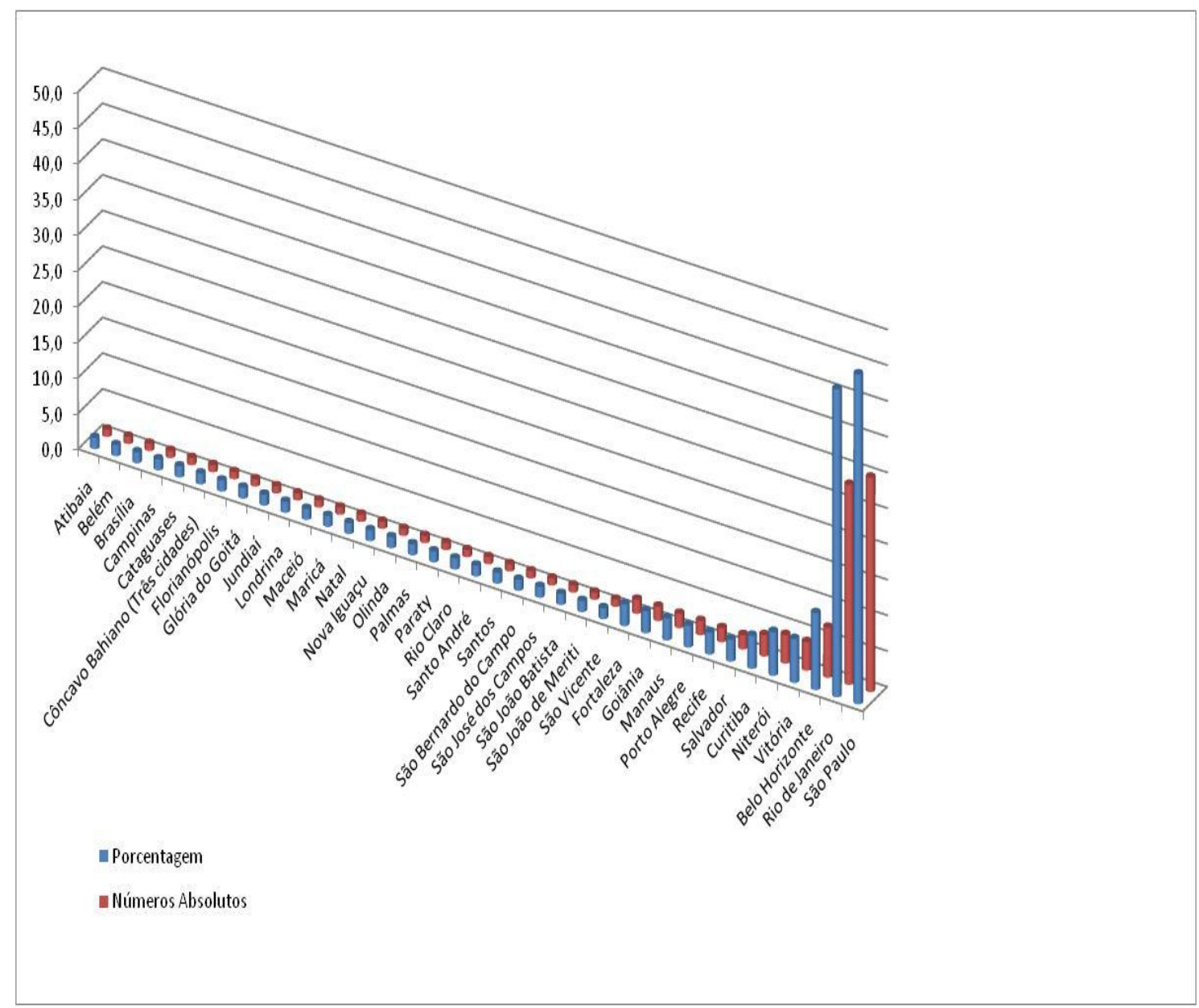

Fonte: Questionário Entidades, 2009.

Gráfico 3 - Entidades por cidade. Porcentagem e números absolutos.

Não cabe no escopo deste trabalho uma análise mais detalhada da localização geográfica das entidades, mas os dados coletados estarão à disposição de outros pesquisadores que possam dedicar-se a tais aspectos.

Para o que interessa à essa tese, trata-se de uma experiência de abrangência significativa, ainda que não se possa afirmar tratar-se de uma experiência 
efetivamente nacional. No entanto os números são impressionantes: a EAP está presente em 40 cidades, localizadas em 18 estados da federação e no Distrito Federal, e em todas as regiões do país.

\subsection{Perfis institucionais e de financiamento}

O perfil institucional de uma entidade define, em geral, as intencionalidades mais amplas de um projeto, assim como direciona as possibilidades de financiamento do mesmo.

O perfil mais frequente na EAP, por ampla margem, são organizações nãogovernamentais qualificadas ou não, a partir do cumprimento de certos requisitos, como Organizações da Sociedade Civil de Interesse Público, ou OSCIPs: 74\% das entidades que participaram do mapeamento possuem esse perfil institucional. Socialmente, as ONGs/OSCIPs representam hoje um importante papel, como públicoalvo de políticas públicas, especialmente federais, para a área de cultura.

A incorporação do ensino audiovisual por políticas públicas promovidas diretamente pelo Estado ainda representa uma fatia pouco significativa da experiência coletiva da EAP. Apenas 9\% das entidades que participaram do mapeamento são de perfil público. Os projetos são promovidos, em geral, por Secretarias Estaduais ou Municipais de Cultura, Educação ou Saúde, em meio a outras "oficinas" e cursos profissionalizantes, e sediados em espaços com equipamento público: Escolas, Casas de Cultura, Bibliotecas, Centros Culturais e Centros de Atendimento Psicossocial (CAPS).

As iniciativas informais, que realizam as atividades sem uma estrutura legal formal, ou grosseiramente "sem CNPJ", chegam a 11\% das entidades pesquisadas. Em geral, possuem pouca mobilidade para participar de políticas públicas ${ }^{28}$ e, muitas vezes, são desenvolvidas sem remuneração. Elas correspondem, de alguma forma, a

\footnotetext{
${ }^{28}$ Apenas em São Paulo, pelo que apuramos, existe um edital que aceita inscrições e também o recebimento do dinheiro por pessoas físicas, o VAI. Em editais da área cinematográfica eventualmente é possível realizar uma inscrição como pessoa física; mas, para receber e gerir o dinheiro, é necessário se associar a uma pessoa jurídica.
} 
uma reminiscência da atitude militante das entidades e grupos que promoviam o vídeo popular.

Empresas e produtoras de cinema vêm desenvolvendo projetos no setor, auxiliadas por leis de renúncia e isenção fiscal, patrocinadores públicos e privados, e representam 5\% das entidades. Suas atividades são, em geral, itinerantes, e realizadas na sede de projetos parceiros.

Mas o que explica essa preponderância de ONGs e OSCIPs sobre os demais modelos? Aguiar destaca o estabelecimento de uma "diferença radical" entre os modelos de atuação das entidades sem fins lucrativos, especialmente durante a ditadura, e no atual período de proliferação de ONGs/OSCIPs, desde a redemocratização.

O combate à ditadura, acelerado a partir da morte de Vladimir Herzog, em 1975, acentuado no Movimento pela Anistia (1977-1979), culminando com a vitória [bastante relativa] da Campanha pelas Diretas Já (1983-1984), aglutina todos os setores contrários aos militares, desde as entidades ligadas à Igreja até as federações de empresários, em torno da mesma bandeira de luta. (AGUIAR, 2005, comentário nosso)

Aguiar, aparentemente supondo que as entidades do vídeo popular seriam totalmente auto-sustentáveis (o que não é consenso), sugere que à tal atuação altruísta e desinteressada das entidades militantes, uma postura assistencialista teria se sucedido, implicando na

rearticulação das entidades sem fins lucrativos em organizações nãogovernamentais, caracterizando-se como Terceiro Setor, após o público e o privado, passando da auto-sustentação ao financiamento externo, isto é, os agentes sociais externos passam da militância ao patrocínio. (AGUIAR, 2005, p. 113)

Essas considerações de Aguiar encontram algum respaldo nos dados coletados em campo: de maneira geral, $85,29 \%$ das entidades declaram possuir algum tipo de financiamento, e apenas $15,71 \%$ declararam não ter financiamento e gerir a entidade com recursos próprios e venda de serviços. No entanto, em muitos casos, o financiamento é feito pelo próprio poder público. O projeto Pontos de Cultura, por exemplo, oferece financiamento de médio prazo apenas para entidades e projetos de interesse público - ou seja, apenas ONGs e OSCIPs, dentre os perfis citados, se 
enquadram - que promovam formação cultural para comunidades de baixa-renda. $\mathrm{O}$ que, de alguma forma, liberta ao menos parte das entidades dos compromissos advindos das parcerias com a iniciativa privada - que tende a exigir mais, e mais diversas contrapartidas, por seus investimentos.

\begin{tabular}{|l|r|r|}
\hline Tipos de financiamento & \multicolumn{2}{c|}{$\begin{array}{c}\text { Número de entidades que } \\
\text { utilizam }\end{array}$} \\
\hline \hline $\begin{array}{l}\text { Autosustentável / mensalidades ou venda de serviços e } \\
\text { produtos }\end{array}$ & 11 & 15,71 \\
\hline Parceria com entidade ou "produtora social" & 1 & 11,43 \\
\hline Doações & 6 & 1,43 \\
\hline $\begin{array}{l}\text { Governo Federal - Ministério da Cultura / sem } \\
\text { especificações }\end{array}$ & 5 & 8,57 \\
\hline Governo Federal - "Pontos de Cultura" & 1 & 7,14 \\
\hline Governo Federal - FUNARTE & 12 & 17,14 \\
\hline Lei Rouanet ou outras leis de incentivo fiscal & 2 & 2,86 \\
\hline $\begin{array}{l}\text { Município de São Paulo - VAI, Programa para a } \\
\text { Valorização de Iniciativas culturais }\end{array}$ & 9 & 12,86 \\
\hline Financiamento Municipal - sem especificação & 1 & 1,43 \\
\hline $\begin{array}{l}\text { Financiamento Municipal - Secretaria Municipal de } \\
\text { Saúde }\end{array}$ & 5 & 7,14 \\
\hline $\begin{array}{l}\text { Financiamento Municipal - Secretaria Municipal de } \\
\text { Cultura }\end{array}$ & 3 & 4,29 \\
\hline $\begin{array}{l}\text { Financiamento Municipal - Secretaria Municipal de } \\
\text { Educação }\end{array}$ & 9 & 12,86 \\
\hline Financimento Estadual & 5 & 7,14 \\
\hline $\begin{array}{l}\text { Financiamento privado - Fundaç̃̃es, institutos ou } \\
\text { organizações }\end{array}$ & 4 & 5,71 \\
\hline Financiamento privado - empresas & 16 & 22,86 \\
\hline Oscilação entre períodos com e sem financiamento & 31,43 \\
\hline $\begin{array}{l}\text { Oscilação de formas de financiamento - público, } \\
\text { privado }\end{array}$ & 22 \\
\hline Editais (genéricos) & 11,43 \\
\hline
\end{tabular}

Fonte: Questionário Entidades. O total excede 100\% pois as entidades tinham liberdade para citar mais de uma fonte de financiamento.

\section{Quadro 1 - Tipos e fontes de financiamento}

É importante destacar também que essa existência de financiamento é relativa; na medida em se detecta, tanto no discurso como no cotidiano, que os patrocínios são irregulares, evidenciam-se muitas "janelas" sem recursos - e mesmo quando há recursos, são em grandeza inferior à necessária. 
Pelo que pude depreender dos discursos, como de minha experiência e visão pessoais, algumas implicações do perfil de financiamento em vigor de fato se destacam na experiência da EAP:

a) vínculo com o setor privado, ou convênios com o poder público (as entidades não são, em geral, auto-sustentáveis);

b) no caso das parcerias com o setor privado - vínculo inevitável da imagem das diferentes entidades com a de seus patrocinadores - , muitas vezes está implicada uma espécie de censura, que eventualmente chega ao ponto de resultar em limitação explícita de alguns temas, e no excesso de atividades, muitas vezes realizadas como forma de oferecer contrapartidas aos apoiadores. Como já observava Alvarenga: "Porque acontece dentro de uma perspectiva capitalista neoliberal, essa democratização propõe também a adoção de procedimentos empresariais, que vão interferir fortemente na dinâmica de produção videográfica das comunidades e - por que não,? - nos produtos" (ALVARENGA, 2004, p. 66). Essa interferência não é detectável nos discursos oficiais da EAP, provavelmente por receio de incomodar aos próprios patrocinadores. No entanto, a partir de minha experiência pessoal e de conversas informais, percebe-se que o que se estabelece não é bem uma censura, senão uma espécie de auto-censura, em que educadores e coordenadores optam por não permitir a realização de produtos sobre temas excessivamente polêmicos - ou que, por exemplo, impliquem em uma crítica direta ou indireta a serviços prestados por patrocinadores à sociedade;

c) informalidade: contratação muito comum de profissionais através de Notas Fiscais de Serviços, e rara oferta de contratação regular via CLT (Consolidação das Leis Trabalhistas) - especialmente pelo receio da descontinuidade dos recursos e eventual impossibilidade de cumprir com compromissos. Trata-se mais de uma decorrência da adoção de procedimentos empresariais neoliberais, em que se busca terceirizar serviços com o objetivo de diminuir custos, especialmente trabalhistas, e inibir a criação de vínculos empregatícios. Como foi noticiado e 
amplamente criticado recentemente em matéria do jornal $O G l o b o^{29}$, tal estado de coisas estimula fortemente o mercado das chamadas "Notas de Favor", em que profissionais compram Notas Fiscais de empresas que prestam os serviços similares aos seus para envio às entidades contratantes. Recentemente, o Ministério da Cultura e a Receita Federal passaram a lidar com maior rigor com relação ao assunto. E diversas entidades passaram a exigir que o nome dos profissionais constasse do contrato social das empresas, pressionando-os a abrir suas próprias empresas apenas para receberem seus salários - com todos os custos que tais operações implicam. Trata-se de um movimento paradoxal e contraditório, em que o rigor adotado pelo poder público não resultou em formalização/regularização dentro das Leis trabalhistas, e sim na criação de um sistema em que as entidades se omitem de quaisquer responsabilidades e os profissionais são obrigados a arcar com todas as despesas e riscos da atuação autônoma e sem vínculo. Por outro lado, tais atitudes das entidades são justificadas pela irregularidade dos financiamentos e pela falta de sustentabilidade dos projetos;

d) sazonalidade/ Insegurança: Falta de vínculo de muitos profissionais para com as entidades, uma vez que, a cada ano, não há garantia de continuidade (exceto em algumas poucas entidades que realizam, com as empresas dos profissionais, contratos semestrais ou anuais), tampouco oferta de benefícios, como férias e $13^{\circ}$ salário.

Estes são os primeiros elementos dados para análise das intencionalidades da EAP: (i) preponderância do modelo ONGs/OSCIPs sobre os demais, a partir de financiamentos públicos e privados principalmente a projetos e não às entidades, que a princípio implica em algum diálogo com os objetivos dos patrocinadores, e em última instância pode gerar alguma auto-censura, a título de evitar incidentes com o financiador; (ii) estabelecimento de procedimentos empresariais, especialmente a terceirização materializada na contratação via Notas Fiscais de serviços; e (iii) sazonalidade e falta de vínculos de seus profissionais. Características que, como apontam Aguiar e Alvarenga, inserem a EAP claramente em um contexto de relações

\footnotetext{
${ }^{29}$ A matéria "Compra de Nota Fiscal esconde sonegação na área da cultura" foi publicada no jornal $O$ Globo em 01/08/2009.
} 
neoliberais, em um pólo oposto ao Vídeo Popular no que tange a financiamento e suas implicações.

\subsection{Nível de dedicação ao tema}

Outra característica que tem implicações na intencionalidade das experiências da EAP é a diversidade nos níveis de dedicação de cada entidade ao tema. O ensino audiovisual ainda não surge, na maioria dos casos, como foco integral das entidades: apenas $15,7 \%$ das entidades são integralmente dedicadas à educação audiovisual. Esse perfil é extremamente relevante e benvindo no âmbito desta tese, uma vez que tais entidades tendem a possuir um ambiente altamente propício para o desenvolvimento de novas metodologias de ensino audiovisual, sendo essencialmente deste grupo as entidades que foram visitadas para a realização de entrevistas presenciais.

Muitas entidades realizam atividades de formação cultural em áreas diversas, nas quais o audiovisual é uma dentre outras linguagens ensinadas. Esse é o perfil de $45,7 \%$ das entidades, que declararam exercer "outras atividades, mas oferecem oficinas audiovisuais contínuas". Entidades com esse perfil em geral beneficiam-se da integração e multiplicidade propiciada pelas diferentes visões e perfis em formação. A continuidade permite também algum apuro e dedicação à criação de meios e didáticas para ensinar, em maior medida que nos perfis a seguir.

No total, 38,6\% das entidades realizam as atividades audiovisuais de maneira muito irregular: $34,3 \%$ das entidades dedicam-se a outras atividades e oferecem oficinas audiovisuais eventuais, e 4,3\% realizaram oficinas apenas em evento único. Em ambos os casos, percebe-se que a descontinuidade é o maior desafio para que se possa detectar o desenvolvimento de estratégias originais de ensino.

O crescimento dos primeiros grupos citados, integral ou sistematicamente dedicados ao ensino audiovisual, criou as condições necessárias para o desenvolvimento de estratégias originais de ensino no âmbito da EAP: emergência do ensino audiovisual, de maneira ampla, como um dentre os principais desafios 
coletivos da entidade e todos os seus agentes, e a subsequente necessidade de criação de estratégias integrando as dimensões técnica e pessoal em função desse aprendizado.

\subsection{Público-alvo}

Outro elemento fundamental em uma investigação das intencionalidades da EAP é seu público-alvo: a quem se dirigem as atividades da EAP?

Se o Vídeo Popular, articulado com os projetos sociais, situava-se de alguma maneira dentro do universo profissional de seu público (os trabalhadores), mais de 20 anos depois, a realidade da militância brasileira é muito diferente:

a) os militantes do "Chão de Fábrica" foram amplamente incorporados pelas instâncias políticas, e o cotidiano dos trabalhadores (agentes e público do Vídeo Popular) intensificou-se a ponto de tornar inviáveis ações culturais de grande porte voltadas a esse público: se não houve um aumento oficial da jornada de trabalho, houve uma forte depreciação dos salários e a disseminação de "pequenos trabalhos temporários" e de jornadas duplas (atuação em dois serviços diferentes) para aumentar o rendimento familiar;

b) os novos movimentos sociais, criados especialmente a partir da década de 1990, já atuam em um novo paradigma, pelo qual integram o chamado "terceiro setor", e dedicam-se a desenvolver projetos sociais que dão conta de públicos-alvo não atendidos e problemas sociais não resolvidos pelo poder público - muitas vezes com o financiamento direto deste;

c) nesse contexto, justamente por se tratar de um público cronicamente negligenciado por políticas públicas - e também como reflexo dos desafios não superados pela educação formal -, os jovens tornaram-se (junto com as crianças) o principal público 
das ações das diversas entidades que foram sendo criadas ao longo das duas décadas;

d) as entidades atendem ainda a outros excluídos, como comunidades indígenas, portadores de necessidades especiais (PNEs), usuários das redes de atendimento psicossocial (CAPS e os CAPS/AD álcool e drogas), descendentes de quilombolas, e professores, especialmente de escolas públicas.

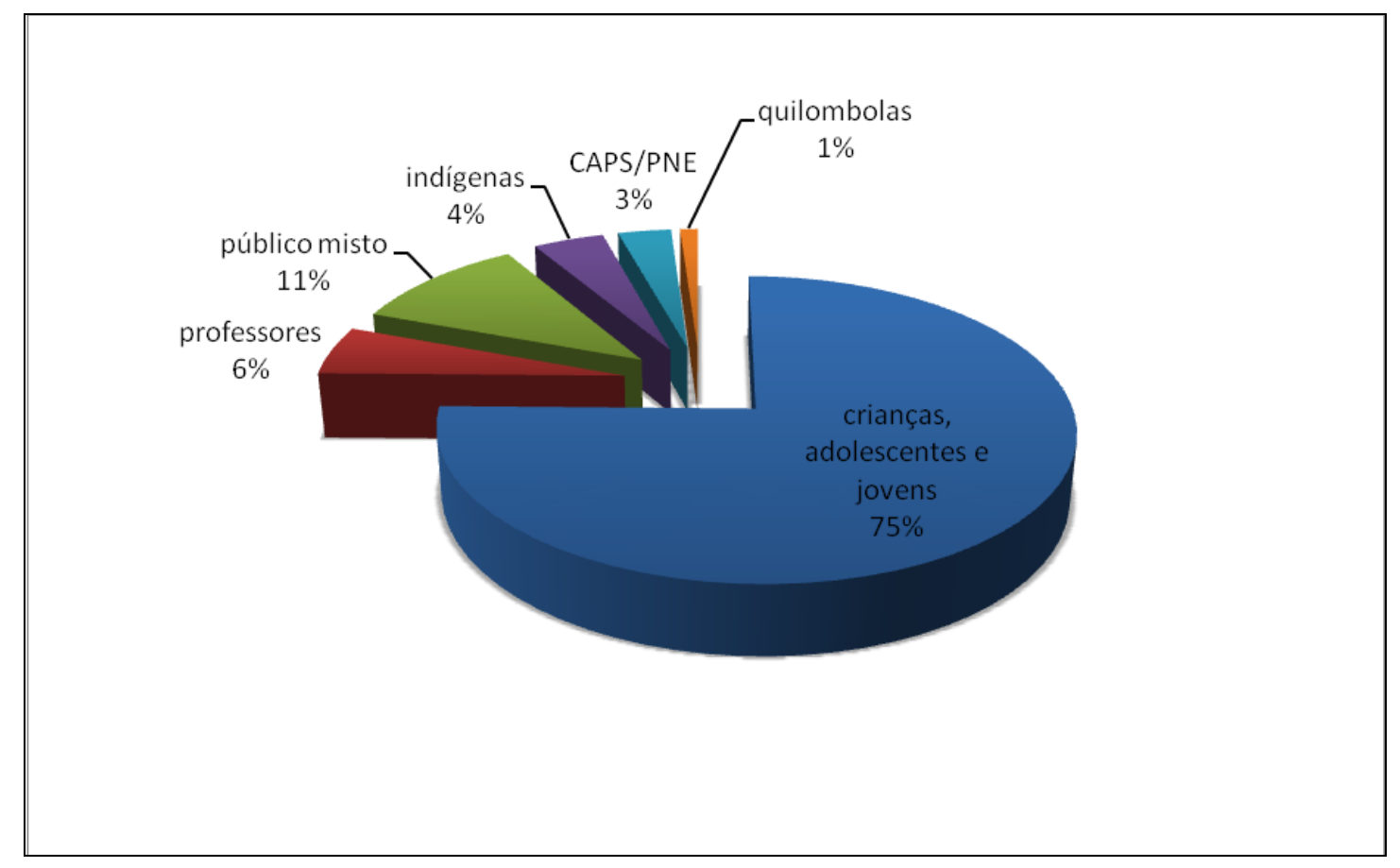

Nota: Elaborado a partir das respostas ao questionário geral das entidades.

CAPS/PNE - Público com necessidades especiais e/ou dependência de álcool/drogas.

Gráfico 4 - Público alvo da EAP

A principal implicação do público-alvo dentre as experiências da EAP é a aproximação com os desafios envolvidos na promoção do desenvolvimento de crianças e jovens, desafios compartilhados com as escolas formais, cuja superação inspira trocas muito bem-vindas: os profissionais da EAP passam a ler e se basear em referências pedagógicas do universo da educação formal, renovando e revitalizando práticas alternativas muitas vezes inviáveis pelo perfil engessado das escolas. Complementarmente, os profissionais da educação formal passam a ter nos 
profissionais da EAP aliados para o desenvolvimento de ações diversas. Como se nota no gráfico, 6\% das entidades da EAP destinam ações a professores. E há ainda o campo inexplorado de formação de professores a partir das conquistas da EAP no âmbito pedagógico.

\subsection{Intencionalidades}

Mas o que dizer das intencionalidades em si? Objetivos são declarados pelas entidades, em um discurso oficial, e materializados, ou não, pelo discurso e ações pedagógicas de coordenadores e educadores; e pela visão que os alunos têm do processo como um todo.

O discurso oficial das entidades, no item de múltipla escolha ${ }^{30}$, aponta com consistência semelhante para três universos:

1. sensibilização audiovisual (indicada por $34,3 \%$ das entidades);

2. formação técnica/ linguagem (indicada por $28,6 \%$ das entidades);

3. inserção laboral (21,4\% das entidades), a partir de duas diferentes vertentes/opções;

- profissionalização (indicada por 12,9\% das entidades),

- empreendedorismo (indicado por 8,6\% das entidades).

A indicação de objetivos gerais, no entanto, pouco revela sobre como as entidades compreendem tais termos, ou em que aprendizados eles de fato implicam o que começa a se desenhar nas respostas à pergunta aberta sobre os objetivos específicos das entidades.

\subsection{Que habilidades o ensino audiovisual pode ajudar a despertar?}

Este subcapítulo apresenta uma análise qualitativa realizada em diferentes

\footnotetext{
${ }^{30}$ No questionário, há um campo de múltipla escolha voltado ao objetivo geral do projeto de ensino audiovisual, em que são apresentadas 4 opções e 1 opção de redação livre.
} 
campos dos questionários para detectar os diferentes tipos de transformação positiva que os textos sugerem e que as entidades e profissionais procuram promover em seus alunos.

Para isso, realizamos uma análise geral dos discursos da EAP, em busca de padrões; a partir destes, criamos um conjunto de categorias, nas quais buscamos abarcar as diferentes habilidades e aprendizados que se sugere, discursivamente, querer promover.

Trata-se de quatro macro-categorias de habilidades e aprendizados ${ }^{31}$, cujos títulos pretendem ser de fácil intelecção: sociais, emocionais, intelectuais e específicos da área audiovisual.

São considerados habilidades e aprendizados sociais: aprender a trabalhar em equipe em uma perspectiva colaborativa; ouvir críticas/criticar; exercitar a tolerância e a autonomia; conviver em harmonia na diversidade; engajar-se nos problemas do mundo; estabelecer contatos e uma rede de relacionamentos; participar da gestão do projeto e exercitar a liderança.

Intelectuais: sistematizar e autogerir a ampliação do próprio repertório; aprender a observar; aprender a pesquisar; aprender a organizar/sintetizar o que foi pesquisado; aprender a criticar discursos, objetos e atitudes, usando conceitos; analisar, usando conceitos; expressar-se, a partir das próprias percepções e análises; ampliar o escopo do olhar; descobrir e investir nas próprias potencialidades.

Emocionais: ampliação do autoconhecimento, auto-estima, desenvoltura e confiança - em si e nos outros; desenvolvimento da capacidade de focar-se; motivação por transformar-se positivamente; ampliação da capacidade de estabelecer vínculos, com pessoas ou coisas, de exercitar a paciência/cautela e de ter persistência; descobrir e investir nas próprias potencialidades.

Específicos: aprendizados e práticas dos âmbitos: técnico (aspectos

\footnotetext{
${ }^{31}$ Estas categorias nos serão úteis em diversos momentos deste subcapítulo e, especialmente, no Capítulo 4.
} 
diretamente ligados às práticas audiovisuais); linguagem (aspectos voltados à concepção e desenvolvimento dos diferentes elementos conceituais e práticos que orientam a realização); e história (aspectos voltados à ampliação e diversificação do repertório dos alunos).

Em busca de uma resposta à questão implicada neste subcapítulo, submetemos agora o campo "Objetivos específicos dos projetos de ensino audiovisual" do questionário voltado às entidades nessas quatro categorias. Obtivemos a resposta que se vê na figura abaixo:

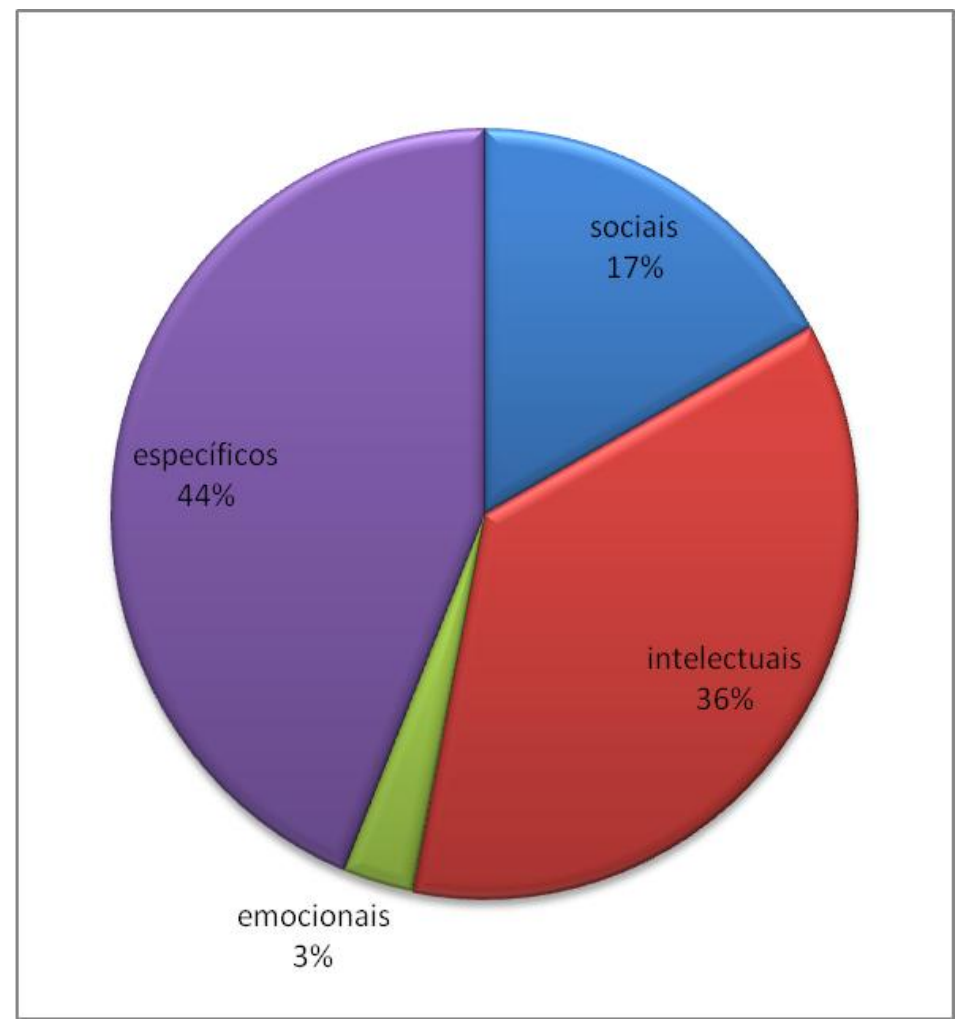

Fonte: Questionário com Entidades.

Gráfico 5 - Habilidades sugeridas no campo objetivos específicos do projeto audiovisual

A partir de tais categorias, se nota, no discurso das entidades:

a) grande ênfase em aspectos específicos do audiovisual (as categorias desse grupo chegam a $44 \%$ das menções, especialmente os aspectos técnicos e de linguagem); 
b) preocupação com habilidades intelectuais (36\% das menções totais), especialmente com o desenvolvimento do repertório, e das capacidades críticas e de análise;

c) preocupação com os aspectos sociais (17\% das menções), especialmente no que diz respeito a um possível engajamento político-social de seus ex-alunos;

d) baixo número de referências a habilidades emocionais, como autoconhecimento e auto-estima (3\%).

Em seguida, submetemos o discurso de educadores e coordenadores, no item do questionário específico que remete aos aprendizados que o projeto pode promover às mesmas categorias.

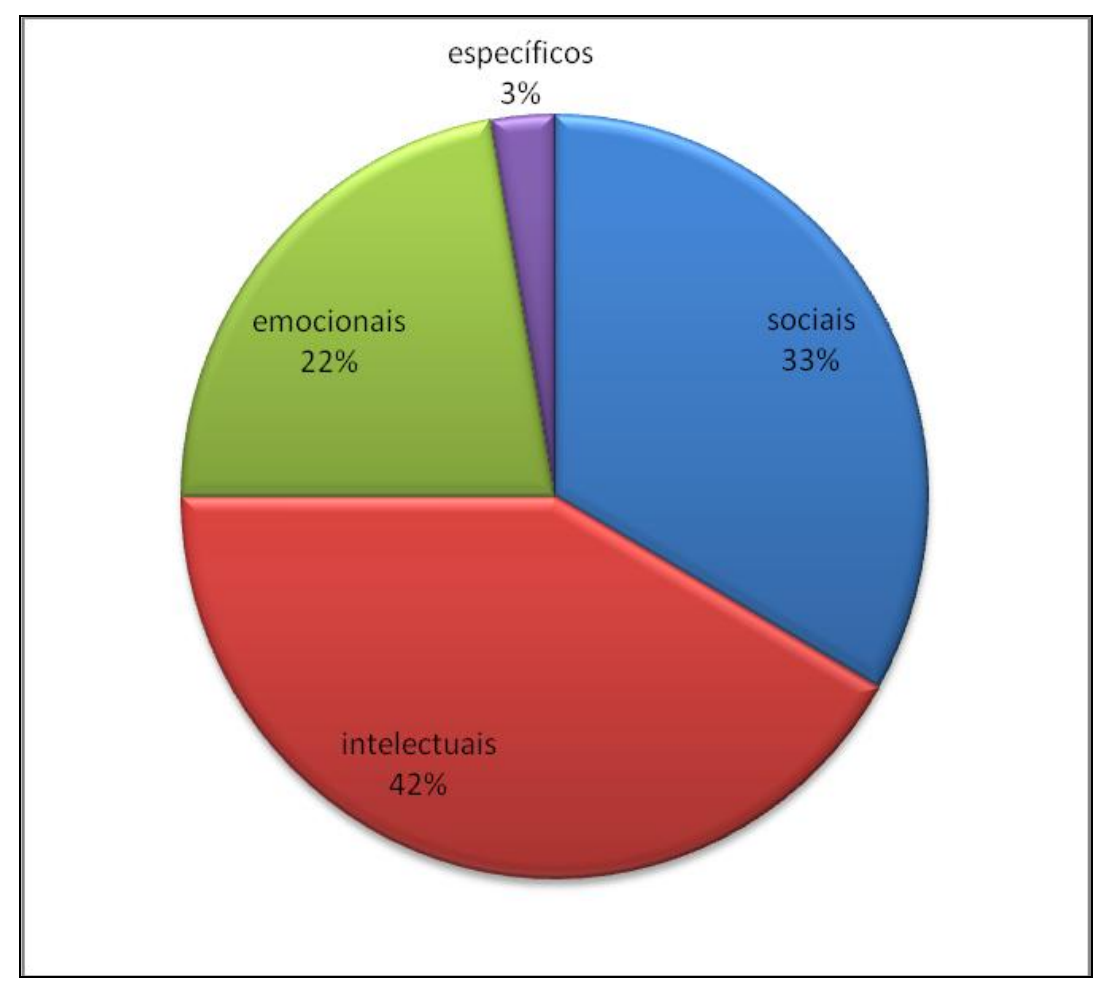

Fonte: Questionário com Coordenadores.

Gráfico 6 - Habilidades sugeridas por coordenadores no campo de tema afim

No discurso dos coordenadores, nota-se:

a) baixíssimo número de menções às habilidades específicas do 
audiovisual (3\%), especialmente em comparação com o discurso das entidades ( $45 \%)$ e educadores $(11 \%)$;

b) isso em oposição a uma grande preocupação simultânea com os demais campos de habilidades: sociais (33\%), intelectuais (42\%), emocionais (22\%) e holísticos (15\%). O que esses dados sugerem é que o cotidiano dos coordenadores é repleto de desafios que os "empurram" no sentido de criar condições para o desenvolvimento de outras habilidades que não as técnicas - o que não é um dado óbvio, e que constitui outro elemento bastante singular da EAP.

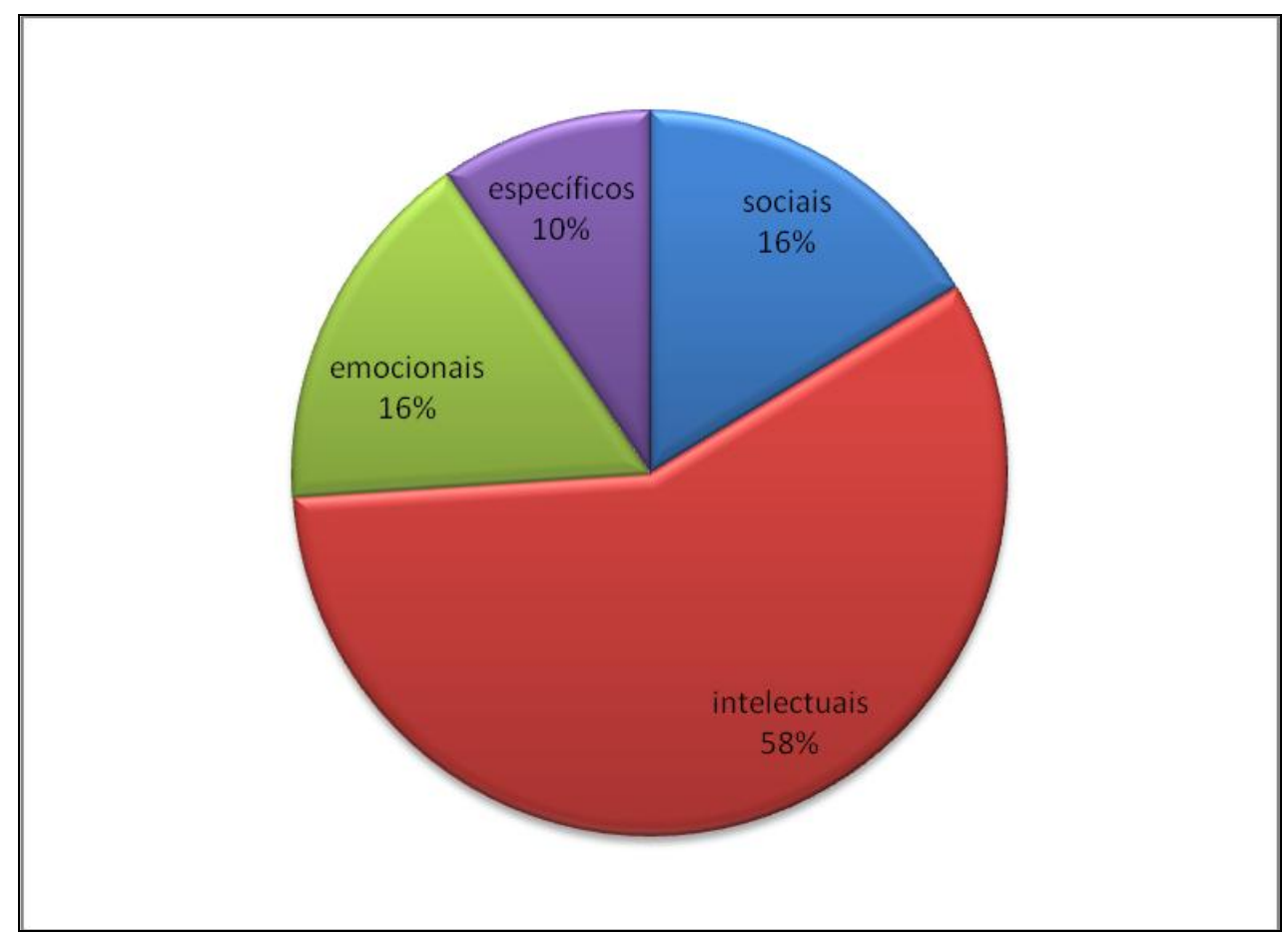

Fonte: Questionário com Educadores.

Gráfico 7 - Habilidades sugeridas por educadores no campo de tema afim

Destaca-se, no discurso dos educadores:

a) número baixo de menções às habilidades específicas do audiovisual (10\%), em comparação com as entidades (44\%), mas relativamente mais alto em comparação aos coordenadores (3\%) (o que sugere que, apesar de sujeitos aos mesmos desafios - de ter que dar conta de muitos outros objetivos além do âmbito específico do audiovisual -, os educadores preocupam-se mais com os temas 
deste âmbito);

b) grande ênfase dada às habilidades intelectuais (58\%), especialmente observação, crítica, análise e expressão (em sintonia com as entidades: $36 \%$ );

c) preocupação semelhante à das entidades com relação às habilidades sociais ( $16 \%$ das menções contra $17 \%$ das entidades) especialmente no que diz respeito a um possível engajamento político-social de seus ex-alunos e também às suas habilidades para trabalhar em grupo. (Isso demonstra também a percepção dos educadores com relação à necessidade de se despertar atitudes e habilidades que potencializem sua inserção e atuação social.);

d) significativo número de referências à habilidades emocionais (16\%), como autoconhecimento e auto-estima - especialmente em comparação com os coordenadores $(21 \%)$. 


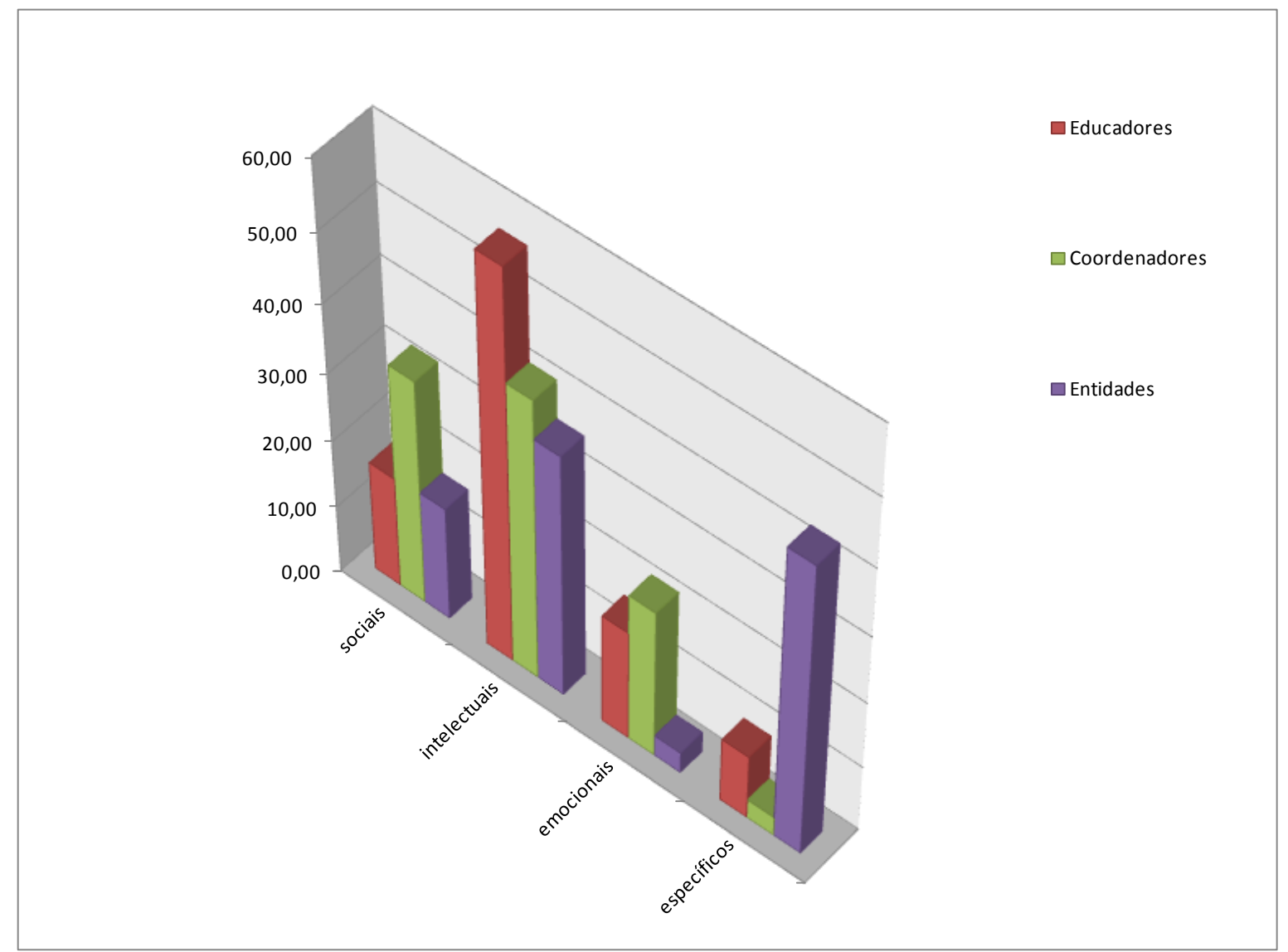

Fonte: Questionários com Entidades, Coordenadores e Educadores. 2009.

Gráfico 8 - Habilidades identificadas nos objetivos das entidades versus habilidades que os educadores e coordenadores buscam despertar

Uma análise mais geral desse conjunto de dados, bem como do gráfico acima, sugere algumas respostas à nossa pergunta inicial "que problemas essa experiência se propõe a resolver?":

a) há uma preocupação coerente, geral, e significativa (entre 16 e $33 \%$ ) com o desenvolvimento de habilidades sociais, tais como aprender a trabalhar em equipe; ouvir críticas, criticar; ter tolerância; conviver; engajar-se; estabelecer contatos; exercitar a liderança;

b) há uma preocupação ainda mais significativa (entre 36 e 58\%) e geral com o desenvolvimento de habilidades intelectuais, tais como: ampliar o repertório; aprender a observar; pesquisar; 
organizar, sintetizar; criticar; analisar; expressar-se;

c) há uma preocupação desigual com o desenvolvimento de habilidades emocionais (entre $3 \%$ e $22 \%$ ), demonstrando a existência de um "campo de problemas" definido e comum, mas que talvez ainda esteja sendo um pouco negligenciado, tanto na ponta (pelos educadores) como na base (na gestão da entidade), possivelmente, deixando os coordenadores isolados com preocupação e busca de soluções para o assunto;

d) há uma preocupação ainda mais desigual com as habilidades específicas da área audiovisual (de 3\% a 45\%), o que revela apesar de o discurso oficial das entidades apontar para uma formação nesse sentido (45\%) - que educadores (11\%) e coordenadores (3\%) tendem a priorizar amplamente $\mathrm{o}$ desenvolvimento de outras habilidades no processo.

Para dar conta dessas intencionalidades, entidades, coordenadores e educadores mobilizam uma série de autores e teorias de referência, que os auxiliam, em diferentes medidas, a estabelecer suas metodologias e práticas pedagógicas cotidianas.

\subsection{Propostas metodológicas}

Havia, no questionário geral, e também nos específicos (para coordenadores e educadores) um campo que sugeria a descrição da proposta metodológica da entidade e a citação, caso houvesse, de seus autores de referência.

Pressupomos aqui que a proposta pedagógica de um projeto pode ser definida a priori, em planejamento, e/ou durante o próprio processo, e/ou a posteriori.

A priori seria possível construir uma proposta:

a) seguindo uma metodologia pré-existente de maneira mais direta;

b) integrando diversas referências em uma proposta original, pré-concebida 
como tal.

De todo modo, nos parece claro que, uma vez que há uma prática educativa em andamento, conscientemente ou não, também há uma proposta metodológica. E, nesse sentido, $67,1 \%$ das iniciativas afirmam possuir proposta metodológica definida.

Eventualmente, uma proposta pode ser realizada de maneira tão intuitiva integrando conhecimentos variados da experiência de cada profissional -, que eventualmente só venha ser detectada justamente a posteriori, a partir dos traços pedagógicos que apresentou. Nesses casos, muitas vezes os agentes que constroem essa metodologia no cotidiano não valorizam sua própria construção, ou não se dão conta de que, mesmo em processo, trata-se também de uma proposta: 32,9\% das entidades afirmam não possuir proposta metodológica definida.

Dentre as entidades que afirmam não possuir proposta metodológica, encontram-se projetos de renomada atuação, como Geração Futura (do Canal Futura) e a pioneira Associação Novolhar, o que sugere que algumas entidades tenham compreendido a pergunta no sentido de se existiria uma proposta pedagógica materializada em um método sistematizado, sem considerar um método em processo como também uma proposta.

A análise da descrição de metodologias inseridas neste campo orientou o desenvolvimento do Capítulo 3, juntamente com a análise dos autores mencionados que veremos no próximo subcapítulo.

\subsection{Autores de referência}

No campo livre voltado à descrição da proposta metodológica era sugerido que as entidades descrevessem também, caso houvesse, os autores utilizados como referência.

A partir da análise desse campo, temos que, de maneira geral, as entidades 
desenvolvem suas atividades de maneira original e independente de autores ou métodos pedagógicos relacionados diretamente a autores: $62,86 \%$ das entidades não mencionam nenhum autor na descrição de sua proposta, e $37,14 \%$ do total mencionam ao menos um autor como referência.

A forma como a contribuição desses autores é integrada às metodologias e ao cotidiano das entidades é muito irregular e variada, mas o diálogo com eles enriquece e dá perspectiva às ações realizadas.

\section{Menção direta e espontânea a autores, entre questionários e entrevistas}

No total, 26 entidades realizaram alguma menção a autores: Paulo Freire foi citado espontânea e nominalmente 21 vezes (ou seja, 80,77\% das menções); Lev Vygotski foi mencionado 5 vezes (19,23\%); Edgar Morin foi mencionado 4 vezes (15,38\%); Mario Kaplún, Jesús Martín-Barbero, Celestin Freinet foram mencionados 3 vezes $^{32}(11,54 \%)$; os demais 27 autores $^{33}$ foram citados apenas uma ou duas vezes.

Alguns, entre os autores mais citados e os apenas citados, são considerados precursores de diferentes campos, que dialogam entre si:

a) a educomunicação indica Celestin Freinet, Paulo Freire e Mario Kaplún dentre os autores que fundamentam seus princípios;

b) Alexander Neill, Celestin Freinet, Freire e Rubem Alves são considerados também precursores tanto de um campo conhecido como educação democrática, que se materializa hoje em mais de 200 escolas em todo o mundo, como da chamada educação libertária, movimento que culminou com a realização de experiências escolares anarquistas;

c) Paulo Freire é mundialmente conhecido por seu método de educação

\footnotetext{
${ }^{32}$ Fui mencionada nominalmente três vezes por profissionais que atuam ou atuaram diretamente comigo.

${ }^{33}$ Autores mencionados uma ou duas vezes nos questionários de perfil das entidades: Abdalaziz de Moura Xavier de Moraes, Alfredo Veiga-Neto, André Brasil, Anton Szandor LaVey, Arlindo Machado, Bernard Lahire, Bernardo Brant, Charles Sanders Peirce, Darcy Ribeiro, Doc Comparato, Eduardo Coutinho, Etienne Delacroix, Fernando Rabelo, Glauber de Andrade Rocha, Ismail Xavier, Ismar de Oliveira Soares, Jean Baudrillard, Jean William Fritz Piaget, Juarez Dayrell, Madalena Nogueira dos Santos, Paul-Michel Foucault, Pierre Félix Bourdieu, Pierre-Félix Guattari, Rubem Alves, Alexander Sutherland Neill, Vilém Flusser, Walter Benedix Schönflies Benjamin.
} 
de adultos e sua Pedagogia do Oprimido. Suas teorias, incluindo a radical revisão proposta na Pedagogia da Autonomia, abordam temas de total sinergia com a educação democrática - sendo Freire, como citado, muitas vezes considerado também um autor desse campo.

O amplo universo de referências mencionado pela equipe das entidades demonstra a abrangência da constante pesquisa empreendida por estes em busca de experiências e teorias que deem conta de auxiliá-los na construção cotidiana de propostas e na superação de desafios.

É através de um diálogo criativo direto com esses autores e teorias que a Educação Audiovisual Popular vem se desenvolvendo nos últimos vinte anos - e de alguma maneira, vem dando conta dos mesmos problemas abordados por estes, e por isso, de outros mais particulares. Mas, quais dentre os autores citados podem oferecer chaves para a compreensão das conquistas obtidas pela EAP em diferentes âmbitos de aprendizado? 


\section{Conceitos e práticas de gestão}

\subsection{PedagoDia}

O cotidiano de uma entidade é, em geral, bastante atribulado. A gestão das atividades educativas, em si, toma praticamente todo o tempo disponível. E os educadores, coordenadores e gestores, geralmente acumulam atividades administrativas, e ainda têm que preencher relatórios, visitar e receber visitas de patrocinadores e imprensa, dentre outras demandas.

Antes de refletirmos sobre os autores e métodos sugeridos pelos discursos da EAP, uma pequena provocação: como se constrói uma proposta pedagógica complexa, que promova simultaneamente a formação técnica e aprendizados não técnicos, em um cotidiano tão intenso? Como a contribuição de um autor ou método integra-se a esse cotidiano?

Uma autora, que coordena uma entidade de São Paulo, que não é especialmente dedicada ao vídeo mas possui atividades eventuais, vem desenvolvendo um "livrepensar" sobre esse aspecto específico da atuação dos movimentos sociais que utilizam o fazer cultural como ferramenta: a constante relação entre o fazer e o pensar. Ela cita, dentre seus autores de referência, figuras que surgem com frequência no nosso levantamento.

A Casa do Zezinho é uma entidade atuante no Parque Santo Antônio, zona sul de São Paulo. Fundada em 1994, atende cerca de 1200 crianças e jovens de baixa-renda, em sua maioria moradores de favelas localizadas no chamado "Triângulo da Morte", composto também pelos bairros Jardim Ângela e Capão Redondo. 
A experiência pedagógica da Casa foi apresentada no livro A Pedagogia do Cuidado, escrito por sua fundadora, Dagmar Garroux, em parceria com o educador Celso Antunes.

Os "zezinhos", como são chamados, frequentam a casa, ou antes, ou depois da escola - quem estuda de manhã, frequenta a casa à tarde, e vice-versa -, organizados em grupos que respeitam critérios como idade, série e desenvolvimento emocional. Frequentam cursos variados de arte, esportes e iniciação profissionalizante.

O livro é dividido em duas partes: a apresentação mais informativa e teórica da experiência; e uma compilação de histórias a partir das quais é possível perceber as características de sua abordagem pedagógica.

$\mathrm{Na}$ primeira parte, Antunes relacionou a proposta pedagógica da casa, por diferentes vias: a Celestin Freinet, "pois as crianças são protagonistas do que fazem e aprendem"; a John Dewey, "descobrindo-as na curiosidade, a cada momento excitada, desvia-se de Freinet e chega-se a pensar em Dewey"; a Paulo Freire, "que melhor que ninguém, entendeu o oprimido e, conhecendo seu horizonte verbal, descobriu caminhos de um ensino que ironizava convenções"; e a Maria Montessori, "que saiu da explanação para ensinar que tocar, lamber, cheirar e falar é coisa que na escola se aprende”. (ANTUNES; GARROUX, 2008a, pp. 36,37)

Aqui é Antunes quem vê a influência de autores na casa. Mas como a casa se vê? Antunes questionou Dagmar, ou como é conhecida por todos, Tia Dag, sobre qual ou quais as referências pedagógicas mais importantes para o trabalho da Casa do Zezinho. Tia Dag Respondeu:

É a Pedagodia, feliz fusão da palavra pedagogia com os desafios do dia-a-dia. Estudamos Freinet e Piaget; discutimos Paulo Freire, Montessori, Vygotsky, Dewey e outros muitos, mas, como atuamos cercados pela necessidade de soluções prementes, não podemos nos sentir engessados por planejamentos rígidos, comandados por linhas procedimentais previsíveis. Quem fala de nosso próprio passo é o desafio do caminhar, a intriga do cotidiano. O melhor a fazer não é o que os rígidos programas prometem, os estáveis projetos estipulam, mas a resposta pronta ao problema de cada dia que em cada criança a toda hora se manifesta. Não é apenas a Pedagogia; é muito mais que isso: trabalhamos a emergência; construímos com seriedade, moldados pelo grito da hora, pela nossa pedagoDia. (Op. Cit., p. 
O conceito de pedagodia é amplamente ilustrado pelas diversas histórias relatadas por tia Dag e sua equipe. Nas emergências e dificuldades do cotidiano, a equipe da Casa do Zezinho não opta por soluções autoritárias; estabelece vínculos, acordos poéticos e práticos muitas vezes bastante heterodoxos - sem, contudo, que as leituras e referências, estudadas por toda a vida, sejam acionadas conscientemente.

Como comentam os autores, educadores muitas vezes não sabem que, ao criticar determinados mecanismos de ensino, estão se inspirando e dialogando com determinados fundamentos epistemológicos, ainda que poucos sejam assumidamente freireanos ou piagetianos: "Em verdade, as aulas estão estruturadas por esse pensar pedagógico nem sempre assumido por ser aprendido, quem sabe, de um professor que o marcou, de um colega com quem aprendeu, ou de livro que leu, filme que assistiu". (Ibidem, p. 38)

Essa situação é ilustrada, na EAP, pelo discurso do coordenador do projeto Alice, prepara o gato!, Mauro Reis:

Difícil falar de referências bibliográficas, aqui. As aulas foram pensadas por três patetas que partiram da seguinte ideia: como cada um de nós três gostaríamos de ter tido o nosso primeiro curso/oficina de cinema na vida? Daí, tome mistura mnemônica de professores que nos marcaram, passagens de livros que não mais nos lembrávamos, de autores, etc. (Questionário com Alice, prepara o gato!, 2009)

Como na PedagoDia de Garroux, nas práticas de Educação Audiovisual Popular, o diálogo com a pedagogia se dá de maneira irregular, ora conscientemente ora inconscientemente; e é uma construção de educadores que, de um jeito ou outro, intuem e aplicam suas práticas educacionais, se ajustando aos desafios do cotidiano. Como observam Garroux e Antunes: "Todo grande educador, seja quais foram as fontes de sua inspiração filosófica, vive mais uma pedagodia que o sentido livresco de uma pedagogia clássica.” (Op. Cit., p. 38)

$\mathrm{Ou}$, como propomos a partir desse momento, vive-se, no nosso universo de interesse, uma pedagodia audiovisual. 


\subsection{Freire onipresente}

Os dados indicam a referência a Paulo Freire nos questionários e nos discursos de coordenadores e educadores com muita frequência - e eventualmente até como autor isolado. No discurso, ele é praticamente onipresente - mais de $80 \%$ das entidades que mencionam algum autor, o mencionam -, e está inserido em diálogo com autores associados a campos diversos. Ou seja, Freire "paira onipresente" sobre a soma de todas as outras referências citadas e, de alguma forma, se consideramos a experiência da EAP, podemos, sem medo de que o neologismo passe despercebido, chamá-la de "freireana".

Mas, quando uma entidade menciona Freire como referência, a que Freire está se referindo? O intelectual e educador brasileiro teve uma brilhante e longa carreira, na qual publicou dezenas de livros, atuou como secretário da Educação, promoveu suas ideias em diversos continentes, e concebeu um método revolucionário de educação de adultos, que o inseriu na geografia mundial da área da educação. Ao longo de sua carreira, foi amadurecendo suas reflexões, comentando e aprofundando questões apontadas nos livros anteriores, e é possível citar Freire para dar conta de um abrangente universo temático dentro do campo da educação.

Por outro lado, se a pedagogia audiovisual é construída na urgência do dia-adia, qualquer que seja a influência de Freire, ele estaria sendo constantemente reinventado de maneira "antropofágica". Como ele mesmo sugere em uma passagem de Pedagogia do Oprimido: "Só existe saber na invenção, na reinvenção, na busca inquieta, impaciente, permanente, que os homens fazem com o mundo e com os outros. Busca esperançosa também.” (FREIRE, 2005, p. 67)

Observando de que forma ele é inserido nos discursos da EAP, talvez encontremos uma pista sobre como se dá essa reinvenção.

O educador Leonardo de Miranda Santos, da CUFA, menciona que textos de Freire fizeram parte de sua formação; e pouco depois descreve sua própria prática como "além da disseminação de conhecimento, onde através de dinâmicas de grupo, 
procurei fazer com que acontecesse uma interação entre os alunos, beneficiando o convívio e auxiliando que o conteúdo programático fosse dado sem problemas." (Questionário com Leonardo Miranda Santos, 2009)

Destaco, no texto de Santos, a expressão "além da disseminação de conhecimento", que remete a um conceito bastante caro à Freire: a crítica à educação bancária, na qual, segundo ele, transfere-se conhecimento, ao invés de criar as condições necessárias à sua construção:

a grande tarefa do sujeito que pensa certo não é transferir, depositar, oferecer, doar ao outro, tomado como paciente de seu pensar. [...] A tarefa coerente do educador que pensa certo é, exercendo como ser humano a irrecusável prática de inteligir, desafiar o educando com quem se comunica e a quem se comunica, produzir sua compreensão do que já vem sendo comunicado." (FREIRE, 1989, p.38)

Segundo Freire, o educador deveria trabalhar junto com os educandos, em uma aproximação rigorosa e científica dos “objetos cognoscíveis", através da qual seria possível aprender criticamente: "Nas condições de verdadeira aprendizagem, os educandos vão se transformando em reais sujeitos da construção e reconstrução do saber ensinado, ao lado do educador, igualmente sujeito do processo.” (Op.Cit. p.26)

O Cinema Nosso, mesmo sem mencionar Freire, faz uso de termos que também remetem a esses conceitos de Freire:

Os educadores não são mestres, donos de um saber que deve ser transferido aos alunos (educação bancária), mas atuam como mediadores de um processo em que se valoriza o conhecimento e a história de cada participante. A educação torna-se, assim, um processo estimulante, em que os educandos têm prazer em participar. Neste sentido, nossa ação educativa é coletiva e solidária, sem a imposição do "saber-de-quem-sabe" no suposto “vazio-de-quem-não-sabe”.. [...] (Questionário com Cinema Nosso, 2009)

O texto do Cinema Nosso aponta, em seguida, para uma outra característica fundamental do pensamento de Freire: a visão libertária que ele propõe no que tange à atuação do educador. "É um processo que privilegia um diálogo entre o educador e o educando, onde há sempre parte de um no outro." (Questionário Cinema Nosso, 2009). E no dizer de Freire: “É preciso (...) que, desde os começos do processo, vá ficando cada vez mais claro que, embora diferentes entre si, quem forma se forma e reforma ao formar, e quem é formado forma-se e forma ao ser formado.” (Op. Cit. p. 23) 
Outra característica do pensamento de Freire é a ideia de educação como prática da liberdade, que, "ao contrario daquela que é prática da dominação, implica a negação do homem absoluto, isolado, solto, desligado do mundo, assim como a negação do mundo como uma realidade ausente dos homens. (Ibidem, p. 81)

No discurso de Azevedo, também educador da CUFA, podemos encontrar um dos poucos vestígios de uma abordagem mais alinhada às experiências militantes, que se inspiravam nessa fase de Freire. Azevedo cita o autor e o associa a ideia de que "o audiovisual é a ferramenta de combate político contemporâneo". (AZEVEDO, 2009)

Valdo Siqueira, coordenador da Aldeia, admite utilizar escritos a que chama "paulofreireanos" para dar conta de temáticas do universo do desenvolvimento da autonomia que ele detecta originalmente no filósofo Walter Benjamim: "Como estudo a Estética filosófica, oriento minhas reflexões pelos estudos do pensador alemão Walter Benjamin. Não necessariamente são passados textos de Benjamin aos educandos, porém, escritos paulofreireanos, onde a questão da autonomia preconizada nas entrelinhas do alemão estão sempre presentes no plano pedagógico". (SIQUEIRA, 2009)

Quatro jovens educadores das Oficinas Tela Brasil admitem se inspirar em Freire, de maneiras diversas: Jefferson Santos afirma que o autor "teria como base um conceito pedagógico democrático"; Rodrigo Santos Souza, que, além de educador, coordena os projetos Clik na Lata e Mundo em Foco, menciona, simplesmente, "Paulo Freire". Jefferson Barbosa assume que o autor é seu ponto de partida: "A partir de Paulo Freire, ainda procuro o meu próprio método; com o tempo, eu o encontrarei.” (Questionário com Educadores, Jefferson Barbosa, Cine Tela Brasil, Oficinas Tela Brasil). E André Gomes, que também atua na Fundação Criança de SBC, remete especificamente ao livro Pedagogia da Autonomia e ao fato de ter, a partir dele, percebido "o papel fundamental do educador".

O Pedagogia da Autonomia, citado por Gomes, é, sem dúvida, hoje o mais 
popular dentre os títulos de Freire. Atualmente encontra-se nas livrarias uma edição especial (comercializada por $\mathrm{R} \$ 10,00$ ) e em cuja capa encontra-se a inscrição: “edição especial 1.000.000 de exemplares". Se contei bem os zeros, estamos falando de um milhão de exemplares - isso dá a medida da popularidade e do quanto é fundamental essa obra de Freire.

Posso dizer que, ao longo dos anos, contribuí para essas estatísticas. Em todas as entidades pelas quais passei, nos meus dez anos de carreira, sugeri que este livro fosse comprado e distribuído aos educadores, coordenadores e gestores. Quando alguém me pede uma sugestão de leitura para entrar no universo da educação, sugiro sempre este livro. E sempre que possível promovo leituras reflexivas a partir dele. Segunda situação metodologicamente divertida (quiçá "inadequada"): esses quatro últimos jovens educadores que citaram Freire, foram meus alunos; fizeram um curso de formação para educadores e atuam há três anos sob minha supervisão. Como Marina Santonieri, que hoje é coordenadora do projeto no qual eles atuam, e que cita muito "Paulo Freire e metodologia democrática". É sempre bom constatar que os diálogos fazem eco, ao menos no discurso.

\subsection{Um outro caminho a partir de Freire - educação e comunicação}

Ana Paula Silva, educadora da Bem TV, afirma: "Paulo Freire é [o autor] que sempre norteou nosso trabalho", e afirma estar lendo também autores dos campos da educação e da comunicação.

Tanto a Bem TV como a Oficina de Imagens têm a educomunicação como metodologia inspiradora, e ambas integram a rede CEP de educomunicadores. Mas, finalmente, o que são exatamente a educomunicação e a rede CEP? E o que Paulo Freire tem a ver com isso?

Segundo o pesquisador Ismar de Oliveira Soares, coordenador do Núcleo de Comunicação e Educação da USP (NCE), se perguntarmos para qualquer uma das organizações que compõem a rede o quê caracteriza suas ações, a resposta seria apenas uma: "fazemos educação, pela comunicação, usando a mídia, com muita 
A expansão da educomunicação seria fruto de um novo momento histórico que apontava para a tradição latino-americana de colocar "os meios de informação a serviço dos interesses da população" -, e diversas entidades e movimentos sociais entenderiam que a "melhor forma de educar as gerações de crianças e jovens seria possibilitar que entendam como funcionam os sistemas de informação".

Segundo Soares, em pesquisa realizada pelo NCE/USP junto a especialistas de 12 países da America Latina, identificou-se a educomunicação como "o conjunto das ações inerentes aos processos, programas e produtos destinados a criar e fortalecer ecossistemas comunicativos em espaços educativos".

O conceito de "ecossistemas comunicativos" remete a Martín Barbero. Segundo Sayad, em texto também publicado na Revista do CEP, educomunicar integra diversas dimensões de um processo educativo, e

não é somente utilizar um computador ou uma câmera digital em sala de aula. É integrar educador e educando no desenvolvimento de produtos de comunicação; é permitir múltiplos olhares do plano pedagógico sobre a educação; é apropriar-se criativamente dos meios de comunicação; é integrar a voz dos estudantes ao "ecossistema comunicativo" (como definiu Barbero); e é, em última instância, melhorar a gestão do ambiente escolar com a participação dos educandos. (SAYAD, 2008, p. 6)

Para Soares, a educomunicação defende o diálogo, "com base em Paulo Freire, a maneira dialógica de 'estar juntos' no mundo, começando pela escola. Exalta, assim, virtudes como a capacidade de escuta e a disposição em favorecer e multiplicar as ocasiões de manifestação de todos os pólos vivos do processo educativo" (SOARES, I., 2008, p. 8)

Já Donizete Soares, do Projeto Cala a Boca Já Morreu, que também promove atividades inspiradas pela educomunicação, destaca em um texto intitulado “Educomunicação - o que é isto?”, que prefere pensar o diálogo como uma nova forma de convivência social. Para o autor,

fazer educomunicação ou realizar práticas educomunicativas, na medida em que isso quer dizer construir um novo discurso, é experimentar uma nova forma de convivência social. Aliás, educomunicação, do nosso ponto de vista é, antes de tudo, uma proposta de 
organização social essencialmente diferente desta em que estamos inseridos. (SOARES, D., 2008)

No texto de apresentação da entidade se destaca, em caixa alta e em diálogo com esta proposição, que todos participam de TODAS as etapas da realização. O Instituto Magneto Cultural, que se inspira na entidade, também destaca claramente a participação: "Eles podem e devem questionar, criticar, perguntar e, principalmente, criar". Assim como o Cinema Nosso: "todos, alunos e educadores, contribuem e participam de forma ativa na construção de um conhecimento coletivo". (Questionário com Cinema Nosso, 2009)

Há, nas diferentes entidades da EAP, uma atenção intuitiva à importância das instâncias democráticas de participação. Amadureceu-se, ao longo dos anos, uma percepção geral de que, apesar de alguns desses universos não terem contato direto com o cotidiano dos alunos, reflexos de sua filosofia de gestão são perceptíveis nos mais diversos âmbitos do processo de formação dos alunos.

Em um item do questionário especialmente dedicado ao tema, essa preocupação com a participação fica ainda mais evidente: $62,9 \%$ afirmam que a participação dos alunos é alta, sendo os alunos constantemente convidados a opinar. 21,4\% afirmam que a participação dos alunos é média. Apenas 8,6\% afirmam que os alunos participam pouco das tomadas de decisão. E 5,2\% afirmam que os alunos não participam da tomada de decisões.

Essa preocupação remete, historicamente, a um tipo de educação alternativa que ao longo do século 20 materializou-se em experiências conhecidas como escolas democráticas, nas quais a participação é levada a um paroxismo: os alunos têm liberdade de frequência e são constantemente convidados a opinar, em assembleias e conselhos populares $^{34}$.

Nas entidades que promovem a Educação Audiovisual Popular, a presença de assembleias ainda não é um fato totalmente comum, mas, de maneira geral, as instâncias de participação são diversas e essas práticas vêm se ampliando - conforme

${ }^{34}$ Como veremos nos subcapítulo 4.2 
constato a partir dos dados coletados no questionário. Como se vê no gráfico abaixo:

Gráfico 9 - Menções das Entidades à existência de instâncias de participação

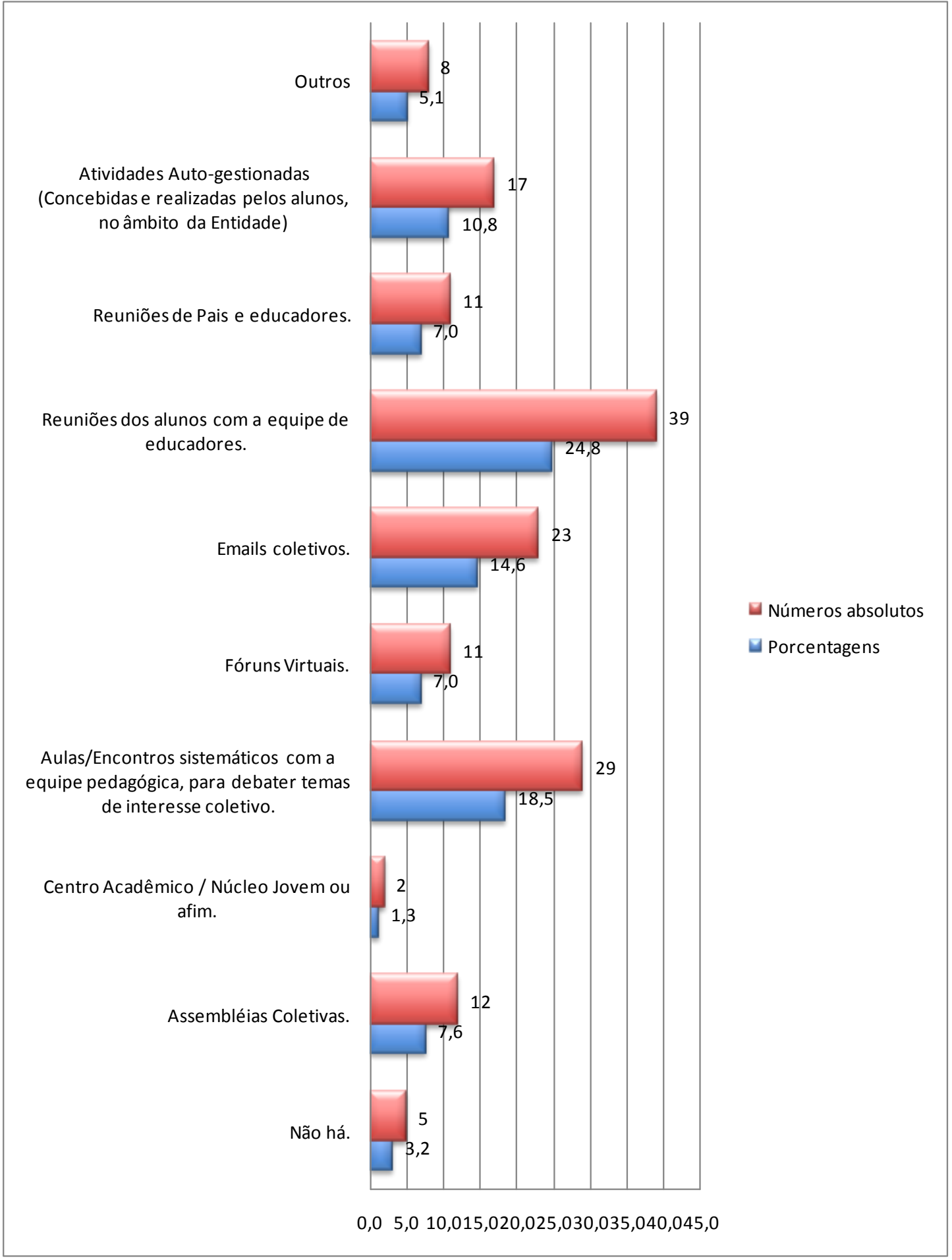

Fonte: Questionário com Entidades, 2009.

Essa percepção geral da participação como elemento central de uma gestão 
pedagógica é um grande diferencial da EAP, e será problematizado no Capítulo 4 (item 4.1).

Mas, dada a centralidade do tema da participação, talvez seja interessante fazermos um recuo maior no tempo, em busca dos principais autores e teorias que viram nesse aspecto um ponto fundamental para a transformação do universo escolar. Ainda que a referência mais citada seja Freire, e que a educomunicação também a promova, a valorização da participação é um elemento constante na história da educação alternativa. Entender por que ela promove mudança e está tão presente nos discursos, passa por uma compreensão histórica da evolução das práticas alternativas que, pouco a pouco, foram elevando o status diferenciado da participação como conceito.

\subsection{Participação, pedagogias alternativas}

Historicamente, quando surge a ideia de participação dentro da educação? Que conquistas, historicamente, a participação impulsionou?

Não creio que possamos afirmar a existência de algo como uma metodologia participativa. Existem, no entanto, dentro do amplo espectro de teorias educativas alternativas, também chamadas "Pedagogias Ativas", dois campos em que a participação é considerada ponto central e definitivo: a educação democrática e a educação libertária.

A educação democrática não se configura, exatamente, como um campo com limites definidos, e compartilha princípios e autores com a educação libertária, especialmente em sua genealogia. Além de autores e experiências dispersos no tempoespaço há mais de um século, a educação democrática materializa-se especialmente em escolas democráticas, nas quais, dentre outros procedimentos emancipatórios, a participação é levada a um paroxismo: os alunos têm liberdade para frequentar, ou não, as aulas e laboratórios; e realizam a co-gestão de instâncias diversas das escolas juntamente com a equipe pedagógica. 


\subsection{Educação democrática de que democracia?}

Sem um prelúdio que conceitue o termo, educação democrática ${ }^{35}$ remete livremente à Grécia, ao Iluminismo, às Repúblicas, à política partidária. Como filosofia (conjunto de estudos e conceitos $^{36}$ ), ou pedagogia (conjunto de doutrinas e métodos ${ }^{37}$ ), se constrói como um campo livre em eterna mutação: autores teóricos e educadores que escrevem de forma esparsa.

Como observam Bennis e Graves, a ideia de uma educação democrática também gera interpretações muito distintas, já tendo sido muito utilizada para mascarar abordagens autoritárias, que envolvem estruturas hierárquicas e percursos determinados para teoricamente formar

“[...] cidadãos de uma democracia”. Esse é o tipo de pré-concepção que embasa autores como o presidente da Universidade da Pensilvânia, Amy Gutmann, em seu livro Democratic Education (1999). Enquanto Guttmann usa o termo "educação democrática" para descrever o objetivo final de uma forma autoritária e basicamente pré-planejada de ensinar, nós acreditamos que a democracia e a liberdade podem ser a um só tempo o resultado de uma educação como os meios pelos quais ela ocorre.(BENNIS; GRAVES, 1996)

Os autores aqui tocam numa questão central e comum aos diversos autores e experiências estudadas: a ideia de que o processo educativo pode abarcar liberdade e democracia - visando não apenas resultados e conteúdos -, e com grande ênfase nos processos de aprendizagem dos próprios processos.

Para Singer, busca-se preparar os alunos para um contexto social onde todos os cidadãos possam participar das decisões relativas ao seu destino político, em diálogo tanto com o iluminismo como com o socialismo: "O ideal de democracia aqui pretendido é, sem dúvida, tributário dos princípios de liberdade, igualdade e fraternidade da Revolução Francesa, mas é muito marcado, também, pelas ideias do socialismo, tanto o que se poderia chamar de socialismo romântico de Rousseau quanto o socialismo científico de Marx". (SINGER, 1997)

\footnotetext{
${ }^{35}$ Vale lembrar que o termo democracia foi se desgastando pelo uso até chegar a designar o desenvolvimento da sociedade moderna.

${ }^{36}$ Filosofia: conjunto de estudos ou de considerações que tendem a reunir uma ordem determinada de conhecimentos em um número reduzido de princípios que lhe servem de fundamento e lhe restringem o alcance. (Ferreira, 1999, p. 905).

37 Pedagogia: Teoria e Ciência da educação e do ensino. Conjunto de doutrinas, princípios e métodos. (FERREIRA, 1999, p. 679).
} 
A democracia a que essa educação se refere, assim, é e não é a democracia grega, iluminista ou contemporânea. É, porque se trata, de fato, de uma formação que visa hoje, como na Grécia, preparar, em última instância, para a vida em uma sociedade democrática. E não é porque não é uma educação política, visando emular simplesmente uma futura vida política; é uma educação que prepara para todas as dimensões da vida em sociedade, por isso, vai além da educação política. É uma educação a partir de uma ascensão política libertária e democrática: aprender os sentidos de se aprender, para que este possa ser sempre um processo livre e autônomo.

As Escolas Democráticas, materialização mais destacada da educação democrática, são muitas vezes associadas ao movimento da Escola Nova que, segundo Singer, era fundamentalmente definido pela "descoberta da psicologia infantil e a crítica à escola tradicional, que aos poucos ia saindo das mãos da igreja". Aos poucos, os objetivos das Escolas Democráticas foram se diferenciando da Escola Nova, que pretendia formar homens capazes de produzir ativamente a partir da articulação do jogo como elemento educativo - enquanto as Escolas Democráticas "radicalizam a crítica à escola tradicional, incluindo nessa também a Escola Nova, que a seu ver abandonara as preocupações mais amplas com os ideais de uma sociedade democrática" (SINGER, 1997, p. 16)

O pensamento central e fundador para ambas seria de que a verdadeira aprendizagem ocorre espontaneamente, como já propunha o filósofo Jean JacquesRousseau, que "apostava na curiosidade infantil e deixava que ela conduzisse o processo de aprendizado, procurando reduzir ao mínimo o contato da criança com a sociedade, considerada a fonte de todo o mal". Buscava-se, enfim, atentar para o desejo da criança: "Os educadores que o sucederam mantiveram a ênfase na curiosidade infantil, mas deslocaram a questão sobre a fonte do mal - se é a natureza, como dizia Durkheim, ou a sociedade, como afirmava Rousseau - para a necessidade do respeito ao desejo da criança, tratando-a como indivíduo.” (Ibidem, p. 18)

Passou-se a enfatizar o desenvolvimento da individualidade da criança, estimulando a participação como meio para despertar o senso de responsabilidade, 
sem, contudo,

“[...] simplesmente inverter os pólos da educação tradicional e passar a permitir tudo o que até então foi proibido, ou negar por completo a ação de todos os agentes responsáveis por aquela educação. Trata-se de formular uma outra proposta de educação para a formação de cidadãos aptos a viver sob o regime democrático". (Ibidem, p. 19)

A sociologia, para a autora, teria percebido desde cedo a importância do projeto educativo de uma sociedade, a partir (dentre outros) de Émile Durkheim, que acreditava na prática da disciplina como meio para inculcar nela o espírito da disciplina, e cujo discurso seria sintoma "de um dispositivo pedagógico fundamentalmente disciplinar, não comprometido com ideal da autonomia de cidadãos livres, responsáveis e criadores”. (Ibidem, p. 24)

Durkheim acreditava que a disciplina não violenta a natureza da criança, e que simplesmente facilita sua normalização, de forma que o indivíduo acabaria naturalmente desejando ser disciplinado. Uma das principais ferramentas para alcançar tal estágio moral seria a penalidade, uma das várias antecipações da vida adulta transposta para o contexto escolar. (Ibidem, p. 34)

Uma crítica fundamental sobre o impacto do poder disciplinar sobre os indivíduos encontra-se na obra de Michel Foucault, que não cita diretamente Durkheim, mas não se furta ao uso de seus conceitos. Foucault aponta a escola como um dos principais espaços institucionais onde atua o poder disciplinador, ao lado de prisões, hospitais e manicômios, "onde o poder disciplinador se faz presente, produzindo indivíduos dóceis e eficientes". (Ibidem, 40) Os autores e as Escolas Democráticas questionam esse dispositivo disciplinar, buscando superá-lo sem reproduzi-lo de maneiras camufladas.

Segundo Singer, não se trataria mais de "obter renúncias a partir de sacrifícios, como na Idade Média, e sim produzir uma individualidade obediente, utilizando-se das técnicas disciplinares", obtendo docilidade e eficiência, não apenas punindo, mas vigiando, corrigindo, reeducando ${ }^{38}$.

\footnotetext{
38 “Esses métodos que permitem o controle minucioso das operações do corpo, que realizam a coerção constante de suas forças e lhes impõem uma relação de docilidade-utilidade, são o que podemos chamar "as disciplinas". Muitos processos disciplinares existiam há muito tempo: nos conventos, nos exércitos, nas oficinas também. Mas as disciplinas se tornaram, no decorrer dos séculos XVII e XVIII, fórmulas gerais de dominação”., (FOUCAULT, 2008a, p. 118)
} 
Mas se o exercício do poder gera controle, a partir da vigilância e da classificação ele também produz reações, “que são seu oposto irredutível; ou seja, o mesmo movimento que produz a dominação, produz também resistência à ela" (Ibidem, 43). Para Singer, as Escolas Democráticas atuam a partir dessa reação, como "um saber não capturado pelo poder e, portanto, como uma possibilidade de resistência. Resistência ao controle da vida mediante a reivindicação da autonomia das crianças sobre seus próprios corpos, suas necessidades e sua felicidade, recusando a aplicação dos mecanismos dominantes de sujeição". (Ibidem, 47)

As Escolas Democráticas atuam nesse domínio como as OSCIPs e outras entidades que promovem a Educação Audiovisual Popular (com raras exceções). Ambos os contextos, com suas práticas e saberes ainda não capturados pelo poder, são células de sobrevivência onde ocorrem, de fato, laboratórios que testam os limites da ciência pedagógica, e cujas contribuições têm alto valor social. Lutar por uma aproximação entre as conquistas dessa experiência e instâncias de poder que as possam ampliar - a despeito de qualquer receio de ela assim seja neutralizada -, é uma das principais motivações dessa pesquisa.

\section{*3.4.1 SISIFIANAS, OU EM BUSCA DE UMA DEFINIÇÃO}

Segundo Dana Bennis e Isaac Graves, em artigo publicado no site www.democraticeducation.com, houve um crescimento no interesse pela abordagem democrática desde os anos 90, levando à atual presença conhecida de mais de 200 escolas democrática em 29 países do mundo, que atenderiam cerca de 15.000 estudantes. $^{39}$

Para Bennis e Graves, “a própria natureza e dinâmica da educação democrática a torna difícil de definir. Não há uma definição "aceita" do que exatamente significa educação democrática (e na nossa opinião, esperamos que nenhuma autoridade jamais se proponha a criar tal definição)".(BENNIS; GRAVES, 1996a, p. 1). Tomando como empreitada inviável definir a educação democrática, os

\footnotetext{
${ }^{39}$ No site dos autores há uma catalogação de escolas, recursos, cooperativas e organizações que dedicam-se à prática da educação democrática.
} 
autores buscam então apresentar suas manifestações, citando algumas características básicas da experiência prática em andamento, propostas por diferentes institutos e escolas democráticas:

O Instituto para a Educação Democrática sediado em Israel, enuncia: "Aderir aos direitos humanos dentro do contexto escolar e gerir a vida escolar a partir das bases de procedimentos democráticos". [...] A Sudbury Valley School, uma escola norte-americana das mais perenes, cita as seguintes características: direitos individuais, democracia política e oportunidades iguais. Matt Hern, diretor da Purple Thistle Centre de Vancouver, descreveu nove características: currículo não obrigatório, avaliação qualitativa, freqüência optativa, foco no desenvolvimento emocional e social, atividades não hierárquicas, amplas interpretações de aprendizagem, e a importância de brincar (BENNIS; GRAVES, 1996b, p. 1)

Como vimos anteriormente, ao delimitar o corpus de sua pesquisa, dedicada a experiências pioneiras e de destaque em que se criaram verdadeiras "Repúblicas de crianças" - como sugere o título da pesquisa -, Singer propôs como aspectos característicos das Escolas Democráticas “a presença de assembleias escolares, nas quais todos os membros da comunidade têm o mesmo poder de voto e onde são tomadas todas as decisões relativas ao cotidiano (...) e de aulas opcionais, que mantêm o respeito à liberdade de o aluno decidir se deseja ou não assistir às aulas e acompanhar os cursos". (SINGER, 1997, p. 15)

As características citadas não são idênticas, mas todas as entidades e autores (citadas por Bennis e Graves e Singer) dialogam entre si. Como se tais princípios pudessem pertencer a uma mesma escola. Ficam ainda mais evidentes as características filosóficas e pedagógicas da educação democrática: seus princípios filosóficos foram enunciados por Rousseau e atualizados por vários autores, e versam sobre liberdade e participação; e suas teorias e práticas pedagógicas são atualizadas e recriadas cotidianamente de maneira criativa e positivamente "desobediente" com relação a esses princípios.

Como alerta Singer, mesmo o uso do termo "escolas democráticas" também não é universal. Para definir o corpus de sua pesquisa, dentre possíveis terminologias, tais como "escolas românticas", "pedagogia centrada no aluno", "escolas libertárias", “escolas livres", "escolas democráticas”, a autora optou pelas duas últimas, segundo 
ela, “mais abrangentes e utilizadas pelos seus próprios agentes" (Ibidem, p.15).

Michael Apple e James Beane, em um artigo que abre o volume por eles organizado sobre o tema, fazem uma reflexão sobre a ontologia das Escolas Democráticas: a origem do termo "democracia", sua concepção contemporânea e o papel político da educação para a transformação social.

Apple e Beane também se alinham às características descritas por Singer, Bennis e Graves: as preocupações centrais das Escolas Democráticas seriam, resumidamente, despertar a percepção dos alunos quanto às condições das quais a democracia depende para se desenvolver, e permitir sua ampliação por meio da educação. Dessa forma, elas visariam “criar estruturas e processos democráticos por meio dos quais a vida escolar se realize. (...) E criar um currículo que ofereça experiências democráticas aos jovens” (BEANE; APPLE, 1997a, p. 16)

Francisco Codello, em seu livro A Boa Educação, optou por outro termo e outro recorte de fronteira: a "educação libertária", ou "anarquismo educativo", que ele considerava "uma teoria pedagógica e um movimento educativo".

Dentre os autores pesquisados por Codello - como Godwin e Dewey, Tolstói e Neill -, haveria uma forte convicção de que não há liberdade possível sem reações concretas de liberdade, sem uma integração entre respeito e especificidade individual, e uma relação social e igualitária ${ }^{40}$ (CODELLO, 2007a, p. 20). É interessante como Tolstói e Neill, estudados por Singer como precursores da "educação democrática", são considerados pioneiros também da dita educação libertária.

Bennis e Graves alertam que outros membros desse universo, "de funcionários a familiares dos alunos", podem ter outras definições ainda mais distintas destas. Por fim, eles arriscam uma definição, bastante ampla e em total acordo com Singer: "A Educação Democrática é uma abordagem educacional fundamentada pelo respeito pelos direitos humanos em uma leitura ampla da aprendizagem, na qual pessoas

\footnotetext{
${ }^{40}$ Para Codello, muitos educadores e teóricos do anarquismo conceberam estratégias originais e pioneiras que foram incorporadas por outros pensadores e suas escolas, sem que nunca essas ideias fossem reconhecidas como próprias do anarquismo.
} 
jovens têm a liberdade para organizar suas atividades diárias, e há igualdade e um processo decisório democrático envolvendo pessoas jovens e adultas." (BENNIS; GRAVES, 1996, p. 1)

\section{*3.4.2 ESCOLAS DEMOCRÁTICAS}

Poderíamos começar de outra maneira. Mas Summerhill é certamente a mais notória, controversa e mundialmente famosa escola democrática do mundo. Fundada pelo psicólogo Alexandre Sutherland Neill em 1921, na cidade de Sussex, no sul da Inglaterra, Summerhill é também a mais perene escola democrática: ainda está em pleno funcionamento, sob a gestão da filha de Neill, Zoe ${ }^{41}$.

Como sintetiza Neill,

Summerhill governa-se pelo princípio da autonomia, democrático em sua forma. Tudo quanto se relacione com a sociedade, com o grupo, a vida, inclusive as punições pelas transgressões sociais, é resolvido por votação nas Assembleias Gerais da Escola, nas noites de sábado. Cada membro do corpo docente, e cada criança, independente da idade que possa ter, apresenta seu voto. Meu voto pesa tanto quanto o de um garoto de sete anos. (NEILL, 1966, p. 41)

Como conceitua a educadora Helena Singer: trata-se de uma verdadeira "república de crianças", na qual se verifica também a presença "de aulas opcionais, que mantém o respeito à liberdade de o aluno decidir se deseja ou não assistir às aulas e acompanhar os cursos”. (SINGER, 1997, p. 15)

O fato de as regras escolares serem definidas por todos não significa uma “anulação do bom senso". O processo de diálogo e construção das regras é, em si, um processo altamente pedagógico, e as regras são pensadas também como forma de estabelecer os limites de um "bom senso coletivo". Como comenta Neill,

Em Summerhill, as crianças só podem ir ao banho de mar quando está presente um salvavidas para cada seis delas. Regras ditadas pelas próprias crianças nas assembleias gerais da escola. Não há leis, contudo, para a escalada de árvores. Subir em árvores faz parte da educação da vida, e proibir todas as empresas perigosas seria fazer da criança um covarde. (NEILL, 1966, p. 19)

\footnotetext{
${ }^{41}$ Como se pode atestar em uma rápida visita ao site www.summerhillschool.co.uk.
} 
O sistema de gestão das assembleias é simples: autogestão, que permite aos alunos exercitar constantemente o diálogo e o bom-senso:

\begin{abstract}
Quem quer que tenha um agravo, uma acusação ou uma sugestão a fazer, pode fazê-la, e quem tem uma nova lei a propor, apresenta-a.[...] Habitualmente, o veredicto da Assembleia da Escola é aceito pelo culpado. Entretanto, se um veredito é inaceitável, o acusado pode apelar, e nesse caso, o presidente trará o assunto novamente à consideração, ao final da Assembleia. Nessa apelação, o assunto é considerado com maior empenho, e geralmente, o veredito é abrandado, diante da inconformação do acusado. As crianças compreendem que, se o acusado sente que sofreu injustiça, há muita probabilidade de que realmente a tenha sofrido. (NEILL, 1966, p. 45)
\end{abstract}

O texto de apresentação do site dá a medida da radicalidade da experiência, e do caráter central que a participação tem em um contexto amplo de formação voltada para a autonomia e a liberdade:

Em Sumerhill, seu filho teoricamente pode nunca entrar em uma aula - ele têm esse direito. A equipe não irá persuadi-lo ou importuná-lo sobre as aulas. No entanto, é claro, nós sempre seremos realistas quanto ao futuro de um aluno, e certamente iremos abordá-lo para oferecer ajuda se ele estiver lutando contra aspectos de seu desenvolvimento. (Website da Summerhill School) $)^{42}$ )

O médico polonês Janus Korczac, em iniciativa pouco anterior a Summerhill, fundou o Lar das Crianças ${ }^{43}$ em 1912 em Varsóvia, na Polônia. Sob a mesma égide de liberdade e participação, o Lar possuía duas instituições nas quais as crianças experimentavam a participação e a gestão do orfanato: um Tribunal, que objetivava proteger todo habitante do orfanato e seus direitos. E um Parlamento, "composto de vinte deputados eleitos, Korczac como presidente honorário e um secretário" e que decidia sobre todas as regras da instituição. O Lar das Crianças contava ainda com dois jornais, que eram distribuídos e recebiam cartas de crianças de escolas de toda a Polônia. (SINGER, 1997, p.84)

O ambiente participativo das Escolas Democráticas como Lar das Crianças e Summerhill era e é o cenário perfeito para a experimentação e implantação de metodologias nada ortodoxas para abordar os conflitos do cotidiano, e se promover uma educação através do afeto: "Há, como é natural, muito amor nesse mundo. Se não fosse assim, poderíamos desesperar da humanidade. Cada pai e cada educador

\footnotetext{
${ }^{42}$ Acessado em do Site www.sumerhill.co.uk em 02.02.2008

43 A história do Lar das Crianças foi imortalizada no cinema e tornou Korczac mundialmente famoso. "Korczac", traduzido no Brasil como "As 200 crianças do Dr. Korczac", foi dirigido em 1990 pelo cineasta polonês Andréj Wajda, e relata a trágica morte do médico nas câmaras de gás de Treblinka, junto de suas crianças.
} 
deveriam tentar descobrir, seriamente, esse amor em si próprio." (NEILL,1966, p. 135)

Em seus escritos, Neill destaca aspectos variados da sua experiência à frente de Summerhill, muitas vezes a partir de relatos inspirados em histórias reais - o livro de Garroux, citado pouco antes, apresenta formato semelhante.

A partir de alguns relatos é possível vislumbrar algumas características da sua radical visão educativa em que, grosso modo, não há receitas, regras sociais ou de conduta óbvias - apenas pedagoDia:

Quando um garoto foi atrevido em relação ao nosso açougueiro, eu disse aos alunos, numa Assembleia Geral, que o açougueiro se havia queixado a mim. Mas penso que teria sido melhor se o açougueiro tivesse dado um soco no ouvido do garoto. $O$ que as pessoas geralmente chamam "maneiras" são coisas que não valem a pena de ensiná-las. (NEILL, 1966, p. 180)

Se estou pintando uma porta e Robert atira lama na minha pintura fresca, eu o xingo vigorosamente, porque o garoto está conosco há muito tempo e o que lhe diga "não" tem importância. Suponhamos, porém, que Robert tivesse chegado recentemente, vindo de uma escola odienta, e seu gesto representasse a tentativa de luta contra a autoridade: eu o ajudaria a atirar a lama porque sua salvação seria mais importante do que a porta. Sei que devo estar do lado dele enquanto expande seu ódio até esgotá-lo, a fim de que de novo se faça sociável. Não é facil. (Ibidem, p. 112)

Podemos depreender dos relatos de Neill que ele, como psicanalista, tinha uma grande preocupação com o desenvolvimento emocional dos alunos. Valorizava, mais do que tudo, formar pessoas capazes de se relacionar no mundo, respeitando e dialogando constantemente com o universo do outro:

(Em Summerhill) Cada qual é constantemente compelido a ver o ponto de vista dos demais. Não se pensa, sequer, que umas das nossas crianças pudesse rir de um gago ou zombar de um aleijado, duas coisas que as crianças das escolas estritas muitas vezes fazem. Os meninos que dizem "por favor", "obrigado", "desculpe-me, senhor", podem ter, realmente, bem pequena atenção verdadeira para com os outros. Maneiras são uma questão de sinceridade. (NEILL, 1966, p. 182-183)

No lar médio, se uma criança quebra um prato, o pai ou mãe armam barulho, tornando o prato mais importante que a criança. Em Summerhill, se uma camareira ou uma criança deixa cair uma pilha de pratos, eu nada digo, minha esposa nada diz. Acidentes são acidentes. Mas se a criança pede um livro emprestado e o deixa lá fora, exposto à chuva, minha esposa se zanga, porque livros, para ela, têm muita importância. Em tal caso, eu, pessoalmente, sou indiferente, pois os livros para mim têm pouco valor. Por outra lado, minha esposa parece vagamente surpreendida se eu faço um barulho a propósito de um formão estragado. Dou valor a ferramentas, mas, para ela, as ferramentas pouco representam. (Ibidem, p. 17)

O mais importante, por fim, seria despertar a sensibilidade dos alunos para as 
características inerentes à convivência, não apenas na escola, como na sociedade. Neill não tinha como expectativa maior formar alunos capazes de desempenhar carreiras de sucesso do que formar pessoas capazes de respeitar as idiossincrasias das demais - destacando-se, não por seu acúmulo de saberes, mas por sua forma sensível e verdadeira de lidar com eles. Como essa outra história relatada por Neill ilustra:

\begin{abstract}
Quando Jack, depois de deixar Summerhill, foi para uma fábrica, viu que o homem que estava incumbido da distribuição de porcas e parafusos aos operários estava sempre de péssimo humor. Jack pensou no caso e chegou à conclusão de que havia uma causa para aquilo. Os trabalhadores gritavam para o homem: "Olá, Bill, atira daí umas porcas Whitworth de meia polegada!". Bill, entretanto, usava paletó e colarinho, e Jack percebeu que ele se sentia superior aos operários metidos em macacões, e que seu mau humor nascia da falta do respeito a que se julgava com direito. Assim, quando precisava de material, Jack ia para junto de Bill e dizia: "Com licença, Sr. Brown, preciso de parafusos e porcas. [...] Chamo a isso excelente exemplo de maneiras que a vida em comunidade dá às crianças - o pensar e sentir pelos outros. (Ibidem, p. 182-3)
\end{abstract}

Durante muitos anos, Neill trocou uma farta correspondência com o psicanalista Wilhelm Reich. Influenciado pelo frescor da psicanálise, realizou durante décadas atendimentos individuais com os alunos, basicamente aplicando processos terapêuticos bastante heterodoxos - como os relatos acima sugerem. Neill não tinha medo de experimentar, pedagogicamente, o tempo todo. E experimentava, sempre, na fronteira do afeto: "Estamos levando as crianças por um caminho que as fará tolerantes, mostrando-nos tolerantes para com elas." (NEILL,1966, p. 115)

Os relatos de Neill estabelecem claro diálogo com a visão de Freire, com os acordos heterodoxos de Garroux ("Tia Dag") relatados no início do Capítulo, e com práticas realizadas pontualmente por alguns educadores de entidades da EAP, como $\mathrm{gUi}^{44}$ Mohallem.

O educador, que atuou no Instituto Criar, na Escola Livre de Cinema e Vídeo de Santo André e em diversos outros projetos, não possui o mesmo perfil de líder de entidade, mas desenvolveu estratégias bastante similares às de Neill e Tia Dag, uma atuação pautada à luz de Freire: "Ensinar exige alegria, esperança e querer bem aos educandos".

Quando detectou em uma turma de alunos um forte episódio de preconceito

\footnotetext{
${ }^{44} \mathrm{O}$ educador, que também é fotógrafo, utiliza invariavelmente a grafia gUi, e procuramos respeitar aqui sua escolha.
} 
contra um aluno homossexual de outra turma e os alunos que conversavam com ele,

Mohallem realizou uma atividade que lembra os acordos heterodoxos de Neill e Tia

Dag. Exibiu um vídeo que propõe uma reflexão sobre preconceito, de maneira mais abstrata, e foi desconstruído o preconceito sexual ao demonstrar que, conceitualmente, todos os preconceitos são iguais. Ainda, sugere como a fronteira do afeto, quando fragilizada com bom senso, pode potencializar uma profundidade reflexiva ímpar no grupo, na qual o universo pessoal do educador torna-se algo indissociável de sua prática. $\mathrm{O}$ relato é longo, mas vale à pena conhecer a experiência em sua riqueza de detalhes:

Um dia, estávamos fazendo uma atividade em sala de aula, e zoaram um aluno com um termo que não entendi. [...] Até que eles explicaram que estavam chamando o cara de "veado", falando de outro "veado", mas de um jeito pejorativo, e aí eu disse: "Espera aí, vamos conversar". E eles: "Não queremos conversar disso não". Então vamos fazer uma roda: "Quem já sofreu preconceito aqui?" Aí foi muito legal, porque eles começaram a abrir o jogo e um aluno disse: "Olha, eu não tenho nada contra, se não chegar perto de mim e nem pegar no meu 'pau". E eu retruquei: "Porque você acha que o cara que é gay, ele vai chegar perto de você e te atacar? Você ataca toda mulher que você vê? E só porque ele deseja homem, ele vai te atacar?" E eu comecei a questionar: "Olha como você é preconceituoso." Então um menino contou uma história: toda vez que eles iam sair para beber ou viajar, deixavam toda a bebida e a droga com um loirinho, porque ele não era revistado pela polícia. Então, entre os amigos da periferia, tinha um loiro, e era com ele que ficava toda a droga, porque ele nunca era revistado. Os negros eram revistados. Os negros e pardos. [...] E aí eu falei: "Tenho um filme pra passar, se vocês quiserem. É um filme que vai discutir um pouco o preconceito racial, mas eu acho que é mais abrangente". Na hora de se manifestar sobre o preconceito com a sexualidade, disseram: "Eu realmente acredito que a pessoa nasce ou não gay, assim como nasce negro ou não". O negro sofre preconceito na rua, mas, em casa, ele não sofre preconceito por ser negro; com o gay é o contrário, ele pode até não sofrer preconceito na rua, mas quando chega em casa, aí é que ele sofre mais preconceito. [...] Então, na aula seguinte, que era de vídeo, coloquei um filme chamado "Blue Eyes". Era um filme preto e branco. O que eu fazia? Colocava o filme, ele falava alguma coisa e eu pausava. E prosseguia: "O que ele falou aqui?"'[...] E os alunos recontavam o filme entre si. O filme tinha uma hora, e em uma aula de duas horas, vimos o filme pela metade. Acabou, e eu disse: "Temos a opção de parar de falar disso e fazer outra coisa; ou então continuamos a ver o filme. O que fazemos na aula que vem?" O importante foi eles terem assistido o filme; e foi uma escolha dos alunos também. Eu sempre abria para eles essa possibilidade, de que era uma proposta, mas sabia que podia dar errado. Eles disseram no final da aula: "Vamos ver mais!", e então assistiram o filme inteiro comigo desse jeito. Depois disso, o preconceito diminuiu bastante e, na hora que eu contei para eles que eu era gay, eles falaram: "Ah, então foi por isso que insistiu tanto naquele assunto?" Eles entenderam, e eu fiquei até meio ofendido; não ofendido, mas meio flagrado nessa hora. Mas hoje eu entendo que foi bom ter sido flagrado. No fim, eles entenderam uma lição importantíssima: de que a subjetividade do professor vai para a sala de aula. Então vou discutir mais as minhas questões, e isso é normal em qualquer profissão, mas na de professor, ainda mais. Se a liberdade é uma delas, essa questão da sexualidade e do preconceito era também importante. (Informação verbal obtida em 2009

Neill, Tolstói e Garroux possuem uma característica que os aproxima: são educadores cuja atuação praticamente se confunde com a própria metodologia das entidades que lideram. Alguém poderia questionar se uma educação baseada em 
princípios afins não estaria excessivamente calcada em figuras carismáticas e de natural talento - se não, seria quiçá uma proposta um tanto "messiânica".

Baseada em minha experiência pessoal, o que educadores como Tolstói, Neill e Garroux experimentaram - e inclusive Mohallem, que não é líder de entidade nem possui o mesmo perfil dos demais - evidencia aspectos decisivos que podem ajudar a orientar a formação das próximas gerações de educadores. Tanto para formar quadros para experiências alternativas quanto para as escolas formais hegemônicas: a necessidade de se jogar fora os manuais que determinam como se deve ou não agir/reagir, permitindo a si mesmo a liberdade de usar de alguma intuição para, em virtude dos desafios, integrar as diferentes fontes de reflexão e experiência que se possui.

\section{Estratégias}

Neste Capítulo, busco sintetizar os dados levantados durante a pesquisa para apresentar um panorama dos meios pedagógicos e estratégias de gestão pelos quais os diversos projetos pesquisados promovem a EAP.

Apresentar os meios pelos quais cada entidade promove, individualmente, suas atividades seria uma estratégia injustificadamente enciclopédica; optei então por sistematizar o conjunto dos meios e instrumentos utilizados pelas experiências de promoção da EAP e construir formatos sintéticos - "oficinas imaginadas" ou "tipos ideais"-, a partir dos quais seja possível visualizar as estratégias utilizadas.

Para tal empreendimento, mobilizei dados captados através de todos os instrumentos criados para a pesquisa e, especialmente, elementos que vêm da minha experiência pessoal, que, nesse caso, fornece um sem-número de informações coletadas informalmente ao longo da última década - nesta que é justamente a área na qual atuo diretamente. 
São apresentados também alguns dados mais pessoais sobre dois projetos cuja idealização e gestão pedagógica realizei ${ }^{45}$, já dentro do escopo desta tese, e nos quais logrei experimentar estratégias pedagógicas e de gestão bastante específicas. Em cada projeto havia espaço para a experimentação de apenas um arcabouço específico de tais estratégias-piloto, deveras longe da implantação de algo semelhante ao que eu consideraria um projeto ideal. Assim, não se justificaria uma análise mais destacada/isolada de tais projetos, senão em uma perspectiva transversal e integrada à experiência das demais entidades.

De todo modo, é importante destacar que, dentre os profissionais citados, há alguns que atuaram comigo diretamente nestes projetos ${ }^{46}$, fazendo com que, nesses casos, seu diálogo com as temáticas da tese seja mais direto e perceptível.

$\mathrm{Na}$ primeira parte deste capítulo, apresento as principais estratégias pedagógicas utilizadas pelas entidades no que tange à gestão, ao espaço, à adesão dos alunos e sua interação com a equipe pedagógica.

Construí também três perfis de oficinas a partir dos critérios de duração e carga horária. Analiso na segunda parte deste Capítulo uma síntese das práticas pedagógicas em cada um desses perfis.

\subsection{Pedagogicidades}

\subsection{1... DA GESTÃO}

Em muitas entidades, as funções de gestão ${ }^{47}$ são realizadas por jovens gestores ou educadores que se tornaram gestores, e que - a partir da visão de quem está ou

\footnotetext{
${ }^{45}$ Escola Livre de Cinema e Vídeo de Santo André e Oficinas Tela Brasil (OTB). Ambas integram o mapeamento.

${ }^{46}$ Atuaram nos projetos: Mônica Cardella (ELCV), Marina Santonieri (ELCV e OTB), Henry Grazinoli (ELCV e OTB), GUi Mohallem (ELCV e OTB), Leonardo Cubas Gusmão, Wagner Klebson, Jefferson Santos, Jefferson Barbosa (OTB).

${ }^{47}$ Quando se fala aqui em gestão - no âmbito específico das entidades -, refere-se a todos os processos de gerenciamento: pessoas, departamento financeiro, secretaria de alunos, comunicação, coordenação educacional, pedagógica e direção.
} 
esteve em campo - vem recriando o ofício da gestão.

Uma entidade especialmente preocupada com as características decisivas da gestão é a Associação Imagem Comunitária (AIC), ONG atuante, desde 1993, em Belo Horizonte. Um primeiro aspecto notável no que diz respeito a esse tema é o desconforto com a hierarquia típica de ambientes tradicionais de trabalho. Como observa Alexia Melo, jovem gerente de projetos da AIC: "É um lance de você também deslocar esse papel, e eu falo muito com os meninos: 'olha, eu não tive curso para isso; minha coisa veio de uma teoria, mas muito mais da prática, da reflexão sobre a prática, e eu estou aprendendo a fazer gestão de projeto enquanto se faz a gestão". (Informação verbal de Melo, 2009)

A gestão é vista não como um sistema fechado, mas um elemento de ligação e organização que reflete a sensibilidade do gestor e tem implicações em todas as instâncias do projeto.

A AIC é uma das entidades (são 12, no total) que realizam Assembleias e Conselhos com os alunos - em diálogo direto com a experiência das Escolas Democráticas (ED).

No entanto, se nas ED as assembleias possuem um caráter amplo, incluindo aspectos específicos da gestão da entidade, o Conselho de Mídia Jovem da AIC nasceu com um enfoque mais voltado ao debate de temas de interesse dos jovens, como educação midiática, articulação, políticas públicas, e de outros "temas que eram pertinentes para serem jogados no espaço público. E um grupo de análise de linguagem, de discutir linguagem”. (Informação verbal de Melo, 2009)

Melo observa ainda que a alta rotatividade de jovens participantes das reuniões (cerca de 80) consistia em grande desafio, uma vez que sempre nas reuniões havia jovens com diferentes níveis de entendimento. (Informação verbal de Melo, 2009)

A Oficina de Imagens, de Belo Horizonte, também promove Assembleias 
Anuais, mas voltadas exclusivamente aos associados, profissionais "da casa", membros do conselho editorial, etc. Como no caso da AIC, a Assembleia tem um caráter formativo e apresenta foco especial na promoção do diálogo sobre temas que são prioridades transversais e cuja análise pode auxiliar a todos - sendo que, nesse caso, não participam diretamente os alunos do projeto:

Há uma assembleia anual sempre no início do ano; às vezes acontece alguma assembléia extraordinária. A assembléia é um espaço que reúne também os associados, os conselheiros. Procuramos dar prioridade à formação coletiva, com temas que são prioridades para qualquer projeto, por exemplo: temas sobre direitos humanos, sobre mídia, comunicação, e políticas da juventude, que são temas transversais. Em todas as ações, tentamos priorizar esses encontros, o que não é nada fácil, por questão da agenda de projetos, que é muito "apertada": temos mais "ação" do que tempo e dinheiro, isso faz com que a formação fique de lado, porque não dá para planejar oficina de manhã e fazer formação de equipe ao mesmo tempo.

Informação verbal de Paula Kimo obtida em 08 de maio de 2008)

\title{
Já o Instituto Criar de TV, Cinema e Novas Mídias (IC) implantou
}

recentemente um Conselho de ética, consultivo (que não decide, sugere) em que representantes de todas as instâncias da entidade participam. O Conselho teve como objetivo sanar os conflitos oriundos de alguma falta de comunicação direta entre a diretoria e os alunos. Como comenta Fiabane:

\begin{abstract}
Nesse comitê de ética estão presentes os jovens, a família, aliados sociais, parceiros, representantes de funcionários, de diretoria. Procuramos fazer um espaço bastante democrático para começarmos a traduzir melhor o que acreditamos e, ao mesmo tempo, ter tranquilidade de saber que nos comunicamos bem com aqueles que estão aqui dentro, e a todos os membros desta "família" quais são os nossos valores [...] Foi uma iniciativa da superintendência motivada pela observação de uma série de incompreensões que levavam a muita insatisfação por parte de todos. As decisões eram tomadas baseadas em uma série de decisões e argumentos, e até a outra ponta, elas acabavam chegavam totalmente transformadas, o que gerava um problema de comunicação e uma insatisfação, um clima organizacional que não era bacana. Então decidimos finalmente parar com esse "telefone sem fio", e democratizar o âmbito das decisões[...] E não seria por meio de voto; seria baseado nos diferentes relatos e pontos de vista levantados sobre um determinado assunto. (Informação verbal de Danielle Fiabane, 2009)
\end{abstract}

A AIC vem buscando também experimentar as fronteiras de uma possível gestão compartilhada, ou democrática, através, por exemplo, de conselhos gestores (em que os alunos praticavam a autogestão), que foram implantados de maneira experimental em um projeto voltado à formação de jovens para o empreendedorismo. A prática desses conselhos vem estimulando uma reflexão sobre a coerência entre as práticas da entidade como um todo:

Esse projeto foi um tubo de ensaio de como trabalhar a representatividade, e de participação, porque organizávamos ações grandes, pelo fato de que trabalhávamos em 18 escolas simultaneamente. E na verdade, ao mesmo tempo em que fomos ensaiando isso no processo do projeto, o que eu percebia era que isso ía se espelhando na gestão da ONG. E nos dávamos conta de que em um coletivo institucional tomávamos iniciativa de fazer algo em uma ponta, mas não na outra. Isso de ter coerência é uma via de 
mão dupla: às vezes algumas coisas que chegam para a gestão institucional como um todo da ONG vêm dessa relação, do contato com o jovem numa ponta. (Informação verbal de Alexia Melo, 2009)

De fato, não parece funcional criar instâncias de participação sem que exista alguma coerência simétrica no âmbito da gestão mais ampla. Tampouco criar e simplesmente entregar esse tempo-espaço aos alunos. Se no mundo das escolas democráticas, crianças de 6 anos de idade são estimuladas a tomar decisões e dedicar seu tempo às atividades que mais as interessam, nossos alunos, em mais de 10 anos de vida escolar tradicional, raramente foram estimulados da mesma forma. E, como pude descobrir "na pele", isso tem grandes implicações na forma como os alunos lidam com a liberdade e o espaço de expressão oferecidos.

Em dezembro de 2006 fui convidada a realizar uma experiência-piloto (já dentro do contexto da pesquisa para a redação desta tese) de implantação de aspectos ligados à educação democrática na ELCV - Escola Livre de Cinema e Vídeo de Santo André $^{48}$, onde foram implantadas práticas como assembleias e gestão participativa de recursos e regras ${ }^{49}$.

O planejamento pedagógico da ELCV foi, durante 18 meses, construído pela coordenação em parceria com os aprendizes, em encontros quinzenais chamados de Nureflex: Núcleo de Reflexão Pedagógica. Durante esse período, os aprendizes da escola tomaram as principais decisões relativas aos conteúdos trabalhados, disciplinas adequadas, exercícios e contratação de professores e convidados, além de regras de convívio e congêneres.

No segundo semestre de 2007 foi implantada efetivamente a fase I da experiência, em que propus a formalização dos Nureflex como encontros sistemáticos

\footnotetext{
${ }^{48}$ A Escola Livre de Cinema e Vídeo de Santo André foi fundada em agosto de 2001, e é um aparelho público, vinculado à Gerência de Formação da Secretaria Municipal de Cultura da cidade. Integra um conjunto de Escolas Livres de Artes, criadas em diferentes momentos dos dois mandatos do prefeito Celso Daniel, assassinado em janeiro de 2002. É importante compreender o contexto das políticas culturais implantadas em Santo André, pois se trata de terreno extremamente fértil à implantação de experiências avançadas de ensino de artes. Foram mais de 15 anos quase ininterruptos de gestões municipais e do Legislativo pautadas pela forte agenda de políticas culturais do Partido dos Trabalhadores. A herança política de Celso Daniel ainda é muito forte, e garante a manutenção constante e sempre reciclada - caso raro no país - de políticas públicas de formação cultural implantadas há mais de quinze anos. Os coordenadores são estimulados a inovar, e as escolas acabam tornando-se laboratórios vivos de metodologias de tendência democrática.

${ }^{49}$ Em janeiro de 2007 foi apresentado um primeiro projeto de reformulação da gestão pedagógica da escola, cuja implantação teve início em fevereiro de 2007. Nesse momento, a terceira turma de alunos da escola já havia cursado um semestre, tendo, portanto, ainda 1 ano e meio de aula antes do término das atividades obrigatórias ( 2 anos). A fase I da experiência-piloto na ELCV compreendeu essencialmente essa etapa, entre janeiro de 2007 e junho de 2008 , acompanhando a formatura dessa turma de alunos.
} 
entre alunos e coordenação, para a realização de debates constantes sobre as estratégias da escola.

Os encontros eram inicialmente semanais, e depois se tornaram quinzenais. Eram inicialmente mediados por mim, e aos poucos, os alunos foram se apropriando da liderança desse espaço. O principal desafio da gestão dos Nureflex foi lidar com uma forte resistência de parte dos alunos, que via no espaço uma "perda de tempo" e que acreditava que aulas seriam de maior utilidade. Ainda, havia alunos que viam certo oportunismo na proposta, como se fosse mais simples e rápido delegar as decisões aos alunos do que tomá-las arbitrariamente.

Aos poucos essa resistência quase geral foi se dissipando e, curiosamente, alguns dos alunos que eram justamente os mais críticos e reticentes sobre o tema tornaram-se também lideranças. Os alunos aproximaram-se da gestão da escola como um todo; as reclamações diminuíram; e, na emergência de problemas, os alunos passaram a tomar atitudes que conduziam diretamente à solução dos problemas.

Após a "apropriação" inicial desse espaço de participação, no entanto, novos desafios emergiram. Uma vez tomados por essa liberdade, muitos alunos passaram a testar seus limites - e vivenciamos episódios de agressividade, violência verbal e discussões fortes que sugerem que a troca respeitosa de ideias é uma prática com a qual os jovens geralmente não têm muita habilidade. Com um público bastante distinto, Korczac se deparava com desafios semelhantes:

Como é difícil a tarefa do educador que chega para iniciar um novo trabalho numa classe (ou num colégio interno) onde as crianças foram até então mantidas num severo rigor e se organizaram, insolentes e traumatizadas, em torno da lei do mais forte, como uma quadrilha de bandidos. Como são fortes e ameaçadoras quando, através de um impulso coletivo, se chocam contra sua própria vontade, como se quisessem derrubar um dique. Não são mais crianças; é um elemento da natureza. (KORCZAC, 1986, p. 80)

Em suma: leva algum tempo para que eles entendam que liberdade para falar não significa que se possa ou deva falar qualquer coisa, sem levar em conta critérios como respeito à diversidade de opções, ideias e pontos de vista.

Por outro lado, uma vez superados esses desafios de "ajuste de liberdade", os 
alunos de fato tomaram a escola para si, o que foi um dos mais marcantes momentos pedagógicos da minha carreira: ver aquele grupo de alunos gerindo aspectos diversos do próprio aprendizado, escolhendo professores, debatendo a constituição dos exercícios coletivos e realizando parcerias com empresas e instituições. Tendo seus vídeos exibidos em festivais diversos e, especialmente, mudando de atitude a "olhos vistos".

Outro aspecto de gestão intensamente revisitado na ELCV foi a administrativa, que durante todo o período da parceria (e desde alguns anos antes) era realizada pela Coordenadora Mônica Cardella, educadora licenciada em Artes Plásticas, com ampla formação em Teatro e experiência no Estado.

Antes da implantação da nova gestão pedagógica, Mônica costumava liderar o processo decisório pedagógico, a um só tempo orientando educadores e desempenhando papéis administrativos fundamentais. Com a minha participação mais direta no âmbito pedagógico, Cardella passou a se dedicar mais intensamente à gestão administrativa da escola - sem deixar de participar de todos os espaços de discussão e construção da pedagogia da escola, especialmente com alunos e professores.

Cardella enfrentava um desafio crônico: os alunos ficavam constantemente irritados e ansiosos com o lento andamento dos processos envolvendo a Prefeitura. Apesar dos seus sensíveis esforços, com os quais na maior parte das vezes conseguia superar dificuldades e burocracias, os alunos não conseguiam compreender os processos que envolviam a Prefeitura.

Um de nossos principais esforços nesse sentido foi implantar uma maior transparência no que diz respeito ao orçamento e formas de acesso a ele dentro das rígidas estruturas da prefeitura. Explicamos aos alunos todos os detalhes: verba da escola, formas de contratação de professores, serviços e sistemas de cotação, licitação e compra de materiais e equipamentos. Cientes dos processos, os alunos passaram a paulatinamente participar e contribuir para que as demandas fossem encaminhadas dentro dos prazos cabíveis. 
Ainda, a transparência administrativa trouxe um segundo benefício, ligado à principal ferramenta democrática implantada na escola: a gestão da grade.

Até o final de 2006, existia um quadro relativamente fixo de educadores, todos atuando em aulas semanais de suas especialidades: roteiro, som, direção, fotografia, produção e história do cinema. Muitos deles já estavam na escola há alguns anos e existia algum histórico de conflito entre alguns deles e alunos da turma em andamento, assim como de turmas anteriores.

Ainda, existia uma visível dificuldade de diálogo entre educadores e alunos, refletida nas avaliações sobre os cursos, constantemente críticas, e que aparentemente não geravam as melhorias esperadas neles.

As primeiras reuniões da pesquisadora com os educadores foram extremamente desgastantes, longas, e evidenciavam um estado de coisas em que uma liderança era tão necessária quanto incômoda.

Ainda, observando os vídeos produzidos pelos alunos, especialmente de turmas anteriores, era possível verificar a presença/influência de alguns tipos muito específicos de cinematografia, e também a ausência especialmente marcante de outras. Grosso modo, se observava uma forte tendência à linguagem ficcional, assim como uma abordagem clássica, tendendo aos filmes de gênero. Uma forte ausência da linguagem documental e também, no próprio âmbito da ficção, de alguma experimentação de linguagem, exploração dos diferentes suportes e diálogo com a produção cinematográfica moderna e pós-moderna - em chave oposta, por exemplo, à cineclubista e à moderna, muito visíveis nos cursos universitários. Observando esse aspecto, comentei em um relatório redigido na época:

Tenho notado com especial frequência que os filmes resultantes das escolas, oficinas e projetos que ensinam vídeo têm, em muito, referências audiovisuais que remetem aos filmes exibidos nas aulas de história do cinema ou sessões que precedem ou ocorrem durante as oficinas. Essa mimese é natural e até desejável, na medida em que é um pouco reproduzindo que se aprende a criar. (RELATÓRIO ELCV, 2007)

Admitindo-se essa hipótese, passamos a ter uma importante questão pela frente, também registrada no relatório: "Que cinema queremos construir na ELCV? É 
uma questão capciosa escolher uma diretriz temática ou estética, porém, negá-la seria não reconhecer a mímese acima descrita. Queremos aqui assessorar a escola do ponto de vista artístico, confiando a ela o desafio de exibir, pesquisar, inquirir, dialogar e contribuir com uma certa, ou certas cinematografias que nos parece oportuno estimular e fomentar”. (RELATÓRIO ELCV, 2007, p. 05)

Nesse sentido, ainda no primeiro semestre de 2007, propus que nas sete semanas de aula disponíveis os alunos travassem contato com educadores com visões bastante distintas sobre os mesmos, como é possível observar também já na proposta escrita em fevereiro:

\begin{abstract}
Ampliação da Equipe pedagógica da ELCV, com a contratação de educadores convidados para ministrarem aulas complementares às especializações, exercícios especiais, atividades e seminários avançados, em aulas regulares esporádicas (durante a semana) e especiais (aos sábados). Inclusão de professores experientes de universidades e também jovens cineastas de fôlego, de São Paulo, ou de outros estados/e estrangeiros de passagem por SP, etc. Oferecer aos alunos diferentes pontos de vista sobre as mesmas áreas de formação, mesmo que conflituosos, dando a eles a oportunidade de optar pelos modelos/exemplos que lhes forem mais adequados. Aumentar o contato dos alunos com artistas jovens e empreendedores. (RELATÓRIO ELCV, 2007, p. 04)
\end{abstract}

Da experiência com educadores convidados - muitos sem qualquer experiência prévia em lecionar, e que foram ou grandes revelações ou alvo de muitas críticas -, tirei uma importante conclusão: os alunos eram, certamente, os melhores analistas do desempenho de um educador. E, caso participassem de sua seleção, seriam, certamente, os melhores supervisores de sua atuação. Eu aventava também a hipótese de que, possivelmente, eles viessem a faltar menos e participar mais, uma vez que estivessem participando de cursos selecionados por eles mesmos.

Assim, na transição do primeiro para o segundo semestre de 2007, foi implantada na ELCV a primeira edição da gestão democrática para seleção de cursos e professores, a partir do envio de propostas de por professores da casa e convidados, e da posterior e livre votação das mesmas pelos alunos.

Como se esperava, houve grande redução nos índices de evasão, e ao final do semestre, apropriando-se das potencialidades da prática, os alunos "demitiram" (ou 
seja, não recontrataram) alguns professores cujo desempenho não agradara, e direcionaram totalmente a seleção dos professores que enviaram as propostas para o primeiro semestre de 2008. Neste processo seletivo, os alunos já pareciam “donos" da proposta, e com um grau de entendimento que permitiu que me auxiliassem a, literalmente, "montar" a grade, o que era um grande desafio nesse momento - quando começamos a diversificar e realizar mais de uma aula por dia, em espaços distintos.

A possibilidade de escolher os cursos não implicava em uma anarquia pedagógica. Sempre participamos, convidando educadores para o processo seletivo, sugerindo nomes e, especialmente, desenvolvendo um ciclo de atividades no qual os eles tinham especial liberdade para se expressar e criar com apoio da escola. Como queria Neill, em Summerhill, onde a frequência às aulas não é obrigatória:

Crianças livres escolhem entre as matérias oferecidas apenas as que lhe interessam. Crianças livres passam a maior parte de seu tempo em outros interesses - carpintaria, metalurgia, pintura, leitura de ficção, representações, jogos e fantasia, audição de discos de jazz". (NEILL, 1966, p. 29)

Outro aspecto que buscamos mudar foi o critério geral de cessão de equipamentos - aliás, como sugeri em todas as entidades em que atuei com semelhante grau de autonomia. Apesar de a escola contar apenas com duas câmeras digitais (sendo apenas uma delas semi-profissional), passamos a permitir o uso das mesmas para projetos não vinculados diretamente ao curso - o que não ocorria com frequência anteriormente.

A parceria com a ELCV se encerrou em janeiro de 2009, quando a segunda turma a ser formada no âmbito da parceria (a primeira cujo processo seletivo havíamos conduzido) entraria em seu segundo semestre. Apesar de, naquele momento, a turma ainda não estar completamente apropriada da gestão da escola, sabe-se que houve grande esforço por parte dos alunos com relação à nova gestão e que, por fim, os encontros do Nureflex foram mantidos e a seleção de professores continuava sendo realizada, em parte, pelos alunos.

Retomando a questão da cessão de equipamentos para projetos pessoais dos alunos: trata-se de um tema cuja relevância vem diminuindo, aos poucos, conforme as entidades da EAP vão renovando seus equipamentos, e os alunos vão encontrando (no 
mundo) um acesso cada vez maior a equipamentos de gravação audiovisual.

Nas entidades, em geral, os equipamentos novos são reservados para as atividades letivas - senão por receio de quebra/roubo, por problemas logísticos para retirada e entrega dos mesmos -, e apenas os antigos são liberados para trabalhos pessoais.

No entanto, algumas entidades criam métodos originais para superar também estes desafios. Quando a AIC adquiriu cinco novas câmeras, havia o objetivo e o desejo de disponibilizar constantemente esses equipamentos, e optou-se por uma gestão coletiva dos mesmos, ao invés da contratação de um profissional para se responsabilizar por eles. Essa decisão é extremamente incomum nas entidades, e demonstra um alto nível de confiança na autonomia de seus alunos.

Ao contrário do que usualmente se percebe no discurso de gestores escolares, da fala de Alexia - que remete ao citado episódio das câmeras - depreende-se uma valorização da atenção, sensibilidade e intuição como elementos essenciais às tomadas de decisão de um gestor: "Não pode ser totalmente intuitivo, mas acho que a gente tem que contar com a intuição também. Então, para eu fazer esse trabalho de gestão de projeto, vai muito de uma sensibilidade. Eu acho que a gente tem que se envolver, para 'sacar' o outro, para observar, para criar procedimentos.” (Informação verbal de Alexia Melo obtida em 2009)

\subsection{2 ... DO ESPAÇO}

"Ele descreveu o seu ideal de aula como sendo a criação de um espaço - isso mesmo! Um espaço! parecido com aquele que existe quando uma criança brinca ao redor da mãe. Explico. A criança pega um botão, leva para a mãe. A mãe ri, e faz um corrupio (você sabe o que é um corrupio?). Pega um pedaço de barbante. Leva para a mãe. A mãe ri e lhe ensina a fazer nós. Ele conclui que o importante não é nem o botão nem o barbante, mas esse espaço lúdico que se ensina sem que se fale sobre ele." (Alves,2001, p. 66) 
"Escola da Ponte: um único espaço, partilhado por todos, sem separação por turmas, sem campainhas anunciando o fim de uma disciplina e o início de outra. A lição social: todos partilhamos de um mesmo mundo. Pequenos e grandes são companheiros numa mesma aventura. Todos se ajudam. Não há competição. Há cooperação. Ao ritmo da vida: os saberes da vida não seguem programas." (Alves, 2001, p. 67)

Na segunda metade do século 18 começa a se definir o espaço escolar como conhecemos: as classes homogêneas e seriadas, alunos enfileirados, testes de desempenho. A disciplina criava espaços complexos, "ao mesmo tempo arquiteturais, funcionais e hierárquicos", garantindo economia de tempo e de gestos, e a obediência dos indivíduos. (FOUCAULT, 2008, p. 126)

Rubem Alves vem observando na prática as implicações disciplinares dos usos clássicos do espaço no cotidiano escolar:

Nas escolas: salas separadas (o que se ensina é que a vida é cheia de espaços estanques); turmas separadas e hierarquizadas (o que se ensina é que a vida é feita de grupos sociais separados, uns em cima dos outros). Consequência prática: a competição entre as turmas, competição que chega à violência (os trotes!). Saberes ministrados em tempos definidos, um após o outro: o que se ensina é que os saberes são compartimentos estanques (e depois reclamam que os alunos não conseguem integrar o conhecimento). Apelam então para a "transdisciplinaridade", para corrigir o estrago feito. (ALVES, 2001, p. 67)

Segundo Foucault, trata-se da "arte das distribuições" dos indivíduos no espaço - na qual prevalece o "princípio do quadriculamento" -, que visa:

[...] estabelecer as presenças e as ausências, saber onde e como encontrar os indivíduos, instaurar as comunicações úteis, interromper as outras, poder a cada instante vigiar o comportamento de cada um, apreciá-lo, sancioná-lo, medir as qualidades ou os méritos. Procedimento, portanto, para conhecer, dominar e utilizar. A disciplina organiza um espaço analítico. (FOUCAULT, 2008, p. 123)

Mas como são os espaços em que ocorrem os processos educativos das entidades pesquisadas?

Inicialmente, há que se levar em conta as instâncias em que ocorrem tais 
atividades. Ao contrário dos Vídeos Populares produzidos no "chão de fábrica" e no território dos movimentos sociais, os ambientes típicos de desenvolvimento da Educação Audiovisual Popular e do Cinema de Quebrada, nos últimos dez anos, têm sido as associações e organizações da sociedade civil sem fins lucrativos (ONGs, OSCIPs e afins). Nesse âmbito, com raras exceções ${ }^{50}$, as entidades desenvolvem atividades em espaços adaptados para os processos educativos: prédios ou casas alugadas, salas emprestadas de escolas e entidades públicas, etc.

Nesses espaços, as salas de aula, como se pode imaginar, estão praticamente onipresentes. No entanto, registram-se as mais diversas formas de uso: a "clássicamagistral" (o professor em frente à lousa e os alunos enfileirados); rodas ou círculos de conversa, formados por cadeiras ou pelos alunos sentados no chão (espaço da participação); participativo-performático (alunos "em cena" participam ativamente da ocupação deste espaço); cinematográfico (simulando o espaço do set cinematográfico); profissional-coletivo; etc.

Mas, o uso das "rodas de conversa", tanto para debates como para aulas característico das atividades do terceiro setor é o mais difundido entre educadores.

Em muitas entidades, as salas de aula integram-se naturalmente ao espaço de circulação da própria entidade, de modo que as atividades ocorrem quase em um processo contínuo de convivência entre alunos e equipe, que excede o tempo oficial das aulas.

Após anos localizados em uma sede "incubada" por outra entidade, em Botafogo, o Cinema Nosso agora possui sede própria: um prédio de três andares, localizado na Lapa, e que foi doado por Fernando Meirelles, em sistema de comodato, para o grupo. A chegada a esse novo espaço foi uma grande conquista, permitindo a construção de uma sala de projeção, de acesso público, além de salas de aula, ilhas de edição e administração. E a perspectiva criada pelos novos espaços fez com que a equipe se deparasse com novos desafios, especialmente no que tange ao acesso e apropriação do espaço pelos alunos, como comenta Miriam Machado:

\footnotetext{
${ }^{50}$ Por exemplo: O prédio do Instituto Criar foi desenvolvido por Sílvio Oksman e Fernanda Neiva, fazendo uso de parte das instalações de uma fábrica que existia no local.
} 
Eu sou a coordenadora do sócio-pedagógico; tem a assistente, e a secretária, que fica em contato diário com os alunos. O pessoal da administração não tem esse contato, então, o que fazer? Porque era um problema que não tínhamos há muito pouco tempo atrás, agora estamos "num bloco em cima do outro"; antes estávamos um dentro do outro, não tinha espaço, tínhamos que dividi-lo. São coisas simples, mas é preciso pensar em formas, porque não estamos querendo replicar a escola formal [.... Ter a sala de cinema, conseguir ter os espaços, ainda é algo novo. E isso acaba nos impondo uma forma de ser também. "O fulano pode entrar e usar o que ele quer na hora que ele quer"? Faz diferença em "ser assim". Então: "ninguém entra, só no horário da aula"; e assim, existe uma outra forma de ser, de pensar educação e de pensar cinema. Por isso que eu digo que essa construção existe permanentemente, mas hoje ela é muito forte. [...] Talvez no final de 2009 tenhamos mais algumas certezas, mas, enfim, virão outras dúvidas...[....](Informação verbal de Miriam Machado, 2009)

O espaço do Cinema Nosso é vertical: no térreo há a sala de cinema, na qual ocorrem exibições e mostras, em diversas parcerias nacionais e internacionais; no primeiro andar há uma grande sala de aula; no segundo andar há a ilha de edição, onde ficam também os equipamentos, a sala da produtora social, onde os ex-alunos atuam profissionalmente, e a biblioteca. Entre o terceiro e o quarto andar, há um espaço intermediário onde ficam disponíveis computadores para acesso à internet. E no quarto andar, ficam as salas de aula de animação e a sala de administração da entidade.

Na AIC, no Favela é isso aí e na Oficina de Imagens, em Belo Horizonte, e no Instituto Criar, em São Paulo, percebemos uma configuração espacial semelhante, no que diz respeito à distribuição dos espaços de trabalho: salas de aula, salas administrativas, de trabalho da equipe de coordenadores e educadores, de uso coletivo, ilhas de edição/equipamentos e, em algumas delas, salas de convivência voltadas para os alunos e ex-alunos.

Característica bastante comum nesses espaços, possivelmente por contarem com a presença e fluxo constante de alunos, é a informalidade: murais com títulos divertidos, bilhetes, sistemas criativos de comunicação. Como a metodologia Kraftwerk da AIC: um glossário desenvolvido coletivamente em um longo papel Craft colado na parede: "a gente gosta muito de criar um glossário, então eu falo uma palavra, você não entende, então: ‘o que vocês acham que é essa palavra?'. E aí vai, escrevendo num Kraft; chamamos de metodologia Kraftverk, que é colar kraft na parede e ficar riscando tudo no kraft, sabe?" (Informação verbal de Alexia Melo, 2009) 
Mas, como vimos, os espaços físicos das ONGs/OSCIPs nem sempre são os locais onde de fato ocorrem os processos formativos. Projetos semi-itinerantes realizam parte de suas atividades em suas sedes, e parte em comunidades diversas em geral, do interior dos estados onde estão localizados -, em modelo itinerante, como é o caso do Cinema Nosso ${ }^{51}$, da Oficina de Imagens ${ }^{52}$ e da $\mathrm{AIC}^{53}$, dentre muitos outros.

Há uma entidade que leva o conceito de "espaço educativo" a um paroxismo: O Projeto Morrinho, do Rio de Janeiro, o faz a partir de um processo muito particular de construção de sua maquete-obra de arte- espaço de aprendizagem coletiva.

O projeto se tornou conhecido no país, com divulgação em diversos canais de televisão e revistas, depois que a experiência foi levada para a Bienal de Veneza, em 2007.

Mas o que exatamente é o Morrinho? Mais fácil começar pelo que ele não é: $\mathrm{O}$ Morrinho não é uma escola, não tem atividades regulares de formação, não é apenas uma OSCIP ou produtora de vídeo, e os jovens que nele atuam não são professores, tampouco alunos.

Seria impossível dizer, também, que o Morrinho seja apenas um ou outro. $\mathrm{O}$ Morrinho é uma obra de arte a céu aberto, um espaço de socialização e troca cultural, um espaço de produção audiovisual, e um local de visitação turística.

O Morrinho foi criado pelos irmãos Nelcirlan e Maicon Souza de Oliveira (o cantor "Mc Maiquinho"), no quintal da casa em que moravam, na comunidade Pereira Leite - no sopé do Morro Santa Tereza, onde fica o bairro boêmio homônimo.

\footnotetext{
${ }^{51}$ O Cinema Nosso oferece cursos regulares, em sua sede, e também realiza diversas atividades em espaços externos: de "dias de vivência audiovisual" realizados em escolas públicas da região central do Rio de Janeiro a oficinas de interpretação e produção, realizadas em comunidades de países africanos como Cabo Verde e Senegal.

${ }^{52}$ A Oficina de Imagens realiza diversos projetos simultaneamente: oficinas voltadas a estudantes de escolas públicas da grande Belo Horizonte, intervenções audiovisuais que estimulam a implantação de núcleos audiovisuais (Projeto Ocupar Espaços) em comunidades diversas do interior do estado de Minas Gerais e outras atividades na própria sede da entidade.

${ }^{53}$ A Associação Imagem Comunitária (AIC) também realiza projetos simultâneos em sua sede e no interior de Minas Gerais: de processos de formação e expressão para a comunicação (Rede Jovem de Cidadania) realizados na própria OSCIP a atividades de formação de lideranças (Juventude de Atitude), em comunidades do Vale do Jequitinhonha e de outras regiões do estado.
} 
Tratava-se, inicialmente, de uma brincadeira: uma maquete, produzida com tijolos quebrados, e que reproduzia, em miniatura, a estética do próprio morro em que moravam. Como comenta o produtor Chico Serra, produtor do projeto:

\begin{abstract}
Era, era uma área grande, que foi aumentando. Aí eles foram mudando várias coisas [...], na verdade, o primeiro Morrinho mesmo era com azulejo: o pai de um garoto era um pedreiro conhecido lá do morro, já tinha feito várias casas, e tinha um material de construção no quintal... o garoto pegou um azulejo ali e botou a casinha, e virou um barraquinho. Aí descobriram que com tijolo era mais estável [...] eles montavam a casinha, pegando uns tijolos, aí quebravam o tijolo, dividiam em dois, faziam a janelinha, até virar um barraco... foi a "sacada" genial da "galera". Então eles me contaram que no começo os bonecos eram de chapinha de refrigerante, aquela tampinha de garrafa PET. Aí foi evoluindo... O carrinho de miniatura era o que eles conseguiam. Agora já tem um pouco com mais critério: "não, tem que ser com carrinho, tem uma escala certa, assim, se você chegar com o carrinho um pouquinho maior ou um pouquinho menor, não pode, assim, não entra no morro. (Informação verbal de Francisco Serra,2009)
\end{abstract}

A maquete foi crescendo e outras crianças passaram a participar da brincadeira, para as quais regras de convivência foram desenvolvidas pelas crianças e adolescentes.

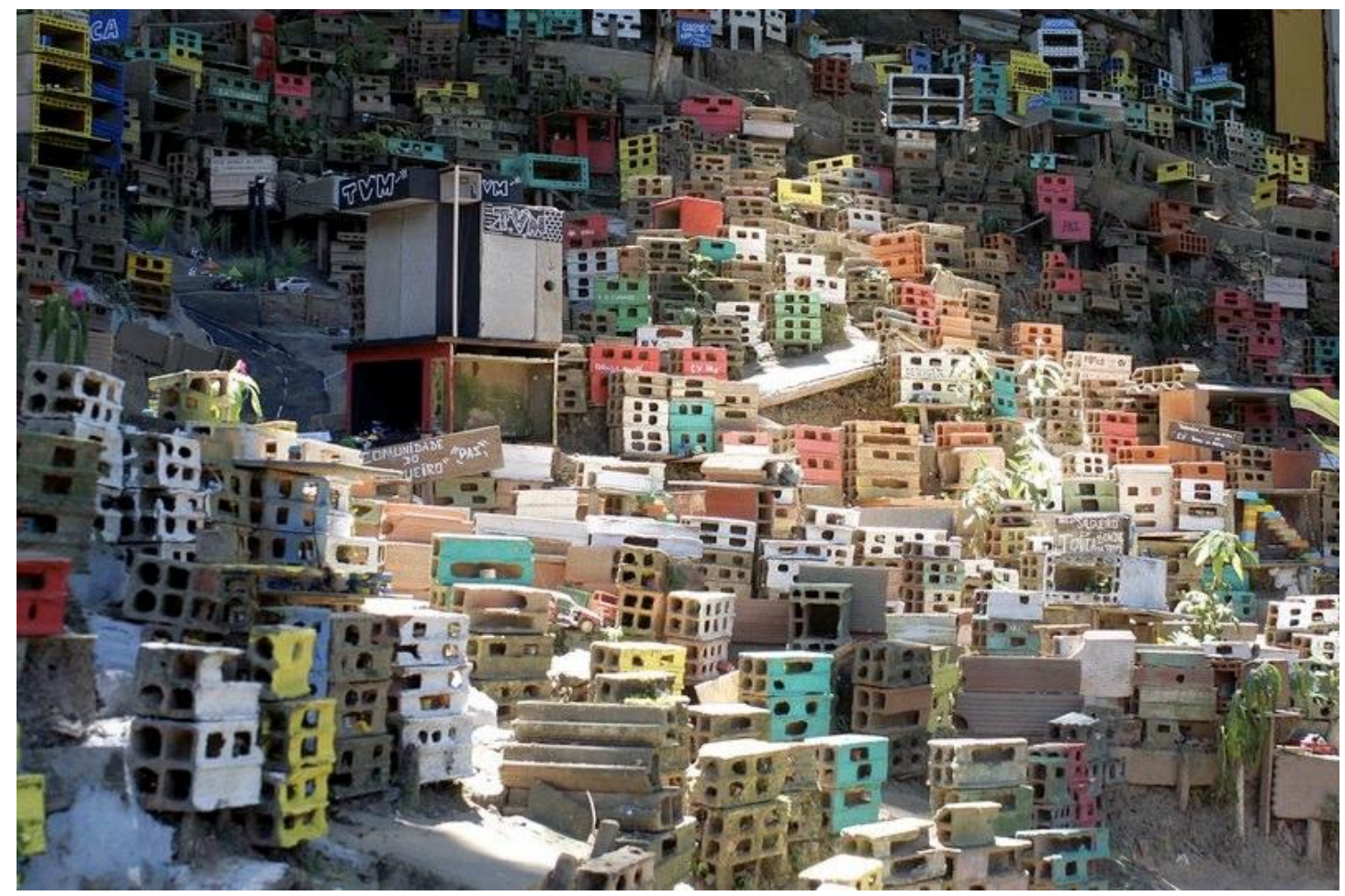

Figura 1 - Maquete do Projeto Morrinho

A maquete é habitada por personagens da maquete são feitos com peças ou 
bonecos do tipo Lego. As crianças e adolescentes personalizam, criam "figurinos" e caracterizam seus bonecos de acordo com o papel que cada boneco tem no sistema social do Morrinho.

Cada um possui o "seu Morro", ou vários morros, que até mesmo visualmente buscam reproduzir a política dos morros existentes no Rio de Janeiro. Morros que na vida real são dominados por determinadas facções, são visualmente atribuídos a estas que também estão nas maquetes, e dentre os "morrinhos" há relações pautadas pelas "relações de morros" da vida real. Dentre os personagens que cada criança ou adolescente controla, há toda a hierarquia típica do tráfico: gerentes, aviões, playboys que sobem o morro, assim como familiares e vizinhos, com seus pequenos negócios, além de policiais e paramédicos.

Parece simples, mas não é. Cada criança controla mais de um boneco, mas isso não significa que eles tenham "vida eterna" ou possam fazer "o que quiserem". O morrinho é um micro-mundo, que respeita diversas regras e leis físicas do mundo real - por exemplo, em um aviso disposto em meio à maquete, se lê: “carro não voa!"

\footnotetext{
Não pode voar com o boneco, não pode matar boneco sem ser na mira. Exemplo: se você cai do primeiro andar, você morre! Tem várias regras. Não pode roubar! Tem que ser alguém responsável, que brinca com os bonecos. "Gringo e playboy podem brincar no Morrinho também?" Pode. Mas, por exemplo, se sai do Morrinho, não pode mais voltar mais! (Informação verbal de Serra, 2009)
}

Como na vida real, muitas vezes há tentativas de "invasão" de um morrinho a outro. Nesses casos, os bonecos utilizam armas improvisadas dos mais diversos modelos - muitas vezes emprestadas de outras linhas de brinquedos! - e obrigatoriamente devem mirar e atirar fazendo ruídos sonoros que reproduzam as armas que disparam. Personagens alvejados podem ser socorridos por ambulâncias e levados para o hospital. E, muitas vezes, morrem, o que obriga seus donos a necessariamente desmontar o boneco - simbolizando sua morte.

Eles atribuem vozes aos personagens, caricatas e, em geral, mais agudas que as vozes naturais, fazendo com que seja bastante visível quando eles estão "brincando" e quando estão discutindo com suas vozes normais. 
Durante a visita, realizada em março de 2009, assistimos a um forte debate entre dois jovens sobre a mira de um deles durante um tiroteio; um deles afirmara que o tiro fora preciso. E o outro alegava que a arma estava sem mira, e que o tiro "passou longe". Na tarde que passamos no Morrinho, além dos dois jovens, cerca de cinco crianças brincavam em seus "pedaços de Morrinho". Uma delas estava organizando e divulgando entre elas um baile funk que seria promovido na quadra de uma escola, no "Morrinho da Coreia" - visualmente similar ao original. As crianças estavam, justamente, buscando conseguir caixas de som de computadores emprestadas para sonorizar a festa em miniatura.

Em 2001, o cineasta Fábio Gavião conheceu Cirlan e os outros oito meninos que construíram e brincavam no Morrinho com ele, até então: José Carlos Silva Pereira "Júnior", Luciano de Almeida, Marcus Vinícius Ferreira, Maycon Souza de Oliveira "MC Maiquinho", Paulo Vítor da Silva Dias, Raniere Dias, Renato Dias, Rodrigo de Maceda Perpétuo.

Juntaram-se-se a Gavião os produtores Markão Oliveira e Chico Serra e em 2005 foi fundada a OSCIP Projeto Morrinho. A partir desse encontro entre "jovens do asfalto" e do Morrinho, começa uma prolífica videografia, protagonizada por personagens que habitam a maquete.

Desde então, os roteiros e vídeo foram desenvolvidos a partir de diferentes modelos: improvisações realizadas pelas crianças e jovens, sobre temas de interesse próprio; vídeos encomendados para o canal infantil Nickelodeon, que exigiram um esforço para criar roteiros "politicamente corretos" e adequados a esse público; e roteiros para uma espécie de "live show", uma "encenação ao vivo" transmitida por microcâmeras em evento especial realizado em 2008 em Viena, na Áustria, e em Berlim, na Alemanha.

Em 2008 foi lançado o documentário "Morrinho: Deus sabe tudo mas não é X9”, fruto de sete anos de parceria entre Gavião, os irmãos Oliveira e os demais jovens do Morrinho. 
Além das produções audiovisuais, que vem obtendo grande destaque nos festivais por onde passam, o Projeto Morrinho realiza atividades que enfocam o aspecto mais visual da experiência. A Bienal de Veneza levou o grupo de jovens, em 2007, para reconstruir um Morrinho em suas dependências. Como está descrito no site do projeto, o Morrinho já ganhou o mundo:

\begin{abstract}
Nos últimos anos, o grupo exibiu maquetes de escala menor do que a maquete do Morrinho no Brasil e na Europa, incluindo o Fórum Urbano do Mundo em Barcelona (2004), O Ponto Ephémère em Paris (2005), e a Bienal de Veneza (2007). O caráter e a inovação original das maquetes de Morrinho foram reconhecidos por críticos como uma expressão legítima da arte contemporânea, e continuam a chamar a atenção internacional de jornalistas, arquitetos, músicos, acadêmicos e turistas. ${ }^{54}$
\end{abstract}

O grupo já realizou oficinas visando a produção de maquete semelhante em unidades da rede SESC da capital paulista. Todos os finais de semana há grupos guiados de turismo que visitam a maquete, gerando renda com ingressos e venda de vídeos e pequenos subprodutos, como tijolos pintados que remetem aos barracos das maquetes. E o site do projeto possui um mecanismo que permite doações, que ocorrem com bastante frequência - especialmente por estrangeiros.

O Morrinho não é uma escola. Os mais jovens aprendem com os mais velhos, assistindo e participando. Os cineastas que estimularam a formalização e promoveram a implantação do audiovisual como linguagem não se colocam como educadores. Gavião, desde que os encontrou, começou a produzir o documentário - que somente recentemente foi lançado. O lento processo de produção do filme promoveu naturalmente a "sedução" da ferramenta audiovisual, hoje totalmente incorporada ao cotidiano do projeto.

Mas a polêmica é inevitável: seria educativo manter crianças e jovens "brincando de bandido"? Seria saudável reconstruir em miniatura um espaço social de aprendizagem e brincadeira em que se reproduzem todos os conflitos vividos "na vida real"?

Vamos aos fatos: a comunidade Pereira Leite é uma espécie de Oásis. Situada ao lado de uma base de formação do Bope, atualmente não possui tráfico de drogas

\footnotetext{
${ }^{54}$ Site www.tvmorrinho.com, acessado em 25 de maio de 2009
} 
aparente nem é controlada por facções ou milícias. Nesse contexto, a brincadeira é realmente hipotética, envolve a temática do crime - cotidiano conhecido por todos, mas em um processo que desenvolve a auto-estima e entretém. Como comenta Nelcirlan Souza de Oliveira:

Hoje em dia, ao invés de eu dar uma arma, eu posso dar um espaço pra ele: dou um morro! É tipo assim: no Morrinho você tem gerente, e no tráfico você também tem gerente... no Morrinho você tem o braço direito, no tráfico você também tem o braço direito... é tipo um tráfico da paz; no Morrinho é uma coisa diferente: você trafica cultura, trafica arte. A droga é o tijolo. Ele vicia... toda hora você quer quebrar um, é uma droga diferente! Acho que é até uma droga mais gostosa de saborear! (informação verbal de Nelcirlan Souza de Oliveira obtida em 14 de março de 2009)

Não há, como alguns poderiam esperar, uma escalada - da brincadeira à vida real -, com uma exceção que foi bastante sentida pelo grupo, de um jovem que nunca se distanciara do tráfico. O que ocorre normalmente é o movimento oposto: jovens que, depois de experiências iniciais com o tráfico, buscam no Morrinho um tempoespaço para si mesmos.

De vez em quando, aparece, eles querem que eu leve eles pro baile... daí, tem que pedir pra mãe, e lá vou eu e peço: "deixa ir comigo, vou tomar conta". E falo: "mas eu sou meio maluco (risos), eu vou pra 'zoar', vou pra 'curtir' o baile”. E ela: “mas toma conta dele; se está do seu lado, eu sei que está bem...” E eu: "não! Vai voltar bem, está na idade já que eles estão começando a sair...Vai 'curtir', vai ficar legal. Acho que "rola" sim, de vez em quando ser meio pai, meio tio... isso é legal...(informação verbal de Nelcirlan Souza de Oliveira)

\subsection{3 ... DA ADESÃO}

"O assunto que mais entusiasmo desperta é a comida. Mais de uma vez dei vida a uma reunião insípida propondo que fosse abolido o hábito de repetir a comida."

(NEILL, 1966, p. 43)

Três elementos centrais compõem a estratégia mais comumente utilizada pelas entidades da EAP para facilitar a frequência e promover a adesão dos alunos ao processo educativo: alimentação, auxílio transporte e bolsa de estudos. 
A questão da alimentação é uma preocupação constante ao mesmo tempo em que se constitui também em grande desafio. Os entrevistados foram quase unânimes em afirmar a importância em se oferecer alimentação aos alunos; mas muitos projetos simplesmente não conseguem fazê-lo por falta de recursos e estrutura adequada. E outros também não o fazem por receio que a alimentação oferecida seja, por fim, a maior motivação, trazendo para o grupo pessoas desinteressadas pelo tema em si.

Em entidades nas quais os alunos permanecem por longos períodos de tempo, sempre se busca oferecer refeições completas. Os maiores desafios a esse desejo são necessidade de construção de cozinhas com porte adequado à dimensão da entidade e contratação de pessoal especializado, entre outros.

A Casa do Zezinho possui um cuidado extremo com a questão da alimentação. Em todos os períodos se oferece alimentação saudável, completa e de qualidade. Em uma das histórias relatadas por Tia Dag no livro A pedagogia do cuidado, comenta-se que um aluno se acalmou entre uma "xícara de chá e um pedaço de bolo" (ANTUNES; GARROUX, 2008a, p. 72) imagem fácil de visualizar para quem já visitou a entidade, onde se sente constantemente os aromas da padaria e de uma cozinha industrial que serve deliciosos lanches e almoços para todos.

É difícil, no cotidiano das entidades, priorizar a destinação de recursos para a alimentação dos alunos. No estado atual de coisas, a maior parte das entidades vive no limite entre ter o suficiente para pagar os salários e as contas, sendo realmente raros os casos em que é possível oferecer aos educandos alimentação de efetiva qualidade como em geral todos gostariam de fazer.

No entanto, é senso comum nas entidades a necessidade imperativa de se oferecer ao menos um lanche simples durante a realização de atividades audiovisuais, que exigem muita concentração e energia. Como comenta Hélio Passos, coordenador do Projeto BH Cidadania:

Eu fui uma das pessoas que "bateu o pé" nisso lá, que discutiu com os coordenadores do projeto BH Cidadania essa questão de ter um lanche para os meninos. [...] Eu acho que toda criança tem fome, e não só porque é carente; a de classe alta, se ficar 3 horas, 4 horas 
trabalhando junto, não vai, num intervalo de 2 horas querer se alimentar? É discutível se você tem que dar, se tem que ser paternalista, mas eu acho que é fundamental [...] porque a alimentação também sociabiliza. (Informação verbal de Hélio Passos, 2009)

Em entidades cujos projetos concentram as atividades em uma ou duas semanas, ou em três ou quatro finais de semana de aula, nas quais em geral as atividades ocorrem o dia todo (nos finais de semana e férias escolares), ou em longos períodos, é comum que ofereçam refeições completas, além de lanches e, como veremos, também ajuda de custo e/ou vale transporte.

No entanto, em projetos de orçamento reduzido, muitas vezes a necessidade que se impõe exige que as equipes improvisem:

\begin{abstract}
Alimentação... a gente faz um lanche à tarde, mas uma coisa que acontece [...] é que a alimentação puxa transporte... Por exemplo: no começo, a gente não tinha orçado a alimentação no período de edição, e até hoje, não é oficialmente uma coisa que ocorre na prática. A gente acaba pegando a nossa verba de alimentação e comendo todo mundo junto; pedimos uma pizza. [...] No momento em que a gente está com eles, está todo mundo junto, então não tem cabimento comer sozinho... foi uma postura que a gente adotou [...], o orçamento é fechado no começo do ano, então, nas outras oficinas que a gente fez depois, a gente orçou almoço no período de edição. Foi uma coisa que a gente não tinha previsto inicialmente; a gente já tinha vendido, não tinha essa rubrica, a gente adaptou...(Informação verbal de Igor Barradas, 2009)
\end{abstract}

Algumas entidades possuem verba ou parcerias para oferecimento sistemático de alimentação, como por exemplo, o Instituto Criar, que desde sua formação realizava uma parceria com uma empresa. Ainda que todos fossem gratos pela parceria, o caráter semi-pronto do alimento era profundamente criticado por ex-alunos e educadores. Fiabane comenta que foi apenas depois da contratação da Nutri e Viva, OSCIP que passou a ser responsável pelo acompanhamento nutricional dos alunos, a contratação de um jovem chef e a finalização dos pratos na cozinha do Instituto, que tais desafios foram superados. Segundo Fiabane, foi inicialmente um choque para os alunos:

A alimentação coletiva, que é o termo ainda, é uma questão que você não consegue superar quando você vai trabalhar com 150 pessoas; mas a questão é que a comida vinha praticamente pronta, e isso piora muito a qualidade dela, tanto em aspectos estéticos quanto aspectos nutricionais e tudo o mais. Fora isso, a gente também não tinha muito controle sobre o que era oferecido. Quando a gente encerrou a parceria, na verdade teve uma parceria com a Sodex Ho. A gente já melhorou: a comida começou a ser finalizada aqui. Mas a gente não estava muito preocupada ainda com o cardápio, porque não tinha muito espaço para isso. Quando terminou, e a gente foi repensar, eu conversei com a diretoria: "olha, já que a gente vai repensar, eu queria repensar bacana". Veio uma ideia de uma nova parceria que surgiu do relacionamento 
deles, e foi muito feliz, porque o dono da empresa mandou uma pessoa para conversar com a gente, era uma pessoa muito sensível [...] A gente fez com que o espaço da alimentação do Instituto virasse um laboratório de alimentação saudável mesmo. Então mudou um pouco o perfil da equipe: a gente passou a contar com um chef de cozinha. Ele consegue trabalhar com um universo de ingredientes muito mais amplo, e com um cardápio muito mais atrativo, usando muito mais tempero do que sal. Enfim, a nutricionista vem do Instituto Nutri Viva, que é uma organização voltada para isso também. Então, tem muita informação, tem muita pesquisa, tem um site. Eles fazem a avaliação nutricional de cada aluno, dão um feedback para eles. Tem todo um processo de comunicação interna dentro do restaurante que vai dando dicas de alimentação para eles também. De vez em quando passa uma cumbuquinha com alguma coisa diferente para, aos pouquinhos, ir mudando o paladar; não tem mais suco, hoje em dia tem chá ou água aromatizada. Está sendo bem bacana. Com a primeira turma foi mais difícil, eles saíam para comprar guaraná Dolly, e a gente ficava "aí". Mas, com essa turma que chegou e já encontrou essa situação, foi super bem aceita. [...](Informação verbal de Danelle Fiabane obtida em 22 de setembro de 2009)

É importante destacar que o IC possui uma característica bastante singular: compõe seu grupo de alunos a partir de egressos de outros projetos sociais. Essa característica, nos primeiros anos, fazia com que parte dos alunos não se apropriasse do IC. Literalmente, muitos alunos recusavam-se a "vestir as camisas" do IC (que recebiam ao entrar no curso), com as quais teoricamente deveriam frequentá-lo. Danielle Fiabane comenta que o aprimoramento da alimentação faz parte de um conjunto de estratégias para superar esse desafio:

A comida tem uma importância para a cultura, para as relações que se estabelecem em um grupo e aqui. Lembra que eu te falava: "Poxa, mas eles usam a camiseta da outra ONG; o vínculo que eles têm com a outra ONG, eles não têm com o IC!” E eu acho que faz parte na formação de vínculo se dar um pouco de atenção para todas as necessidades que o jovem tem, dentre elas, a alimentação. (Informação verbal de Danelle Fiabane obtida em 22 de setembro de 2009)

Em entidades que, a despeito desse desejo, não têm condições de oferecer tais condições, são desenvolvidas estratégias criativas, tais como sugerir lanches coletivos (cada aluno traz algo a ser preparado na cozinha não industrial da entidade), a preparação de comidas simples, e a realização de parcerias com restaurantes da região para obtenção de descontos.

Melo comentou sobre a dificuldade de se obter recursos para essa rubrica do orçamento. Para minimizar o impacto negativo, busca-se na AIC sempre oferecer um lanche, ainda que simples, ou ao menos organizar a realização de um jantar coletivo, na própria cozinha da entidade: 
Da alimentação? Também acho que anda junto com a questão do transporte. E ter um lanche bacana, para espairecer, trocar ideia, o famoso coffe break (risos), que é quando as pessoas também se encontram e conversam. Mas a gente tenta ver o que a gente pode, se falta alguma coisa [...]. É uma prioridade, mas pode ser pão com manteiga, pelo menos. Não vai ter o canapé, mas o pão com manteiga, ou um biscoito. E é igual o transporte, mas o transporte é mais prioritário que o lanche. O lanche é caro. Tem gente que vem aqui, que trabalha de noite e vira a noite para vir aqui, e aí "dá um cochilo" antes de minutar. Então nós fazemos alguns almoços coletivos [...], cada dia trás uma fruta. Vai meio que um vai ajudando o outro, porque senão, "saco vazio não para não" (risos) o negócio é... (Informação verbal de Alexia Melo, 2009)

Vinícius Azevedo, da CUFA, destaca a importância da alimentação, e como Melo, ressalta ainda o papel central do auxílio-transporte, não apenas para que os jovens frequentem as oficinas, mas para que possam circular para além de seus bairros de origem:

Ter lanche foi fundamental para os alunos; mas ter transporte torna tudo muito melhor. Os alunos que moram longe querem participar, e têm dificuldade de se integrar com o resto da cidade. Os alunos, na maioria, nem conhecem o centro do Rio de Janeiro. Às vezes, nunca foram, e muito menos à Zona Sul.

Para jovens que ainda estão fora do mundo do trabalho, o valor das passagens representa uma fatia considerável do orçamento familiar, tornando-se de fato elemento decisivo para manter a frequência deles às aulas. Como comenta de forma bem-humorada Josinaldo Medeiros, educador das Oficinas Humano-Mar, promovidas pela Abaeté, e ex-aluno das Oficinas Cinemaneiro e presidente da Cidadela $^{55}$ :

Nas edições do Cinemaneiro, a "galera" trabalhava... Era monitor de turma, fazia making of para gerar uma renda, pelo menos para pagar a passagem. Porque uma das maiores dificuldades que a gente tinha era se deslocar para o centro. É dinheiro para transporte. Muitas vezes, eu e meu amigo Ícaro vínhamos de bicicleta, pela Avenida Brasil, Linha Amarela. Vinha e ia embora de bike, porque a gente não tinha dinheiro. Sempre pedíamos a um comerciante, o S. Hélio, e ele dizia: "que cinema o quê, rapaz!" (Informação verbal de Josinaldo Medeiros, 2009)

Especialmente quando as entidades se localizam no centro, ou no caso das Oficinas Itinerantes - que costumam atrair jovens de cidades próximas aos locais visitados -, o auxílio-transporte é considerado pré-requisito fundamental. Projetos como as Oficinas Kinoforum e as Oficinas Tela Brasil, por exemplo, oferecem auxílio nesse sentido.

Idealizei o projeto pedagógico inicial das Oficinas Tela Brasil também como

\footnotetext{
${ }^{55}$ Oscip fundada por ex-alunos das Oficinas Cinemaneiro (promovidas por Boteco Cinematográfico e Fora do Eixo Filmes).
} 
projeto-piloto e já no âmbito da elaboração desta tese, no início de 2007. Como no caso da ELCV, idealizei e implantei, nessa experiência, aspectos pedagógicos e de gestão bastante específicos, cuja abrangência foi limitada pela necessidade de cumprir com os objetivos mais amplos do projeto, da coordenação geral e do perfil de financiamento (privado). De todo modo, no âmbito da alimentação, por exemplo, foi possível implantar um modelo de gestão exatamente como se gostaria: no estabelecimento das parcerias com as entidades locais temos como prerrogativa a presença de cozinha industrial ou com equipamentos que permitam cozinhar no próprio espaço. Contratamos um cozinheiro local de competência reconhecida, e oferecemos um rico cardápio, com café da manhã, almoço e lanche da tarde, no qual alunos e equipes alimentam-se juntos, em intensa troca social.

Para Aléxia Melo, da AIC, a alimentação muitas vezes pode até ser improvisada coletivamente, mas a existência de recursos para o "vale-transporte" é o elemento mais decisivo para a realização de atividades - como o Conselho de Jovens, encontro participativo realizado sistematicamente e que envolve dezenas de jovens de toda a cidade de Belo Horizonte:

\begin{abstract}
Ano passado, infelizmente, a gente não conseguiu fazer nenhuma reunião do Conselho, porque ele estava atrelado ao projeto Jovem Cidadania. Atrelado no sentido de recursos, que é quando a gente chama oitenta jovens para vir aqui, a gente dá vale-transporte para todos e lanche, porque senão não existe Conselho. Inclusive, todas as atividades que a gente faz aqui o transporte inclusive é uma discussão política, que a gente faz aqui dentro - se não fornecemos o vale, não funciona. [...] É, pode não ser "O rango", mas tem pão e café. Mas o transporte é o que mais conta, para que se possa transitar, né? [...] (Informação verbal de Alexia Melo, 2009)
\end{abstract}

Algumas entidades conseguem estabelecer parcerias ou captar patrocínios para oferecer também auxílios em dinheiro - bolsas de estudo voltadas a um suporte mais amplo à frequência plena do aluno no curso. Dois casos de São Paulo ilustram essa modalidade.

O Instituto Criar oferece uma bolsa mensal de um salário mínimo, além dos já citados auxílio-transporte e alimentação completa. As bolsas são financiadas através de parceria com as prefeituras de São Paulo e Osasco, através do programa Bolsa Trabalho. A bolsa, nesse caso, tem o objetivo de oferecer suporte para que os alunos 
não tenham a necessidade de trabalhar durante a formação.

As Oficinas Itinerantes de Vídeo Tela Brasil oferecem, além de alimentação completa, uma bolsa de aproximadamente $\mathrm{R} \$ 100,00$ para dar suporte à pesquisa e preparação do aluno durante o processo da oficina, que dura cerca de 15 dias (praticamente ininterruptos).

\subsection{4 ... DA INTERAÇÃO}

"A diferença é nosso ponto de encontro. Imagine duas tribos nas duas margens de um rio. Cada tribo pode viver por si mesma, falar da outra, falar mal ou elogiá-la. Porém, cada vez que cruza o rio e vai à outra margem, o faz para trocar algo. Não cruza a água para ensinar, falar, se divertir, mas para dar e receber: um punhado de sal por um pedaço de tecido, um arco por algumas pérolas. Trocamos nosso patrimônio cultural.

(BARBA, 1993. p. 106)

Neste Subcapítulo, foram utilizados dados captados através de todos os instrumentos criados para a pesquisa e elementos que vêm da minha experiência pessoal - sobretudo no estabelecimento de sínteses.

Dentre as pedagogicidades da EAP, talvez a que mais se diferencie dos campos correlatos da educação não formal seja a pedagogicidade da interação entre os alunos e a equipe educativa - em geral, composta por um ou mais educadores e coordenadores.

Os profissionais que atuam na EAP o fazem com uma liberdade criativa e pedagógica tal que algumas respostas dadas nas entrevistas foram suprimidas deste documento, em comum acordo com eles, de modo a evitar um excesso de exposição de suas práticas radicais que possa vir a comprometer o andamento das mesmas.

A riqueza do seu universo de atuação chegou a me colocar em dúvida sobre o próprio objetivo desta tese; se não seria o caso de focar esta pesquisa especificamente 
na atuação de seus profissionais e suas inestimáveis contribuições. No entanto, dada a inexistência de uma pesquisa prévia de fôlego sobre as características pedagógicas da EAP em uma abordagem mais ampla, acabei desistindo da ideia. Não obstante, fica aqui o alerta de que esse tema sugere muito mais dedicação e espaço, dando conta certamente de ser objeto único, por exemplo, de outra tese de doutorado.

Algumas características gerais se destacam inicialmente, com seus desafios e implicações:

a) origens e níveis de conhecimento sobre campos correlatos da educação. Há, dentre os coordenadores e educadores, profissionais com formação em áreas próximas do audiovisual, como Cinema, Audiovisual, Rádio e TV, Comunicação, Publicidade; da educação, como Pedagogia, e licenciaturas variadas; das Ciências Humanas, como Assistência Social, Psicologia, História, Geografia, Filosofia, Arquitetura, Administração; e também profissionais sem formação universitária, em geral com formação prática vinculada ao mercado, ou passagem como alunos/monitores por projetos similares.

b) chegada ao projeto, em geral, por uma situação oportuna. Ou seja, muitos profissionais não procurou os projetos, e sim o contrário. Esse cenário vem mudando um pouco nos últimos anos, com a maior exposição decisiva que a EAP vem obtendo na mídia. De todo modo, continua a ser muito comum que um profissional jamais envolvido com tais práticas seja convidado a desenvolver, do zero, um projeto de ensino audiovisual para entidade ou instituição pública - e que o faça com total liberdade criativa e de execução.

c) liberdade para desenvolver o próprio trabalho, desde que em diálogo com o objetivo maior do projeto. Na prática, isso significa que coordenadores possuem grande autonomia para contratar (ou selecionar) professores, organizar o calendário de atividades e gerir as práticas pedagógicas, mas sempre em grande sintonia com os objetivos da entidade e zelando pelo cumprimento das expectativas e respeito aos valores das fontes financiadoras. No caso dos educadores, a liberdade é mais ampla, e 
respeitadas as diretrizes gerais construídas pelos coordenadores, ou em conjunto, os educadores em geral têm absoluta autonomia para criar suas práticas pedagógicas e geri-las no cotidiano.

d) modelo de interação com os alunos que sugere algum grau de horizontalidade, rompendo com os tabus que envolvem a atuação do professor da escola formal no sentido da criação de um ambiente participativo e, especialmente, afetivo, em que de lado a lado se percebe e permite os estabelecimento de relações que vão além da formalidade escolar, beirando o paradigma familiar.

Nesse sentido, destaca-se a urgência, de parte a parte, de algum reconhecimento de suas idiossincrasias, em processo no qual o aprendizado técnico depende diretamente do desenvolvimento por parte dos alunos de um entendimento maior de si e dos outros, e de suas relações. gUi Mohallem, educador também da ELCV e da Ouroboros, comenta, sobre sua atuação como educador da Oficina de Elétrica do IC, como a aceitação da sua homossexualidade por seus alunos implicou em grande transformação para todos, e em uma grande conquista para ele:

\begin{abstract}
Eu tinha muito medo de perder o amor dos alunos quando eles soubessem que eu era gay. [...] E aí a gente se beijou nessa festa, e os alunos viram, e eu meio que falei naturalmente com eles. Eu apresentei o Léo; eu não soube muito ser, e nem tentei tanto ser, natural, e não fui natural em relação a coisa. Eu estava me esforçando para fazer alguma coisa que eu queria fazer, mas eu não estava pronto ainda. Isso foi em um sábado. Na segunda-feira seguinte, eu estava em pânico de ir para a aula, para dar aula, mas nada aconteceu assim, ninguém falou nada, enfim, eu ouvi alguns comentários aqui e ali de que o professor de x é gay nas outras oficinas, mas na minha oficina ninguém falou nada. Daí "rolou" tipo um amigo secreto. Todo mundo leva um presente e todo mundo conta uma história, confessa uma história, conta uma história e quem se identificar com a história, ganha esse presente da pessoa e conta a sua história, mais ou menos assim. Na vez de contar a minha história, eu contei essa história, uma história da minha sexualidade, da minha dificuldade em lidar com isso, e na hora que eu contei, eu descobri que nenhum outro aluno, aléem dos que viram, sabiam, Porque eles não tinham contado. Olha que incrível! É muito amor isso né? Os meus alunos que viram, não contaram para os outros do que viram, respeitaram a minha intimidade, e eu fiquei mais emocionado com isso do que com qualquer outra coisa, e antes disso, eu já tinha feito um trabalho muito grande sobre preconceito com esses alunos, mesmo porque tinha "rolado" uma história com um aluno de maquiagem. (Depoimento verbal de Mohallem, 2009)
\end{abstract}

5. Grande criatividade pedagógica estimulada por longos e solitários planejamentos, tomados como momentos de ato criativo, implicando na realização de atividades altamente originais que promovem, nos alunos como em si mesmo, transformações positivas não apenas no que diz respeito aos aprendizados técnicos, mas também, e especialmente, no que diz respeito à descoberta e recriação de 
processos que permitem que se aprenda (sozinho) qualquer novo assunto. Em alguma medida, os educadores, em suas aulas lúdicas, buscam recriar para os alunos os próprios processos pelos quais passaram - na concepção da aula ou na descoberta de algo novo - em suas vidas. Assim, os educadores, em alguma medida, também pautam sua criatividade por suas próprias paixões - o que em si favorece o interesse e a paixão dos alunos também.

Em resumo: múltiplas origens, interesse indireto pelo tema, liberdade pedagógica extrema, modelo de interação que sugere alguma horizontalidade e grande criatividade pedagógica implicando em interesse e aprendizado integral.

É neste cenário, e também por outros motivos diversos, que se detecta o surgimento de desafios maiores, como a sobrecarga de trabalho, o isolamento dos profissionais, o eventual envolvimento afetivo entre profissionais e alunos,a necessidade de apoio aos alunos em sua vida pessoal e o uso criativo das potencialidades da avaliação.

i. Sobrecarga de funções. Em geral, tanto educadores como coordenadores concentram papéis diversos dentro da entidade. Educadores, em geral, realizam as atividades pedagógicas propriamente ditas e têm de dar conta também de todo um amplo universo de demandas, dos alunos (questões pessoais, indicações, orientação) e da entidade (relatórios, reuniões, visitas de parceiros e patrocinadores), etc. Já os coordenadores, se não realizam muitas atividades diretamente com os alunos, realizam atividades de um amplo espectro, que buscam dar conta de integrar todos os universos e por isso são, muitas vezes, os primeiros a entrar e os últimos a sair.

Essa sobrecarga se justifica especialmente pela já mencionada irregularidade dos financiamentos, que gera uma espécie de curto circuito: dificulta a manutenção e adequação das equipes e, paradoxalmente, implica na exigência pela constante ampliação dos impactos mensuráveis, que em geral são valorizados - dentre outros fatores - pelo número de alunos atendidos.

ii. Isolamento. Por mais que o desejo de integração entre os diferentes 
âmbitos (sala de aula, equipes pedagógica, de gestão ou suporte) seja bastante visível, a sobrecarga de funções citada acima costuma ter como implicação direta o isolamento de todos os profissionais em seus cotidianos específicos dentro da entidade, somente interrompido pelas não tão freqüentes reuniões pedagógicas e demais instâncias de atuação coletiva. A principais implicações de tal isolamento são um nível de liberdade pedagógica total, e um certo grau de solidão, na idealização, execução e avaliação dos próprios processos.

\section{iii. Experimentação afetiva que chega a superar as fronteiras socialmente}

estabelecidas. Dentro do cenário descrito acima, e nesse sentido em diálogo direto com situações análogas que ocorrem na educação formal, a sedução é um elemento presente às entidades da EAP. Talvez pela proximidade etária (monitores em geral não passam dos "vinte e poucos anos", e muitos coordenadores ainda não chegaram aos trinta), há grande incidência de situações envolvendo relações afetivas entre professores/coordenadores/monitores e alunos/ex-alunos nas entidades da EAP - nas entidades que coordenei, ou que foram relatadas a mim direta e indiretamente.

Trata-se de um assunto que, quando foi abordado, nas entrevistas, causou muitas vezes constrangimento, perceptível nos gestos e entrelinhas dos entrevistados. Josinaldo Medeiros, jovem educador da Abaeté que é também ex-aluno do Cinemaneiro e presidente do Cidadela, perguntado sobre a emergência de relações afetivas entre profissionais e alunos, reagiu com espontaneidade antes de responder: “Ai, meu deus do céu... Eu não sei... É muito subjetivo (risos)... Vai de cada um...”. (Informação verbal de Josinaldo Medeiros, 2009)

Nos questionários escritos, a questão gerou até alguma indignação, como se a própria sugestão da incidência de fato similar fosse em si algo antiético.

Mas o fato é que ocorre, e tem muitas implicações. A maior delas é o fato de que, como se trata de um grande tabu, as entidades em geral nunca falam do assunto antes de ele vir à baila na emergência dos fatos, exigindo muito jogo de cintura para o entendimento das situações e criação de procedimentos mais claros com relação ao tema. 
Como nas escolas, o envolvimento afetivo costuma ser implicitamente proibido nas entidades da EAP. Quando ocorre, são levados em conta dois critérios, que podem ser atenuantes ou agravantes: o aluno ser menor de idade, o que tornaria a relação um crime; e o curso ainda estar em andamento.

Quando o aluno é maior de idade, ou o relacionamento teve início após o término dos cursos, os profissionais são unânimes em afirmar e celebrar a liberdade afetiva e sexual destes, vistos como adultos e livres. Desde que, claro, não exista, de parte a parte, segundas intenções. O que, aliás, não seria característica desejável apenas nos relacionamentos oriundos de tais situações.

No meu ponto de vista, eu não tenho problema com isso não... Desde que os dois sejam maiores de idade, se completem, se gostem... Acho que às vezes, num processo de oficina, no âmbito educacional, isso prejudica muito... Depois, eu acho que se acontecer, legal... (informação verbal de Josinaldo Medeiro. 2009)

Por outro lado, os profissionais são taxativos no que diz respeito ao estabelecimento de relações em que, por um motivo ou outro, se percebe que existem interesses e motivações não exclusivamente afetivos, ou que surgiram de um potencial oportunismo do profissional - que poderia utilizar sua momentânea posição de poder para estabelecer uma situação de sedução que em outro contexto não se estabeleceria. Como comenta Carvalhosa:

\begin{abstract}
A gente está trabalhando na oficina com alunos que a faixa etária é entre 18 e 25 , todos maiores, quer dizer, para mim, a questão é o seguinte: se existe um abuso por conta do professor em relação a uma abordagem de uma relação desigual, se um professor ou um monitor não está usando do seu poder momentâneo para criar uma relação que não necessariamente seria de verdade... Eu acredito que - seja nas oficinas, seja no festival de curtas, seja no nosso grupo de monitores - se essa pessoa que está entrando em um relacionamento afetivo com um mestre, um professor, um orientador não está entrando em uma relação por motivos errados, quer dizer, no sentido de que aquilo pode ser um facilitador. (Informação verbal de Zita Carvalhosa obtida em 02 de dezembro de 2009)
\end{abstract}

O IC criar viveu uma situação clara, em que um educador se envolveu com uma aluna durante o curso. No caso, a história envolvia uma aluna extremamente tímida, e só foi descoberta pela equipe de gestão após o curso, e ambos os fatos foram considerados agravantes, e acabaram implicando no desligamento do profissional, não sem antes, contudo, gerar grande reflexão em toda a entidade: 
a gente julgou que se isso [o relacionamento entre o educador e a aluna] foi velado até o ultimo instante é porque existia uma percepção interna da parte desse educador de que ele estava fazendo algo que não era o melhor para aquela menina e para o grupo. A gente foi e voltou, não era uma decisão taxativa, porque nunca tinha sido discutida, mas isso foi muito importante, pesou muito. Também pesou o fato de que era uma menina muito tímida, muito fechada, muito na dela, não era uma menina super sedutora, que foi irresistível. A gente pensou que, para isso ter surgido ali, ele se valeu do encantamento que o educador tem; acho que isso é outra coisa, a gente chegou na sensibilidade de que é injusto um educador se valer dessa sedução que o papel dele tem nesse processo com a situação específica desse publico que chega muito mais fragilizado do que chega uma menina em uma faculdade. (Informação verbal de Danielle Fiabane, 2009)

Outra característica é levada em conta: a transparência. Há também outros relatos informais de situações análogas que, uma vez comunicadas pelos profissionais às entidades, se desenrolaram de maneira mais ponderada, levando em conta a possibilidade do surgimento de uma relação séria e duradoura. Como Fiabane sugere que poderia ter ocorrido:

\begin{abstract}
A gente discutiu isso: "ah não, mas eu casei com meu professor". Acho que a Kika casou com o professor dela. Não sei. Alguém aqui casou. A Kika nem estava aqui na época. A Camila casou com o professor dela e na época era educadora aqui, mas ela estava na faculdade, ela tinha outra idade, e a faculdade tem isso abertamente como aceito. Eu acho que talvez se a coisa tivesse fluido de uma outra forma, a discussão teria sido outra; se isso tivesse sido trazido de antemão pelo educador que estava naquela situação (Ibidem)
\end{abstract}

Busca-se lidar com a questão ponderando os papéis de profissionais e alunos na situação. Ainda que a tendência geral seja de responsabilização única do educador, sabe-se que há também forte assédio dos alunos com relação a estes, estabelecendo muitas vezes situações em que são confrontados com o desejo do aluno até de forma ostensiva. Como comenta Paula Kimo, coordenadora da Oficina de Imagens:

\begin{abstract}
Eu acho que acontece dos dois lados, tanto sedução do professor quanto da professora, do aluno e da aluna. [...] Eu que essa relação acontece, essa sedução acontece principalmente, talvez mais com o professor sendo seduzido, porque, para o aluno, aquilo é uma coisa da infância, tão natural...[...] Isso não seria impedimento nenhum de uma relação, mas, enquanto a gente estiver trabalhando como educadores, de uma formação assim, é até difícil de falar. Eu, no fundo, acho meio careta de ter, mas tem certa responsabilidade, a gente tem que pensar duas vezes, porque é natural do ser humano essa sedução, essa relação de sedução em qualquer uma das idades, eu acho que com os meninos é impressionante. Com 12, 13 anos eles já estão super interessados uns nos outros, se abraçam, se namoram, se beijam, muito mais liberdade que a classe média. Quem sai da classe média para ensinar e vê isso acontecendo fica até assustado, mas eu acho que é uma questão super natural. [Sobre fornecer o número de celular] Eu evito ao máximo, mas é que meu celular sempre esteve aberto, não sei por que, acho que é meio uma segurança minha, porque é um meio de comunicação como outro qualquer... Eu acho que tem o limite, mas meu celular sempre esteve aberto na Fundação, se alguém quisesse me atingir, sempre me atingia por isso. (Informação verbal de Paula Kimo, 2009)
\end{abstract}

Afetividade não pode implicar em um clima erotizado/sensualizado. Nesse caso, há uma inevitável tendência a uma confusão de papéis, bem como uma grande perda de foco, tanto pelo aluno como pelo educador, implicando, por fim, em perda 
significativa para todos os envolvidos.

Perder o respeito é perder o controle. Aluno, mesmo adulto, é um bicho imprevisível, que se apaixona de 5 em 5 minutos por um professor diferente. Natural, é uma relação de admiração, de pedestal, somos (como educadores), de alguma forma, sedutores para nosso público. Falamos no grupo sobre isso sempre quando construímos e definimos nossa metodologia quando isso quase aconteceu (e quando isso de fato aconteceu). Esse deve ser um assunto constante. O assédio do educando pode ser desconcertante e catastrófico, pode tirar um educador do seu eixo e pôr em risco todo um planejamento. Mais uma vez, o educador não está lá para isso, ele tem responsabilidades, funções e mais tantos outros alunos para dar atenção - principalmente se ele acordou ou ajudou a construir essa metodologia. O diálogo e a não repreensão agressiva e autoritária (não sei como colocar melhor) são as melhores vias. É preciso dialogar com o educando, perguntar e entender primeiro o que aconteceu. Ele deve ser ajudado a cortar o assédio e voltar para seu foco original. Queira ele ou não, tenha pedido ajuda ao coordenador ou não. Quando o projeto acabar e ambos não forem mais da responsabilidade do coordenador, eles que se resolvam. Não posso impedir o amor, essa é minha força vetor. (SANTONIERI, 2009)

Por fim, se o aluno é menor de idade, trata-se de crime, e em tais circunstâncias, não há quem defenda a posição de um profissional.

$\mathrm{Na}$ verdade, tem uma relação de idealização com o professor, e a gente trabalha com um público mais novo, então é uma coisa que não "rola" de maneira nenhuma. (Informação verbal de Victor Santos,2009)

Nos três últimos casos citados, em geral, o profissional tende a não permanecer na entidade.

Em resumo: em virtude de todo o ambiente participativo e afetivo criado nas entidades da EAP, há a emergência de relacionamentos afetivos envolvendo profissionais e alunos, à qual as entidades vêm reagindo de forma a respeitar diferentes critérios. No caso de ex-alunos maiores de idade, não há maiores consequências, e há até certa celebração, quando as relações tornam-se duradouras; no caso de alunos e/ou menores de idade e/ou relacionamentos forjados em intencionalidades duvidosas, os profissionais são, em geral, desligados das entidades.

ii. Responsabilidade por aqueles que cativam.

Para o Pequeno Príncipe, personagem da obra de Saint Exupéry, as relações são marcadas pelo fato de que todos seriam igualmente estranhos uns aos outros até que, por um motivo ou outro, alguém cativa e é cativado, fazendo com que, da estranheza, se transite para a familiaridade. Teria dito a raposa para o príncipe, e esse a Exupéry: "Os homens esqueceram essa verdade, mas tu não a deves esquecer. Tu te tornas eternamente responsável por aquilo que cativas". (SAINT-ÉXUPERY, 2006, p. 
Essa é uma questão premente para todos os educadores que atuam no atendimento a públicos carentes: até onde deve ir sua atuação no auxílio aos alunos em questões de sua vida pessoal? Como no caso citado por Simone Lima, da Aldeia, se deve auxiliar os alunos mesmo quando o problema é, por exemplo, com a justiça?

Já aconteceu exatamente de o aluno faltar à aula, e a mãe chegar, no horário da aula, para justificar a ausência do filho, dizendo que ele foi preso. Bom, nesse caso, tentei auxiliar na resolução do problema, que não era tão simples. O rapaz não era réu primário, o que complicou; mas utilizei de todos os recursos da lei, para o jovem sair da prisão. Em problemas desta natureza é bom saber das versões do fato até agir. Creio que um advogado esclarece, orienta. Mas a instituição deve tomar uma posição e ser transparente com os envolvidos, e tomar atitude, se assim for necessário. (Questionário com Lima, 2009

Essa é uma questão diretamente influenciada pela forma através da qual as entidades lidam com o tema, que é bastante irregular: entidades localizadas fisicamente dentro de comunidades carentes e, portanto, mais próximas das residências dos alunos tendem a oferecer mais mecanismos de auxílio direto. Entidades localizadas no centro das cidades ou em bairros distantes das comunidades que efetivamente atendem, tendem a ter uma atuação mais sóbria e discreta no auxílio aos alunos.

Para Danielle Fiabane, do Instituto Criar, o principal critério deve ser a equidade, oferecendo a um o que se pode oferecer a todos. No entanto, ela sugere também que existe a necessidade de se lidar com alguma flexibilidade nesse âmbito:

\begin{abstract}
Não é o papel da instituição dar comida para as pessoas; não podemos fazer isso para um, senão teremos que fazer para todos, que é a minha preocupação o tempo todo. Não tem como, então, tem um limite aí entre o que é a ética pessoal e o que pode ser da ética da instituição, e eu acho que a solidariedade e o respeito aos valores humanos sempre vão fazer com que a nossa política institucional seja flexível, aquilo que o bom-senso exige sabe? (Informação verbal de Danielle Fiabane, 2009)
\end{abstract}

Fazendo uso de uma rede de parceiros, algumas entidades buscam oferecer auxílio, quando necessário, dentro dos recursos possíveis - especialmente legal, médico e profissional.

Quando surge algum problema pontual que não podemos ou não sabemos como resolver, buscamos parcerias de outras instituições ou serviços que têm expertise no assunto. Mas, geralmente, o educador dito social já tem o traquejo de como lidar em certas situações. A relação de educador e educando é de troca o tempo inteiro. São sentimentos mais próximos; a família também é mais próxima; os meninos e os educadores acabam vivenciando alguns programas compartilhados. Existem pais que até nos procuram para conversar. É uma experiência que considero muito diferenciada da escola formal. 
As entidades, ao assumir esse papel enquanto coletivo - a entidade assume responsabilidade pelos alunos -, buscam também evitar que educadores e coordenadores o façam de maneira independente e menos produtiva para todos. Quando a entidade se exime da responsabilidade, educadores e coordenadores tendem a assumi-la - "sentem-se responsáveis por aqueles que cativam" - com menos recursos. Obtém resultados inferiores e, cansados, rendem menos para a própria entidade.

iii. Manter as atividades em sintonia com os objetivos e o interesse dos alunos, especialmente a partir da realização, sistematização e análise de diferentes estratégias de avaliação.

Essa é uma característica inerente aos processos pedagógicos criativos da EAP: muitas vezes, os alunos não conseguem ter clareza de que estão aprendendo, pois desconhecem vias alternativas à forma bancária de aprendizado escolar.

Existem ao menos três instâncias distintas de avaliação na EAP:

(a) avaliações à atuação da entidade e de seus profissionais, pelos alunos;

(b) auto-avaliações (especialmente pelos alunos);

(c) avaliações amplas, realizadas por profissionais externos à entidade, e voltadas aos resultados dos processos.

Aqui nos interessa especialmente observar como avaliações e auto-avaliações, especificamente no âmbito dos alunos, vêm funcionando como importantes ferramentas pedagógicas - especialmente para garantir que adequações importantes sejam feitas durante o processo, e não depois.

A gente vem buscando formas de avaliar junto com eles também... Como é todo o processo de aula, o que foi "bacana", o que não foi, do que eles sentiram falta... Então a gente sabe que, quando a gente diminuiu o curso, o conhecimento que ia ser passado para eles, obviamente também diminuiu. Sempre existe uma prioridade de trabalhar com a questão crítica e criativa; trazer um pouco a ludicidade (sic) e, às vezes, durante o processo, ir monitorando. Na verdade, não adianta nada no final avaliar que a coisa não funcionou. (Informação verbal de Miriam Machado, 2009) 
Além das avaliações escritas ou verbais mais formais, que em geral têm como objetivo avaliar processos mais amplos, há uma prática comum de realizar uma espécie de avaliação constante do próprio processo de aprendizado, um constante questionar meta-educativo. Dessa forma, se torna fundamental criar o hábito de questionar os alunos: "Por que essa atividade foi feita? O que eu (educador) tinha em mente quando propus isso a vocês? Por que fiz dessa forma e não de outra? O que vocês imaginam que eu queria despertar? O que vocês, de fato, aprenderam nessa aula?"

O momento de avaliação é também um momento em que o educador induz os alunos no entendimento do processo pelo qual está passando e, nesse momento, se expõe, assume seus objetivos, descreve parte do percurso que percorreu para elaborar a aula e qual sua avaliação final com relação ao sucesso ou fracasso da aula. É um momento de muita sinceridade em que essa exposição, esse "making-of" da aula, essa reconstrução coletiva do sentido da atividade cumpre um papel fundamental de desmistificação da criação pedagógica e de efetiva compreensão dos educandos de que se trata de uma etapa em um processo maior.

O educador sabe que uma situação pedagógica que não seja amarrada por uma auto-avaliação coletiva final perde grande parte do seu sentido e potencial de transformação. E exatamente por isso, no processo de planejamento artesanal, fará simulações, estipulará o tempo necessário para cada dispositivo e sempre reservará tempo suficiente para essa atividade.

A realização de avaliações sistemáticas evita o complexo de "Daniel San”, em que os educandos revoltam-se com os educadores por acreditarem que eles fazem mais perguntas do que dão respostas e por não perceberem, por diversos motivos, seu aprendizado no momento em que ocorre - assim como acontece com o personagem do filme "Karatê Kid".

Quando ele atuava como educador e eu como coordenadora no Instituto Criar, em 2006, o educador gUi Mohallem propôs uma mudança na forma de avaliar seus aprendizes no segundo trimestre. Buscando, justamente, evitar o "complexo de Daniel 
San", Mohallem compôs a nota do primeiro trimestre da seguinte maneira: havia pedido aos aprendizes que elaborassem uma auto-avaliação e sugerissem uma nota. (A avaliação divide-se em Não Satisfatório, Satisfatório e Plenamente Satisfatório). A partir da auto-avaliação, gUi escreveu uma carta para cada aprendiz e deu uma nota final, justificada no texto.

Ele pediu a opinião desta pesquisadora, então coordenadora pedagógica do IC, sobre inverter a proposta: ele escreveria uma carta e avaliaria o aprendiz, que responderia, e auto-sugeriria uma nota, que seria soberana. A ideia me pareceu, então, simples e interessante, e adequada ao processo de formação daquela turma específica, naquele momento - além de ser um excelente "piloto de testes" para uma ideia deveras interessante. gUi aplicou a proposta, e teve um resultado excelente e curioso. Poucos aprendizes atribuíram-se Plenamente Satisfatório - somente aprendizes extremamente dedicados e conscientes de seu grau de participação e desempenho. Alguns aprendizes, cuja nota indicada pelo educador seria PS ou S, atribuíram-se notas menores, avaliando com bastante clareza, e até excesso de rigidez, seus próprios desafios. A principal conquista dessa intervenção foi a corresponsabilização do aprendiz em seu processo formativo, simbolizado por sua participação ativa na avaliação - como queria Freire. ${ }^{56}$.

\subsection{Estratégias pedagógicas}

As propostas da EAP são promovidas a partir da articulacão entre atividades pedagógicas de naturezas diversas, em dois formatos básicos:

a) 1. oficinas com objetivo concreto, realizado a partir de etapas planejadas (por exemplo, realização de uma oficina completa voltada para a realização de curtas-metragens);

\footnotetext{
${ }^{56}$ A prática educativa em que aquele respeito, que sei dever ter ao educando, se realize em lugar de ser negado. Isto exige de mim uma reflexão crítica permanente sobre minha prática, através da qual vou fazendo a avaliação do meu próprio fazer com os educandos. O ideal é que, cedo ou tarde, se invente uma forma pela qual os educandos possam participar da avaliação. É que o trabalho do professor é o trabalho do professor com os aprendizes, e não o trabalho do professor consigo mesmo. (FREIRE, 1989, p. 64)
} 


\section{b) 2. oficinas compostas por sequência didática ${ }^{57}$ envolvendo} atividades e objetivos diversos (cadeia planejada de atividades, mas com múltiplas possibilidades de caminho).

Desenvolvem-se, em cada tipo de abordagem, atividades pedagógicas, aulas, exercícios e jogos, voltados aos diferentes temas e técnicas tangentes e diretamente envolvidos no fazer audiovisual.

Promovem-se atividades em espaços diversos:

Salas de aula tradicionais (mesas, cadeiras, lousa)

Espaços abertos /ao ar livre (senta-se no chão)

Espaços técnicos da área audiovisual: estúdio de gravação, estúdio de som, ilha de edição

Espaços coletivos da entidade (sala de informática, de projeção, biblioteca)

Espaços Públicos

Há atividades pedagógicas clássicas:

Aulas

Exercícios

Estudos de meio

E outras mais alternativas:

Jogos Lúdicos

Rodas de conversa

Assembléias $^{58}$

E de diferentes perfis:

Expositivas - exclusivamente teóricas

Teórico-práticas (Da prática parte-se para a teoria)

Prático-teóricas (Da teoria parte-se para a prática)

Práticas - exclusivamente

\footnotetext{
${ }^{57}$ As situações de aprendizagem inscrevem-se em dispositivos e sequências didáticas, as quais são subordinadas a um contrato pedagógico, e às regras e instituições internas à escola. (PERRENOUD, 1999a, p. 33)

${ }^{58}$ Pode ser considerada também uma estratégia de gestão.
} 
Nas atividades, e a partir delas, eventualmente, promove-se a realização de exercícios sobre assuntos e objetos diversos:

Individuais;

Coletivos;

Colaborativos - todos criando e atuando conjuntamente.

As atividades têm como assuntos/objetos:

Roteiro, Câmera/Fotografia, Som, Produção (em praticamente todos os projetos);

História do Cinema/Audiovisual, Linguagem Audiovisual, Direção, Edição (Teoria e Prática), Documentário (muito frequentes);

Assistência de Direção, Direção de Arte, Trilha Sonora (incomuns, porém há ocorrências)

dos âmbitos intelectual, social e emocional, como Estudos Sociais, Empreendedorismo $^{59}$, Profissionalização ${ }^{60}$, Comunicação e Expressão, entre outros. (especialmente em alguns perfis de oficina)

Há uma prática frequente de exibição de filmes, de curta ou longa-metragem, que remete ao cineclubismo, cinéfilo como militante. As exibições, em geral, ocorrem em um ou mais dos espaços citados:

Salas de aula, onde também ocorrem as demais atividades do curso - exibição em TV ou a partir de projetor, utilizando como tela um tecido branco, telão ou parede.

Quadra ou outro espaço aberto e interno à entidade ou projeto parceiro-sede.

São mais incomuns; porém, há registros da promoção de tais atividades em:

Salas de Projeção especialmente criadas para esse fim.

Espaços públicos, como praças, parques e estacionamentos.

Locais de passagem, inusitados.

Promove-se geralmente a exibição de um ou mais dentre os perfis abaixo:

\footnotetext{
${ }^{59}$ Entende-se por "empreendedorismo" um conjunto de práticas voltadas à inserção laboral por meio do empreendimento sustentável de projetos pessoais.

${ }^{60}$ Entende-se por "profissionalização" um conjunto de práticas voltado à inserção laboral por meio do aprendizado técnico de um ofício.
} 
Filmes brasileiros de longa-metragem, especialmente recentes; e ou

Filmes e Vídeos de Curtas-Metragens profissionais, especialmente brasileiros; e ou

Vídeos de Curta-Metragem produzidos em outros projetos e entidades;

Filmes brasileiros e estrangeiros de épocas e gêneros representativos para criação de um panorama histórico, como: Primeiro Cinema (Lumiére, Méliès); Expressionismo Alemão; Cinema Noir; Melodrama Clássico; Neo-Realismo Italiano; As Chanchadas Brasileiras; As Nouvelle Vagues Francesa, Alemã, Japonesa; Cinema Novo Brasileiro e Latino Americano; Filmes de Guerra; Cinema Brasileiro Marginal; Cinema Contemporâneo.

Filmes e Vídeos alternativos, militantes, independentes, proibidos ${ }^{61}$, enfim, produtos audiovisuais de difícil acesso e conteúdo político-polêmico.

Vídeos produzidos na própria oficina.

A intensidade das atividades educativas, grosso modo perceptível na relação entre duração e carga horária, tem implicações decisivas na articulação entre o formato básico de cada projeto e os diferentes elementos pedagógicos mobilizados.

Nos próximos Subcapítulos, apresento uma síntese criativa das práticas pedagógicas e sequências didáticas dos projetos, a partir de três perfis de oficina definidos a partir dos critérios de duração e carga horária, o que descreve também o aspecto da intensidade dos projetos:

Perfil 1: Ciclo curto (até 1 mês / 30dias/ até 160h/aula)

Perfil 2: Ciclo e carga horária intermediários (de 3 meses a 1 ano / 90 a 360 dias e até $400 \mathrm{~h} / \mathrm{aula})$

Perfil 3: Ciclo intermediário a longo, e ampla carga horária (de 90 a mais de 360 dias, de $400 \mathrm{~h}$ a mais de $800 \mathrm{~h} / \mathrm{aula})$.

É importante destacar que tais perfis são categorias de análise criadas por mim em função das similaridades encontradas. Trata-se, em alguma medida, de definições

\footnotetext{
${ }^{61}$ Por exemplo, o filme "Di-Glauber", de 1977, de Glauber Rocha, que retrata o enterro do pintor Di Cavalcanti, filme que sofreu processo judicial por parte da família do pintor, e que por isso foi tirado de circulação. O filme, durante anos, foi um mito para os estudantes de cinema, e muitas vezes era exibido clandestinamente para os alunos de diferentes oficinas.
} 
bastante ampliadas e um tanto arbitrárias - que visam, em última análise, permitir a criação das oficinas imaginárias e tipos ideais.

\subsubsection{PROJETOS DE PERFIL 1 - CICLO CURTO E ALTA CARGA HORÁRIA RELATIVA (20 a 160H/AULA) ${ }^{62}$}

Dezesseis entidades que participaram do mapeamento realizam projetos de ciclo curto e carga horária máxima de 160h/aula, como se vê na lista abaixo:

Duração intermediária: 1 a 30 dias

Carga horária: 20 a 160h/aula

Total: 18 projetos $(25,71 \%)$

37 Festival de Inverno da UFMG: Oficina de Iniciação ao Vídeo - Diamantina Cidadania $(\mathrm{MG})$

Abaeté Estudos Socioambientais: Observatório Humano Mar (RJ)

Amacine Futuro Cineastas: Amacine Futuros Cineastas (AM)

Associação Cultural Kinoforum: Oficinas Kinoforum de Realização Audiovisual (SP)

Boteco Cinematográfico LTDA / Cooperativa de Cinema Fora do Eixo Cinemaneiro (RJ)

Buriti Filmes: Oficina Itinerante de Vídeo Tela Brasil (SP)

Canal Futura / Fundação Roberto Marinho: Geração Futura (RJ)

Coletivo CineEsquemaNovo: Oficinas Audiovisuais (RS)

Coletivo Filmagens Periféricas (SP)

Coordenação de Cinema, Vídeo e Fotografia da Secretaria Municipal de Cultura de Porto Alegre: Olho da Rua e Projeto de Alfabetização Audiovisual (RS)

Grupo Kino-Olho: Oficina de Difusão Cinematográfica (SP)

Imaginário Digital: Oficinas Imaginação Digital (RJ)

\footnotetext{
${ }^{62}$ Os questionários da segunda etapa e as entrevistas presenciais serão os instrumentos mais utilizados neste Subcapítulo, uma vez que as informações contidas no Questionário Geral dão conta apenas parcialmente das informações relevantes nesse contexto.
} 
ITEC - Instituto Técnico de Estudos Cinematográficos: Projeto Cinema Para Todos $(\mathrm{RN})$

Kinoarte - Instituto de Cinema e Vídeo de Londrina: Oficinas Kinoarte (PR)

Organização Neo Humanitarismo Universalista: Núcleo de Cinema Ambiental (SP)

Ouroboros Cinema e Educação: Oficina de Documentários do Centro de Cultura Judaica (SP)

Projeto Curta Cultura São Paulo: Curta Cultura São Paulo (SP)

Vídeo nas Aldeias (PE)

\section{Características gerais}

\section{Características gerais}

Em projetos deste perfil, em geral, realiza-se um ciclo de formação intenso, com aulas longas (mais de 4h por dia), realizadas em dias sucessivos. O ciclo é totalmente orientado pela realização, no final do curto processo, de produtos audiovisuais. Dessa forma, se estabelece uma estratégia em que um objetivo concreto (a realização de vídeos) é promovido a partir de uma série de etapas planejadas - que, em geral, envolvem projeções, aulas - de perfis variados (e exercícios), individuais e coletivos.

Os alunos escrevem argumentos, que são escolhidos em votação ou integrados criativamente. E a partir dos roteiros são compostos os grupos. Como comenta Frederico Cardoso, coordenador do Cinemaneiro, um dos projetos com esse perfil:

Muitas vezes escolhem-se pelas ideias: todo mundo escreve um argumento, e as cinco melhores ideias - de acordo com a turma, ela mesmo que escolhe - vão ser desenvolvidas; vão sair cinco roteiros, e esses vão passar por uma nova eleição. Cada turma vai escolher o roteiro a ser filmado. Às vezes não, às vezes as pessoas já têm uma ideia que é a melhor de todas e querem que a turma toda trabalhe em conjunto naquele roteiro (Informação verbal de Cardoso a Souza, 2009) 
Ao longo da oficina, o aluno aproxima-se da função que mais lhe interessa. Isso não impede que, em muitos grupos, diferentes funções como roteiro, direção, produção e outras sejam exercidas de forma coletiva em sistema de rodízio (cada aluno opera a câmera em cenas distintas, o mesmo com a operação de som, etc.). No entanto, o mais comum é que, aos poucos, os alunos escolham uma ou duas funções, e as realizem até o final.

Em projetos com este perfil manifestam-se inúmeros tipos de conflito de relacionamento entre os alunos, assim como dificuldades individuais nos âmbitos intelectual, emocional e social. A estrutura da oficina, em si, é muito exigente nesse sentido: no processo coletivo de criação dos roteiros, os alunos trazem suas ideias, e logo têm que se desapegar, pois várias ideias tornam-se uma, e ele precisa aprender a fazer negociações e ceder. Como propõe, em outras palavras, a coordenadora das Oficinas Tela Brasil e das Oficinas Ouroboros Marina Santonieri:

Saber conviver e trabalhar em grupo é o grande desafio, além de se perceber como agente criativo. É preciso curiosidade, abertura, flexibilidade, desapego, concentração, saber se impor e saber ouvir, criar mesmo sem estruturas ideais, ser meio macunagiver ${ }^{63}$, geek $^{64}$. O ideal é ter um conjunto que se complete, agregando as habilidades de cada um. Comprometimento, foco, abertura e reflexão crítica.. (Informação verbal de Marina Rodrigues Santonieri, 2009)

Situações que exigem o exercício do diálogo são vividas ao longo de todo o processo e, naturalmente, os alunos tendem a crescer e aprender sobre si e sobre conviver com os outros. No entanto, em oficinas deste perfil, são ainda bastante incomuns atividades especificamente voltadas ao desenvolvimento pessoal; o crescimento dos alunos neste âmbito ocorre, antes, a partir das características intrínsecas ao perfil do projeto.

Uma oficina imaginária, sintetizando características bastante comuns em

\footnotetext{
${ }^{63}$ Macunagiver é um neologismo formado pelas palavras Macunaíma, título e personagem do livro de Mário de Andrade, e Macgiver, personagem interpretado pelo ator Richard Dean Anderson na série homônima apresentada no Brasil nos anos 1980, com o título de "Profissão Perigo". Na série, Macgiver é um agente secreto diferente, que não carrega arma de fogo e, com grande conhecimento científico, é capaz de improvisar as mais diferentes armas e dispositivos com elementos simples do cotidiano - as chamadas "gambiarras". O neologismo sugere uma espécie de cientificidade malandra, ou seja, um meio de aproximação científico adaptado ao "jeitinho" brasileiro.

${ }^{64}$ Geek é um termo em língua inglesa que remete à postura séria e comprometida de jovens com grande interesse por tecnologia e programação de computadores.
} 
Oficinas deste perfil, iria pressupor a seguinte série de etapas planejadas e sequenciais:

\section{Atividade especial de abertura ou uma atividade pedagógica especial}

As Oficinas Humano-Mar possuem uma atividade de abertura absolutamente notável: os alunos entram na sala de aula, que está no escuro. Todos instalados, o educador acende uma lanterna e começa a iluminar o rosto dos alunos, enquanto uma câmera filma essas imagens e as transmite através de um projetor para um telão. $\mathrm{O}$ educador realiza uma série de perguntas abstratas cujas respostas servem de ponto de partida para uma reflexão sobre linguagem audiovisual. Como comenta Igor Barradas, coordenador do projeto:

Quando a gente termina isso (está tudo escuro ainda), a câmera vai pra mim, eu pego uma câmera pequena [...] e falo: "essa aqui é a câmera principal, uma das principais ferramentas pra se fazer um filme. Fazer cinema é com ela! É o seu lápis, é o lápis do poeta, é o quadro do pintor, é a principal ferramenta!" [...] Aí eu coloco a câmera no meio da sala, saio de perto e pergunto: "quem se atreve?" [...] Aí sempre tem um que vai lá, entende a mensagem e pega a câmera. Aí a gente acende as luzes e fala: "olha gente, cada um tem 3 minutos de imagem pra fazer... [...] vão aonde vocês quiserem. Vocês vão ter que sintetizar alguma coisa em 3 minutos." Aí eles saem... E aí a câmera vai rodando na mão de cada um. O máximo que a gente fala é onde fica o "rec" e o "zoom", e a gente encaixa a mão deles na câmera. [...] Não damos mais noção nenhuma, saímos, e ficamos só observando, só assistindo. (Informação verbal de Igor Barradas, 2009)

\section{Ou uma Exibição}

Exibe-se, em geral, curtas ou longas-metragens brasileiros, possivelmente até vídeos feitos em outras oficinas - do próprio projeto ou outros similares -, ou realização de atividade análoga, voltada para despertar a sensibilidade dos alunos.

A exibição pode ocorrer na abertura da oficina, como uma sensibilização. Como destaca Zita Carvalhosa, produtora do Festival Internacional de CurtasMetragens de São Paulo e das Oficinas Kinoforum, com relação ao objetivo histórico do projeto: 
que a gente levava curtas brasileiros em formato de cinema mesmo; era uma projeção de cinema em um espaço público para que as pessoas que tivessem se inscrito nas oficinas pudessem assistir um pouco dessa produção, que a gente passava no festival de curtas, e reagir a ela. (Informação verbal de Zita Carvalhosa, 2009)

Exibições podem ocorrer também ao longo dos primeiros dias das Oficinas. Nesse caso, as exibições, em geral, integram aulas sobre temas diversos, e possuem uma possibilidade de abrangência histórica bastante pequena, exigindo dos educadores capacidade de síntese e a realização de escolhas - na impossibilidade de se realizar um panorama realmente extensivo. Em geral, as aulas são ministradas pelos mesmos educadores que posteriormente ministrarão aulas técnicas e de linguagem.

O projeto Olho da Rua, promovido pela Secretaria de Cultura de Porto Alegre, buscou contornar essa dificuldade de estabelecer um panorama realizando uma grande quantidade de exibições, como explica a coordenadora Maria Angélica dos Santos: "Propiciamos a exibição de quase uma centena de curtas de diferentes gêneros e autores como forma de construir um repertório que permitisse impulsionar o processo criativo”. (Questionário com Maria Angélica Santos, 2009)

Em Oficinas Temáticas, ou com especial dedicação ao documentário, ocorrem aulas específicas sobre o tema que incluem exibições e abordam simultaneamente sua história e elementos de linguagem, já realizando provocações que auxiliarão, posteriormente, na criação dos vídeos. Como comenta Barradas:

\footnotetext{
$\mathrm{Na}$ aula de documentário, a gente usa como roteiro os modos de documentário. E vai mostrando, exibindo, falando e conversando, fazendo paralelos com jornalismo de TV e tentando quebrar essa coisa de jornalismo de TV, que é muito forte [...] "Você gosta de documentário?", "Gosto, sempre vejo o Globo Repórter..." a gente tenta quebrar isso de qualquer forma... (Informação verbal de Igor Barradas, 2009)
}

3. Exercício individual ou coletivo lúdico de gravação de imagens - ou primeiro contato com a câmera, ministrado por professor de perfil mais técnico ou ex-aluno do projeto em formação como educador. Em alguns projetos, antes do exercício, propõese uma situação lúdica, provocativa, que instigue a curiosidade e desperte o interesse dos alunos. Um bom exemplo vem de um exercício realizado pelo ex-aluno e ex- 
monitor do Instituto Criar, atualmente educador e colaborador pedagógico das Oficinas Tela Brasil, Wagner Klebson. O exercício chama "Decupando nosso filme na cabeça”. E prevê, segundo relato do educador, o procedimento é o seguinte:

Pedir que todos fechem os olhos e ouçam o que eu vou ler (uma parte de um roteiro), imaginando como gravariam aquela cena. Em seguida, quando eu tocar a mão de um deles, enquanto leio novamente a cena, este terá que descrever um plano apenas desta cena. (Relatório Oficinas Tela Brasil, 2009)

O exercício prático é sempre sucedido por um momento de reflexão crítica, de avaliação, em que são construídos, coletivamente, os primeiros conceitos. Como comenta Barradas, com relação aos exercícios práticos realizados nos primeiros dias de aula:

Aí a gente volta pra sala de aula e assiste tudo, e vai comentando em cima, muito com a mensagem de que "não há erro". "É tudo linguagem"; "a cada minuto, qual a sensação de estabilidade, que sensações que causam isso?" [...] Nessa aula, é praticamente eles que falam; a gente só fica provocando: "esse vídeo, que vídeo é esse?" Cada um inventa uma história, então às vezes eu falo que essa aula é "caômentario",65, algo como inventar justificativas para você criar uma defesa do seu vídeo. (Informação dada por Igor Barradas, 2009, pp. 4-5)

Klebson destaca também a importância de que, nesse processo, se encontre um equilíbrio entre a sua visão pessoal e a do grupo:

Prosseguiremos fazendo isso até que a cena tenha uma decupagem. No fim, faço um debate em torno da seguinte ideia: Quando fotógrafo, costumo dizer que estou guardando pedaços dessa história que se passa bem na minha frente. Por isso, acho que todas as minhas fotos são muito pessoais. Não consigo ver nenhuma delas como algo que fiz sem ter um pouco de mim. Então me pergunto se quando estamos fazendo câmera em um filme o mesmo não acontece. Na minha opinião, sim, acontece. Mas podemos, além dessa bagagem natural, colocar neste filme uma cara escolhida por nós e por outros componentes da equipe (Relatório Oficinas Tela Brasil)

É nesse exercício, também, que a equipe de educadores em geral detecta os alunos com maior interesse pela operação da câmera - e que muitas vezes acabarão assumindo tal papel na equipe por sugestão da própria equipe: “A gente faz um mapeamento mais ou menos nesse sentido: a gente mapeia os câmeras, quem tem a mão firme, e quem tem o olhar”. (Informação dada por Igor Barradas, 2009)

\footnotetext{
${ }^{65}$ Neologismo criado a partir da contração das palavras "caô" (gíria bastante comum no Rio de Janeiro, e que sugere algo como "enganação", "mentira") e "comentário".
} 
Aula expositiva teórica sobre História do Cinema / Audiovisual, muitas vezes envolvendo a exibição de filmes (como citado) e já integrada a reflexões sobre aspectos gerais de linguagem, como enquadramentos, movimentos de câmera e diferentes tipos e padrões de montagem. Em geral é ministrada pelo coordenador do projeto ou pelo professor responsável pelas disciplinas de linguagem (Roteiro, Direção, Teorias da Edição). Trata-se de aula pouco comentada nas entrevistas e questionários, mas que, pela minha experiência, é absolutamente frequente em oficinas deste perfil - muitas vezes integrada às exibições citadas anteriormente.

4. Aula teórico-prática de Roteiro. Como em praticamente todos os âmbitos pedagógicos da EAP, o roteiro não é considerado apenas um tema para o qual se requer um aprendizado técnico. Acredita-se que, para desenvolver as habilidades necessárias à redação de roteiros, é necessário mobilizar uma nova forma de apropriação conceitual e de "significação do mundo". Dessa forma, se busca realizar atividades lúdicas que surpreendam os alunos e constituam desafios para estimulá-los intelectual e conceitualmente.

Uma atividade desenvolvida pelo educador e ex-coordenador das Oficinas Tela Brasil Henry Grazinoli sintetiza bem esse espírito lúdico (neste caso, em uma perspectiva metalinguística):

A sala de aula fica de portas abertas, e o educador não está. Os educandos entram e se acomodam. Subitamente, o educador irrompe na sala de aula e começa a escrever no flipchart um roteiro, no qual descreve em linguagem cinematográfica o que está ocorrendo na sala de aula até aquele momento, e sugerindo o que deve acontecer a seguir:

"Sala de aula. INT. Dia. Um grupo de alunos espera o início da aula. Um professor barbudo (cerca de 30 anos), entra na sala de aula e começa a escrever um roteiro no flipchart. Em seguida, ele se volta aos alunos e diz: 'Bom dia, pessoal! Essa é a primeira aula do curso de roteiro cinematográfico. Vamos escrever um roteiro coletivo. Agora é com vocês'. O professor entrega a caneta a um aluno jovem, de boné azul, que levanta e vai até o flipchart. O professor se senta.

O professor realiza as ações que descreveu no flipchart, e após entregar a caneta para o aluno de boné, se senta e aguarda que ele dê sequência a história.

Após cerca de trinta minutos, em que os alunos se revezaram no flipchart, exercitando a linguagem recém-descoberta, o educador recebe a caneta e encerra o roteiro. Passa então a conversar livremente com os educandos, e a debater com eles os porquês de a aula ter sido realizada daquela forma: 
'por que eu entrei em silêncio e conversei com vocês pelo flipchart? Por que usei esse jeito para ensinar roteiro? O que vocês aprenderam?" (informação dada por Grazinoli, 2009)

Expondo a essência de tipo de pensamento abstrato necessário ao escritor cinematográfico, o educador criou um processo metonímico, em que, a partir de uma amostra do trabalho, os educandos despertavam sua habilidade para criar hipóteses, testar, errar e, principalmente, ter clareza para avaliar seu próprio desenvolvimento. Ainda, a partir da própria experimentação, estimulou a apropriação das características básicas de formatação de roteiros audiovisuais sem falar disso diretamente. A reflexão posterior ao exercício tem dois objetivos: identificar aprendizagens e, principalmente, evidenciar os objetivos e subtextos da situação criada, expondo o processo pedagógico.

Exercícios análogos são realizados em diferentes projetos. E são, frequentemente, sucedidos pela etapa de construção dos roteiros dos vídeos que serão filmados.

Diversas entidades de Perfil 1 propõem a realização de um roteiro coletivo, muitas vezes a partir de histórias propostas pelos próprios alunos na ficha de inscrição, ou de argumentos escritos a partir das atividades realizadas. Trata-se de prática absolutamente frequente em oficinas deste perfil, e a sequência de acontecimentos descrita por Barradas, abaixo, é praticamente idêntica ao meio pelo qual são realizados os roteiros das Oficinas Kinoforum e das Oficinas Tela Brasil:

Na sexta (depois das atividades de abertura), eles ficam com a missão de, na segunda-feira, trazer uma ideia, sem assinar: só um roteiro, um argumento. A gente nem explica direito. Não existe uma aula de roteiro dizendo o que é um argumento. A gente explica por alto. Aí, na segundafeira, que é aula de roteiro, [...] a gente começa lendo as propostas. E a gente vai categorizando as propostas no quadro: "essa proposta aqui é sobre a pessoa que vende comida na linha do trem; essa proposta aqui é sobre a história do bar da cidade, como essa cidade está relacionada..." A gente vai categorizando vários temas [...] e já começa a agrupá-los: “esse aqui é a mesma coisa daquele lá...” Depois a gente faz o processo de interrelacioná-los, até sobrar uma quantidade de temas que não dá para ser mais reagrupada. Dentre eles, a gente elege três temas, e vai discutindo, conversando. Depois, a gente pergunta: "você quer participar de qual filme?", e os mais votados são os filmes eleitos para serem produzidos. (Informação dada por Igor Barradas, 2009) 
Essa atividade é, em geral, conduzida pelo coordenador do projeto ou professor responsável pelas disciplinas de linguagem (Roteiro, Direção, Teorias da Edição). No final dessa atividade, em geral, o educador passa orientações gerais para elaboração e formatação das propostas de roteiro - sem grande apego às formas clássicas de redação de roteiro. Apresenta-se uma introdução a conceitos gerais de dramaturgia, geralmente tanto em ficções como em documentários.

5. Aula prático-teórica de Produção, ou jogo lúdico envolvendo práticas similares às de um produtor. Propõe-se, por exemplo, uma atividade em que os alunos devem produzir um evento, como uma festa de aniversário, e a partir da organização criada por eles para tal festa, demonstrar os diferentes tipos de pensamento envolvidos na atuação de um produtor. Em alguns casos, propõe-se, de início, que os alunos façam listas e busquem pensar em tudo o que seria necessário para a gravação dos vídeos que irão realizar. E a partir da organização proposta por eles, é que se apresentam as diferentes planilhas e formas clássicas de se organizar e produzir uma gravação.

É muito incomum, nesse perfil de oficinas, a realização de aulas teóricas sobre produção. A educadora Débora Garcia, do Projeto Geração Futura, relata uma aula que criou com esse tema:

[Tratava-se de] uma dinâmica de jogo em que os alunos experimentam um dia na vida de um produtor de Conteúdo do Futura. Simulamos situaçõesproblemas que precisam ser resolvidas pelos grupos, nas quais cada um "vira" editor-chefe de um programa de linha do Canal: Globo Ciência, "Passagem para", Ética, etc. "Pôr a mão na massa", ainda que de forma simulada, é um grande jeito de aprender com significado. (Débora Garcia, Questionário online, 2009)

Essa atividade é, em geral, ministrada pelo coordenador ou produtor da Oficina, ou por ex-aluno do projeto em processo de formação como educador.

6. Aula prático-teórica de câmera e som, ou jogo lúdico que envolva aspectos técnicos e de linguagem. Aula em geral, nos projetos deste perfil, ministrada por exalunos em processo de formação como educadores, e em que se cria um espaço privilegiado para a experimentação, por parte desses jovens aprendizes, de meios criativos para se ensinar. As aulas têm como característica principal a sequência 
prático-teórica: primeiramente, exercícios que visam despertar a curiosidade e sugerir questões, que conduzem naturalmente à reflexão mais teórica e às referências. Como no criativo exercício relatado por Leonardo Cubas Gusmão, ex-aluno da Escola Livre de Cinema e Vídeo de Santo André e educador das Oficinas Tela Brasil e Ouroboros:

\begin{abstract}
O exercício consistia em gravar uma cena, ou mesmo um "curtinha" editado na câmera (criado na hora ou retirado do roteiro de gravação dos curtas que iriam realizar) duas vezes: uma com imagem, e outra com a lente tampada. As dúvidas deveriam ser esclarecidas ao final do exercício, para que pudessem experimentar, e naquele momento, a própria demanda da aula começasse a surgir. Feito isso, juntamos todos, pedi que não desmontassem os equipamentos, que deixassem do jeito que utilizaram. Então assistimos aos resultados. Os próprios educandos geraram discussões sobre as impressões que o som causava antes de verem a imagem dos "curtas", e imaginavam coisas diferentes; essa discussão não estava prevista no meu roteiro, surgiu no momento, e foi muito rica. Então começamos a analisar as diferenças, dificuldades e limitações que gravar com som e sem som geravam; apontamos sugestões de resoluções de problemas quanto ao posicionamento do microfone (gravar sem a imagem era justamente para eles perceberem que, sem ela, poderiam chegar muito próximos com o microfone, e com ela, já havia o problema da invasão do boom no quadro) e mostrei macetes para manuseio do equipamento de forma otimizada, sempre tentando evitar os termos certo ou errado. (Leonardo Cubas Gusmão, Questionário com educadores, 2009)
\end{abstract}

Apesar do grande fascínio que a câmera exerce sobre os alunos, essa aula em geral não ocorre nos primeiros dias de oficina, mas, muitas vezes, em um momento no qual as equipes, já definidas, estão começando a preparar seus vídeos. Sendo assim, não é incomum que tais atividades acabem sendo ministradas apenas para os alunos realmente interessados em exercitar tais funções durante a gravação - o que se por um lado afasta o restante da equipe dos reais desafios envolvidos no trabalho da equipe técnica, por outro, permite um maior aprofundamento para os que participam da atividade.

7. Atendimentos de diferentes educadores, aos grupos, antes das gravações. Tais atendimentos são geralmente realizados em sistema de rodízio: os alunos organizamse nos grupos, normalmente 3 ou 4, com 5 a 7 alunos por grupo, e os professores os atendem individualmente, em sequência - em geral, um professor de linguagem, um de perfil mais técnico e outro mais dedicado à produção. Nos atendimentos busca-se auxiliar os alunos com eventuais ajustes de roteiro, pendências e dúvidas de produção, e o planejamento geral de linguagem. O papel dos educadores, nesses atendimentos, não é um direcionamento artístico ou temático, como comenta Frederico Cardoso, 
coordenador das Oficinas Cinemaneiro / Fora do Eixo / Boteco:

\begin{abstract}
A equipe do projeto não interfere de maneira nenhuma na criação daquela turma. [...] A única coisa que a equipe acaba fazendo, e que tem alguma interferência na realização, é muito mais de ordem prática. O sujeito pega um roteiro que tem trinta personagens, e são quarenta locações, com trinta minutos de duração, então não vai dar pra fazer. A gente tem aqui seis horas pra filmar, mais de doze horas pra editar o filme, três dias pra produzir, aí não vai dar pra fazer. Então é sempre de ordem prática o bloqueio a alguma ideia, não é pela ideia, é pela dificuldade e impossibilidade de executar aquela ideia minimamente. Então a gente acaba tendo um limite, não dá pra idealizar um filme que seja rodado na Praia de Ipanema. Não tem como numa oficina carregar todo mundo pra lá, fazer o filme e voltar. Então, o ambiente é o que nos limita, mas a temática é qualquer uma. (Depoimento dado por Cardoso a Souza, 2009)
\end{abstract}

8. Gravação, em geral, em uma ou duas diárias, em que são fornecidos equipamentos semi-profissionais básicos (câmeras digitais, microfones), e os alunos são acompanhados e supervisionados por um educador (era mais comum no início dos anos 2000) ou ex-aluno em processo de formação como educador (mais comum hoje em dia). A gravação, geralmente tem como limitação única ser realizada nos arredores da sede da oficina, como indicado por Cardoso e também por Viviane Ayres, cocoordenadora do Cinemaneiro:

Tem que ser algo em torno da oficina. Então ele já tem aquele ambiente montado, não tem como ele inventar um cenário (que pode sim, tem muita coisa que é você que inventa). Mas, sabendo o que ele tem que fazer e que ele vai fazer o seu filme por ali, ele já tem que pensar numa história que caiba naquele ambiente. (Informação dada por Viviane Ayres a Souza, 2009)

9. Edição, em geral em 1 ou 2 diárias, com a operação das máquinas via de regra sendo realizada por educadores ou ex-alunos em processo de formação, sob total orientação dos alunos. Os coordenadores e educadores, em geral, conceitualmente prefeririam que a operação fosse feita pelos alunos. Mas a curtíssima duração da oficina é um grande impeditivo para que os alunos se apropriem da linguagem e das ferramentas técnicas da ilha de edição, e possam editar com a fluência e velocidade necessárias para cumprir o prazo proposto para a oficina. Como destaca Josinaldo Medeiros, ex-aluno do Cinemaneiro, educador das Oficinas Humano-Mar e presidente da Cidadela:

$\mathrm{Na}$ edição se tem pouco tempo. A nossa vontade era que eles operassem o 
equipamento. Como o tempo é muito curto, e até a gente vive essa dificuldade, porque às vezes trava e não sai, fica aquela coisa difícil, porque tem muitas horas de material bruto... Mas a relação é totalmente democrática, e quem dá a palavra final são eles. A gente vai falando, sugerindo como pode ser montado o filme... E aí, uma coisa que eu gosto de fazer sempre, é que a gente entra na ilha pra brincar... (Informação dada por Josinaldo Medeiros, 2009, p. 13)

10. Exibição pública (em projeção ao ar livre ou na televisão), ou interna (em projeção aberta à comunidade ou exclusiva para os alunos) dos vídeos resultantes. Há ocorrências de projetos em que, nessa exibição, conta com a participação de um convidado, em geral um cineasta com um filme em lançamento. Muitas vezes, os vídeos dos alunos são exibidos em meio a trabalhos profissionais ou de outras entidades, como comenta Frederico Cardoso, coordenador pedagógico do Cinemaneiro: “A gente não faz uma sessão só com o filme daquela turma, a gente faz sessão com curtas-metragens brasileiros de qualquer lugar, alguns profissionais já, outros de outros cursos que acontecem por aí afora, como o Cinema Nosso." (Cardoso, 2009)

Para Zita Carvalhosa, produtora-executiva das Oficinas Kinoforum, é através das exibições, no final das Oficinas, que o público das localidades pode de fato ter um primeiro acesso a essa produção. Segundo ela, os objetivos do projeto não mudaram muito desde quando o projeto foi desenvolvido junto com Christian Saghaard: [referese ao projeto original] "no final de cada oficina, a gente faria uma exibição pública dos trabalhos dos alunos para aquele mesmo público, para que vissem um pouco o que estava acontecendo. A ideia das oficinas não mudou muito nesses quase 10 anos de existência”. (Informação dada por Zita Carvalhosa, 2009)

Para Marina Santonieri, coordenadora das Oficinas Tela Brasil e Oficinas Ouroboros, a exibição final torna-se, praticamente, um novo ponto de início, que gera a motivação necessária para que os alunos continuem a atuar na área:

Acredito que esse é o maior estímulo pra fazer pela primeira vez e pra continuar fazendo. Compartilhar é a motivação do produto audiovisual; sem público, não há história para ser contada. É extremamente importante que haja a exibição pública desses produtos, principalmente pela motivação e apropriação dessa via de expressão: se eu não me identifico com o que está na tela, nem realizo, nem assisto. (Informação dada por Marina Santonieri, 2009) 


\title{
Características Singulares deste Perfil
}

\section{Itinerância}

Muitos projetos deste perfil têm característica itinerante. Nestes, destaca-se especialmente a perspectiva de despertar a sensibilidade de novos espectadores críticos e potenciais produtores audiovisuais em locais com pouco acesso a cinemas e, menos ainda, a esse tipo de formação, permitindo, especialmente, que os alunos construam suas próprias imagens e pontos de vista sobre o espaço social em que vivem.

Como se percebe na descrição de objetivos de algumas dessas entidades:

\begin{abstract}
Através das oficinas, se pretende desvendar novos olhares, universos e concepções de imagem, oriundos de grupos sociais que habitam essas regiões, que ainda têm acesso limitado aos circuitos de produção e exibição audiovisual. [...] Caracteriza-se, assim, como um modelo de ação cultural, que produz cinema, revelando novos olhares e integrando o Festival em toda a cidade. (Oficinas Kinoforum, site do Projeto, grifo meu)

O Observatório Ambiental Humano Mar é um dispositivo de monitoramento popular das transformações socioambientais. O principal objetivo do Observatório é criar instrumentos de empoderamento das sociedades civis locais ao dar aos moradores condições de observar, regular e gerir o ambiente do qual fazem parte. [...] O Observatório se torna referência de espaço social de aprendizado e inclusão para as comunidades locais. (Humano-Mar, Questionário de Mapeamento, grifo meu)

O objetivo geral das Oficinas Itinerantes de Vídeo Tela Brasil é aproximar a linguagem audiovisual de jovens de baixa renda de diferentes comunidades e cidades do Brasil que, normalmente, não têm acesso a estes recursos. [...] O projeto oferece aos alunos a oportunidade contar suas próprias histórias através de imagens e sons e vê-las retratadas na tela do cinema para os espectadores. (Oficinas Tela Brasil, Questionário de Mapeamento, grifos meus)
\end{abstract}

Nestes projetos, as sedes tendem a ser mais dedicadas à administração e gestão pedagógica dos projetos (gestão financeira, reuniões, preparações de professores, etc.) e menos ligadas às atividades de formação. Por exemplo: As citadas Oficinas Kinoforum (SP) e as Oficinas Tela Brasil (SP) realizam em suas sedes apenas finalização dos vídeos produzidos nas oficinas: edição de som, masterização dos DVDs, etc. 
As Oficinas Kinoforum, entre 2001 e 2009 realizaram 50 oficinas em 48 diferentes comunidades do Estado de São Paulo. Sempre em parceria com uma organização local - OSCIP, entidade de bairro, igreja, escolas públicas, etc. -, as Oficinas já ocorreram nos mais diversos tipos de espaço: de salas de aula perfeitamente equipadas e iluminadas, a porões escuros e literalmente cinematográficos. Quando realiza uma parceria, além da exigência de que o local disponha de uma sala de aula grande para as atividades em grupo, e três salas distintas para o período de edição - o que nem sempre é possível arranjar -, se espera dos parceiros que:

\footnotetext{
já tenham um trabalho desenvolvido já há alguns anos na comunidade, importando o interesse em pelo menos iniciar uma aproximação com a área audiovisual. [...] O que me preocupa quando faço uma parceria, é que esse parceiro dê condições aos jovens que fazem a oficina de dar continuidade ao trabalho audiovisual. Isso não significa dinheiro, patrocínio, e sim organização, responsabilidade com esses jovens, e iniciativa para continuar a ação no local. (Saghaard apud Cota, p. 32)
}

O espaço das atividades varia de localidade para localidade, e isso tem implicações positivas. As atividades práticas audiovisuais, que tomam boa parte do tempo da oficina, são realizadas no entorno dos espaços físicos, e é nessa integração entre alunos e bairro que se constrói o "espaço social de aprendizagem”. Os espaços mais importantes acabam sendo também externos e de fronteira ao espaço físico do parceiro local.

\section{Viés profissionalizante}

\section{Realização de módulos de aperfeiçoamento, etc.}

Outra preocupação comum a iniciativas deste perfil é criar condições para a continuidade das atividades audiovisuais de seus alunos - em uma perspectiva laboral ou empreendedora. Ainda que os projetos não tenham intenções profissionalizantes, detectou-se que os alunos buscavam posições no mercado de trabalho mesmo a partir 
das curtíssimas - e de perfil não especializado - oficinas que realizavam. Como destaca a produtora das Oficinas Kinoforum Zita Carvalhosa:

\begin{abstract}
Nesses anos todos, outras demandas foram se acrescendo, quer dizer, a gente veio com um projeto, e trabalhando com pessoas; a gente vai incorporando as ideias dessas outras pessoas que estão trabalhando com a gente, então, surgiu o módulo 2, que era uma oficina um pouquinho mais direcionada para a parte técnica, sem nenhuma vocação de profissionalização, mas no sentido de ter a sensibilização e poder ter uma pequena formação que lhes permitirá entrar nesse ambiente audiovisual já com uma qualificação. (Informação dada por Zita Carvalhosa, 2009)
\end{abstract}

No caso das Oficinas Kinoforum, já em 2002 foi desenvolvido e implantado com sucesso o Módulo II - voltado a alunos formados no Módulo I e que queiram aprofundar seus aprendizados -, e que segue até hoje. Ele é sempre realizado no centro de São Paulo, estabelecendo um ponto de encontro e troca cultural entre alunos advindos de oficinas realizadas geralmente nos extremos das diferentes regiões da cidade.

A equipe das Oficinas Humano-Mar, também atenta a essa necessidade, desenvolveu um portal colaborativo (espaço virtual de troca) ${ }^{66}$ e realizou, em 2009, um grande encontro entre todos os ex-alunos, além da $2^{\text {a }}$ etapa de oficinas, realizadas nas mesmas cidades do primeiro ciclo, sobre temas como mídias digitais, produção cultural, pesquisa social e educação ambiental, e cineclubismo. Em 2010 serão realizadas as $3^{\mathrm{a}}$ e $4^{\mathrm{a}}$ etapas, com oficinas de roteiro e pesquisa, produção e fotografia, sem o objetivo específico de realizar filmes durante as oficinas, e sim incentivar os parceiros locais para que produzam sozinhos. E para que tais produções se desenvolvam, os educadores da entidade vão orientar os roteiros à distância, via internet. Segundo Barradas, "esse modelo de acompanhamento, de troca contínua, se tornou a espinha dorsal. Não dá para sair de um município e fechar o ciclo ali, e querer que os monitores (alunos) produzam resultados sozinhos. É uma respiração, um envolvimento. Não é um "deixa que eu faço" e nem um "se virem vocês aî" é um "vamos fazer juntos". (Informação dada por Igor Barradas, 2009)

Já as Oficinas Tela Brasil realizaram, em 2009, a primeira edição de seu módulo avançado. Os roteiros foram selecionados a partir de um concurso via internet

\footnotetext{
${ }^{66}$ Ver em: http://www.humanomar.com.br/principal.
} 
- e a oficina foi realizada com jovens que já tinham experiência prévia em audiovisual - com ex-alunos ou não de outras edições do projeto.

Não se trata, em nenhum dos casos citados, de uma tentativa de realizar uma abordagem profissionalizante - o que inclusive seria delicado, dado o perfil também curto das atividades propostas. Acredita-se que, com essas atividades complementares, o jovem possa vir a se expressar com a ferramenta. E, caso venha a ingressar no mundo do trabalho, que o faça minimamente melhor preparado.

\title{
Formando jovens educadores
}

Se em Oficinas de Perfil 1 não costuma existir uma intenção profissionalizante, diversos ex-alunos destas oficinas passam a atuar nos próprios projetos como monitores, aprendizes e assistentes de produção. É interessante destacar que diversos projetos, em dado momento, migraram da figura do monitor "aluno de universidade" para ex-alunos do projeto, valorizando o envolvimento e criatividade com que estes assumem o desafio. Como destaca Carvalhosa:

\begin{abstract}
Nesse tempo também, a gente percebeu que quando a gente começou as oficinas, a gente não tinha essa figura do monitor; quer dizer, o monitor era um estudante da USP que estava lá recebendo um valor simbólico para ajudar no projeto social. Com o passar dos anos, a gente viu que, na verdade, os nossos ex-alunos eram melhores monitores do que naquele ponto de partida. E era também um pequeno mercado de trabalho que se oferecia a esses monitores, a esses ex-alunos que, em certo sentido, tinham se destacado, tinham se interessado mais especificamente pelo trabalho. $\mathrm{O}$ fato de esses agentes serem monitores também lhes permitiu uma abertura para um espaço de trabalho no audiovisual como um todo, e para o qual alguns se encaminharam. (Informação dada por Zita Carvalhosa, 2009)
\end{abstract}

Um aspecto central do sucesso da mudança pedagógica que essa inserção dos monitores implica é sua estrutura, que sugere uma perspectiva de horizontalidade e de valorização de diferentes saberes, como vimos no Capítulo 4, item 4.1.

Josinaldo Medeiros, ex-aluno do Cinemaneiro que virou educador das Oficinas Humano-Mar, comenta: 
diferencial é esse, e foi isso também que me fez querer fazer cinema. [...] Porque a figura do professor é uma figura meio emblemática; parece que ele está em outra esfera, está acima. Mas quando você diz que ele é igual a você, que está no mesmo nível, que tanto o professor quanto o lixeiro estão no mesmo patamar...[...] A gente achou que deveria discutir essa questão... [...] As pessoas se complementam... (Informação dada por Josinaldo Medeiros, 2009)

Alunos que se tornam educadores, muitas vezes desenvolvem tal grau de autonomia, que criam projetos próprios, muitas vezes montando suas próprias organizações.

A gente nota que tem determinadas pessoas com uma vontade e uma tendência a fazer um trabalho técnico, fotografia, câmera, senso de câmera, edição, som e tal. Então, essas pessoas que descambam um pouco mais para o lado técnico, normalmente são pessoas que não têm tanta paciência para ficar em um computador elaborando um projeto, captando recursos; não são empreendedores por natureza, vamos dizer assim. Então, a gente procura direcionar essas pessoas para oportunidades de estágio, trabalhos que aparecem, que a gente cava e acaba conseguindo, não na medida em que a gente gostaria, mas que acaba conseguindo, de certa forma. Outra vertente são os empreendedores, são as pessoas que claramente querem fazer os seus projetos, querem dirigir filme, querem fazer alguma mostra de cinema, que têm algum tipo de recorte que consideram importante. [...] Quem quer fazer qualquer projeto acontecer, encaminha a sua ideia, esteja em que nível estiver, pode ser só uma ideia e uma linha, ou já um préprojeto, que a gente orienta pra que ele seja bem construído. E tem um grupo também que capta recursos aqui; esse projeto é encaminhado a esse grupo. (Informação dada por Cardoso a Souza, 2009)

As entidades de origem cumprem um importante papel nesse passo, oferecendo suporte para que os alunos desenvolvam projetos dentro do seu espaço social. Como comenta Cardoso:

Acima de tudo, aqui é um ponto de convergência social e cultural. As pessoas montam suas equipes aqui, montam seus projetos, implementam seus projetos, captam recursos. Tem umas 30 pessoas dessas 700 , mais ou menos, que passaram pelas oficinas que, hoje em dia, acho que a gente pode considerar como uma equipe de trabalho, que está aqui trabalhando para a sua própria existência profissional e pessoal. E se cada um fizer um projeto, todo mundo vai ter trabalho o ano todo; a idéia é essa. [...] Eu tenho uma produtora com a Viviane, [...] mas havia a necessidade de ter uma personalidade jurídica dedicada às produções dos ex-alunos. Então, a gente montou uma OSCIP que se chama Cidadela [...], e é hoje a organização que abriga os projetos todos que saem do Cinemaneiro. E tem projetos que são meus também, tem projetos que são da Viviane, projetos que são dos ex-alunos, e assim como tem projetos que a gente acaba encaminhando pela produtora, que trabalha sempre com produção. Aqui é um ambiente de trabalho que abriga todo mundo que fez oficina com a gente, e que está interessado em continuar trabalhando com isso. Então, tem algumas pessoas que já estão inseridas no mercado de trabalho, e não trabalham só em projetos nossos, mas em outros projetos por aí afora. Tem algumas pessoas que vêm trabalhando há algum tempo conosco aqui, 
recebendo cachê e tal, tem outras pessoas que simplesmente vêm fazer os cursos, e tem sempre algum projeto acontecendo, seja um projeto sem dinheiro nenhum, sem patrocínio nenhum, ou algum outro com patrocínio (Informação dada por Cardoso a Souza, 2009)

Medeiros, que hoje é presidente da Cidadela, percebia no esforço um aceno em um sentido, muito benvindo, do desenvolvimento da autonomia dos ex-alunos, da atuação conjunta e, de certa forma, de coautoria:

[o surgimento da Cidadalela] foi muito também da necessidade de estar produzindo; tudo nasceu da necessidade. A primeira etapa foi de experimentos, de experimentar. A segunda foi o núcleo de produção Cinemaneiro: a "galera" começou a se profissionalizar. Aí a gente começou a escrever mesmo, a fazer. Sempre com a orientação do Frederico, a gente criou um ponto de apoio a projetos em que se mandava a ideia e, a partir daí, com sugestões do Frederico, da Viviane, a gente ia estruturando o projeto. A gente começou a pensar "tem tanta gente aqui, interessada em produzir, e a gente tem que ficar pegando CNPJ emprestado de outra ONG... Vamos fazer uma para a gente..." Aí a gente fez, e está dando certo até agora... A gente ainda está com o Cinemaneiro acontecendo, desde 2002... A Cidadela, criada em 2005, está fazendo o Cinema Para Todos agora, que é um projeto de exibição para escolas. E já tem mais de 70 filmes, só lá dentro, da "galera" do Cinemaneiro... E participamos de um processo de formação muito informal, mas que deu muito certo. Não é informal; acho que foi mesmo simbiose, fusão, porque foi a fome com a vontade de comer (risos) (Informação dada por Josinaldo Medeiros, 2009)

Se no Perfil 1 a questão do desenvolvimento da autonomia e da autoria dos exalunos já aparece com algum destaque, é de fato a partir do Perfil 2 que essa perspectiva aumenta muito - com o acréscimo de carga-horária e duração, e também com as novas ferramentas que passam a ser utilizadas.

\subsubsection{PROJETOS DE PERFIL 2 - CICLO INTERMEDIÁRIO E CARGA- HORÁRIA DE BAIXA A INTERMEDIÁRIA (MÁXIMO DE 400H/AULA)}

Duração intermediária: 90 a 360 dias

Carga horária: 20 a 400h/aula

Total: 40 projetos $(57,14 \%$ do total $)$

Aldeia - Agência de Desenvolvimento Cultural, Educomunicação, Infoinclusão e Audiovisual: Aldeia Digital e Escola de Mídia (CE)

Anthares Multimeios: Oficina de Vídeo da Anthares (SP) 
Associação Amigos das Oficinas Culturais do Estado de São Paulo: Projeto Talentos Especiais - Oficina de Cinema para Deficientes Físicos e Mentais (SP)

Associação Civil Favela é isso aí: Oficinas Favela e isso aí (MG)

Associação Cultural Projeto Perifa: Oficina de Cinema 16mm (SP)

Associação Imagem Comunitária (AIC): Rede Jovem de Cidadania (RJC) (MG)

Associação Novolhar: Novolhar na TV e Audiovisual na Fundação Casa (SP)

Bem TV: Olho Vivo (RJ)

Cabra Quente Filmes: Oficina de Audiovisual para a Nação Xukuru Ororuba (PE)

Casa da Árvore Projetos Sociais: Telinha de Cinema (TO)

Centro de Estudos e Ações Solidárias da Maré: PTCA Projeto Trabalho, Comunicação e Arte (RJ)

Cineclube Consciência: Oficina de básica Criação Audiovisual (SP)

Cineduc - Cinema e Educação:(RJ)

Coletivo Anti Cinema: Mídias (Sub) Urbanas (RJ)

Escola Audiovisual Cinema Nosso (Integralmente dedicada à EAP) (RJ)

Fundação Municipal de Cultura de Belo Horizonte / Programa BH Cidadania (BH) Cidadania (MG)

Grupo Ecológico e Cultural Tio PAC: TVCT/TV Cidade Tiradentes (SP)

IDEIA - Instituto de Desenvolvimento, Estudo e Integração pela Animação: Anima Escola (RJ)

Instituto Acaia: Além da Vaca - Turma de Vídeo do Acaia (SP)

Instituto de Arte e Cultura Garatuja: Oficina de Animação (SP)

Instituto Magneto Cultural: Nas Asas Vídeo Ação (SP)

Instituto Nacional de Educação de Surdos: CINES (RJ)

Instituto Nômades: TANKALÈ - Formação para o auto registro audiovisual quilombola (PE)

Jardim Miriam Arte Clube - JAMAC: JAMAC Cinema Digital (SP)

Luz, Câmera, Ação e Esperança na Vida: Luz, Câmera, Ação e Esperança na Vida $(\mathrm{RJ})$

Nossa Tela: Nossa Tela: exibições e produções de vídeos nas escolas (SP)

Núcleo de Arte Grécia: Oficina de Vídeo (RJ)

Núcleo de produção Arroz Feijão Cinema e Vídeo: Rolê na Quebrada (SP)

Oficina de Imagens - Comunicação e Educação: Ocupar Espaços (MG)

ONG Verde Cidadania: Projeto Casa Escola - Programa de Comunicação (RJ)

PAC_Pro-Apoio Comunitário: "Viajando na Telinha" (RJ) 
Ponto de Cultura “Alice, prepara o gato!” (RJ)

Programa Habitar Brasil - BID - Prefeitura Municipal de Belo Horizonte:

Iniciação ao Vídeo (MG)

Projeto Cine Escola, Associação Bominfa: Projeto Cine Escola (BA)

Projeto Graffiti com Pipoca: Projeto Graffiti com Pipoca (SP)

Projeto Olho Vivo: Minha Vila Filmo Eu (PR)

SESC Carmo: Curumim na Fita (SP)

TV Morrinho (RJ)

UEVOM - União Esportiva Vila Olímpica da Maré: Oficina de Cinema e Vídeo e Oficina de Televisão (RJ)

UNAS - União de Núcleos Associações e Sociedades de Moradores de Heliópolis e São João Clímaco: Projeto Produtora Escola de Áudio e Vídeo de Heliópolis (SP)

\section{Características gerais}

Neste perfil, se estabelecem com mais frequência dois tipos de estratégia:

a) Objetivo concreto, promovido a partir de etapas planejadas. Como ocorre nas oficinas curtas-intensas, a realização final de um vídeo pauta o cronograma e conteúdo das aulas, que são organizadas em algum tipo de sequência lógica visando à melhor realização dos vídeos. (Para esse caso, ver detalhes no perfil anterior, supondo um maior espaçamento entre as atividades. A sequência, nesses casos, é muito semelhante. Apenas quando for extremamente relevante, apontaremos para características destes casos excepcionais - projetos de Perfil 2 com estratégias mais semelhantes aos de Perfil 1);

b) Sequência didática envolvendo atividades e objetivos diversos (cadeia planejada de atividades, mas com múltiplas possibilidades de caminho), em que, para dar conta também especialmente de aprendizados não técnicos, arrisca-se a criação de aulas, jogos e dispositivos didáticos mais complexos, muitas vezes originais e mais sujeitos ao fracasso, mas que ambicionam corresponder, simultaneamente, a questões técnicas e intelectuais, além de 
emocionais e sociais. Esta será a estratégia descrita e analisada aqui, uma vez que as principais características da estratégia descrita acima já foi amplamente apresentada no último Subcapítulo.

As aulas são, nesta estratégia, em geral, mais curtas (1h30 a 3h) que no perfil anterior, e ocorrem de maneira sistemática e esparsa (por exemplo, 2 ou 3 vezes por semana), ou em períodos mais longos (4h a $5 \mathrm{~h}$ ), nos finais de semana.

Nos projetos de Perfil 2 é cada vez mais frequente a estratégia de se pulverizar a realização em pequenos e curtos exercícios ao longo do processo, diminuindo a importância e expectativa com o tal produto final. Como comenta Miriam Machado, coordenadora sócio-pedagógica do Cinema Nosso:

\begin{abstract}
A gente está tirando essa produção lá do final, fazendo com que ela esteja presente em todo esse processo, tirando o peso de uma grande produção [...] porque isso é dividido durante todo o processo de aula, e a gente tem tido bons resultados com isso [...] a gente sempre deixa muito claro que não tem nenhuma pretensão de mercado, até porque mercado de audiovisual inexiste no Brasil. [...] a gente quis tirar um pouco desse peso de uma produção final. A gente tinha um curso que durava 7, 8 meses e, ao final essa turma, fazia um filme, que aí acabava tendo um peso muito grande, porque tinha que ser "o filme da minha vida". (Informação dada por Miriam Machado a Gustavo Souza)
\end{abstract}

Dos 40 projetos deste perfil, apenas cinco projetos possuem intuito profissionalizante, e dois são voltados ao empreendedorismo. O objetivo mais comum, dentre estes projetos, é a sensibilização audiovisual. E caso o aluno realmente se interesse pelo tema, poderá retornar e dar continuidade, por exemplo, a partir de um curso avançado, como é o caso do Cinema Nosso:

\footnotetext{
Num primeiro momento, em que esse aluno está conhecendo o que é o audiovisual, está querendo entender como ele pode utilizar de alguma forma aquilo na sua vida, no seu cotidiano, a gente tem um curso básico com uma duração de três meses. Duas vezes por semana, seis horas semanais. Se ele tiver interesse, a gente tem um curso avançado de quatro meses. Nesse curso de quatro meses, ele estará realmente entrando mais a fundo na história, na parte técnica e tudo isso, tanto em cinema quanto em animação. Então, durante um ano esse aluno teve uma introdução, e depois passou para um estágio, e está entendendo melhor aquela linguagem que ele escolheu. (Informação dada por Miriam Machado, 2009)
}

Os projetos deste perfil, em geral, não propõem, em seus módulos iniciais, 
nenhum tipo de especialização técnica, ou seja, como nas oficinas de Perfil 1, os alunos podem circular entre as diferentes áreas. Sendo que neste Perfil 2, isso é ainda mais concreto, dado que muitas vezes há mais de um ciclo de produções, e os alunos podem experimentar diferentes funções ao longo do curso. E, de maneira geral, não há ainda uma organização em torno de funções técnicas: “A construção processual dos trabalhos, de decisão... isso fica representado nos créditos: a gente não fragmenta (tal fez isso ou aquilo), tudo fica assinado coletivo". (Ibidem)

Uma oficina imaginária de Perfil 2, organizada em uma sequência didática envolvendo atividades e objetivos diversos, preveria um circuito de ferramentas dentre as citadas abaixo, sem ordem fixa e sugerindo múltiplos caminhos:

a) atividades especiais e lúdicas de perfis diversos, envolvendo a prática audiovisual, mas colocando em primeiro plano a integração, o diálogo, a cooperação e, especialmente, a curiosidade dos alunos.

Hélio Passos, coordenador do BH Cidadania, sugere um exercício de estranhamento, de certo "olhar antropológico":

\begin{abstract}
Vamos supor que você comece com um exercício do olhar; pode ser um exercício de fotografia ou um exercício de anotação - uma fotografia escrita, simples assim. E pede para os alunos começarem a observar, treinar aquele olhar, e relacionar isso com o olhar antropológico, mostrando para eles que, nesse momento, eles não são parte. que eles podem não ser parte daquilo. Eles são parte, claro, mas eles vão fazer esse exercício de observar: "aquela coisa acontece assim, mas ela acontece por um motivo", ou "a coisa é assim e a forma dela é assim". E aí começa a explorar isso de passar a refletir, a experenciar tudo que está ao seu redor, mas que você não está notando. (Informação dada por Hélio Passos, 2009)
\end{abstract}

b) detecta-se também a emergência de jogos lúdicos envolvendo gravação de imagens - ou primeiro contato com a câmera, ministrado por professor de perfil mais "lúdico", carismático, ou ex-aluno do projeto em formação como educador.

Tais jogos, em geral, envolvem mecanismos criados para estimular e provocar os alunos na aproximação aos temas e técnicas da prática audiovisual. E são 
realizados logo nas primeiras aulas, como comenta o aluno Diogo Felipe, do Cinema

Nosso: "Eu também faço um curso técnico de câmera. E a gente não tinha contato com a câmera! Então, quando a gente chegou aqui, lá pra $3^{\mathrm{a}}, 4^{\mathrm{a}}$ aula... 'Vamos gravar!" (Informação dada pelos alunos de Diogo Felipe, aluno do Cinema Nosso, 2009)

Como se vê, nas duas práticas citadas pela equipe da Oficina de Imagens, que envolvem os alunos em jogos lúdicos, o primeiro faz isso a partir de um mecanismo óptico:

Em todos os projetos, a gente tem um percurso metodológico, a gente começa produzindo nas câmaras escuras: "vocês conhecem câmara escura de papelão, zoom?". Exatamente para que as pessoas comecem entender a formação, o princípio da formação da imagem. E a gente faz uma analogia também: assim como a imagem está invertida na caixa, assim como ela esta invertida no zoom, é como as coisas acabam sendo de certa forma invertidas na sociedade também (Informação dada por Paula Kimo, 2009)

E também a partir de um jogo simples, com regras próprias, e que torna a experimentação com a ferramenta algo lúdico e minimamente direcionado - evitando os "brancos criativos" que podem ocorrer quando se pega a câmera de vídeo pela primeira vez -, ao mesmo tempo em que se estimula o convívio e a integração:

\begin{abstract}
Primeiro, a gente dá o equipamento para as pessoas produzirem - um produto não assistido. Não "assistido" no sentido de que a gente não ajuda, a gente entrega o equipamento, ensina a filmar e depois a gente vai assistir o resultado, e é um exercício que, na verdade, não funciona só para o audiovisual, com interesses audiovisuais, mas para a gente conhecer a turma. É um exercício que a gente deu o nome de Conta Vida, em que cada pessoa tem 30 segundos para contar a sua história até aquele momento, e depois mais 30 segundos para contar a partir daquele momento até o fim... [...] é um exercício importante para a gente porque ajuda a alinhar, a saber de onde essas pessoas estão vindo. (Ibidem)
\end{abstract}

Há uma visível preocupação em pulverizar as gravações ao longo do processo, “desglamourizando-as", e oferecendo estímulos para que a experimentação tenha parâmetros, e os alunos, suporte. Como comenta Aléxia Melo, gerente de projetos da Rede Jovem de Cidadania / AIC:

Como deslocar ele daquilo que já conhece para conseguir pensar aquilo que ele pensa de uma maneira diferente? [...] Então, a gente fez uma analogia de elementos de linguagem com narrativa e algumas coisas de tempo, do ritmo. Os elementos de linguagem eram: cores misturadas com narrativas, que davam em uma terceira coisa que a gente não sabia o que 
era. Então, eles foram construindo os vídeos que estão nesse processo, um processo formativo de um mês (dentro do ciclo maior), que era muito rápido, e eles tinham que produzir vídeos de cinco minutos. E a gente não queria que caísse só para o documentário. A gente queria que tivesse uma provisão de linguagens mesmo. Então, cada grupo intuitivamente escolhia uma cor, que correspondia a um elemento de linguagem, e ia trabalhar esses elementos de linguagem na narrativa. E o vídeo dele era construído a partir disso. Então, a própria experiência do jogo e o processo do produto estavam bem juntos. E tem de tudo! Tem clip, tem ficção, tem de tudo. (Informação dada por Aléxia Melo, 2009)

c) dispositivos pedagógicos voltados à criação - ou primeiro contato com a linguagem audiovisual. Evita-se ao máximo o uso do recurso da aula expositiva-teórica, que remete ao modelo de ensino de roteiro nas universidades. Muitas vezes, o assunto da aula sequer é audiovisual. Por exemplo, pode ser um exercício de criação de pequenas histórias a serem transformadas em história em quadrinhos - com o objetivo de provocar e estimular a construção, por parte do aluno, do conceito de ponto de vista, a partir do qual é possível se esboçar uma visão crítica sobre seu próprio espaço social.

Valdo Siqueira, coordenador da Aldeia (CE), comenta a interpenetração entre criação e espaço social: "Muitos roteiros dos adolescentes da Aldeia são meras reflexões sobre seu lugar, uma rua do bairro, uma festa, alguém que merece atenção, a tarde, os conflitos sociais etc. Essa polissemia é valorizada, o que aumenta as chances de se reconhecerem como narradores audiovisuais". (Informação dada por Valdo Siqueira, 2009)

Para Mauro Reis Correa, co-coordenador do "Alice, prepara o gato!" 67, a criação é fundamental, e propicia um ambiente privilegiado, mas também muito intenso emocionalmente, sendo necessário jogo de cintura e bom-senso:

É a parte que damos mais importância. A criatividade. Mas, para a gente, criatividade não é a busca desabalada e até histérica sobre a originalidade. Entenda-se aqui o original como aquilo que nunca foi feito. A criatividade da redescoberta e ressignificação nos é mais cara. Fazer com que os demônios internos de cada um sejam exorcizados audiovisualmente, e que outros demônios sejam incorporados também no processo. Isso é

\footnotetext{
${ }^{67}$ Importante destacar que o projeto "Alice, prepara o gato!" trabalha com um público-alvo bastante específico: usuários do serviço CAPS - Centro de Atenção Psicossocial, com problemas de dependência com álcool e drogas. No entanto, como seus coordenadores fazem questão de destacar, não se trata de uma oficina terapêutica.
} 
angustiante. Por isto, em todas nossas aulas, a gente dá um jeito de propor exercícios-brincadeiras. (Informação dada por Mauro Correa, 2009)

A necessidade desse exercício constante da criação também inspira o surgimento de espaços sistemáticos - curso ou oficina especial para esse fim - sem, contudo, que se trate de uma oficina de roteiro. Como relata Machado:

[No Cinema Nosso] A gente também trabalha com a oficina da palavra, que é uma oficina em que se trabalha um pouco a narrativa, a construção de histórias. E que fatalmente vai auxiliar na construção de um roteiro, na expressão de uma ideia [...] A gente trabalha uma construção de roteiro, de argumentação, em que os alunos definem o que eles vão querer nesses exercícios: "Eu quero falar disso. Então vou produzir uma argumentação ou criar um grupo de roteiro e, a partir daí, defender essa minha ideia". Essas ideias, em sua grande maioria, vinham com isso. (Informação dada a Miriam Machado, 2009)

d) jogos de Produção, envolvendo práticas ou conceitos similares aos envolvidos com o dia-a-dia de um produtor.

A AIC desenvolveu uma estratégia extremamente original para construir, juntamente com os alunos, os conceitos necessários à compreensão das diferentes etapas de produção. A atividade tem como objetivo auxiliar os alunos a reconstruir, com suas palavras, e interiorizar os principais conceitos/processos da realização audiovisual. Para isso, a equipe criou um roteiro em que se estabelece uma série de metáforas que, com muito bom humor, desperta a curiosidade dos alunos e exige deles um esforço interpretativo-criativo altamente desafiador.

O processo é chamado "Como fazer omelete sem quebrar os ovos?", como comenta Aléxia Melo, gerente de projetos da AIC:

Eles nem entediam direito o que era essa etapa de produção. Eles sabiam produzir, mas ele não sabiam pensar a etapa de produção, as etapas da produção. Para a gente, não interessa: tem que saber pensar. Então a gente dividiu em quatro etapas. A primeira etapa é a fritação (risos), e aí a gente colocou assim: "Como fazer omelete sem quebrar os ovos?" Nessa etapa, a gente foi conversando muito com os meninos e vendo o que eles achavam dela. Esse nome também saiu disso, do momento de se ter a ideia. Então "olha-se nos olhos" do tema, do assunto. Inventam-se maneiras de abordar e de tratar o tema; inventam-se proposições, jogos namoros, ou seja, escolhe-se uma linha de atuação dentre as milhares de linhas possíveis, e essa é a fase de "fritação". Aí tem a fase de gravação: depois de "fritar", vai lá gravar. O que eles tinham que fazer: observar, registrar sons e visões, tal como no início dos tempos, quando as pessoas tinham visões e ouviam vozes. Então, e isso a gente também leva em conta, deu 
até arrepio. A gente conta também com esse lado sensível. Porque não adianta estar olhando para o visor ali enquanto algo está acontecendo algo aqui do meu lado. (Informação dada por Aléxia Melo, 2009)

e) gravações semi-profissionais, muitas vezes na fase final de curso, para as quais são fornecidos equipamentos semi-profissionais básicos (câmeras digitais, microfones), e os alunos são acompanhados e supervisionados por um educador (era mais comum no início dos anos 2000) ou ex-aluno em processo de formação como educador (mais comum hoje em dia).

Os limites de intervenção dos educadores, nas gravações, são extremamente variados. No entanto, há certo consenso em torno de dois parâmetros: questionar as escolhas dos alunos, confrontando-os constantemente com seus objetivos originais; e não omitir opiniões, o que resulta, em suma, em uma espécie de fronteira tênue, em que prevalece o bom-senso. Como comenta Roberto Robalinho, co-coordenador do “Alice, prepara o gato!":

$\mathrm{Na}$ hora de construir narrativas junto com eles, exige-se uma atenção muito grande. E a gente tem que ter cuidado de tentar não influenciar. Apesar de que isso é quase impossível esteticamente. Queremos que os alunos busquem as referências e que eles construam o olhar deles; a gente não direciona esse olhar: "Melhor você fazer um close aqui, vai ficar mais bonito, vai ficar mais interessante". Queremos que ele escolha e saiba defender a escolha dele também. Então perguntamos: "Por que você está fazendo um close aqui?" E ele vai dizer: "Por isso ou por aquilo!". Eu posso até questionar: "Mas você acha que tem sentido isso?" A gente influencia sim, mas o importante é que eles saibam o que estão fazendo. (Informação dada por Roberto Robalinho em 16 de março de 2009, p. 14)

f) edição, pulverizada ao longo do semestre e específica para os produtos finais, quando é o caso. A operação das máquinas é, em geral, ainda realizada por educadores ou ex-alunos em processo de formação, sob total orientação dos alunos. Mas há ocorrências, neste perfil, de operação das ilhas de edição pelos alunos.

É interessante como o educador Fernando Rebelo, da Oficina de Imagens, problematiza a questão da intervenção de maneira análoga a Robalinho com relação à gravação, devolvendo as questões para os alunos:

Se me perguntam o que eu acho, eu falo que não sei. Às vezes depende do quê: por exemplo, "ah, você acha que isso aqui fica legal no início ou no 
final?" Eu digo: "você já tentou colocar nos dois lugares para ver? Coloca no início e depois coloca no final, aí você vê se é bacana ou não". Ou: "Fernando, você não acha que está feio?". "Está feio, mas o que você quer com ela também? Não é porque está feio que você não vai usar; às vezes se usa a imagem feia para produzir algo..." É mais nessa questão, do que falar se está certo ou errado. (Informação dada por Fernando Rabelo, 2009)

g) exibições. Neste perfil, se detecta a emergência de diferentes formas de promoção de exibições - muito semelhantes entre si, mas com diferenças significativas.

(i) exibições iniciais, logo nos primeiros dias de curso, ao molde e como amplamente destacado no Perfil 1.

(ii) exibições sistemáticas, promovidas pela própria entidade (e muitas vezes fora dos horários das aulas) de curtas ou longas-metragens brasileiros, possivelmente até vídeos feitos em outras oficinas - do próprio projeto ou outros similares -, ou realização de atividade análoga, voltada para despertar a sensibilidade dos alunos, sob o ponto de vista do repertório.

Há projetos que promovem a ida dos alunos ao cinema, mostras e festivais. Há os que recebem, na sede da entidade ou do projeto parceiro, cineastas que estão lançando seus filmes, além de exibições de mostras e festivais. E há outros que promovem exibições públicas (em projeção ao ar livre ou na televisão), ou internas (em projeção aberta à comunidade ou exclusiva para os alunos) dos vídeos resultantes. Em modelo muito semelhante ao Perfil 1.

Detecta-se também a emergência de cineclubes geridos por alunos e ex-alunos, caso do Orkontrocine ${ }^{68}$, cineclube promovido pelos alunos do Cinema Nosso a partir de escolha realizada pelos alunos na página da entidade no site de relacionamentos Orkut - em geral a partir de lista contendo filmes brasileiros.

\section{Características singulares deste perfil}

\footnotetext{
${ }^{68}$ Comunidade do Orkontrocine no Orkut: $\underline{\text { http://www.orkut.com.br/Main\#Community?cmm=53644808. }}$.
} 


\section{Desenvolvimento pessoal}

Como vimos, nos projetos de perfil curto, o desenvolvimento pessoal dos alunos é consequência de um processo, sem, contudo, que haja atividades especialmente voltadas para esse fim. Então, se nos projetos de Perfil 1 o processo ocorria naturalmente (com alguma atenção das equipes), nos projetos de Perfil 2 já se detecta $^{69}$ a necessidade de criação de situações voltadas à integração entre os alunos e a um desenvolvimento mais pronunciado de aspectos de seu desenvolvimento pessoal.

Nesse sentido, o caráter coletivo da realização audiovisual é utilizado como recurso para auxiliar os alunos a desenvolver suas capacidades de diálogo e seu senso crítico: busca-se, muitas vezes, estimular que os alunos aprendam a distinguir "o que são" "do que pensam ou produzem", de modo que possam criticar algo sem criticar o outro, e analogamente, ouvir críticas às suas idéias e realizações sem senti-las como críticas a si e a sua personalidade.

Hélio Passos, do BH Cidadania, também aborda a questão central do diálogo nesse processo:

\footnotetext{
No projeto BH Cidadania, [...] tentamos mostrar para eles por que é interessante estar em grupo, por que é interessante respeitar o outro. É importante aprender a ouvir o outro, mesmo que ele esteja dizendo algo que não considera importante... (Informação dada por Hélio Passos, 2009)
}

Um trabalho em grupo, por princípio, não garante que tais habilidades sejam desenvolvidas. A construção desse espaço coletivo e colaborativo exige um esforço por parte dos profissionais das entidades, na medida necessária e viável a um curso de Perfil 2. Machado, do Cinema Nosso, reafirma essa hipótese, retomando a ideia de que, com o foco no processo coletivo, é possível obter ganhos mais pronunciados no processo do que no resultado ${ }^{70}$ :

\footnotetext{
${ }^{69}$ Esse aspecto é muito pronunciado nos projetos de perfil longo.

70 A problematização entre processo e resultado é um longo debate dentro do campo, desde os primeiros Seminários da Formação do Olhar, em 2002.
} 
As oficinas, o coletivo, é a máxima do grupo. Então todas as atividades são feitas de forma coletiva: o roteiro é de todo mundo, a ideia pode ter sido sua, mas, a partir do momento que você deu ela ao grupo, todo mundo tem o direito de mexer, ela já não é mais só sua. Esses são os simples princípios de todas ou quaisquer atividades que a gente faz. A gente vem valorizando muito mais o processo do que o resultado. (Informação dada por Miriam Machado, 2009)

A participação em um grupo, e a superação dos desafios constantes que tal situação exige, estimularia a maturidade de cada aluno:

O início das oficinas é com meninos jovens, jovens que são novos, e eles nunca fizeram oficina desse tipo, eles estão se conhecendo, cada um vem de um canto [...] No final de seis meses, aqueles que continuam - porque muitos vão saindo, por vários motivos - tem uma relação super interessante, próxima, e se vê que conseguiram ter uma experiência, que os levamos a entender um pouco mais essa coisa de viver em grupo, de trabalhar em grupo, da responsabilidade que isso implica, que cada um faz parte do grupo e que, para o grupo estar certo, cada um tem que dar. (Informação dada por Hélio Passos, 2009)

O desenvolvimento dessa maturidade, que se dá tanto no âmbito emocional como em aspectos sociais e intelectuais, implicaria, por fim, em uma maior capacidade de articulação, de circulação em diferentes ambientes - e se possível, em desejo:

Acho que a primeira preocupação é ampliar a capacidade da pessoa de fazer redes, de articular. [...]. Estamos nesse "mundão", e cada um vai achando o que tem que fazer, se tem isso de se articular com qualquer coisa, você se vira. Então se cria possibilidades para atuar, e isso eu acho que uma das coisas mais importantes, e a outra coisa é o desejo. Tentar falar para uma pessoa que não tem "tesão" nenhum que ela tem que te, é uma coisa difícil. Acho que isso a gente tenta passar com a vontade de fazer a coisa, de se divertir fazendo a coisa, de trazer o negócio para a sua vida com uma força tamanha (Informação dada por Aléxia Melo, 2009)

O Cinema Nosso tinha, até 2007, uma atividade chamada Oficina Cultural, que tinha, em alguma medida, o objetivo de auxiliar os alunos na construção de seus projetos audiovisuais e estimular seu desejo pelo próprio processo de aprendizagem, a partir de debates: "Era um momento de bastante dinâmica, de autoconhecimento, de construção de identidade dos alunos com a instituição. E a gente acabava tendo que mediar com aquele perfil de 'aluno cinema', que acha que qualquer momento em que não se está com a câmera é sacal...”. (Informação dada por Miriam Machado, 2009)

No Cinema Nosso, como em outros projetos deste perfil, os cursos são muitas vezes integralmente ministrados pelos mesmos educadores ao longo de todo o 
processo. Isso implica em os educadores terem que lidar, e superar os desafios da formação técnica com os de âmbito pessoal e interpessoal dos alunos. Atenta a essa espécie de sobrecarga que sofriam os educadores, a equipe do "Cinema Nosso" mudou de estratégia e contratou um profissional para auxiliá-los (obtendo, como veremos adiante, resultados que apontam para uma solução compartilhada com os projetos de Perfil 3):

Então a oficina cultural deixou de ser uma oficina: fragmentamos alguns conhecimentos e os professores ficam juntos, constroem a aula em conjunto. Foi muito "bacana" então... Num primeiro momento para a construção da identidade com a instituição, para que eles se conheçam, e até mesmo em respeito a esse educador. Enfim, não tem que ter mil e uma utilidades [...] Neste ano, em um primeiro momento, tivemos então uma pessoa que também era de Serviço Social (mas isso não era definidor) que trabalhou junto com o educador, que é o da técnica, e o da construção da "identidade" da turma, para que eles se conhecessem, para que se definissem as regras do jogo daquela turma - o que podia e o que não podia junto com eles. Foi muito "bacana" ouvir o educador, o da técnica mesmo, dizer "eu já dou uma aula diferente". (Informação dada por Miriam Machado, 2009)

\section{Viés profissionalizante / empreendedorismo}

Apenas cinco projetos deste perfil possuem intuito profissionalizante, e dois são voltados ao empreendedorismo (ou seja, de um total de 40 entidades de Perfil 2 , apenas $17,5 \%$ têm esses objetivos). E de maneira geral, o discurso das entidades deste perfil dá respaldo a essa informação.

No entanto, percebe-se que mesmo nos projetos que não têm como objetivo a inserção laboral, muitos alunos se desenvolvem de maneira tão decisiva, que o processo acaba implicando em uma melhor perspectiva de inserção profissional, e até mesmo em áreas além da audiovisual. Como comenta o coordenador da Aldeia, Valdo Siqueira:

No caso da Aldeia, a profissionalização não é um objetivo. Não há nenhum plano de que encaminhemos alunos ao mercado. Na realidade, trabalhamos na contramão dele. Mas é evidente que o aluno que é instigado a pensar e a ler para se manifestar por imagens, acaba se tornando alguém "diferenciado", porque o que normalmente se vê é que eles passam a ter mais confiança em si mesmos, buscam saltos maiores, saem da acomodação e do lugar em que eram vistos verticalmente, de cima para baixo - como em plongée na câmera. (Informação dada por Valdo Siqueira, 2009) 
Ana Paula Silva comenta que na Bem TV, ainda que este também não seja um objetivo da entidade, há um encaminhamento natural para os jovens que demonstram real interesse pela área:

Aqui na Bem TV, não temos como objetivo a profissionalização. Acaba que ela acontece naturalmente e pontualmente para alguns. [...] Já tivemos jovens que ficaram no projeto cinco anos e depois montaram uma lan house ou entraram na universidade pública ou privada, foram mães, entraram em produtoras... Cada um escolheu que caminho seguir, e entendemos que para todos foi um ganho; uns aproveitaram de uma maneira e outros de outra. Mas essa leitura, só conseguimos fazer anos depois de muita avaliação. [...] Mas sabemos que, para alguns jovens, a questão da profissionalização é muito forte, e temos feito algumas parcerias de encaminhamento. Quando sentimos que para uns é mais evidente, que o menino quer continuar na área, e que gosta, é natural que ele queira ir para uma produtora ou instituição da área de comunicação. (Informação dada por Ana Paula Silva, 2009)

Já a equipe do Cinema Nosso, projeto que surgiu como Nós do Cinema, e durante muitos anos teve sua imagem muito vinculada ao filme "Cidade de Deus" ${ }^{71}$, detectou a necessidade de desvincular discursiva e praticamente o processo de ensino audiovisual a uma potencial inserção no mercado - e o fez especialmente diminuindo a idade e o perfil do público-alvo:

Era difícil fazer com que o aluno entendesse que ficaria um ano no mesmo curso, e que, obrigatoriamente, não tinha nenhuma pretensão de inserção no mercado. E que ele não ia sair empregado dali. Então, como estávamos dialogando com jovens, isso não cabia muito. "Vou ficar um ano tendo que falar em casa que estou aqui e que eu vou sair do 'mesmo jeito que entrei'?" Então, essa questão da diminuição de duração da oficina aconteceu por isso. Quisemos diminuir um pouco a faixa etária para que esse problema da evasão para o mercado não fosse tão forte. Hoje, o pessoal tem em média 16, 17 anos... Decidimos também que íamos trabalhar com estudante de escola pública, e isso, enfim, não era tão fechado. Eles são o público prioritário. Mudou muito a forma como eles chegam aqui: antes chegavam dizendo que queriam ser cineastas, que a vida deles era cinema... [...] hoje temos então que apresentar o que é cinema, o que é audiovisual. Antes a gente tinha o trabalho de desconstruir esse imaginário... (Informação dada por Miriam Machado, 2009)

Neste perfil, se dissemina também com frequência a prática de incorporar, na equipe das entidades, ex-alunos, que passam a atuar especialmente como monitores de gravação e edição, mas também como educadores-aprendizes, e posteriormente, como profissionais.

\footnotetext{
${ }^{71}$ Filme, de 2002, dirigido por Fernando Meirelles - que é uma espécie de padrinho da entidade -, no qual participaram alguns dos fundadores do Nós do Cinema.
} 
Aléxia Melo, da AIC, destaca um problema que surge nesse âmbito: a percepção desses jovens profissionais como mão-de-obra barata - crítica que já ouvi, pessoalmente, repetidas vezes:

Não pode encarar as pessoas que trabalham contigo como mão-de-obra barata. Porque elas aprenderam a fazer seus trabalhos em processos formativos ou em oficinas, não posso desconsiderá-las. Tenho que considerar a formação que elas vêm tendo também. (Informação dada por Aléxia Melo, 2009)

A equipe da AIC, ciente do problema, teve uma postura rara na EAP como em entidades do terceiro setor de maneira geral: optou por contratar esses jovens via consolidação das leis trabalhistas, ainda que os profissionais mais "seniores" não possam ter o mesmo benefício - especialmente em função da citada (no Capítulo 2, item 2.2) irregularidade nos financiamentos. A AIC criou um interessante precedente no âmbito de gestão, que é a potencial pedagogicidade dessas ações (ou o impacto que isso pode ter na entidade de maneira geral), como relata Melo:

Faz mais ou menos uns dois anos que a AIC resolveu assinar carteira; isso causou um impacto nos projetos, inclusive abrimos uma discussão política [...] Então a diretoria não tem carteira assinada e os meninos têm? [...] Abrimos essa discussão: “O que ele é, monitor?”. Fica um ano conosco, e já não é mais monitor, então temos que criar uma categoria para isso - o que não exista no mercado. Então inventamos. É um desafio para o administrador pensar como é que ele vai fazer essa gestão. [...] (Informação dada por Aléxia Melo, 2009)

Especialmente em entidades que promovem atividades de ciclo único, há também profissionais que detectam a necessidade de oferta de uma continuidade às atividades iniciais, visando, em alguma medida, a possibilidade de inserção laboral. Como comenta Paula Kimo, coordenadora da Oficina de Imagens:

Eu sempre achei que a possibilidade (da profissionalização) existe; ela é real e deve ser considerada. Eu sempre "bati o pé” lá na fundação, de que a gente deveria ter um segundo tempo, que seria um segundo nível para aqueles meninos que fizeram parte, que cresceram junto com a ferramenta, que acham que essa ferramenta pode vir a ser alguma coisa - ou nem acham, mas que tenham vontade de continuar e aprender mais. (Informação dada por Paula Kimo, 2009)

\subsubsection{PROJETOS DE PERFIL 3 - DURAÇÃO INTERMEDIÁRIA E LONGA; E}




\title{
ALTA CARGA HORÁRIA (400 A MAIS DE 800h)
}

O Perfil 3, descrito e analisado aqui, remete à inserção laboral - com mais ênfase e propriedade do que quaisquer modelos antes descritos.

\section{Características gerais - Perfil 3}

\author{
Duração intermediária e longa: 90 a 720 dias \\ Carga horária: a partir de $400 \mathrm{~h}$ a mais de $800 \mathrm{~h}$ \\ Total: 10 projetos $(14,29 \%)$ \\ Am FilmesDigitais: Cinema e vídeo na educação (AM) \\ Ação Educativa Projeto: Vídeo: Cultura e Trabalho / CVBE (SP) \\ Central Única das Favelas: Formação Profissional de Jovens para Inserção \\ Sócio-Econômica na Cadeia Produtiva do Turismo (RJ) \\ Movimento do Vídeo Popular: Oficina de Imagem Popular Real Conquista \\ (GO) \\ Giral - Informática, Comunicação e Ação Local: Comunicação (PE) \\ Projeto Cala-boca já morreu: Oficinas de Produção coletiva de vídeo, na \\ perspectiva da Educomunicação (SP) \\ Instituto Oficinas Querô. (Integralmente dedicada à EAP) (SP) \\ Instituto Criar de TV, Cinema e Novas Mídias. (Integralmente dedicada à \\ EAP) (SP) \\ Fundação Criança de São Bernardo do Campo: Usina SocioEducativa (SP) \\ Prefeitura Municipal de Santo André, Escola Livre de Cinema e Vídeo: \\ Escola Livre de Cinema e Vídeo (SP)
}

Nos projetos com esse perfil se estabelecem estratégias organizadas em função de um objetivo concreto a ser realizar ao término da formação do aluno: sua inserção laboral. Os cursos se organizam em etapas planejadas envolvendo atividades que visam simultaneamente a formação técnica e o desenvolvimento pessoal dos alunos.

Duas características estratégicas importantes: o "Instituto Criar", as "Oficinas Querô" e o "Projeto Cala a Boca já Morreu" são entidades integralmente dedicadas ao ensino audiovisual, como todas as implicações positivas já mencionadas no Capítulo 2.3; e o Instituto Criar e o VCT recebem também alunos e ex-alunos indicados por outras entidades. (Os demais projetos têm público livre, com foco nos jovens.)

As atividades geralmente se organizam em ciclos de 1 ano (12 meses) ou 1 
ano e meio (18 meses), nos quais os alunos frequentam, dentro de um mesmo projeto, diferentes cursos.

Grosso modo, os cursos ofertados poderiam ser organizados em dois grandes grupos. Como já propõe o Instituto Criar: oficinas técnicas e oficinas socioculturais.

Através das oficinas técnicas se realizam as atividades mais diretamente conectadas com a prática audiovisual em si. Em geral, os alunos escolhem apenas uma área técnica, na qual irão se especializar ao longo do ciclo. As aulas geralmente são diárias ou em dias alternados (cerca de 2 a 4h/aula por dia).

Já as oficinas sócio-culturais são, em geral, espaços voltados para o desenvolvimento de aprendizados não técnicos, sem foco direto na questão da profissionalização, sob âmbitos muito variados - como veremos adiante. Cada oficina sócio-cultural possui geralmente uma aula semanal, com 2 a 3h/aula por semana.

A questão da profissionalização, em tais projetos, surge como missão ou objetivo geral. Mas aspectos do desenvolvimento pessoal, bem como de suas relações sociais, também se destacam, especialmente nas entidades integralmente dedicadas à EAP. Como no caso do Instituto Criar: "Preparar jovens para que se insiram, se desenvolvam e se realizem no mercado de trabalho; formar jovens que sejam capazes de contribuir com a transformação positiva de seu entorno" (website Instituto Criar, 2009). E das Oficinas Querô: “proporcionar, através da produção audiovisual tão atraente para os jovens - uma captação técnica paralela ao desenvolvimento de habilidades para uma transformação social (website Oficinas Querô).

O objetivo de inserção laboral tem implicações estruturais, nas atividades pedagógicas oferecidas, e também transversais: formas bastante específicas de tratar assuntos do âmbito do desenvolvimento pessoal.

Uma oficina imaginária de Perfil 3, organizada em função de um objetivo concreto (a inserção laboral), e realizado a partir de etapas planejadas, preveria atividades: 


\section{a) oficinas técnicas (cursos obrigatórios de perfil técnico e caráter}

especializado). Tais cursos são voltados a uma formação de cunho técnico em uma das diferentes áreas do fazer audiovisual ofertadas por cada diferente entidade;

No Instituto Criar (IC), por exemplo, há as seguintes oficinas técnicas: Áudio, Animação, Cabelo e Maquiagem, Câmera, Cenografia, Computação Gráfica, Edição, Figurino, Iluminação, Produção, Vídeos Interativos. No caso do IC, o aluno escolhe uma especialização técnica dentre as descritas - oficina que frequentará diariamente e tem uma programação de oficinas socioculturais, às quais ele frequentará uma vez por semana.

Já nas Oficinas Querô (OQ), de Santos, em paralelo a uma série de outros cursos, há um primeiro ciclo semelhante ao de oficinas curtas:

Curso de Audiovisual:

Conteúdo: Elaboração de roteiro; fotografia para cinema; maquiagem; figurino; preparação de set; edição; produção; luz; som; direção; operação de câmera; pós-produção.

Objetivo: Ensinar aos participantes técnicas audiovisuais que serão aplicadas no mercado de trabalho especializado e prepará-los tecnicamente a criar, produzir e finalizar três filmes de curta-metragem até o final do programa. (website Oficinas Querô,)

$\mathrm{E}$ dois cursos cujos temas, amplos, fornecem instrumental para o desenvolvimento de habilidades fundamentais à elaboração de roteiros e à edição de vídeos - e para uma atuação que pode ir além do cinema. Como se vê nas ementas dos cursos citados:

Tecnologia da Informação:

Conteúdo: Aulas práticas de informática e programação; "final cut" e outros programas de edição de vídeo; ensinamento sobre como traduzir seu pensamento em palavras e colocá-las no papel; como elaborar seu currículo.

Objetivo: Ensinar técnicas de TI para os jovens integrantes do projeto não apenas para a redação de roteiros e edição de imagens, mas também para estimular e desmistificar a comunicação via internet (blogs, MSN, chats sociais, comunidades virtuais de debate, etc). (website Oficinas Querô)

Expressão Verbal:

Conteúdo: Estudo da literatura brasileira; análise e interpretação de textos que permitirão o desenvolvimento do vocabulário e de expressão verbal, além da melhora na formulação de ideias, opiniões e críticas; exibição de 
filmes para debate e discussão sobre temas abordados.

Objetivo: Colaborar na melhora da autoconfiança, permitindo que os jovens criem coragem, postura e vocabulário para defender suas ideias e objetivos. "O curso também tem o intuito de estimular a formação de opiniões próprias por meio da leitura e observação crítica de notícias e informações. (website Oficinas Querô)

As oficinas técnicas, no IC, possuem grande importância e são a grande prioridade do projeto. As necessidades destas (por exemplo, os exercícios necessários para desenvolver habilidades profissionais específicas) pautam as oficinas socioculturais - compreendidas também como um suporte ao desenvolvimento das habilidades técnicas e demais necessárias à inserção laboral. Como comenta Danielle Fiabane, superintendente do IC:

Os jovens entram no instituto com uma expectativa de que isso se transforme em uma oportunidade de trabalho, de renda, de independência financeira - que traz uma série de outras independências para eles. Então, sem ferir os seus valores, se você precisa em algum momento, por falta de tempo, por falta de conseguir fazer tudo o que gostaria, priorizar trabalhar certo conteúdo, certa competência.... [...] como nós fazemos aqui. Temos muito mais carga horária de cada oficina técnica do que de cada oficina sociocultural, porque se prioriza a inserção do jovem no mundo do trabalho, os desafios que ele vai ter mais de imediato com essa questão. (Informação dada por Danielle Fiabane, 2009)

No entanto, são os cursos ofertados além dos técnicos, como veremos abaixo, que demonstram a abrangência da formação proposta pelas OQ e pelo IC.

b) oficinas socioculturais (cursos optativos ou obrigatórios de perfil generalista). Tais cursos são voltados ao desenvolvimento pessoal dos alunos, a partir de abordagens diversas.

Há oficinas com perfis mais sociopolíticos, como o curso de "Cidadania" e "Empreendorismo" das OQ. E os de "Realidade Cotidiana" e "Desenvolvimento de Projetos e Ação Social" do IC. Como se vê nas ementas abaixo:

Cidadania:

Conteúdo: Direitos Humanos; Constituição Brasileira; Leis Federais ligadas aos Direitos da Criança e do Adolescente; Leis Federais ligadas ao acesso à Assistência Social.

Objetivo: Preparar os jovens para se tornarem protagonistas em suas comunidades, tendo total compreensão de seus direitos e responsabilidades como cidadãos, e agindo na implementação desse conhecimento em suas vidas. (website, Oficinas Querô) 
Empreendedorismo:

Conteúdo: Desenvolvimento dos aspectos administrativos e financeiros de uma produção cinematográfica, incluindo planejamento, atribuição de responsabilidades, administração orçamentária, captação de recursos e marketing.

Objetivo: Preparar os integrantes na administração do processo produtivo, estimulando o aprendizado de habilidades que poderão também ser utilizadas pelos jovens no desenvolvimento de negócios e na conquista de metas em qualquer área. (website, Oficinas Querô)

Realidade Cotidiana

A oficina tem como objetivo abordar o contexto social, cotidiano e cultural em que os jovens estão inseridos. Pretende estimulá-los a refletir e compreender sua realidade cotidiana através da elaboração de produtos audiovisuais como: documentários, $b \log s$, reportagens. Todos os conteúdos são abordados de maneira prática, a partir das vivências cotidianas dos jovens. Os exercícios desenvolvidos nesta oficina buscam dar subsídios para que eles compreendam temas como cidadania, direitos civis e políticas públicas voltadas para a juventude, entendendo o audiovisual como um importante instrumento de comunicação e transformação dentro de uma complexa rede de interações sociais.

Desenvolvimento de Projetos e Ação Social

A oficina de Desenvolvimento de Projetos e Ação Social prepara os jovens do Instituto Criar para serem empreendedores de projetos sociais e culturais. Nela, os jovens aprendem a identificar uma oportunidade ou uma causa que lhes interesse e desenvolver um projeto. Ao se apropriarem das técnicas básicas de elaboração de projetos sociais e culturais, os jovens ganham autonomia para empreender tanto em suas vida pessoal quanto profissional. "Além disso, tornam-se potenciais multiplicadores do impacto social, sendo capazes de promover uma transformação positiva do seu entorno, um dos objetivos do programa educacional do Instituto Criar". (website Instituto Criar, 2009)

Há também cursos mais voltados ao desenvolvimento das capacidades de expressão e relacionamento interpessoal dos jovens, tais como os cursos de "Humanismo" das OQ e de "Criatividade e Expressão" do IC. Como se vê nas ementas abaixo:

\footnotetext{
Humanismo:

Conteúdo: Baseado em dinâmicas teatrais, os jovens participam de exercícios que permitem realizar novas interpretações sobre situações do cotidiano.

Objetivo: Desenvolver a comunicação e a concentração, assim como estimular os jovens a lidar melhor com sentimentos conflituosos e aprender a confiar e aprofundar os laços com seus colegas. (website Oficinas Querô)

Criatividade e Expressão:

A Oficina possibilita o conhecimento e a expressão da subjetividade de cada jovem e o desenvolvimento de competências pessoais e sociais para a vida pessoal e profissional por meio da arte. (website Instituto Criar)
}

É interessante destacar que o IC não possui mais um curso voltado à formação 
de roteiristas $^{72}$, mas, como nas $\mathrm{OQ}$, oferece um curso mais generalista, que aborda a linguagem escrita de maneira ampla, e que é oferecido a todos os alunos (como oficina sociocultural):

Imagem e Texto:

A oficina tem como objetivo desenvolver nos educandos habilidades de expressão oral e escrita, a partir da produção de textos, roteiros, cartas, sinopses etc. Todos os exercícios propostos estão articulados com as atividades dos exercícios coletivos.

c) saídas ou visitas culturais - atividades aparentemente desvinculadas do processo de aprendizagem audiovisual e que visam, por diferentes meios, estimular aspectos emocionais, intelectuais e sociais dos alunos;

Nos IC, tal dimensão é concebida como "saídas culturais", que são programadas pelos educadores, tanto das oficinas técnicas quanto das socioculturais, e viabilizadas pela entidade e seus parceiros. São realizadas desde visitas altamente específicas de um curso - por exemplo, os alunos de iluminação visitam empresas como Locall e Cinecidade, alunos de produção, as instalações da TV Cultura -, como visitas amplas e voltadas a todos os alunos, como em museus, mostras e peças de teatro.

Nas OQ, a atividade surge como um curso:

\begin{abstract}
Aumentando Horizontes:
Conteúdo: Passeios culturais que incluem museus, peças de teatro e qualquer outra forma de expressão artística brasileira, seguida de um batepapo entre os jovens e os coordenadores a respeito das obras visitadas.

"Objetivo: Democratização da cultura e introdução de elementos da consciência coletiva brasileira que até então eram excluídos da realidade desses jovens por conta de sua situação educacional e sócio-econômica. (website Oficinas Querô)
\end{abstract}

d) aulas ou cursos teóricos especialmente dedicados à História do Cinema ou Audiovisual (panorama); e/ou exibição de trechos de filmes e curtasmetragens dentro das diferentes aulas e processos de aprendizagem; e/ou exibição de filmes brasileiros em lançamento - eventualmente com a participação de membros da equipe ou do elenco, e muitas vezes sucedidos

72 O curso existiu entre 2004 e 2007 até ser extinto, especialmente devido à dificuldade de inserção de seus alunos no mercado de trabalho. 
por um debate.

Como se vê em dois cursos do IC, que são também oficinas socioculturais:

História e Linguagem da TV:

A oficina apresenta um conjunto de conhecimentos sobre as linguagens e história da televisão, tendo em vista a formação de repertório. Explora referências históricas e contemporâneas, nacionais e internacionais. $\mathrm{O}$ objetivo é ampliar a bagagem cultural dos jovens.

História e Linguagem do Cinema:

A oficina apresenta um conjunto de conhecimentos sobre as linguagens e história do cinema, tendo em vista a formação de repertório. Explora referências históricas e contemporâneas, nacionais e internacionais. $\mathrm{O}$ objetivo é ampliar a bagagem cultural dos jovens. (website Instituto Criar, 2009)

Vale destacar que se trata de uma perspectiva privilegiada com relação aos cursos de curta duração e duração intermediária, mas ainda bastante e surpreendentemente distante da carga horária dos cursos universitários de cinema, em que o repertório - nacional e internacional, separadamente - é tema de cursos especialmente dedicados, com carga horária total acima de 1000h, e duração média entre 4 e 6 semestres.

\section{Características singulares}

\section{A reversão dos monitores}

No Perfil 3, como ocorre nos Perfis 1 e 2, se detecta também a ocorrência da incorporação de ex-alunos como monitores. No caso específico do Instituto Criar, os monitores atuavam, desde a segunda turma, com assistentes dos educadores. $\mathrm{Na}$ avaliação da equipe do IC, o papel dos monitores nesse contexto nunca ficou suficientemente claro, e essa posição foi extinta. Como comenta Fiabane:

Eles não existem mais [monitores]. [...] Os educadores delegavam para eles tarefas, papéis e responsabilidades que não eram deles, então, se "esvaziavam" uma série de vezes das suas responsabilidades, se "esvaziavam" de prestar atenção no jovem como se o monitor fosse um intermediário da relação entre ele e o jovem, o que não era para ser. Os monitores ora eram super assistentes, ora eram "ninguém", dependia de 
quanto o educador estava precisando dele naquela hora, e eles também não entendiam "que diabos de papel" eles tinham ali. Uma hora eles tinham que tirar xérox e arrumar a sala, a outra hora eles tinham que dar uma aula, o que não era o papel deles, ficar sozinho com os meninos. Então, cada vez mais se notava a ausência dos educadores, e isso jogava a responsabilidade nas costas deles [dos monitores]. Achamos que isso não era positivo, e que tínhamos que dedicar um tempo enorme para eles conseguirem se constituir como parte da equipe, e esclarecer dúvidas, frustrações, expectativas. (Informação dada por Danielle Fiabane, 2009)

É curioso como a proximidade de idade entre eles, que sugere a horizontalidade elogiada pelos profissionais dos Perfis 1 e 2, aqui é tida como um ponto negativo, especialmente quando se leva em conta que os alunos estão sendo preparados para um mundo do trabalho no qual essa horizontalidade é praticamente inexistente. Como segue Fiabane:

A proximidade de idade entre eles e os alunos era o tempo todo uma questão; eles não tinham às vezes a postura para ser exemplo. Nem sempre tinham postura para ser exemplo positivo, e isso se desdobrava em uma série de consequências. (Informação dada por Danielle Fiabane, 2009)

\section{Importância do Desenvolvimento Pessoal}

A própria estrutura dos cursos de Perfil 3 sugere uma forte preocupação com o desenvolvimento de habilidades que permitam aos alunos crescer nos âmbitos emocional, intelectual e social. A emergência de diversos cursos de perfil sociocultural, em grande parte desvinculados da formação técnica, denota o nível de preocupação que as entidades têm com esses âmbitos da preparação dos jovens.

No Cinema Nosso, no Perfil 2, detectou-se a necessidade de um profissional para auxiliar o educador a enfrentar seus desafios - e ele atua diretamente em sala de aula, juntamente com o educador. Já no Perfil 3, a atuação de profissionais que dêem suporte para os desafios psico-pedagógicos do cotidiano é praticamente uma précondição para que o curso transcorra.

No IC, havia inicialmente apenas a figura do coordenador educacional. E as educadoras de "Criatividade e Expressão" assumiam informalmente o papel de auxiliar os educadores nesse contexto. Recentemente, o IC passou por uma reformulação, e uma das educadoras desse curso passou a atuar nesse papel 
formalmente:

O que a gente fez então foi contratar uma pessoa para fazer orientação pedagógica. Hoje, a gente chama de assessora pedagógica, que é a Téia. A Teia, que é psicopedagoga, que cuidava da oficina que a gente chama de "Criatividade e Expressão", era uma pessoa que indiretamente acabava sendo procurada pelos educadores para entrar nesses detalhes, principalmente na relação educador e educando. Então a gente convenceu a Teia, na verdade, (risos) a assumir esse desafio com a gente há um ano. Hoje ela atende cada educador quinzenalmente, por uma hora e meia, para discutir o seu plano de curso, suas dificuldades, o que ele quiser trazer (ela recomenda leitura), enfim, é um trabalho bastante focado. E a partir desse trabalho, a gente também começou a se sentir mais seguro de colocar o que a gente espera, mais do que a gente fez ali naquele primeiro momento. A gente espera, acima de tudo, que ele seja um bom educador social. E o que é ser um educador social? Não é minha linha de expertise, mas, pelo o que eu consigo decifrar disso, é uma pessoa que tenha a capacidade de transmitir a técnica, de promover um espaço para que aquele jovem desenvolva suas próprias habilidades em determinada área. Mas, principalmente, a forma como ele faz isso, também é muito importante que seja construtivista, que não seja uma simples reprodução do modelo que a gente vê na escola tradicional, e que leve em conta o universo social de onde esses jovens vêm. Porque ele é diferente, muitas vezes requer um outro tipo de trabalho... (Ibidem)

No instituto Criar realiza-se também, semestralmente, reuniões com os pais dos alunos. Já nas OQ, há um espaço sistemático e especialmente dedicado à integração do projeto com as famílias dos jovens:

Encontro com Pais:

Conteúdo: Por meio de dinâmicas e bate-papo, o Encontro com Pais busca informar os pais sobre o projeto e sobre o apoio social e psicológico disponível, além de destacar a importância da participação da família no programa.

Objetivo: Manter os pais dos jovens integrantes sempre informados sobre a participação de seus filhos no projeto, bem como estimular a abordagem de temas que podem afetar a união familiar. (website Oficinas Querô) 
Um grupo de 2 projetos não será aqui analisado diretamente, pois seu perfil extremamente atípico (720 dias de aula e carga horária entre 20 e 80h/aula) não permite que seja categorizado em nenhum dos perfis citados. ${ }^{73}$ Além disso, nenhuma dessas entidades participou dos questionários da segunda etapa, apesar dos diversos convites feitos por email, de forma que não há dados que permitam uma apresentação das características inerentes a esse que poderia ser um quarto perfil de projeto.

\section{Resultados}

Este capítulo tem como objetivo apresentar alguns parâmetros e resultados colhidos com o intuito de avaliar o impacto das experiências da EAP sob o ponto de vista de alguns resultados mensuráveis e da percepção que os alunos e ex-alunos têm do próprio aprendizado, especialmente sob o viés do desenvolvimento de habilidades e aprendizados cuja sistematização pedagógica foi apresentada nos capítulos 3 e 4 .

\subsection{Resultados Mensuráveis}

Este subcapítulo tem como objetivo demonstrar como a experiência da EAP é percebida socialmente, a partir da circulação dos produtos audiovisuais realizados em seus projetos, e da inserção laboral de seus alunos - mesmo quando este não é o principal objetivo das entidades.

\subsubsection{VIDEOS PRODUZIDOS, FESTIVAIS, TELEVISÃO}

Muitos profissionais ligados a entidades que atuavam no início dos anos 2000 defendiam a primazia do processo pedagógico ao resultado fílmico-audiovisual das oficinas. No entanto, os educadores e entidades foram amadurecendo, e a qualidade

\footnotetext{
${ }^{73}$ Casa de Cultura Tainã, Produção de Vídeos utilizando Software Livre, SP; Imagem na Ação - núcleo de desenvolvimento de projetos de comunicação e cidadania; TV Pinel, RJ.
} 
das produções cresceu significativamente - especialmente ao longo da primeira década do século 21. Segundo estimativas das próprias entidades, foram realizados mais de 3200 vídeos nesses vinte anos.

Existia um ceticismo inicial com relação a essa produção. Nos primeiros fóruns da Formação do Olhar havia uma crítica generalizada à qualidade dos vídeos apresentados. E em artigo publicado no tabloide da Formação do Olhar de 2004, o cineasta Maurício Hirata afirmou que o tratamento então dado pela mídia às experiências da EAP dava uma maior ênfase aos processos das diferentes Oficinas do que a seu resultado, sugerindo um olhar condescendente:

Ao se concentrar nos efeitos sociais da realização de oficinas mais do que
na estética dos filmes, cria-se uma separação entre esta produção e a
produção artística "de fato". Os vídeos de oficinas são desconsiderados
enquanto obra acabada e, portanto, passível de crítica tanto quanto
qualquer outro filme. No mundinho do cinema esta produção é
considerada, ainda, "café com leite". (Hirata, tabloide da Formação do
Olhar $\left.^{74}, 2004\right)$

De fato, durante muitos anos, as obras resultantes dos projetos da EAP - que opto denominar "Cinema de Quebrada" - eram grosso modo consideradas como “obras em processo", e só eram acessíveis para o público em Festivais. Até 2004, apenas o Festival de Curtas possuía uma seção especialmente dedicada a tais produções; as obras simplesmente não circulavam.

Aos poucos, essa produção vem rompendo barreiras, em parte, pela ampliação de janelas que a exibe, e pelo próprio nível técnico que tem sido alcançado pelas produções.

Produções da EAP já figuraram na programação de Festivais Brasileiros e internacionais, e foram exibidas em: canais abertos e públicos como a TV Cultura, a TV Brasil, a TV PUC, o Canal da Cidade e o extinto canal SescSenac; a cabo, como o Canal Brasil e o Canal Futura; e internacionais, como os canais Nickelodeon e CNN Internacional. No entanto, a exibição nessas janelas não é, nem nunca foi, sistemática - ocorre apenas em eventos pontuais, ou programas curtos dedicados ao tema.

74 Disponível em www.kinooikos.com, acessado em 23 de maio de 2008. 
As produções da EAP que têm figurado na TV brasileira têm como origem um grande número de diferentes entidades. Segundo o mapeamento, a participação das produções, em festivais como na televisão, vem crescendo, ainda que timidamente, nos últimos dois anos. No período anterior a 2008, 30\% das entidades tiveram ao menos uma de suas produções exibidas na televisão. Entre 2008 e 2009, esse número subiu para $46,2 \%$.

É importante destacar que isso significa que ao menos uma, dentre as produções da entidade, foi exibida ao menos uma vez. Reitero: não significa, de modo algum, que as entidades possuam veiculação sistemática na televisão, o que ocorre apenas com alguns projetos, tais como a Rede Jovem de Cidadania, da AIC, que tem seus programas veiculados semanalmente na Rede Minas, e os vídeos produzidos pelas entidades sob encomenda e exibidos no Canal Futura ${ }^{75}$.

O universo dos festivais é, sem dúvida, um espaço já melhor ocupado pela EAP. No período anterior a 2008, 63,1\% das entidades tiveram ao menos um dos vídeos resultantes de seus projetos exibido em festivais. Entre 2008 e 2009, esse número subiu para $73,4 \%$.

É importante, no entanto, analisar também o contexto em que os vídeos são exibidos dentro dos festivais. Ainda existe uma forte segmentação: há festivais especialmente dedicados a públicos compartilhados com a EAP (com critérios variados); há festivais que organizam essa produção em programas especiais; e há uma pequena parcela da produção que vem buscando integrar a curadoria dos programas principais dos Festivais, em meio a vídeos e filmes realizados por profissionais.

Nos dois primeiros casos citados, a produção resultante da EAP é vista dentro de seu contexto de produção. E características que vão além de sua qualidade fílmica/audiovisual podem ser levadas em conta. É interessante destacar que a forma

\footnotetext{
75 Diversas entidades vêm atuando como prestadoras de serviço, e produzindo conteúdo para programas e interprogramas do Canal Futura. A parceria foi citada nas entrevistas, e foi motivo de polêmica: com relação ao que as entidades consideraram baixa remuneração e excesso de intervenção nos produtos.
} 
de seleção e curadoria, nos diferentes festivais, também varia muito. Na Formação do Olhar, seção do Festival Internacional de Curtas Metragens especialmente dedicada ao tema, a curadoria funciona de forma semelhante ao funcionamento da curadoria dos demais programas do Festival, porém com parâmetros diversos e em muito menor escala:

a) monta-se uma equipe de curadores em geral composta pelo coordenador da seção (papel que ocupei entre 2004 e 2008) e mais dois ou três convidados - selecionados ano a ano dentre profissionais e egressos de projetos sociais com especial interesse e atuação na área;

b) os vídeos inscritos, antigamente em VHS e hoje em dia em DVD, circulam entre os curadores e a coordenação. Cada curta possui uma ficha impressa que circula junto com ele, na qual os diferentes profissionais anotam suas impressões e a partir das quais os debates são orientados;

c) no processo individual de análise, co-existem dois critérios básicos e sequenciais: em primeiro lugar são avaliados aspectos puramente cinematográficos, em que os vídeos são analisados como seriam os filmes profissionais, sob aspectos técnicos, narrativos e de linguagem; essa análise é anotada sinteticamente na ficha, juntamente com uma avaliação geral sobre a inserção do vídeo na programação. Essa avaliação geral se dá nos seguintes termos: Sim, Talvez, Não, Talvez Sim e Talvez Não, gerando uma primeira gradação entre os diferentes vídeos. Essas informações são, em seguida, inseridas em um banco de dados;

d) a partir dessa primeira gradação, é então realizado um filtro no Banco de Dados, em que se organizam os vídeos avaliados como "Sim", verificando:

- o número total de vídeos e a minutagem,

- se algum projeto teve mais de um vídeo selecionado,

- se algum projeto não teve nenhum vídeo selecionado.

Procura-se evitar que algum projeto tenha um volume desproporcional de 
produções, mas isso não significa deixar de selecionar os melhores vídeos. Em alguns anos, entre 2004 e 2008, chegamos a selecionar 5 vídeos de um mesmo projeto - e tivemos o cuidado de conferir tal resolução. Evita-se também que algum projeto fique completamente de fora da seleção. Entre 2004 e 2006 isso ainda era possível; mas, desde 2007, há projetos que acabaram ficando completamente de fora da seleção quando todos os vídeos da entidade não alcançam, na avaliação dos curadores, uma média de "Talvez Sim". Com isso, temos tido a preocupação de evitar que a Formação do Olhar resvale justamente nesse espaço "café com leite" sugerido por Hirata em 2004.

Não posso afirmar qual é o exato perfil de curadoria dos demais festivais que exibem produções da EAP. Mas minha experiência tem demonstrado que, entre os Festivais integralmente dedicados ao tema, como o Visões Periféricas, o Jovens Realizadores do Mercosul, o Favela é Isso Aí, os Festivais de Vídeo locais que tem dado espaço à essa produção e algumas mostras únicas que eventualmente são realizadas, é possível se perceber algumas tendências:

a) o "Visões Periféricas" não diferencia a produção feita no contexto da EAP de produções que tematizam a periferia, mesmo que realizadas por profissionais da classe média. A curadoria não parece ter pretensões de apresentar um panorama da produção recente específica da EAP, apesar de contar com uma ampla programação, que é organizada tematicamente, demonstrando o caráter cinematográfico da curadoria. Como observa Márcio Blanco, diretor do Festival:

O Festival Visões Periféricas está cada vez mais indo no sentido de uma visão não da periferia mas uma visão de quem está à margem dos meios de comunicação de massa, seja ele da periferia ou do centro, é de uma visão mais holística que tem mais a ver com as novas tecnologias. (BLANCO, 2009)

b) o Festival Jovens Realizadores do Mercosul tem um recorte bastante específico, etário - tanto no sentido de quem produz como de quem assiste, com as inerentes implicações temáticas. Ou seja, o recorte do Festival sugere que sua curadoria tematiza a juventude nas duas pontas: da produção e da exibição; 
c) mostras especiais como a Formação do Olhar, a Mostra Geração do Festival do Rio de Janeiro (que tem dez anos de existência), e festivais como o Favela é Isso Aí, de Belo Horizonte, aparentemente buscam simultaneamente valorizar o desenvolvimento da linguagem e apresentar um panorama da produção nacional.

Em suma, os vídeos circulam excepcionalmente bem por tais festivais e seções temáticas, e ainda timidamente nos festivais de maior prestígio, onde mesmo os realizadores profissionais têm encontrado forte concorrência na última década ${ }^{76}$.

A questão da premiação segue a mesma lógica. 45,71\% das entidades declaram que um ou mais vídeos do projeto foram premiados em Festivais. No entanto, exceção feita ao projeto Vídeo nas Aldeias, que possui alta circulação e penetração no circuito dos maiores Festivais Nacionais e Internacionais, e a alguns casos excepcionais, os prêmios recebidos pelos vídeos dos projetos são, em geral, oferecidos:

a) em festivais de vídeo de perfil mais local, normalmente localizados dentro dos estados de origem dos próprios projetos;

b) em festivais especialmente dedicados para a EAP, como o Visões Periféricas e/ou Jovens Realizadores;

c) e/ou nas seções especiais de Festivais, caso da Formação do Olhar, do Festival de Curtas de São Paulo.

Essa análise não desmerece, em nenhuma medida, as conquistas obtidas nesse âmbito. Mas sugere que essa produção ainda não convenceu, sob os parâmetros mais tradicionais, a rígida crítica dos curadores e jurados dos festivais.

No entanto, vale destacar que, ao longo dos anos, alguns vídeos produzidos no contexto da EAP conseguiram uma trajetória notável, circulando plenamente por festivais de prestígio nacionais e internacionais. Caso de diversos vídeos do projeto

\footnotetext{
${ }^{76}$ Podemos supor que isso tem ocorrido devido ao forte crescimento da produção audiovisual brasileira na última década, bem como do volume de profissionais formados pelos diversos e crescentes cursos universitários de cinema e audiovisual, e também pelas entidades da EAP. No mesmo período o número de festivais temáticos e locais aumentou, mas o número de vídeos e filmes exibidos pelos grandes festivais não.
} 
Vídeo nas Aldeias, além dos citados abaixo:

A festa da Moça (1987 / 18min. / Nambiquara)

(Premiado nos Festivais: Latin American Vídeo Festival, NY, E.U.A.,1992

/ IV Festival de los Pueblos Indígenas, Peru, 1992/ VIII Festival del Cine

Latino Americano, Trieste, Itália, 1993)

A arca dos Zo'é (1993 / 22min. / Waiãpi / Zo'é)

(Prêmios: JVC President's Award, 16 Tokyo Video Festival, Tóquio, Japão, 1993

Prêmio Curta Metragem, 16 Festival International de Films Ethnographiques et Sociologiques CINÉMA DU RÉEL, Centre George Pompidou, Paris, França, 1994 Melhor Vídeo, II Mostra Nacional de Cinema e Vídeo de Cuiabá, 1994)

Imbé Gikegü, Cheiro de pequi (2006 / 36min. / Kuikuro)

(Prêmio de Melhor Curta-metragem, Festival Présence Autochtone de Terres en Vue, Montréal, Canadá, Junho de 2007)

MARANGMOTXÍNGMO MÏRANG Das crianças Ikpeng para o mundo (2001 / 35min. / Ikpeng)

(Prêmios:Valor testimonial y documental, do VII Festival Internacional de Cine y Vídeo de los Pueblos Indígenas, Santiago do Chile e Melhor Documentário no All Roads Film Festival, da National Geographic, em Los Angeles e Washington).

E também de outros vídeos e, especialmente, filmes realizados em 35mm:

*"Portinholas", do Instituto Marlin Azul/ Projeto Animação, filme em 35mm realizado em técnica de animação 2D exibido em diversos festivais em meio a filmes profissionais. Recebeu menções honrosas em festivais de prestígio como o $26^{\circ}$. Festival de Havana (Cuba) e o $27^{\circ}$ Festival Guarnicê (MA), além do prêmio especial do júri, em Animação, do FAM - 8º Florianópolis Audiovisual Mercosul (SC), 2004.

* "Um táxi para o devaneio", filme em 35mm de Éder Augusto e Ansgar Ahlers, realizado pelas Oficinas Kinoforum em parceria com Daydreams, projeto alemão coordenado por Ahlers e Dirk Manthey. O filme recebeu os prêmios da TV Cultura no Festival de Curtas de SP e da mostra Sala de Aula do Festival de Porto Alegre (RS).

* "Uma garota e uma arma" (A girl and a gun), de João Paulo Miranda Maria, aluno do projeto KinoOlho de Rio Claro, foi premiado no "Mobile Phone Movie Competition", um concurso de filmes para celular promovido pela CNN International, e foi exibido com destaque na rede. Para se ter uma dimensão da visibilidade que o 
vídeo alcançou, em apenas um mês a CNN chega a ter 64 milhões de espectadores diferentes, somente nos Estados Unidos.

* Diversos filmes e vídeos de entidades variadas que compõem o acervo da UNESCO: "Mangue e Tal” (2002), "Portinholas"(2003), “Zen ou não Zen”(2004), "Brincando na Aldeia"(2006), do Instituto Marlin Azul, "A new life in the favelas", de Luis Carlos Nascimento, presidente do Cinema Nosso.

Exceções feitas, o panorama geral aponta para um crescimento na visibilidade da produção, bem como um significativo avanço em sua qualidade. No entanto, verifica-se também que ainda não se alcançou o último estágio de um possível desenvolvimento da sua linguagem, no sentido do reconhecimento mais frequente pelas equipes de curadoria e júri dos festivais de maior prestígio, como da crítica cinematográfica. O pesquisador Gustavo Souza está, no presente momento, investigando essa produção ${ }^{77}$, em busca de vestígios da construção de uma linguagem própria, e ampliando essa discussão para outros campos e fronteiras.

\subsubsection{PROFISSIONALIZAÇÃO E INSERÇÃO EFETIVA}

Havia, no questionário geral das entidades, dois campos de múltipla escolha voltados exclusivamente à aferição de estatísticas vinculadas à questão da inserção laboral. Os dados coletados nestes campos estabelecem um primeiro panorama sobre os resultados obtidos nesse âmbito.

Em resposta à questão “A entidade possui estratégias de inserção profissional para seus alunos?", muitas entidades declaram não possuir estratégias de inserção formal:

a) $41 \%$ das entidades declaram não possuir estratégias de inserção profissional para seus alunos, evidenciando uma não preocupação com o tema, ou, como citado por alguns, a compreensão do processo como "um efeito colateral";

77 Tese de doutoramento em realização na ECA/USP, sob orientação do professor Henry Gervaiseau, como o título provisório "Pontos de vista em documentários periféricos". A previsão de término (depósito) é fevereiro de 2011. 
b) um total de $44 \%$ das entidades declara possuir apenas estratégias informais de inserção profissional para seus alunos, demonstrando que, para muitas delas, ainda que um "efeito colateral", a profissionalização é inevitável, e por conseguinte, benvinda.

Já em resposta à questão "Quantos, dentre seus alunos, você acredita que são inseridos no mercado após o término das atividades?", muitas entidades afirmam inserir poucos ou nenhum de seus alunos no mercado: 60\% das entidades acreditam que poucos de seus alunos efetivamente entrem para esse mercado. E $17 \%$ das entidades acreditam que nenhum de seus alunos o faça.

Esse primeiro conjunto de estatísticas dá respaldo à análise feita no capítulo item 2.6, em que se concluía que, no total, para 75\% dos projetos, a inserção laboral não configura o principal objetivo, demonstrando alguma coerência discursiva nas entidades da EAP.

Um pequeno conjunto de entidades possui estratégias formais de inserção laboral. Dentre as entidades pesquisadas, $12 \%$ declaram encaminhar os alunos para estágios e empregos, e 1\% declara ter parceria com central de estágios, totalizando $13 \%$ que declaram uma preocupação formal e prática com a inserção de seus alunos.

Com relação à efetiva inserção dos alunos no mundo do trabalho, $9 \%$ das entidades acreditam inserir cerca de metade de suas turmas, e $8 \%$, muitos de cada turma, totalizando $17 \%$ de entidades que acreditam promover a inserção laboral de mais da metade de suas turmas, a cada ciclo.

Lembrando (como vimos no Capítulo 2) que 14\% das entidades afirmam ter como objetivo a profissionalização, e $11 \%$ o empreendedorismo, pode se afirmar observando todos esses dados em conjunto - que a inserção laboral não é o principal problema que a EAP busca resolver, mas é um dos principais.

E se levarmos em conta que a profissionalização de seus ex-alunos tem ocorrido após oficinas de todos os perfis - a despeito da não intencionalidade de 
alguns -, podemos considerar que a inserção laboral configura, sim, um âmbito em que a EAP conseguiu estabelecer avanços e resultados significativos (afinal, cerca de $17 \%$ das entidades acreditam inserir metade de cada turma ou mais no mercado de trabalho - o que representa um número significativo de profissionais inseridos anualmente).

\subsection{Ponto de Vista dos alunos}

Este subcapítulo tem como objetivo apresentar um panorama geral dos alunos e ex-alunos da EAP, bem como uma visão geral de como eles percebem o processo das oficinas e cursos e o próprio aprendizado.

\subsubsection{DE ONDE VÊM OS NOSSOS DADOS?}

Um total de 82 alunos preencheu o questionário específico na internet; desse total, 7 alunos foram entrevistados presencialmente. Mas os dados das entrevistas são muito irregulares com relação ao conjunto de dados apresentado aqui, por isso essas entrevistas não serão citadas. Quantitativamente, trabalho apenas com o universo de 82 alunos que preencheram o questionário.

Os 82 alunos que preencheram são oriundos de 12 diferentes entidades, como se vê no gráfico abaixo: 


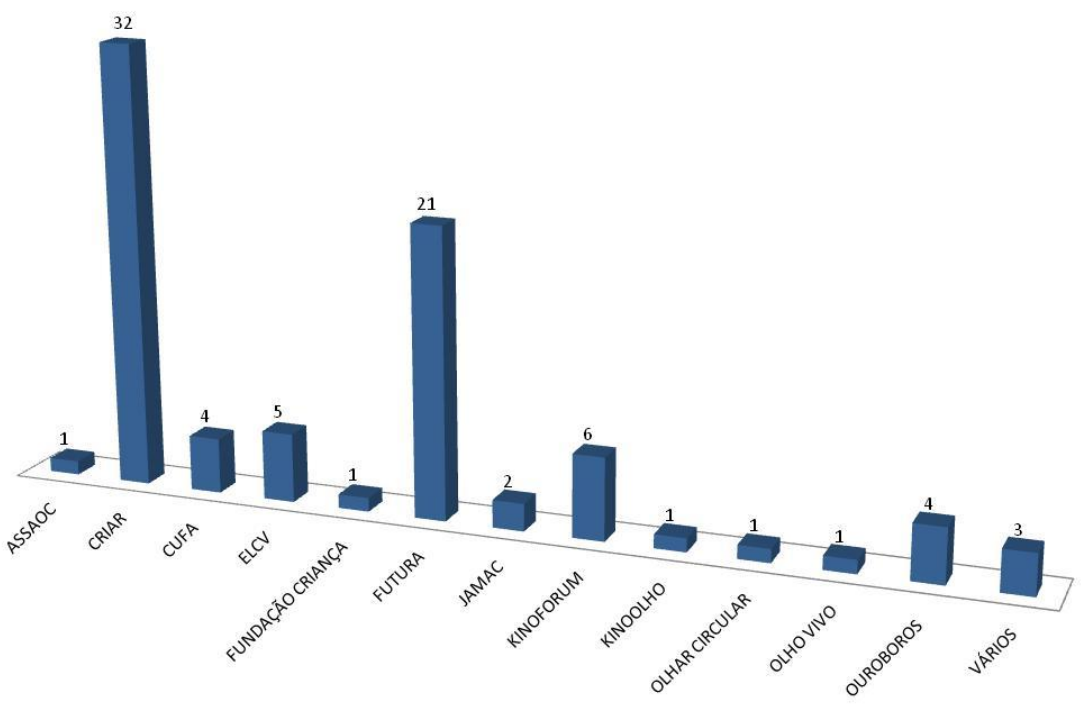

Fonte: Questionário Alunos e Ex-alunos, 2009.

Gráfico 10. Entidade de origem dos alunos que preencheram o questionário.

Observando esses dados, percebe-se que:

a) aluno de 1 projeto, cuja entidade não participou do mapeamento, tomou conhecimento do mapeamento e preencheu. (Aluno do projeto Olhar Circular, com $1 \%)$;

b) $24 \%$ dos alunos representam um total de 9 entidades, de perfis variados. $\mathrm{E}$ os $76 \%$ restantes dividem-se em apenas 3 entidades, cada uma de um perfil;

c) 3 alunos participaram de mais de 2 projetos (categorizados como "Vários"), o que, pela minha experiência, é até mais comum do que esse dado sugere.

A entidade que contribuiu com maior número de alunos foi o Instituto Criar, de perfil 3 (mais voltado à inserção laboral), com 39\%; seguido do Geração Futura/Canal Futura, de perfil 2 (de duração e carga horária mais intermediários), com 25,3\%; e das Oficinas Kinoforum, de perfil 1, com 7,6\%.

Ainda que exista alguma diversidade em uma análise geral, é importante ressaltar que pode existir, especialmente em algumas categorias de dados, algum 
impacto sobre os valores totais, dos dados de alunos do Instituto Criar e do Geração Futura. Mas, pelo que avaliamos, não há implicações significativas no caso específico dos dados de interesse a essa tese.

\subsubsection{BREVE PREFÁCIO AO SUBCAPÍTULO}

Os entrevistados, ao falar dos processos pedagógicos, referiram-se aos alunos dos projetos como "meninos", somente no capítulo 3, vinte vezes. No total, dentre todos os dados coletados, o termo foi utilizado 58 vezes. O termo é, sem dúvida, utilizado com muita frequência por profissionais que atuam no campo. E não revelaria tal ato falho ${ }^{78}$ uma evidência na abordagem?

A figura do "menino", extremamente presente na cultura brasileira, seja na literatura, na música, nos remete a "uma criança do sexo masculino". No Dicionário de Língua Portuguesa de Aurélio Buarque de Holanda, é considerado também um "tratamento familiar afetuoso dado a pessoas do sexo masculino, ainda que adultas" (FERREIRA, 1999, p. 1316). A partir desta etimologia podemos estabelecer que se trata, sem dúvida, de um ato falho, altamente revelador com relação ao tipo de envolvimento que os profissionais, em geral, estabelecem com seus alunos: um ambiente de afetividade que tem, sem dúvida, uma fronteira tênue com a atmosfera e as relações familiares ${ }^{79}$.

Os alunos da EAP são, sem dúvida, meninos e meninas que revelam diante dos diversos profissionais que trabalham com eles, todo um novo universo de troca de afetos e integração de valores. São, de longe, a maior motivação para a superação dos inúmeros desafios enfrentados no cotidiano e para o crescimento da Educação Audiovisual Popular.

\subsubsection{QUEM SÃO ESSES ALUNOS?}

\footnotetext{
78 “Ato falho", segundo a teoria da psicanálise, seria, grosso modo, uma atitude, ou especialmente, uma palavra ou frase, em que o autor, ao tentar dizer uma coisa, evidencia uma intenção contrária ou distinta.
} 
A faixa etária dos alunos que preencheram o questionário varia entre 16 e 40 anos, com grande ênfase (60\%) nos chamados "vinte e poucos anos": $37 \%$ entre $21 \mathrm{e}$ 24 anos, e $23 \%$ entre 25 e 29 anos.

A faixa etária entre 16 e 20 anos, foco exclusivo de trabalho do Instituto Criar, aparece com 29,27\% dos entrevistados - sendo que metade dessas menções é de alunos e ex-alunos do IC. $8 \%$ dos entrevistados têm mais de 30 anos, e são oriundos dos seguintes projetos: ELCV, Jardim Miriam Arte Club (JAMAC), CUFA, IC e Oficinas do Centro de Cultura Judaica da Ouroboros. Nas demais faixas etárias, a participação por entidade é bastante variada.

Esses meninos e meninas vêm construindo, coletivamente, todo um novo imaginário audiovisual ${ }^{80}$, no qual, em muitos momentos, pretendem representar um pouco de si mesmos. Então, bem ao modo lúdico da EAP, ao mesmo tempo em que fazemos a análise, buscaremos construir um aluno imaginário, como a um personagem de uma narrativa audiovisual.

\subsubsection{UM ALUNO DA EAP}

Um personagem precisa de um nome. Fosse esta tese sobre Cinema Italiano e ele talvez se chamasse Guido ${ }^{81}$. Sobre cinema brasileiro recente, certamente seria Zé Pequeno ou capitão Nascimento. Dadas as devidas proporções, alguns personagens também se tornaram célebres na EAP, a partir da ampla visibilidade obtida pelos vídeos nos quais figuravam.

Puxando pela memória, lá no começo dessa história da EAP, me vem a lembrança da senhora que perguntada, diz que "é feliz", e em seguida, perguntada novamente, plano idêntico, segundo take, diz que "não é". O filme, "Defina-se", realizado por parte da equipe da Filmagens Periféricas nas Oficinas Kinoforum, foi

\footnotetext{
${ }^{80}$ Não pretendemos aqui novamente esgotar o debate sobre se essa produção implica ou não em um novo estilo de cinematografia, tarefa que caberá certamente a outros pesquisadores, como Souza.

${ }^{81}$ Guido é o nome do cineasta interpretado por Marcello Mastroiani no filme autobiográfico e metalinguístico " 8 e $1 / 2$ ", de Federico Fellini, de 1963.
} 
analisado em diferentes pesquisas, e teve excelente circulação para os padrões da época. Lembro também do rapaz do primeiro filme do Cinema Nosso que vi, "Cidadão Silva", e seu desespero que acaba virando uma roleta russa. O requinte técnico da produção não me sai da memória. Lembro também de Tato, o jovem do vídeo homônimo produzido também nas Oficinas Kinoforum, que procura emprego pela cidade, sem sucesso. Em um filme que começa e termina com Tato fumando maconha e olhando para o vazio.

Que dizer então de Mc Maiquinho - personagem (e integrante real) da TV Morrinho, cantor de funk -, que ao ser convidado para cantar o samba-enredo da escola de sua comunidade (Acadêmicos do Morrinho), tem receio de transitar de um gênero a outro, e acaba paralisando o carnaval até sua chegada? ${ }^{82}$

São muitos os personagens interessantes. No entanto, infelizmente, ainda não há registro de produção e lançamento de longas-metragens realizados no contexto da $\mathrm{EAP}^{83}$ - contexto em que seria mais fácil e comum o surgimento de muitos outros personagens complexos.

Mas existe um vídeo que, por motivos diversos, foi capaz de construir os personagens para mim mais inesquecíveis: "Mulher de Amigo", dirigido por Leandro Monteiro e realizado pelo coletivo carioca Boca de Filme, composto por ex-alunos do Cinemaneiro - dentre eles, Josinaldo Medeiros, já amplamente citado.

O filme possui diversos personagens. Os principais são Dim, Don e Kojac, três amigos que moram em Cidade de Deus. Don e Kojac são evidentemente envolvidos com o crime, mas o personagem que me interessa aqui é Dim (interpretado pelo ator Kinho Lima). Como em uma divertida e inconsciente resposta ao megahit "Tapa na pantera", Dim surge como uma vítima de seu vício: dorme, se esquece dos compromissos com os amigos, é absolutamente inconsequente; mas nunca apaga o cigarro de maconha. Na sequência final do vídeo, depois de suas ações terem

\footnotetext{
${ }^{82}$ Vídeo realizado sob encomenda e exibido no canal Nickelodeon.

${ }^{83}$ Há registros de realização de longas-metragens digitais por alunos das primeiras turmas da Escola Livre de Cinema e Vídeo de Santo André, que, no entanto e infelizmente, nunca alcançaram veiculações televisivas, circuito consistente de festivais ou salas comerciais.
} 
desencadeado até a morte de um rapaz, Dim diverte-se com Dom, fazendo um ritmo com a voz (o chamado Beat Box) a partir do qual o amigo improvisa um pagode-rap inspirado no título do vídeo.

Evitando qualquer debate sobre o tema do vídeo, e suas implicações, o personagem Dim é fantástico: bem interpretado, natural, engraçado, enfim, praticamente um clown. Alcança um grau de naturalidade e empatia que deixou muitos realizadores de fora do Rio de Janeiro querendo entender, no maior bomhumor, como é que "os cariocas fazem isso".

Então, sem maiores delongas, o nome do nosso personagem imaginário, em homenagem já justificada, será Dim.

\section{Perfil do Personagem - Quem é Dim?}

Dim, 22 anos $^{85}$, é branco ${ }^{86}$, solteiro $^{87}$, não tem filhos ${ }^{88}$ e mora com os pais ${ }^{89}$. A renda familiar é de cerca de $\mathrm{R} \$ 1000^{90}$. Terminou o ensino médio ${ }^{91}$, mas ainda não entrou na faculdade - apesar de ter vontade de fazê-1o ${ }^{92}$.

\subsubsection{MOTIVAÇÃO}

Os alunos buscam os projetos da EAP por motivos muito diversos, que indicam, dentre outras coisas, que a realização audiovisual vem despertando naturalmente o interesse dos jovens.

Respondendo à questão "Por que você procurou a Oficina/Projeto?”, 64,7\%

84 Os itens de perfil geral dos alunos pesquisados serão apresentados em síntese criativa. Os dados completos serão inseridos em notas de rodapé.

85 Idade: entre 16 e 20 (29,87\%); entre 21 e 24 (37,80\%); entre 25 e 29 (23,17\%); acima de 30 anos (8,54\%); não respondeu $(1,22 \%)$.

86 Raça declarada: negro (18,29\%); branco (46,34\%); mulato/pardo (29,27\%); outro (2,44\%); não respondeu $(3,66 \%)$.

87 Estado Civil: solteiro (93,90\%); casado $(6,10 \%)$.

88"Filhos: nenhum (92,68\%); um (3,66\%); dois $(3,66 \%)$.

89"Mora com os pais?": $\operatorname{sim}(65,85)$; não $(34,15 \%)$

90 “Renda familiar": até $\mathrm{R} \$ 1000$ (42,68\%); entre $\mathrm{R} \$ 1000$ e $\mathrm{R} \$ 2000$ (24,39\%); entre $\mathrm{R} \$ 3000$ e $\mathrm{R} \$ 4000$ (14,63\%); acima de $\mathrm{R} \$ 4000(7,32 \%)$.

91 “Terminou o ensino médio?”: $\operatorname{sim}(92,68 \%)$;não $(7,32 \%)$.

92 “Está cursando ou quer fazer curso superior?": não está cursando e pretende cursar (54,88\%); está cursando $(21,95 \%)$; é formado (13,41\%); não está cursando e não pretende cursar $(2,44 \%)$; não respondeu $(7,32 \%)$. 
dos alunos optaram (em múltipla escolha) pela seguinte resposta: "Porque eu sempre quis aprender cinema e surgiu a oportunidade". A segunda resposta mais escolhida foi "Para descobrir coisas novas", com 17,6\% das respostas.

Novamente desmistifica-se um pouco a questão de o interesse dos jovens estar necessariamente ligado apenas a uma urgência por profissionalização. Apenas 8,8\% indicaram ter procurado o curso "Para aprender uma profissão".

Como na história de JC relatada no prefácio, 5,9\% dos alunos matriculam-se nos cursos por já fazerem outros cursos, e sem ter muita consciência do que iriam encontrar: procurei o curso "porque eu já fazia outro curso e me interessei, mesmo sem saber o que era".

Por fim, apenas 2,9\% responderam procurar o curso "para descobrir uma nova forma de se expressar", o que, de alguma forma, me parece desconexo do evidente objetivo de expressão que as oficinas promovem intrinsecamente. Ou seja, poucos procuram essa formação acreditando no seu potencial expressivo, de antemão.

Motivação do personagem (plot): Dim sempre teve desejo por descobrir coisas novas. Tinha interesse em aprender cinema, e um dia surgiu a oportunidade: estava passando por uma praça em que estava ocorrendo uma projeção pública, sentou-se para assistir, e ouviu o anúncio de inscrições para uma oficina audiovisual. Inscreveuse, e foi selecionado.

\subsubsection{EXPECTATIVAS ${ }^{93}$}

Os alunos que participam de projetos da EAP possuem três expectativas principais com relação aos cursos e oficinas - em alguma sintonia com o discurso das entidades: aprendizado técnico (mencionado por $41,03 \%$ dos alunos), oportunidades profissionais $(19,95 \%)$ e crescimento pessoal $(19,07 \%)$.

\footnotetext{
93 Trata-se de campo livre onde realizei uma análise qualitativa, a partir da qual criei essas subcategorias.
} 
Motivação secundária do personagem (expectativas): ter um aprendizado técnico e, possivelmente, atuar profissionalmente na área.

\subsubsection{O ALUNO - DIA ZERO}

Os alunos da EAP que participaram do mapeamento não têm dificuldades em falar dos próprios desafios e dificuldades, tampouco de suas conquistas. Demonstram ser bastante autocríticos e atentos ao próprio desenvolvimento.

Em uma avaliação sobre o momento da entrada no curso, os alunos apontam como suas principais características e desafios pessoais ${ }^{94}$ :

a) timidez/ dificuldade de se relacionar $(28 \%)$;

b) falta de maturidade de suas habilidades intelectuais e de trabalho (17\%);

c) indecisão profissional $(12,07 \%)$;

d) dificuldade de trabalhar em grupo $(10,34 \%)$.

Já no campo de múltipla escolha sobre o mesmo tema ${ }^{95}$, os alunos indicam como principais desafios pessoais (também no momento de entrada):

a) auto-conhecimento (39\%);

b) concentração $(14,6 \%)$;

c) sociabilidade $(11 \%)$;

d) aprendizagem $(7,3 \%)$.

Não parece existir tampouco embaraço ao falar dos preconceitos que se julgava possuir no momento da entrada no projeto (53\% declaram que tinham algum tipo de preconceito, sendo os mais presentes: classes sociais, 15,7\%; opção sexual, $15,7 \%$; religião, $7,2 \%$, e opiniões opostas às suas, $7,2 \%$ ).

\footnotetext{
94 Trata-se de campo livre, em que havia uma pergunta: "Conte um pouco sobre como você era antes da Oficina" e um subtítulo: "Fale sobre sua atitude, se era tímido ou extrovertido, se tinha dificuldades de relacionamento, etc".. A partir das respostas, realizei uma análise qualitativa, e com base nela, criei essas subcategorias e também as seguintes: Falta de proatividade/ resignação $(6,9 \%)$; Tinha pouco conhecimento sobre audiovisual $(6,9 \%)$; Imaturidade e/ou perspectivas equivocadas $(7,76 \%)$; Não tinha grandes desafios/não percebeu grande diferença após o curso (11,21\%).

95 Nessa questão, há itens de múltipla escolha e também um espaço ("Outros”), em que os alunos podiam também redigir respostas originais. Os campos de múltipla escolha e as respostas inseridas no campo "Outros" foram consolidados em uma matriz única, a partir de similaridades. Além das respostas citadas no texto acima, foram citados os seguintes desafios: interesse $4,9 \%$, família $1,2 \%$, liderança, e 20,7\% declararam não ter nenhum desafio específico.
} 
Os dados também sugerem, paradoxalmente, não se tratar de uma geração de jovens especialmente preconceituosa ( $47 \%$ declara que não tinha nenhum tipo de preconceito).

Uma análise desse conjunto de dados sugere que os alunos da EAP avaliam seu desenvolvimento e desafios no momento de entrada no projeto sem receio de se expor, e o fazem com bastante autocrítica, especialmente no que tange aos seus objetivos de formação técnica, e seus desafios no âmbito pessoal.

Uma análise mais aprofundada sugere ainda que o claro reconhecimento dos desafios de âmbito pessoal descrito no campo de redação livre (como timidez, dificuldade de se relacionar e de trabalhar em grupo) alinha-se claramente com a própria indicação do maior desafio (dentre os itens ofertados em múltipla escolha) como sendo o autoconhecimento, denotando, por sua vez, justamente o desenvolvimento de algum autoconhecimento por parte dos alunos.

Características e desafios pessoais do personagem: Dim é tímido e tem alguma dificuldade de concentração. Fala pouco de si mesmo. Sempre teve um pouco de preconceito de classe social, ou como se costuma dizer, com relação aos "playboys"96. No começo do filme, está bastante indeciso com relação à sua carreira profissional.

\subsubsection{UM FILME IMAGINÁRIO}

Antes de falar do impacto, precisamos ter as primeiras cenas do filme imaginário. Ora, se temos um personagem imaginário, temos que ter um filme!

\section{Sala de Aula de Projeto de Educação Audiovisual, INT, DIA}

Dim está em uma sala de aula cheia de jovens. Um professor jovem, cerca de 30 anos, entra em sala de aula. Corta para o pensamento de Dim: uma sequência de

\footnotetext{
96 Playboy costumava definir um estilo de vida. No entanto, na gíria da periferia, define genericamente um jovem da classe média ou alta que possui maior poder aquisitivo.
} 
filme de ação, perseguição, música. Corta para a sala de aula e claramente trata-se de outro momento: os alunos organizados em grupos e debatendo entre si. Dim integrase a um dos grupos e debate fervorosamente. Corta para:

\section{Ruas próximas à entidade, EXT, DIA}

Dim e seu grupo gravam uma cena em um ponto de ônibus. Entrevistam pessoas. Gesticulam, mudam a câmera de lugar repetidas vezes. Corta para:

Voltam caminhando para a entidade quando começa a escurecer.

A convivência entre diferentes classes sociais, pessoas de diferentes opções sociais e religiosas, dentre outras diversidades, possui um papel central - tanto para os alunos como para a equipe - na superação de $\operatorname{preconceitos}^{97}$, ainda que isso não seja um consenso.

Um total de $40,5 \%$ dos alunos vê essa questão em um chave positiva, acreditando que a convivência no projeto ajudou a superar preconceitos, pelos seguintes motivos: $12,5 \%$ porque a convivência em grupo o fez respeitar as diferenças e se modificar; $5 \%$ porque conheceu alguém que o fez mudar de opinião; $2,5 \%$ porque passou a experimentar novas formas de ser e de agir; $20,25 \%$ por diferentes motivos.

Um total de $35 \%$ vê em uma chave neutra: $20 \%$ dos alunos acreditam que tiveram uma experiência prévia que não lhes incutiu preconceitos, ou se declararam contra preconceitos; "sem resposta" ou "não quis comentar", $8,75 \%$

Um total $13,75 \%$ dos alunos veem a questão em uma chave negativa: sendo que destes, apenas 2,5\% dos alunos afirmam continuar a ter preconceitos e que a experiência surtiu pouca diferença positiva; 6,25\% declararam que não houve qualquer alteração a partir da Oficina; e 5\% declaram ainda possuir preconceitos, mas acreditam que - em chave parcialmente positiva - a experiência surtiu muita diferença.

E em uma chave crítica, 3,75\% dos alunos afirmam também ter sofrido

\footnotetext{
${ }^{97}$ Trata-se de dados oriundos da tabulação dos dados do campo, a partir da qual criei essas subcategorias.
} 
preconceito e ter tido que lidar com o assunto.

Esse conjunto de dados sugere que a convivência em projetos da EAP possui um impacto altamente positivo na superação de preconceitos - uma vez que não os estimula e, para 40,5\% dos alunos, ajuda a superá-los.

\section{Sala de leitura da entidade, INT, DIA}

Dim e dois amigos conversam sobre as gravações realizadas. Um dos amigos defende que eles deveriam entrevistar um estudante universitário de classe média sobre o tema do filme. Dim fica reticente, não tem interesse em filmar o "playboy". Convencido pelo grupo de que a cena é importante, segue com os amigos para a entrevista. Corta para cenas variadas durante e após a entrevista. Dim e os amigos tomam uma cerveja com o estudante e dão risadas.

\subsubsection{A TRANSFORMAÇÃO}

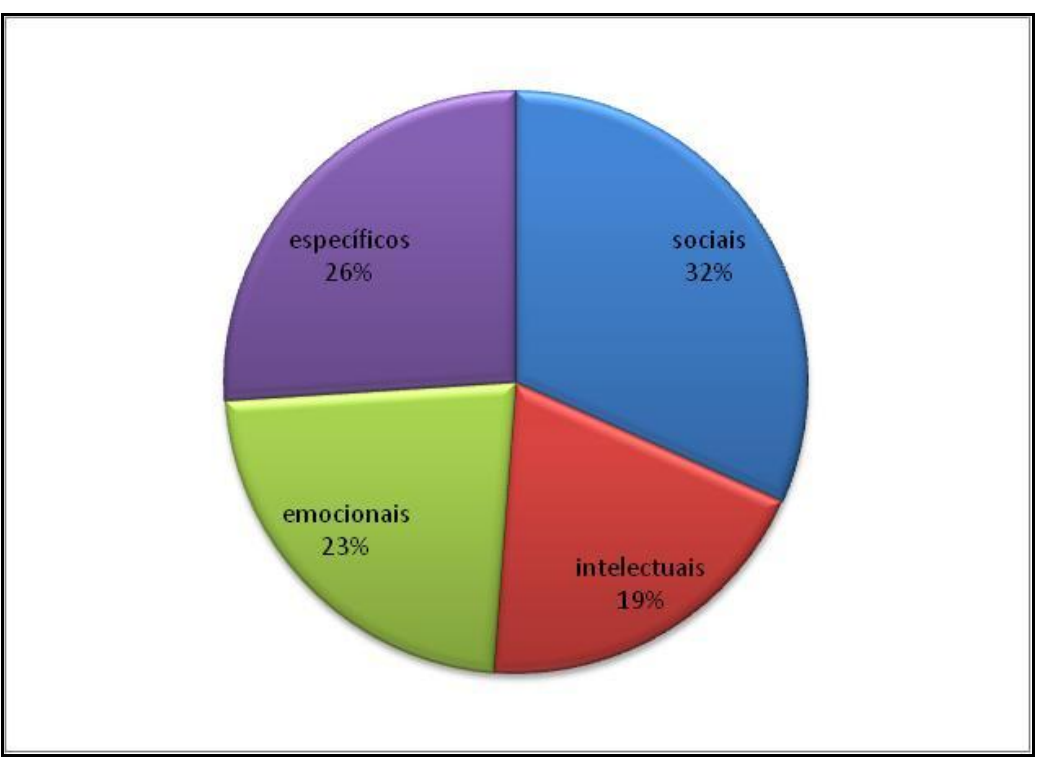

Fonte: Questionário com os alunos, 2009.

Gráfico 11 - Percepção dos alunos sobre os próprios aprendizados

No gráfico da Figura acima, submetemos o campo "Indique aqui quais você acredita que foram seus principais aprendizados a partir da Oficina/Projeto 
Audiovisual" à mesma análise qualitativa a que foram submetidos os objetivos das entidades, coordenadores e educadores, para detectar em que medida as preocupações destes coincidem com as conquistas que os alunos julgam ter tido.

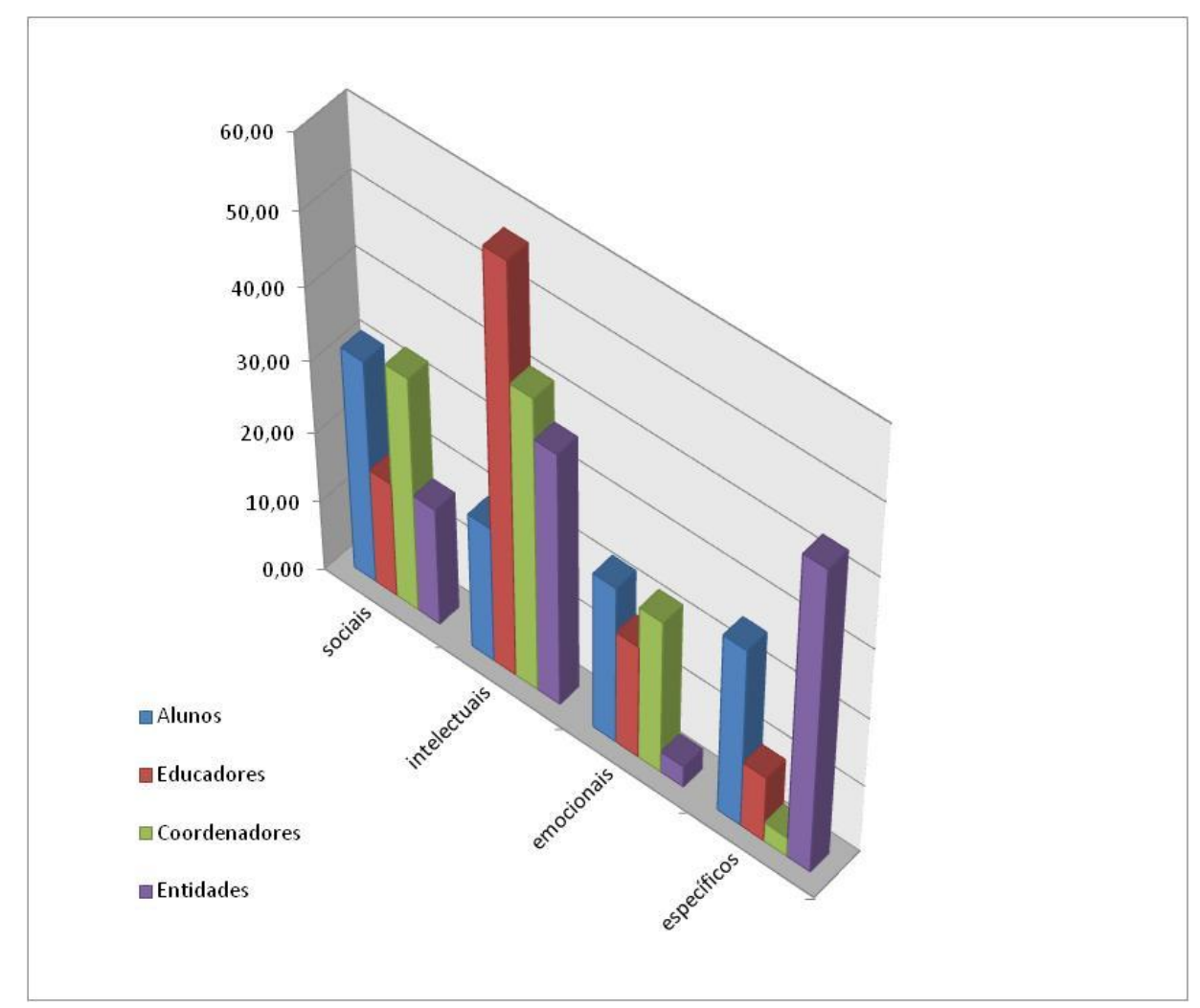

Fonte: Questionários com Entidades, Coordenadores e Educadores. 2009.

Gráfico 12 - Habilidades identificadas nos objetivos das entidades versus habilidades que os educadores e coordenadores buscam despertar versus habilidade que os alunos acreditam ter desenvolvido

Retomando a análise cruzada entre os discursos das entidades, coordenadores e educadores, e trazendo para o debate o ponto de vista dos alunos sobre os aprendizados que acreditam ter construído (como se vê no gráfico acima), temos que:

a) A percepção dos alunos dá a entender que há um excelente resultado no que tange a preocupação geral e significativa das entidades, coordenadores e educadores com o desenvolvimento de habilidades sociais, tais como: aprender a trabalhar em equipe; ouvir críticas/criticar; ter tolerância; conviver; engajar-se; estabelecer contatos; exercitar a liderança. (Entre 16 e $33 \%$ das menções de entidades, coordenadores e educadores remetem a esse universo, e $32 \%$ das menções dos alunos remetem a aprendizagens 
construídas também neste universo);

b) os alunos não aparentam detectar o desenvolvimento de habilidades do âmbito intelectual como as entidades, coordenadores e educadores almejam. Entre $36 \%$ e $58 \%$ das menções destes últimos remetem ao desenvolvimento de habilidades intelectuais, tais como: ampliar o repertório; aprender a observar; pesquisar; organizar/sintetizar; criticar; analisar; expressar-se. Contra 19\% das menções dos alunos. Há que se destacar que tais habilidades exigem alto grau de autoconhecimento para que sejam detectadas;

c) como vimos, entre educadores, coordenadores e entidades há uma preocupação desigual com o desenvolvimento de habilidades emocionais (entre $3 \%$ e $22 \%$ ), demonstrando que há um campo de problemas definido e comum, mas que talvez ainda esteja sendo um pouco negligenciado, tanto na ponta (pelos educadores, com 16\%) como na base (na gestão da entidade, com apenas 3\%), deixando possivelmente os coordenadores ( $22 \%$ das menções) isolados com a preocupação e busca de soluções para o assunto. Pois bem, os alunos dão respaldo à preocupação dos coordenadores, com $23 \%$ das menções remetendo a aprendizagens nesse âmbito;

d) os alunos dão respaldo, com $26 \%$ das menções, ao objetivo específico de formação para a área audiovisual (que é uma preocupação desigual, indo de $3 \%$ a 44\%). O nível de percepção dos alunos com relação a seu aprendizado específico (26\%) encontra eco nos objetivos das entidades, em que chegam a $44 \%$ as menções nesse sentido. Se os educadores $(10 \%)$ e coordenadores (3\%) não se preocupam tanto com esse âmbito, é porque, em alguma medida, tendem a priorizar amplamente o desenvolvimento de outras habilidades no processo. Mas o fato é que os alunos percebem essa formação técnica. Ou seja, ainda que esse não seja o maior objetivo dos educadores e coordenadores, a estrutura do projeto em si, e o foco em outros aspectos da formação têm dado conta de auxiliar os alunos na construção dos conhecimentos específicos da área audiovisual. 


\section{PRAÇA DA COMUNIDADE, EXT, FIM DE TARDE}

Dim filma um horizonte de milhares de casinhas, ao longe. Abaixa a câmera e a desliga. Observa a praça. Seus colegas de curso montam uma tela, formada por um tecido amarrado em duas árvores. Ele se junta aos amigos. Corta para:

\section{PRAÇA DA COMUNIDADE, EXT, NOITE}

Dim testa o microfone. Respira fundo. Sobe no palco.

Créditos.

Os dados tabulados referentes a alterações no projeto de vida dos alunos indicam que duas grandes transformações são claramente percebidas pelos alunos: um interesse irreversível pelo audiovisual, e uma mudança significativa nos modos de pensar e de estar no mundo.

Como se vê no conjunto dos dados coletados (em resposta a: "Como seu envolvimento com o audiovisual interferiu no seu projeto de vida? Algo mudou?"), $34,95 \%$ : decidiram se dedicar profissionalmente ao audiovisual ou definiram esse interesse em detrimento de outras atividades. 29,13\%: mudou sua forma de pensar, de engajamento ou concepção de mundo. 11,65\%: ampliou os interesses para outras áreas de conhecimento ou atuação. 8,74\%: mudou diretamente o cotidiano. 4,85\%: o envolvimento promoveu o convívio com pessoas ou experiências emocionais importantes. 4,85\%: o projeto de vida se manteve, sempre teve envolvimento com a temática ou foi uma continuidade. 5,83\%: nada mudou, não houve interferência.

Como o conjunto de dados apresentado neste "capítulo" sugere, a participação em uma oficina ou projeto de ensino audiovisual promove, de maneira geral, transformações significativas no projeto de vida dos alunos. Para uns, o audiovisual surge como campo de trabalho; para outros, serviu como meio para adquirir um maior senso crítico perante os meios de comunicação; e ainda, para outros, surgiu como auxílio para superar preconceitos, circular e aprender a trocar nos diferentes ambientes sociais, dentre outras conquistas. O que há, de transversal e comum a 
todos, é um grande aprendizado em âmbitos muito diversos, que modificam de maneira decisiva e positiva o modo destes jovens de estar no mundo.

\begin{tabular}{|l|}
\hline Epílogo \\
VÁRIOS, INT/EXT, DIA \\
Trilha sonora. Dim pega o celular. Disca. Corta para/ Uma mão atendendo o celular. \\
Corta para um dedo tocando a campainha. Corta para a sala da casa de Dim. Ele está \\
trabalhando, sério, em uma mesa, em meio a papéis, calculadoras, telefones. O plano \\
abre, e o vemos conversando sobre os papéis com o universitário, o "playboy" que \\
entrevistou quando fez seu filme. Os dois riem. Black out. \\
\hline
\end{tabular}




\section{Conclusão}

No início deste trabalho, estabeleci como objetivo realizar uma sistematização do que parecia ser um conjunto de percepções, práticas e trajetórias compartilhadas entre as diferentes entidades que promovem a EAP. Minha hipótese era que tais elementos se consolidariam como um campo (a Educação Popular Audiovisual) em que se estabeleceriam diálogos mais ou menos explícitos com o campo correlato da Educação, em geral, em especial com o subcampo que identificamos como das "Educações Alternativas e Democráticas" - tanto em suas teorias como em suas experiências práticas.

Teria nossa hipótese se confirmado? $\mathrm{O}$ que nos demonstraram os dados e análises desta tese?

Há um caminho histórico razoavelmente claro conduzindo o movimento cineclubista, a fundação dos cursos universitários e, especialmente, o vídeo popular, à Educação Audiovisual Popular (EAP), que ocorre e se inscreve num paradigma neoliberal, com implicações claras no modelo de gestão de pessoas e financiamento das entidades, além de alguma - ainda que bastante velada - autocensura.

Essa auto-censura ficou clara quando, como pesquisadora, mas também como agente do campo, percebi em muitos discursos - especialmente nos presenciais - uma omissão constante dos desafios mais negativos que há no âmbito do financiamento e que, como descrevi, tem graves implicações tanto na sustentabilidade dos projetos como dos profissionais que neles atuam.

Os dados dos questionários, mais impessoais, deram respaldo a essa percepção, demonstrando também que EAP é uma experiência significativamente abrangente, em aspectos geográficos, humanos e artísticos, e sugerindo certa urgência pela delimitação do campo da Educação Audiovisual Popular (ou termo similar), de modo que possa existir: 
a) alguma evolução na sustentabilidade das entidades que a promovem, vistas de fato como organizações de interesse público - ao contrário do modelo atual, em que os financiamentos são, em geral, destinados a projetos, com ciclos definidos e sujeitos às intempéries políticas, instabilidades do mercado e dos lucros auferidos pelas empresas patrocinadoras.

b) Uma possível regulamentação profissional do campo, que permita que aqueles que nele atuam possam ter acesso a formação especializada e que se possam instituir instâncias efetivas de representação de seus interesses.

c) A sistematização mais constante e profunda de suas práticas, de modo que as efetivas e significativas conquistas realizadas possam ser aproveitadas como ponto de partida para o desenvolvimento de políticas públicas.

Os objetivos da EAP, talvez estes sim possam eles ser chamados de “messiânicos". Pelo que vimos nos Capítulos 4 e 5, é uma experiência que se propõe a, especialmente, sensibilizar seu público de modo a promover nos alunos uma nova forma de estar, de se expressar e interagir no mundo, a partir de uma formação audiovisual que, se promove a inserção laboral, o faz como a um "efeito colateral" positivo.

$\mathrm{O}$ universo de habilidades e aprendizados que as entidades e profissionais buscam promover é muito amplo, e inclui - supreendentemente, e de forma destacada - uma preocupação significativa com o desenvolvimento de habilidades intelectuais, como ampliar o repertório, aprender a observar, pesquisar, organizar, sintetizar, criticar, analisar e se expressar.

As habilidades e aprendizados que se busca promover - e como vimos, de fato promove - remetem à noção de competências, e para Perrenoud, "os mobilizam, mas não são em si saberes". Ou seja, são conquistas que os alunos realizam a partir da formação nos projetos da EAP, adquirindo potencial para replicar em outro âmbito de suas vidas, e facilitando o aprendizado constante, e de saberes diversos. 
Note-se como as competências citadas remetem diretamente à epistemologização da curiosidade (Freire), a que aludimos no Capítulo 3.1 As oficinas realizam, nos primeiros dias, atividades extremamente lúdicas, que estabelecem desafios. A partir do estranhamento inicial, os alunos empreendem um circuito que vai se autoalimentando: a partir da curiosidade ingênua inicial, são estimulados a partir para a pesquisa. Buscam referências, assistem filmes e, especialmente, experimentam cientificamente - por exemplo, gravam livremente, mudando parâmetros, e depois comparando os resultados e realizando uma síntese crítica. Aos poucos, ao realizar novas e mais aprofundadas críticas sobre o próprio trabalho e o dos demais, surge a necessidade de criar signos que estabeleçam sentidos para aspectos que eles mesmos detectam. E, naturalmente, se vê a transição para um pensamento crítico-analítico, em que a mediação do mundo por conceitos começa a se tornar uma ferramenta - não em um sentido estrito, mas no sentido de permitir que cada conceito seja construído por eles, mesmo que já existam, de tal forma que a compreensão seja natural.

Esse circuito de aprendizado intelectual talvez seja o principal aspecto comum às diferentes entidades, materializando o "Zeitsgeist" sugerido na introdução.

Os dados sobre a forma como as entidades utilizam autores e métodos como ponto de partida para suas atividades demonstram que esse "Zeitsgeist" é bastante inconsciente. Mais de 30\% das entidades da EAP sequer reconhecem a existência de uma metodologia, afirmando desenvolver suas atividades sem utilizar quaisquer autores ou métodos como ponto de partida. No entanto, detecta-se, em todas elas, a criação cotidiana de meios originais de promover a formação audiovisual. E se a grande maioria das entidades afirma possuir proposta metodológica - desenvolvida de maneira totalmente original, ou utilizando como referência diferentes autores e métodos, mais do que uma implantação estrita das propostas metodológicas de referência -, constrói-se muito mais uma espécie de pedagoDia do ensino audiovisual - na qual as decisões no cotidiano pedagógico são tomadas a partir de alguma intuição, e em diálogo (apenas em parte consciente) com autores e métodos previamente estudados.

Eu sabia, de antemão, que Freire era e é uma presença frequente nas práticas e 
discursos da EAP. Mas a sua onipresença ( $80 \%$ dos que citam algum autor, o citam) me pegou de surpresa, deixando claro que a extensão de sua obra vem permitindo que sua referência seja percebida em âmbitos variados, como na atuação dos educadores, nas instâncias de participação e nas abordagens militantes. Além de, especialmente, suas proposições sobre a epistemologização da curiosidade, desenvolvimento que, como citamos acima, a EAP tem dado conta - intencionalmente ou não - de promover nos alunos que forma.

O diálogo com a educação democrática e campos correlatos foi detectado, também e especialmente, no que tange aos aspectos pedagógicos de quatro âmbitos justamente compartilhados com o universo das escolas: a gestão, o espaço, a adesão e a interação.

E são justamente as condições que a EAP estabelece em tais âmbitos que criam o cenário ideal para a promoção dos mais variados aprendizados e habilidades, tal como os objetivos da experiência sugerem:

a) a gestão é considerada um elemento central, no qual a participação dos alunos - em instâncias diversas - é, como sugeriram também os dados qualitativos, uma estratégia comum e, quando experimentada com maior profundidade, decisiva. Se não há uma prática frequente de cogestão ou gestão compartilhada, como se vê nas escolas democráticas, há uma preocupação decisiva com a participação de maneira ampla.

b) apesar de arquitetonicamente não existir grande diferença com relação às salas de aula das escolas, as entidades consideram a pedagogicidade do espaço e suas implicações, buscando ao máximo criar ambientes agradáveis e que estimulem a convivência. E o Projeto Morrinho, do Rio de Janeiro, ilustra como essa pedagogicidade pode ser levada a um paroxismo, remetendo livremente à ideia de uma educação que ocorreria nos espaços sociais e produtivos das cidades - remetendo a outro precursor da educação democrática, Anísio Teixeira, como à prática de projetos como o Cidade Escola Aprendiz, o Bairro Escola de Nova Iguaçu e às polêmicas propostas de Ivan Illich pela desescolarização da sociedade. 
c) alimentação durante o período do curso, auxílio-transporte e bolsa de estudos são elementos muito frequentemente oferecidos aos alunos nas entidades da EAP, que o fazem sob o argumento de que se trata de algo imperativo para garantir o conforto necessário à frequiência dos alunos ao curso, desencumbindo-os de pressões familiares e, em suma, facilitando a adesão ao curso; aqui, destaca-se a preocupação com o conforto e com a desconstrução do paradigma tradicional de escola.

d) liberdade de atuação e estímulo à experimentação pedagógica, exploração (em geral com implicações positivas, mas também negativas) das fronteiras afetivas, algum sentimento de responsabilidade pelos alunos, por parte dos profissionais, e o desenvolvimento de estratégias diferenciadas de avaliação com vistas a um acompanhamento ágil do desenvolvimento dos alunos. Forma de abordar o tema que remete a Alves, Pacheco, Freire, Garroux e Antunes e, seminalmente, a Jean Jacques Rousseau.

Trata-se de um cenário sem dúvida um tanto difícil de se construir em uma escola formal. Mas dá a dimensão do abismo entre o ambiente destas e das entidades em que se promove a EAP. E ainda evidencia:

a) os excelentes resultados obtidos pela EAP com relação ao despertar de aprendizados e habilidades, especialmente intelectuais e sociais, desafios compartilhados - e que, evidentemente, a escola sofre a crônica dificuldade de superar.

b) o potencial impacto do estímulo a aspectos filosóficos da educação democrática, como a participação e a fragilização das fronteiras do afeto.

Neste cenário, a implantação de estratégias "out of the box" é amplamente facilitada e, respeitadas as diferenças destacadas entre os diferentes perfis de oficina que sistematizamos no Capítulo 4, fica claro que existem aspectos transversais que apontam para tal "Zeitgeist":

a) o citado e oportuno oferecimento de atividades que promove um circuito de desenvolvimento intelectual no qual, a partir de estímulos diversos, os alunos aprendem a realizar um audiovisual de modo técnico, muitas vezes 
sem se dar conta dos inúmeros outros aprendizados a que estão sendo estimulados paralelamente;

b) exercícios e jogos lúdicos envolvendo a linguagem audiovisual por vias diversas, nos quais se evidencia o desejo de se oferecer uma oportunidade de aprendizado mais complexa, com clara ênfase na realização de exercícios nos quais, por diferentes meios, se promovem o desenvolvimento de habilidades de convívio e colaboração social, e a construção de conceitos - juntamente com os alunos e a partir da crítica à própria experiência;

c) inserção laboral intencional ou não, a partir do oportuno desenvolvimento de habilidades e aprendizados emocionais, sociais e intelectuais, que acaba implicando na formação de pessoas capazes de aprender de maneira constante, em convívio respeitoso e profissional - como queria Neill em Sumerhill -, o que resulta, naturalmente, em uma nova relação com o mundo e uma maior competitividade no mercado de trabalho.

Temos, por fim, que a EAP renova, em alguma medida, teorias e práticas de campos correlatos - como ensino universitário, vídeo popular, educação e escolas democráticas -, conquistando excelentes resultados sob parâmetros diversos, e possivelmente justificando o alto volume de investimento afetivo, profissional e financeiro que tem recebido.

"Mas qualquer modo de ensinar audiovisual promove, sempre, uma transformação positiva?". Evidentemente que não. E o que os dados sugerem é que há uma altíssima incidência de boas práticas e de reflexões sobre estas ainda mais relevantes, especialmente nas experiências que inspiram e da forma como recriam práticas comumente associadas à educação democrática e campos correlatos. Práticas e reflexões que, sob o ponto de vista pedagógico, revelam-se, nesse sincretismo, singulares e originais.

Talvez os dados levantados não nos permitam, ainda, afirmar que a Educação Audiovisual Popular constitua, em si, um campo. Mas espera-se que, a partir dos dados e análises realizados, possa se estabelecer um ponto de partida para que outros 
pesquisadores investiguem outras problemáticas e fronteiras inerentes a esse processo.

Relendo esta tese, por fim, percebo o quanto meus objetivos originais, ao iniciar o projeto, se transformaram. Desde o princípio, meu interesse sobre o tema focava a riqueza pedagógica da atuação dos profissionais que a promoviam - nos quais sempre vislumbrei uma riqueza e criatividade ímpares.

No entanto, como fica claro para mim agora, de fato atuei como uma pesquisadora participante, e o próprio ato de pesquisar o tema mais a fundo, assim como o diálogo com os profissionais que encontrei neste período, foram pouco a pouco moldando uma nova visão, que dialogava e dialoga com um discurso com o qual convivi intensamente desde a entrada no programa de pós-graduação: a urgência de que se realizasse um trabalho de fôlego sobre o tema, que desse conta de apresentar e, em alguma medida, sistematizar a diversidade e riqueza das práticas em curso - em uma perspectiva mais ampla que o tema da atuação de seus profissionais, ainda que inclua essa dimensão.

Assim, com certo descontentamento, mas também segura do valor que esta contribuição científica pode vir a ter para a experiência coletiva da EAP, abri mão de me concentrar exclusivamente nos temas que são, de fato, minha maior paixão. E empreendi diversos e dolorosos cortes temáticos e textuais, especialmente sobre aspectos extremamente específicos da atuação de coordenadores e educadores, que distanciariam a tese dos objetivos por fim assumidos, gerando longas digressões. Mas não posso deixar de destacar aqui que a atuação dos profissionais da EAP apresenta inúmeros meandros a serem explorados e problematizados - por todos que, como eu, se encantem com a riqueza pedagógica de sua atuação que, espero, tenha transparecido ao longo desta empreitada.

Outro aspecto que gostaria de destacar é a infinidade de leituras, conexões e aprendizados que o processo de elaboração desta tese propiciou - aprendizados que certamente permearam cada linha desta pesquisa, cujas implicações foram e serão decisivas e transformadoras sobre meu modo de ser e estar no mundo. 
Combater o desperdício da experiência: esse foi meu lema durante esses quatro anos. Espero ter alcançado meu intento. E por fim, apenas para apontar um caminho - em uma perspectiva totalmente pessoal - relato que o projeto Morrinho é a experiência educativa mais revolucionária com a qual já tive contato. Vivenciar uma tarde entre os jovens - que brincavam livremente na maquete - me fez vislumbrar a materialização da ideia de uma sociedade desescolarizada, como proposto por Ivan Illich: de Morrinho em Morrinho, certamente estaríamos promovendo uma melhor formação, mais participativa e efetivamente transformadora do que a de nossas gerações escolarizadas. 


\section{Referências Bibliográficas}

ABRAHAM, B. Janusz Korczak (1878-1942): Coletânea de pensamentos. São Paulo, 1986.

AGUIAR, L. J. D. M. R. E. Olhar Arrevesado: Estudo de caso sobre a produção audiovisual de localidade na cidade do Rio de Janeiro. Mestrado, Niterói. Acessado em http://www.bdtd.ndc.uff.br/tde_busca/arquivo.php?codArquivo=1163, 2005.

ALVARENGA, C. M. C. D. Vídeo e Experimentação Social: um estudo sobre vídeo comunitário no Brasil. Mestrado, Campinas, SP. Acessado em www.doc.ubi.pt/01/teses_clarisse_alvarenga.pdf, 2004.

ALVES, R. Por uma educação romântica. São Paulo: Papirus.

A escola que eu sempre sonhei sem imaginar que pudesse existir. São Paulo: Papirus, 2001.

Um bairro que virou escola. Campinas, SP: Papirus, 2004.

ANTUNES, C.; GARROUX, D. Pedagogia do Cuidado. Petrópolis: Vozes, 2008.

BARBA, E. Além das ilhas flutuantes. Campinas, SP: Hucitec, 1993.

BARBOSA, A. M. Arte-Educação no Brasil: realidade hoje e expectativas futuras. . Acessado em http://www.scielo.br, 1989.

BARRADAS, I. A experiência das Oficinas Humano-Mar / Abaeté. , 2009, Março 14.

BEANE, J.; APPLE, M. (ORGS.). Escolas Democráticas. Cortez, 1997.

BENNIS, D.; GRAVES, I. Introduction to The Directory of Democratic Education - What is democratic education? . Acessado em Abril 5, 2006, de http://www.educationrevolution.org/demschool.html, 1996.

BLANCO, M. A experiência do Observatório de Favelas. , 2009, Março 13.

BRANDÃO, A. T. M. Dos princípios - uma didática da invenção. . Acessado em www.aic.org.br.

BRANDÃO, C. R. Pesquisa Participante. São Paulo: Brasiliense, 1981. 
(ORG.). Repensando a Pesquisa Participante. Brasiliense, 1999.

BREMER, J. \&. M. V. M. A Revolução pedagógica: Escola sem Muros. São Paulo: IBRASA, 1975.

CARDOSO, F. A experiência do Cinemaneiro., 2008.

CARVALHOSA, Z. A experiência das Oficinas Kinoforum. , 2009, Dezembro 2.

CIPOLINI, A. Não é fita, é fato. Tensões entre instrumento e objeto. Mestrado, São Paulo. Acessado em http://www.teses.usp.br/teses/disponiveis/48/48134/tde12062008-144359, 2007.

CODELLO, F. A Boa Educação - Volume I - Experiências libertárias e teorias anarquistas na Europa, de Godwin a Neill. İcone, 2007.

COTA, G. Cinema de Quebrada leva inclusão audiovisual à periferia. . Acessado em http://www.vidauniversitaria.com.br/blog/?p=15078.

Cinema De Quebrada Oficinas Audiovisuais Na Periferia Paulistana E Seus Desdobramentos. São Paulo, 2008.

FERREIRA, A. B. D. H. Novo Aurélio - O dicionário da língua portuguesa. Rio de Janeiro: Nova Fronteira, 1999.

FIABANE, D. A experiência da Associação Imagem Comunitária. , 2009.

FILÉ, V. Fazendo causo dos causos. . Acessado em www.aic.org.br.

Os dois lados da câmera. . Acessado em www.aic.com.br.

. Sobre Produção Colaborativa. . Acessado em www.aic.com.br.

. (. O tamanho do mundo. In: Batuques, Fragmentações e Fluxos. Rio de Janeiro:

DP\&A. Acessado em Maio 16, 2009, , 2000.

FOUCAULT, M. Vigiar e Punir. Rio de Janeiro: Vozes, 2008.

FREINET, C. O Jornal Escolar. São Paulo: Martins Fontes, 1974.

. A educação do trabalho. $1^{\text {o }}$ ed. São Paulo: Msrtins Fontes, 1998.

Pedagogia do Bom Senso. São Paulo: Martins Fontes, 2000. 
. A paixão de conhecer o mundo. São Paulo: Vozes, 1989.

. Extensão ou comunicação. Rio de Janeiro: Paz e Terra, 1969.

Pedagogia da Autonomia. Paz e Terra, 1989.

A Pedagogia da Esperança. São Paulo: Paz e Terra, 1997.

Pedagogia do Oprimido. Rio de Janeiro: Paz e Terra, 2005.

FREIRE, P.; GUIMARÃES, S. Sobre Educação (Diálogos). v. 1. Rio de Janeiro: Paz e Terra, 1982.

GALLO, S. Deleuze e a Educação. Belo Horizonte: Autêntica, 2008.

GARDNER, H. Estruturas da Mente: A Teoria das Inteligências Múltiplas. Porto Alegre: Artes Médicas, 1994.

HEFFNER, H. Retrato do artista quando jovem. . Acessado em Julho 23, 2009, de enviado via email, 2009.

HITCHCOCK, A.; TRUFFAUT, F. Entrevistas. São Paulo: Brasiliense, 1986.

ILLICH, I. Sociedade sem escolas. Petrópolis: Vozes, 1974.

INCONTRI, D. Tolstoi e a Anti-Pedagogia: uma proposta de educação libertária. São Paulo, 1991.

JODOROWSKI, A. JODOROWSKY E A ESTÉTICA DA ILUMINAÇÃO. . Acessado em Fevereiro 15, 2009, de http://www.contracampo.com.br/90/artjodoiluminacao.htm, 1973a, Junho 15.

KIMO, P.; OLIVEIRA, R. F. C. D.; SANTOS, V. D. D.; RABELO, F. L. F.; CELESTINO, J. A experiência da Oficina de Imagens. , 2009, Maio 8.

KORCZAK, J. Quando eu voltar a ser criança. São Paulo: Summus, 1981.

. Como amar uma criança. Rio de Janeiro: Paz e Terra, 1983.

LEMINSKI, P. Guerra dentro da gente. São Paulo: Scipione, 2002.

LIMA, A. Projeto Educacional. 
LIMA, R. Beirando a Linha do que Já Existe - A Tv Comunitária entre os paradigmas epistemológico e praxeológico. Belo Horizonte. Acessado em Junho 25, 2009, de http://www.aic.org.br/metodologia/discussao_tv_comunitaria_e_paradigmas_teoricos_da_co municacao.pdf, 1997.

Mídias comunitárias, juventude e cidadania. Belo Horizonte: Autêntica. Acessado em Junho 25, 2009, , 2006.

LOURENÇO, T.; FELIPE, D.; MIRATI, C.; ET AL. A experiência do Cinema Nosso (visão dos alunos). , 2009, Março 17.

MACHADO, M. A experiência do Cinema Nosso. , 2009, Março 17.

MAURÍCIO, C. A experiência do Favela é isso aí. , 2009, Maio 8.

MEDEIROS, J. A experiência do Cinemaneiro, Boca de Filme, Cidadela e Oficinas HumanoMar. , 2009, Março 13.

MELO, A. A experiência da Associação Imagem Comunitária., 2009, Maio 11.

MOHALlEM, G. A experiência da Associação Imagem Comunitária. , 2009, Julho 12.

NEILL, A. S. Liberdade na escola. São Paulo, 1972.

Liberdade, escola, amor e juventude. São Paulo, 1972.

Liberdade sem excesso. São Paulo: IBRASA, 1976.

Um mestre contra o mundo: o fracasso que floriu numa nova escola. São Paulo: IBRASA, 1978.

Liberdade no lar: problemas da família. São Paulo, 1972.

Liberdade sem medo: Summerhill - Radical transformação na teoria e na prática da educação. São Paulo: IBRASA, 1984.

OLIVEIRA, N. S. D.; (NÃO INFORMOU SOBRENOME), N.; (NÃO INFORMOU SOBRENOME), E. A experiência da TV Morrinho. , 2009, Março 14.

OLIVEIRA, R. D. D.; OLIVEIRA, M. D. D. Pesquisa Social e Ação Educativa: Conhecer a realidade para poder transformá-la. In: PESQUISA PARTICIPANTE. São Paulo: Brasiliense, 1981.

PACHECO, J. Quando eu for grande quero ir à Primavera. São Paulo: Suplegraf, 2004.

PACHECO, J. Escola da Ponte - Formação e Transformação da Educação. Petrópolis: Vozes, 2006.

PASSOS, H. A experiência do BH Cidadania., 2009, Maio 8. 
PERRENOUD, P. 10 Novas Competências para ensinar. Porto Alegre: ArtMed, 1999.

. Avaliação: da excelência à regulação das aprendizagens - entre duas lógicas. Porto Alegre: ArtMed, 1999.

RANCIÉRE, J. O mestre ignorante: cinco lições sobre a emancipação intelectual.

READHEAD, Z. Summerhill Today., 2003.

REIS, M. Como nasce um Cineasta? Trabalho de Conclusão de Curso - Universitário, Niterói, 2007.

ROBALINHO, R.; LUIS, J. (.; COELHO, M. A experiência do Alice, Prepara o gato! , 2009, Março 16.

ROSATELLI, A. L. C. Ateliê de Vídeo e cultura juvenil. Acessado em http://www.teses.usp.br/teses/disponiveis/48/48134/tde-25062007-111552, 2007.

SAINT-EXUPÉRY, A. O pequeno príncipe. Rio de Janeiro: Agir, 1989.

SANTORO, L. F. A Imagem em suas mãos. Summus, 1989.

SANTOS, B. D. S. A Gramática do Tempo. São Paulo: Cortez, 2006.

SANTOS, C. A experiência da Associação Imagem Comunitária., 2009, Maio 11.

SAYAD, A. L. V. Museu de Novidades. In: EDUCOMUNICAR - Comunicação, Educação e Participação para uma educação pública de qualidade. Rede Cep de Educomunicadores.

SEMLER, R.; DIMENSTEIN, G.; GOMES DA COSTA, A. C. Escola sem sala de aula. Campinas, SP: Papirus, 2004.

SERRA, C. A experiência da TV Morrinho. , 2009, Março 14.

SILVA, L. R. A formação em cinema em instituições de ensino superior brasileiras. São Paulo, 2004a.

SILVA, L. R. A Formação em Cinema em Instituições de Ensino Superior Brasileiras. Mestrado, São Paulo, 2004.

SINGER, H. República de Crianças: sobre experiências escolares de resistência. São Paulo, 1997.

SOARES, D. Educomunicação - O que é isto? . Acessado em Junho 15, 2008, de http://www.portalgens.com.br/baixararquivos/textos/educomunicacao_o_que_e_isto.p df.

SOARES, I. Educomunicação: a contribuição que a Rede CEP pode oferecer às políticas 
públicas. In: EDUCOMUNICAR - Comunicação, Educação e Participação para uma educação pública de qualidade. Rede Cep de Educomunicadores.

TOLSTÓI, L. Obras Pedagógicas. Edições Progresso, 1988.

VALENTE, E. N. Cinema universitário : trajetórias em desenvolvimento: os filmes e o curso de cinema da ECA-USP nos anos 90. São Paulo, 2005.

VILAÇA, S. H. C. Inclusão Audiovisual através do cinema de animação". Mestrado, Belo Horizonte. Acessado em www.bibliotecadigital.ufmg.br/dspace/bitstream/1843/VPQZ73GJ4G/1/disserta_o_sergio_vilaca.pdf, 2006. 


\section{APÊNDICE A - Alunos entrevistados via questionário on- line}

a) ASSAOC - Associação de amigos das Oficinas Culturais do Estado de SP (1 aluno)

Heitor Franulovic Alcantara Pauferro

b) Oficinas Ouroboros Cinema e Educação (4 alunos)

- Fabio Luiz Silva de Oliveira

-Thiago Meira dos Santos Mouro

- Eduardo Luis de Abreu

- Jorgina Alexandra Mikita Pawlak

c) Instituto Criar de TV Cinema (32 alunos, sendo 1 anônimo)

- Luciene B Gomes

- Delvani Soares da Silva

- Paulo Eduardo Santos

- Silmara Elis de Deus Simão de Sousa

- Tiago Eli RIbeiro

- Francinaldo Lemos da Silva

- Rodrigo Santos Sousa

- Cristiano Alves da Silva

- Tiago Oliveira

- Thais Barreto Silva

- Lidiane Xavier dos Santos

- Karoline Cristina F Dos Santos

- Érika de Fátima Macedo

- Jeferson Barbosa da Silva

- Domenica Soares Perretti

- Erika Kis Rehem Dos Santos 
- André Luís Santos Duarte

- Adilma Cristina

- Rafael dos reis

- Nathany Nayara Lopes

- Tiago Miranda Ribeiro

- Jonathan Carvalho

- Tatiane De Jesus Dos Santos

- Marta Marcelino Teles Silva

- Wesley José Pereira da Silva

- Maria Amanda dos Santos

- Wesley Oliveira Lima

- Raillane Oliveira Guimarães

- Rafael Dias

- Mayara

- Natália Wandel

d) CUFA - Central única das Favelas - Rio de Janeiro / RJ (4 alunos)

- Ju (não inseriu sobrenome)

- Alexandre Botelho

- Ventolidio José de Almeida Neto

- Roberto Paulo de Albuquerque Barbosa

e) ELCV - Escola Livre de Cinema e Vídeo de Santo André/SP (5 alunos)

- Leonardo C. Gusmão

- Luma Reis

- Fausto André dos Santos

- Wesley Moreira de Andrade

- Danilo Carrera Misael e Silva

f) FUNDAÇÃO CRIANÇA - São Bernardo do Campo/SP (1 aluno) 
- Natalia Bueno Barbosa Fundação Criança

g) Geração Futura - Rio de Janeiro/RJ (21 alunos)

-Pedro Henrique da Silva Filgueira

- Marcos nascimento

- Carol Brasil

- Fabiano Fernandes Lage de Oliveira

- Lívia de Lima Agra

- Adriana Carneiro

- Wildes Sampaio

- Andressa Fernandes

- Evellyn Moreira Pacheco

- Michel Mosso Schettert

- Marianne Fonseca

- Renata Barros de Santana

- Karine Medeiros barros

- Rayssa Ávila do Valle

- Carla Festucci

- Eduarda Vieira Santos

- Nathália Dielú N. de Albuquerque

- Fabiano Lucas Fernandes

- Vinícius Gouveia

- Cristiana Fernandes de Souza

- Flávia Naiara Tabosa Pinheiro

h) JAMAC - São Paulo/SP (2 alunos)

- Thomas Germain Adiang Assoue

- Thaisa Helena de Oliveira

i) KINOFORUM - São Paulo/SP (6 alunos, sendo 2 anônimos)

- Wagner Klebson de Sousa 
- Márcio Jose Moreno

- Noel Gomes de Brito Filho

- Vanessa Reis

j) KINOOLHO - Rio Claro/ SP (1 aluno)

- Fernanda Tosini

k) OLHAR CIRCULAR ${ }^{98}$ - Maceió/AL (1 aluno)

- Govinda Maya Millan

1) OLHO VIVO - Curitiba/ PR (1 aluno)

- Maycon Santos

m) VÁRIOS PROJETOS (3 alunos)

- Kaliane Nunes Leonardo da Silva

- Caroline Silva Souza

- Ricardo Vieira de Oliveira

${ }^{98}$ Não participou do mapeamento. 


\section{ANEXO A - Lista total de 113 entidades mapeadas}

Informações completas de contato com cada uma delas serão disponibilizadas, em 2011, em um subsite especialmente dedicado à esta tese dentro do site $\underline{\text { www.kinooikos.com }}$

37 Festival de Inverno da UFMG

Abaeté Estudos Socioambientais

Ação Educativa

Afroreggae

Aldeia - Agência de Desenvolvimento Cultural, Educomunicação, Infoinclusão e Audiovisual

Aldeia do Futuro

Am FilmesDigitais

Amacine Futuro Cineastas

Animamundi

Anthares Multimeios

Arrastão

Associação Amigos das Oficinas Culturais do Estado de São Paulo

Associação Artística Saudáveis Subversivos

Associação Casa da Videira

Associação Civil Favela é isso aí

Associação Cultural Faísca

Associação Cultural Kinoforum

Associação Cultural Projeto Perifa

Associação Filmes de Quintal

Associação Imagem Comunitária (AIC)

Associação Minuto

Associação Novolhar

Ateliêr de Arte da Casa do Zezinho

Bem TV

Boteco Cinematográfico LTDA / Cooperativa de Cinema Fora do Eixo

Buriti Filmes 
Cabra Quente Filmes

Campus Avançado

Canal Futura / Fundação Roberto Marinho

Casa da Árvore Projetos Sociais

Casa de Cultura Tainã

Catavídeo

Central Única das Favelas

Centro Cultural Caieiras (Cecaes)

Centro de Comunicação e Cultura Popular Olho da Rua

Centro de Criação de Imagem Popular (Cecip)

Centro de Cultura e Estudos Superiores Aúthos Pagano

Centro de Estudos e Ações Solidárioas da Maré

Centro de Estudos Raízes do Côncavo

Centro de Referência da Juventude

Centro Estadual de Educação Técnica "Vasco Coutinho" - ES

Cidade Escola Aprendiz

Cidadela - Arte, Cultura e Cidadania

Cine Guandu

Cineclube Consciência

Cineduc - Cinema e Educação

CIPÓ - Comunicação Interativa / Oi Futuro

Ciranda

Coletivo Anti Cinema

Coletivo CineEsquemaNovo

Coletivo Filmagens Periféricas

Coordenação de Cinema, Vídeo e Fotografia da Secretaria Municipal da Cultura de Porto Alegre

ECOAR/ Rede Rocinha.com (RJ)

Empresa de Multimeios da Prefeitura do Rio de Janeiro

Escola Audiovisual Cinema Nosso

Escola Livre de Cinema de Nova Iguaçu

Escola Sesc de Ensino Médio

Fabicine / CA.GE.BE / VRAS 77 
Fábrica de Imagens

Fábrica do Futuro

Fábrica do Futuro

Faculdades Integradas Hélio Afonso

Fora da Lei

Formação (ONG)

Fundação Criança de São Bernardo do Campo

Fundação Municipal de Cultura de Belo Horizonte / Programa BH Cidadania

Giral - Informática, Comunicação e Ação Local

Grupo Ecológico e Cultural Tio Pac

Grupo Kino-Olho

Grupo Mundo Cultural

IDEIA - Instituto de Desenvolvimento, Estudo e Integração pela Animação

Image Magica

Imagem na Ação - núcleo de desenvolvimento de projetos de comunicação e

cidadania

Imagens Cruzadas

Imaginário Digital

Instituto Acaia

Instituto Criar de TV, Cinema e Novas Mídias

Instituto de Arte e Cultura Garatuja

Instituto Magneto Cultural

Instituto Nacional de Educação de Surdos

Instituto Nômades

Instituto Oficinas Querô

ITEC- Instituto Técnico de Estudos Cinematográficos

Jardim Miriam Arte Clube - JAMAC

Kinoarte - Instituto de Cinema e Vídeo de Londrina

Luz, Câmera, Ação e Esperança na vida

Mostra Paraty de Cinema -

Movimento do Vídeo Popular

Nós do Morro

Nossa Tela 
Núcleo de Arte Grécia

Núcleo de produção ARROZ FEIJÃO CINEMA E VÍDEO

Observatório de Favelas

Oficina de Imagens - Comunicação e Educação

Oficina do Parque Ponto de Cultura

Oi Kabum - Escola de Arte e Tecnologia (Spectaculu)

ONG Verde Cidadania

Organização Neo Humanitarismo Universalista

Ouroboros Cinema e Educação

PAC_Pro-Apoio Comunitario

Ponto de Cultura 'Alice, prepara o gato!'

Prefeitura Municipal de Santo André, Escola Livre de Cinema e Vídeo

Programa Habitar Brasil - BID - Prefeitura Municipal de Belo Horizonte

Projeto Cala-boca já morreu

Projeto Cine Escola, Associação Bominfa

Projeto Curta Cultura São Paulo

Projeto Graffiti com Pipoca

Projeto Olho Vivo

SESC CARMO

TV Morrinho

UEVOM - União Esportiva Vila Olimpica da Maré

UNAS União de Núcleos Associações e Sociedades de Moradores de Heliópolis e São João Clímaco

Vídeo nas Aldeias 
ANEXO B - Carta da Maré99

\section{Carta da Maré}

Nos últimos cinco anos, em todas as regiões do Brasil houve uma ampliação de experiências de formação audiovisual ligadas aos espaços populares. Esse crescimento evidenciou a necessidade de encontro e diálogo para identificar estratégias de fortalecimento dessas iniciativas, possibilitar a troca de experiências e dar visibilidade a essa diversidade de olhares.

A periferia se representa pela multiplicidade de olhares diferenciados sobre sua história, memórias e tradições, sobre a vida e a experiência das pessoas, sobre aspectos poéticos e sutis que lá encontram sobre o outro lado dos fatos e da notícia e sobre a crítica à maneira como a mídia convencional mostra as coisas. Entendendo periferia como representações próprias, que podem se colocar como um contraponto à visão imposta pela mídia convencional - que revela esses lugares como violentos e separados do resto da sociedade - caso conquistem espaços de exibição públicos, ampliando seu alcance.

Não existe, de forma alguma, uma representação da periferia a partir dos que lá estão produzindo, mas muitas e diferenciadas representações, todas válidas e necessárias para o grupo que se expressa. O principal na diversidade das produções audiovisuais brasileiras, tal como em qualquer produção artística, é o que leva a pensar, tanto quem cria, como quem assiste.

A Carta da Maré sai do Primeiro Fórum de Experiências Populares em Audiovisual que aconteceu no dia 09 de junho de 2007, no Rio de Janeiro, dentro da programação do Festival Visões Periféricas. O encontro reuniu 42 iniciativas de um universo estimado em cerca de 200 grupos que desenvolvem trabalhos na área do audiovisual. O Fórum evidenciou a necessidade de um reconhecimento público dessas

\footnotetext{
${ }^{99}$ Obs: O Fórum de Experiências Populares em Audiovisual, que deu origem à carta, aconteceu dentro do Festival Audiovisual Visões Periféricas realizado no Rio do dia 06 a 17 de Junho de 2007 e reuniu produtores, realizadores e instituições de formação audiovisual das periferias de todo o Brasil.
} 
produções periféricas, bem como adequações das políticas públicas para essas expressões populares. Assim, escrevemos essa Carta Aberta ao Ministério da Cultura com nossas propostas sobre os temas formação, produção e difusão do audiovisual pelo Brasil.

\section{PROPOSTAS}

1. Alterar a política de financiamento, distribuição e exibição das produções, para que o audiovisual popular possa ser amplamente divulgado, possibilitando à sociedade contato com outras visões, diferentes das que assistem diariamente em filmes, programas de tv e noticiários;

2. Criar editais públicos adequados aos núcleos populares (ong`s, oscips, coletivos, etc...) de formação audiovisual com dotação orçamentária específica para cada região do Brasil (regionalização da produção). Esses editais devem promover a diversidade sócio-cultural de cada região. Para isso, propomos um diálogo com as instituições que desenvolvem trabalho nessa área, de modo a que se considere a importância dos processos educativos, as especificidades dos grupos/sujeitos, a continuidade e sustentabilidade das ações, os critérios de avaliação, a distribuição dos produtos, etc;

3. Demarcar a TV pública e a Programadora Brasil como espaços para divulgação das produções periféricas, democratizando o seu perfil e imprimindo uma visão regional;

4. Reivindicar contrapartidas das TV`s públicas e comerciais no sentido de coproduzir obras a partir dos núcleos populares de formação audiovisual;

5. Incentivar a formação de platéias para o que é produzido pelos núcleos populares de formação audiovisual através dos cineclubes, escolas e espaços de exibição alternativos, festivais e mostras;

6. Apoiar o Fórum de Experiências Populares em Audiovisual (FEPA), no 
sentido de torná-lo uma atividade itinerante, representado em diferentes eventos de audiovisual do país;

7. Criar um espaço de discussão para se pensar uma política de educação audiovisual, de modo a agregar os conteúdos e linguagens do audiovisual na escola, a partir de diferentes modos: formação de professores, disciplina própria, atividades complementares, tema transversal, oficinas, gerenciamento de equipamentos, utilização do audiovisual como instrumento pedagógico etc;

8. Fomento à integração das universidades públicas, as instituições de comunicação comunitária e o poder público, de modo a estimular pesquisas e o desenvolvimento de ações, especialmente no campo da formação de comunicadores e educadores.

9. Contribuição na construção de um portal nacional com produções audiovisuais que saíram de oficinas e projetos afins com o público de periferia.

10. Desenvolver uma política de educação audiovisual, de modo a agregar os conteúdos e linguagens do audiovisual na escola, a partir de diferentes modos: formação de professores, disciplina própria, atividades complementares, tema transversal, oficinas, gerenciamento de equipamentos, etc

Rio de Janeiro, 10 de Junho de 2007

Assinam esta carta as seguintes instituições e coletivos;

Observatório de Favelas/RJ, Cinema Nosso /RJ, TV Morrinho /RJ, Ascine / RJ, ABD\&C / RJ, Cinemaneiro /RJ, Bem TV/RJ, Rede Jovem de Cidadania (Associação Imagem Comunitária) /MG, Juventude de Atitude (Associação de Imagem Comunitária) /MG, Favela é isso aí / MG, Kinoarte -Londrina /PR, Associação Quilombola de Conceição das Crioulas-PR, Movimento Cultural Arte e Manhã - Caravelas /BA, Auçuba - Comunicação e Educação- Recife /PE, Vídeo nas Aldeias-Rio Branco/AC, Festival Um Amazonas /AM, Amacine Futuros Cineastas / 
AM, Ação Jovem Indígena /MS, Anthares Multimeios /SP, Associação Kinoforum /SP, Cinema de Guerrilha / SP, Instituto Criar de TV e Cinema /SP, Ong Ação social Pankararú /SP, Aldeia-Fortaleza /CE, Associação Cultural Faísca -Riacho Fundo/ DH, Centro de Referência Undergrond-DH, Rede terceiro Setor /RJ, UFRJ /RJ, Oficina de Imagem/RJ.

Estavam presentes no Fórum e na construção desta carta:

Fabiana Santos, Douglas dos Santos, Anderson Craveiro, Kelly Martins Oliveira, Jacó Galdino, César Maurício, William Alves, Franklin Costa, Michela Albuquerque, Junior Rodrigues, Danielle Almeida, Martinho Mendes, Carlos R.S.Moreira, Dario Gularte, Alcir R. Medina, Antônio João Rodrigues, Paulo Júnior Rodrigues, Vicent Carelly, Sérgio José de Andrade, Marilisse Navarro, Josias Pereira, Maná Kuirikui,Michel Brasil, Érika Macedo, Bruno Vilela, Rodrigo Bouillet, Gianni Puzzo, Christian Saaghard, Francisco, Rodrigo Grota, Fabio Camareiro, Fernando Rodrigues Frias, Gorete Linhares,Mariane Barros, Alexandre Bortoline, Fabio Diaz, Erica Macedo, Maria Daniele Macedo, Gabriel Bortoline, Frederico Cardoso, Daniela Araújo, Regina Bortoline, Tereza Brant, Mercia Britto, Kelly Russo, Marcio Blanco, Bernard Brant, entre outros.

Organização:

Idealização do fórum: Marcio Blanco

Coordenação do fórum : Mércia Britto

Mediadores dos grupos de trabalho: Marilisse Navarro, Liliane Lerox, Regina Bortoline, Kelly Russo e Winston .

Produção: Mariângela Carvalho 


\section{ANEXO C - Carta de saída do Cinema Nosso}

Rio de Janeiro, 19 de janeiro de 2009.

PREZADOS COMPANHEIROS E COMPANHEIRAS:

Primeiramente desculpem-nos pela demora em nosso posicionamento. Durante toda história do Cinema Nosso, sempre nos propusemos a dialogar com os diversos setores da sociedade no sentido de fomentar a troca de experiências e conhecimentos para o aperfeiçoamento das atuações isoladas e coletivas, assim como colaborar para a construção de políticas publicas mais efetivas na área de Educação e Cultura. Desta forma, vislumbrávamos, em setembro de 2008, que o Fórum de Experiências Populares em Audiovisual (FEPA) poderia se constituir como espaço privilegiado para a troca de informações relevantes e estímulo para a cooperação entre organizações não governamentais, instituições públicas e privadas, coletivos e projetos sociais que almejam a construção de propostas democráticas para o audiovisual.

Estamos cientes de que a articulação de um fórum não é tarefa fácil e que demanda muito empenho, paciência e sensibilidade para lidar com as diferenças de pensamento e formas de atuar de seus diversos integrantes. O Cinema Nosso reconhece que nem sempre foi tão presente nas discussões na internet, porém procuramos sempre participar ativamente de todos os encontros presenciais promovidos pelo fórum, inclusive, dois dos nossos representantes assumiram grupos de trabalhos no último encontro - Políticas Públicas e Organização do Fórum , na tentativa de contribuir, na medida do possível, para o fortalecimento dessa iniciativa, ainda que não concordássemos com todos os encaminhamentos e propostas.

No entanto, a última reunião presencial do FEPA, realizada durante o Festival Visões Periféricas, e os últimos e-mails que acompanhamos revelaram que o Fórum caminha para uma direção que o Cinema Nosso não acredita ser a mais adequada para o fortalecimento de um movimento nacional pela democratização do audiovisual. 
Há alguns anos o Cinema Nosso fundou e faz parte de uma rede de cinema popular na América Latina com representantes de outros nove países, além do Brasil. Os motivos que nos levaram a fundar, com outras organizações, essa rede latina foram os mesmos que nos fizeram ingressar no FEPA: a vontade de conhecer, intercambiar e trocar iniciativas de educação e produção de cinema com organizações, coletivos e experiências populares do audiovisual brasileiro.

Por isso, discordamos veementemente de qualquer processo de formalização do Fórum como instituição, que, em nosso entendimento, tende a reproduzir padrões mercado-lógicos ou burocráticos de atuação de grandes companhias. A denominação de cada organização como uma Experiência Popular em Audiovisual (EPA) é um exemplo de como a institucionalização tende a apagar a diversidade e a história de cada uma delas.

Um processo deliberativo a partir de representantes regionais criaria níveis de hierarquia e poder diferenciados entre as organizações participantes, tornando a tomada de decisão menos coletiva e transparente, mais verticalizada e questionável. Ressaltamos ainda o fato de que a convocatória para reunião do Conselho Consultivo da Secretaria do Audiovisual (SAV) que sucedeu o último encontro no Visões Periféricas foi incluída na lista de discussão quatro dias antes da sua realização, impedindo a participação efetiva de muitas das organizações na elaboração de uma pauta a ser debatida junto ao Governo Federal. Consideramos esse episódio um retrocesso frente ao processo coletivo e democrático vivenciado e demandado pelas organizações durante o último encontro presencial do Fórum. O Cinema Nosso não concorda com o fato de que os representantes do FEPA, sejam eles quem forem, possam estabelecer um diálogo direto com o setor público e encaminhar propostas que as organizações, coletivos e experiências populares "representados" pouco conhecem ou desconhecem totalmente. A participação deve estar garantida por mecanismos claros e acessíveis a todos.

Pelas razões acima expostas, o Cinema Nosso comunica oficialmente sua retirada do Fórum de Experiências Popular em Audiovisual (FEPA) e a saída dos seus 
representantes dos grupos de trabalho. Continuamos dispostos a fomentar os laços de cooperação e a troca de informações e práticas educativas com outras organizações, coletivos e experiências populares em audiovisual que estejam em sintonia com a nossa filosofia.

Atenciosamente,

Alex Nascimento Barreto

Secretário Executivo

www.cinemanosso.org.br

21-2505-33-00 


\title{
ANEXO D - Carta de saída do Coletivo de Vídeo Popular
}

\author{
Carta de Posicionamento e desligamento do Fórum de Experiências \\ Populares em Audiovisual - FEPA
}

A todos os interessados no audiovisual popular:

Escrevemos essa carta para tornar público nosso posicionamento e desligamento do Fórum de Experiências Populares em Audiovisual. Em primeiro lugar é importante deixar claro o quanto acreditamos na importância de iniciativas de se construir um fórum, que deve ser um espaço de troca de idéias, experiências e construção de pautas, demandas, diagnósticos acerca do audiovisual popular, e, portanto, com participação dos realizadores audiovisuais realmente populares, sejam exibidores, formadores, produtores e/ou distribuidores.

Ingressamos no FEPA justamente interessados em nos inteirar das discussões, acreditando que poderíamos colaborar com uma construção coletiva. Consideramos fundamental a idéia de um espaço no qual fossem levantadas e discutidas as propostas de um movimento, com e pelos seus autores sociais. Isso, com ênfase na participação, na colaboração e na transparência.

Em sintonia com a nota divulgada pelo Cinema Nosso em janeiro deste ano, não concordamos com a forma atual de representação estabelecida no FEPA, onde propostas são encaminhadas sem que tenham sido amplamente debatidas com seus integrantes.

Acreditamos que o vídeo popular é um trabalho que se estabelece na base com uma atuação social marcada por seus próprios atores. Nossa realidade não pode ser homogeneizada e transformada em uma única Organização com um representante institucional.

Nesta linha estamos priorizando o fortalecimento dos trabalhos nas 
comunidades e para isto estamos construindo um Circuito de Exibição de Vídeo Popular que conta hoje com 20 pontos de exibições, 40 filmes, envolvendo aproximadamente 40 coletivos e ou grupos organizados que trabalham com vídeo popular. Além do circuito, produzimos uma revista do Vídeo Popular e em setembro acontecerá a $3^{\mathrm{a}}$ Semana do Vídeo Popular.

\section{COLETIVO DE VÍDEO POPULAR}

http://coletivovideopopular.blogspot.com/

videopopular@gmail.com

Assinam esta carta:

Ação Educativa, Arroz Feijão Cinema e Vídeo, CarlosCarlos - CNSA, Cia Estudo de Cena, Cine CRUSP, CineBecos, CineCampinho, Cineclube Polis / Instituto Polis, FABICINE - CineEscadão, Fanzine Catraca, Fernando Frias, Filmagens Periféricas, Lunetim Mágico - vídeo Independente, MUCCA, Mundo em Foco, NCA, Nossa Tela, Vanessa Reis 


\section{ANEXO E - Carta de saída da Kinoforum}

Caros,

A Kinoforum aprecia e integrará sempre um saudável debate entre todos que se interessam e atuam em prol do audiovisual popular. Acreditamos que fóruns são espaços privilegiados para o debate, a troca, a criação coletiva e o desenvolvimento de propostas para o setor - sempre partindo das demandas específicas de seus atores.

É nesse sentido que apostamos no potencial do FEPA, quando do seu surgimento, como uma rede integrando diferentes atores sociais em busca de objetivos comuns. Não acreditamos no FEPA como entidade representativa do audiovisual popular. O próprio debate sobre a representação tomou um precioso tempo que poderia ter sido direcionado a outros assuntos, afastou pessoas e grupos, e esvaziou o movimento e a lista. Acreditamos que seria melhor que o FEPA fosse, em todos os sentidos, tão somente um fórum livre de reflexão. O que infelizmente não vem ocorrendo.

Estamos sempre abertos ao diálogo, mas somos contra esse estado de coisas que tornou o FEPA, formal ou informalmente, um agente representativo sem uma real interlocução entre as bases. O FEPA, se colocando com representante de um todo - todo esse ainda em construção -, acaba refletindo um direcionamento insuficientemente identificado com os interesses dos diversos atores sociais envolvidos.

Dessa forma, em plena concordância com os demais argumentos do Cinema Nosso e da carta de desligamento do Coletivo de Video Popular de São Paulo, a Kinoforum vem comunicar seu desligamento do FEPA.

Para dar sequência ao debate, convidamos a todos para participar do 8 Encontro KinoOikos Formação do Olhar, a realizar-se na $20^{\mathrm{a}}$ edição do Festival Internacional de Curtas de São Paulo, no dia 22 de agosto, na Cinemateca Brasileira - 
Sala Petrobras, das $14 \mathrm{~h}$ às $18 \mathrm{~h}$. A temática proposta para esse encontro são as fronteiras e desdobramentos das iniciativas de formação audiovisual em projetos sociais; a formação de coletivos audiovisuais, as diversas trajetórias e as consequiências dessas iniciativas, assim como seus espaços e políticas públicas específicos.

Atenciosamente,

Zita Carvalhosa

Associação Cultural Kinoforum 


\section{ANEXO F - Carta resposta do FEPA à saída dos grupos}

\section{EDUCAR OU DESEDUCAR?}

Em relação às experiências populares em audiovisual, talvez tenhamos que nos deseducar para podermos nos conectar plenamente com as diversificadas e ousadas idéias e práticas audiovisuais nos campos da formação, da produção e difusão que pululam pelos quatro cantos do Brasil em comunidades quilombolas e indígenas, entre jovens das periferias dos grandes centros, entre trabalhadores do campo e da cidade e em inúmeros outros contextos com incontáveis outros atores e atrizes que divisam no audiovisual possibilidades estéticas singulares; possibilidades reflexivas e afirmativas de suas identidades; um instrumento que dá voz a atores e atrizes e visibilidade a contextos historicamente invisíveis; que contribue nos processos de empoderamento cultural e político de sujeitos; que subverte, enfim, de algum modo, as lógicas estruturadas e estruturantes de padronização social e de exclusão, violência e anulação dos que estão à margem. Uma produção que, na maioria dos casos, rompe com os padrões e modelos de realização que já estão estabelecidos e surge como uma nova perspectiva para o audiovisual brasileiro para além da tela do cinema.

Em relação à mobilização e organização de coletivos, associações e ong's, essa questão também suscita provocações. Será que precisaremos nos educar para trabalhar coletivamente, respeitando as diferenças para nos aproximarmos pelo que temos em comum? Por que e para quê queremos e/ou precisamos nos organizar e mobilizar cada vez mais outros sujeitos? Quais são os nossos objetivos e para onde queremos caminhar?

Qual a melhor forma de organização para um fórum que se apresenta como um espaço para mobilização social e ação política? O FEPA deve almejar ser uma instância representativa do audiovisual popular? Quais as necessidades de se instituir representações? Quais os princípios que nos norteiam e quais são as nossas prioridades? Que relação desejamos manter com o Estado em todas as suas instâncias? Essas e outras questões ainda estão presentes nos que se encontraram no Festival Visões Periféricas, em julho de 2009, e que são integrantes do FEPA.

Concordamos que é necessário desenvolver formas cada vez mais 
participativas para avançarmos em questões muito mais simples que as colocadas anteriormente, inclusive. Ainda não conseguimos sequer organizar um Encontro Nacional do FEPA fora do eixo Rio de Janeiro e São Paulo. Concordamos que um fórum pode ter papel muito importante no desenvolvimento de ações coletivas, visto que nos permite estar em contato com tantos e diferentes lugares e que deve ser um espaço de troca de idéias, experiências e construção de pautas, demandas, diagnósticos acerca do audiovisual popular, e, portanto, com participação dos realizadores audiovisuais realmente populares, sejam exibidores, formadores, produtores e/ou distribuidores. Concordamos que para trazer novos participantes é necessário o fortalecimento de ações mobilizadoras nos estados, envolvendo outros indivíduos e coletivos.

Em quase três anos de existência, o FEPA alcançou resultados positivos, a partir de 03 encontros e debates em uma lista virtual: interlocução com a Secretaria de Audiovisual do Ministério da Cultura; um edital público de produção voltado exclusivamente para participantes e ex participantes de oficinas de formação em audiovisual na periferia; aproximação com outras entidades políticas do setor audiovisual; inserção em programas públicos de democratização do audiovisual; construção de um site colaborativo para servir de fonte de consulta e espaço de discussão entre as EPAS.

Contudo, avaliamos também que o período de três anos de FEPA é insuficiente para consolidarmos sua forma de organização e seus princípios. Ambos ainda estão em processo de construção. O formato de representação ainda está em debate. A forma de comunicação entre seus integrantes ainda está sendo experimentada. A fórmula para mobilizar e envolver cada vez mais sujeitos ainda não foi encontrada. Há um desejo de que todos participem e cumpram com os compromissos assumidos. É preciso uma postura participativa na construção coletiva, seja para frear o carro em alta velocidade, seja para acelerar ações que fortaleçam o movimento.

Não disputamos forças, não queremos poder, precisamos é nos mobilizar. Que todos participem e dêem uma chance à coletividade, para que o novo, o diferente dos modelos já experimentados possa nascer. Que os erros, acertos, equívocos e atropelos cometidos pela falta de maturidade do próprio movimento sejam o ponto de partida para um Fórum autônomo e independente, forte e maduro em suas proposições para a 
coletividade e para as experiências populares em audiovisual.

Durante esse processo, precisaremos nos educar ou nos deseducar?

Considerando todas essas reflexões e questões coletivas, que ainda estão em debate e construção, os coletivos, as entidades e os indivíduos presentes no último Festival Visões Periféricas fazem um chamamento àqueles que, por motivos e razões diversas, se desligaram do FEPA, para que voltem a integrar o Fórum ou a princípio retomemos nossas conversas, a fim de avaliarmos coletivamente os problemas levantados, na perspectiva de contribuir para a construção deste espaço.

Avaliamos que vivemos um momento marcado pelo pouco envolvimento dos membros do FEPA em todo o Brasil. Por isso, achamos fundamental convocar também todos os participantes deste Fórum para o desenvolvimento de um processo de avaliação geral e retomada de sua organização.

Para isso, acreditamos que a organização do Encontro Nacional do FEPABrasil seja pauta prioritária, para que juntos possamos debater o FEPA que temos e o FEPA que queremos; retomando as discussões iniciadas em 2008 (que culminaram na proposta dos GT's) e fazendo os ajustes e as reorientações que o coletivo avaliar necessárias dentro de um processo construído democraticamente.

Assinam essa carta:

Willian Alves (Associação Cultural Faísca - Brasília/DF) Karina Moura (Centro de Com. e Cultura Popular Olho da Rua - Vila Velha/ES) Marcos Rocha (Fábrica de Imagens - Fortaleza/CE) Paula Kimo (Oficina de Imagens - Belo Horizonte/MG) Jean Cardoso (Cipó Comunicação Interativa - Salvador/BA) Márcio Blanco (Imaginário Digital - Rio de Janeiro/RJ) Jaco Galdino (Movimento Cultural Arte Manha - Caravelas/BA) Paulo Rodrigues (Manaus/AM) Flávio Martins (Centro Social Futuro Feliz - Rio de Janeiro/RJ) Wertemberg Nunes (Instituto Taboka Sul, Taboka Grande - Palmas/TO) Antônio Gil (Centro de Cultura da Vila de Ponta Negra - Natal/RN) Nonato Chacon (Ponto de Cultura A Bruxa tá solta - Boa Vista/RR) José Maria (Argonautas Ambientalistas da Amazônia - Belém/PA) 


\section{ANEXO G - Uma atualização sobre as representações da}

EAP

Desde que iniciei a pesquisa e redação desta tese me afastei da "linha de frente", especialmente dos espaços coletivos como os Fóruns. Não atuo no Coletivo de Vídeo Popular, ainda que ele seja composto por alguns membros egressos do Fórum Cinema de Quebrada e diversos ex-alunos meus. Também não participei da fundação e nunca integrei pessoalmente o FEPA, ainda que tenha amizade e grande admiração por diversos projetos e entidades que ainda são por ele representados, como a Oficina de Imagens (MG) e a Oficina de Imagem Popular (DF), dentre muitos outros. Coordenei a Mostra KinoOikos formação do Olhar entre 2004 e 2008 e neste período sediamos um encontro do FEPA. Participei desta edição e, do que foi relatado aqui, foi o momento em que vi esses últimos conflitos mais de perto.

No entanto, todos esses anos venho acompanhando o desenrolar dos fatos no Festival de Curtas e em outros festivais - nos quais nos últimos anos participei em debates e palestras; nas listas de discussão da internet (do FEPA e do coletivo, que, cada uma em seu momento, já foram campos de batalha); e em inúmeros encontros informais e telefonemas em que, ao encontrar ou ligar para um profissional para dirimir dúvidas da tese, o assunto inevitavelmente resvalava no conflito FEPA/Coletivo. (Fecha parêntesis)

Pouco antes de finalizar a redação desta tese, telefonei para Márcio Blanco, para dirimir algumas dúvidas sobre os projetos em que ele atuou. E, como eu poderia ter previsto, o assunto FEPA/'Paulistas" mais uma vez veio á baila - dessa vez, tendo como foco a indicação de Vanessa para a cadeira da SAV.

Correndo o risco de me repetir - pois essa tem sido minha linha de argumentação há algum tempo - ponderei com ele que este conflito está paralisando o desenvolvimento de uma ação efetiva de troca de experiências pedagógicas e de construção coletiva de políticas públicas. Sugeri, mais uma vez que ele buscasse 
promover um diálogo franco e não bélico com representantes do Coletivo de Vídeo Popular com foco nos pontos em comum, e não nos mesmos e desgastados temas que geraram a ruptura. Insisti no fato de que Blanco, a meu ver, estaria cego pelo conflito e sendo incapaz de valorizar as impressionantes conquistas do Coletivo no sentido da representação efetiva das bases.

Blanco argumentou, com alguma razão, que independentemente de qualquer conflito histórico, haveria uma grave distorção no fato de Vanessa ser indicada - uma vez que o Coletivo de Vídeo Popular não possui representação nacional.

Mas a situação é, por fim, bastante ambígua. Vanessa - como coordenadora da Formação do Olhar - se relaciona com coordenadores, educadores e ex-alunos de todo o país. Ao longo do ano, o faz também através das listas. Tendo como referência a própria argumentação apresentada pelas entidades e pelo coletivo ao deixarem o FEPA, este ainda não pode ser considerado - de fato - uma representação nacional. $\mathrm{O}$ FEPA não possui instâncias efetivas de articulação com os projetos e com a chamada "Linha de Frente" e nesse sentido não pode-se afirmar com certeza que, com suas intenções de abrangência nacional, consiga de fato consultar e representar a todo o país - coisa que acredito estar mais próxima, nesse momento, justamente da realidade de Vanessa. 


\section{ANEXO H - Questionário - Entidades de Educação}

\section{Audiovisual Popular}

Disponível em: http://www.educacaoaudiovisual.blogspot.com/

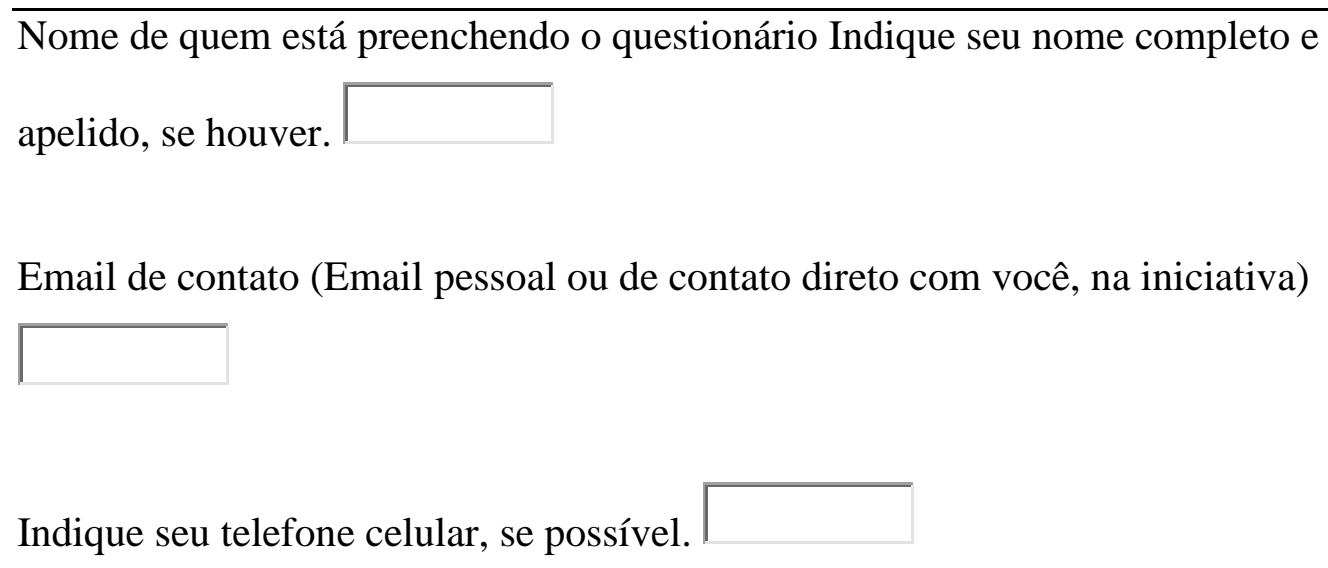

Vínculo com a Entidade Promotora

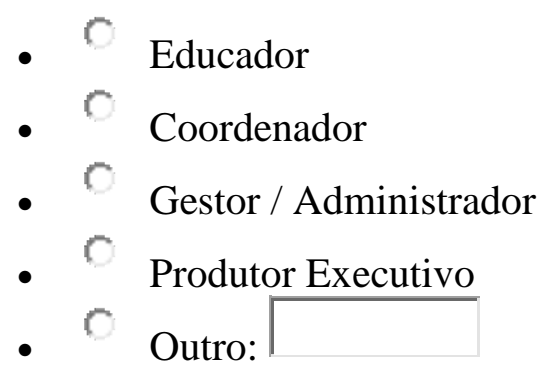

Nome da Entidade Promotora (Ex: Secretaria de Cultura de Poá, Associação Cultural do Primeiro Cinema, Coletivo Cinema Bruto, etc)

Perfil

- $\quad$ Pública (Órgãos Governamentais, Secretarias, etc)
- $\quad$ Privada, de interesse civil, sem fins-lucrativos (ONGs, Associações, etc) 
- $\quad$ Privada, com fins lucrativos. (Empresas, Produtoras de Cinema, etc)

- Iniciativa Informal

- Outro:

Endereço

Bairro

$\mathrm{CEP}$

Cidade

Estado

Email Oficial da Entidade Promotora Indique o email de contato oficial com a

Entidade Promotora

Telefones Indique os telefones da Entidade Promotora e do Projeto (Caso sejam diferentes)

Ano de Fundação da ENTIDADE PROMOTORA

Ano de Finalização das Atividades da ENTIDADE PROMOTORA Em caso de entidades já extintas.

Identifique a resposta que mais adequa-se ao caso da Entidade Promotora que você representa:

- $\quad$ Entidade Promotora integralmente dedicada à educação audiovisual 
- $\quad$ Entidade Promotora possui outras atividades e oficinas audiovisuais contínuas

- Entidade Promotora possui outras atividades e oficinas audiovisuais eventuais

- Entidade Promotora possui outras atividades e oficinas audiovisuais em evento único até agora

- $O$ Outro:

Descreva em poucas linhas o objetivo geral da Atividades da Entidade Promotora. Se houver, cite a missão/visão/valores ou texto afim.

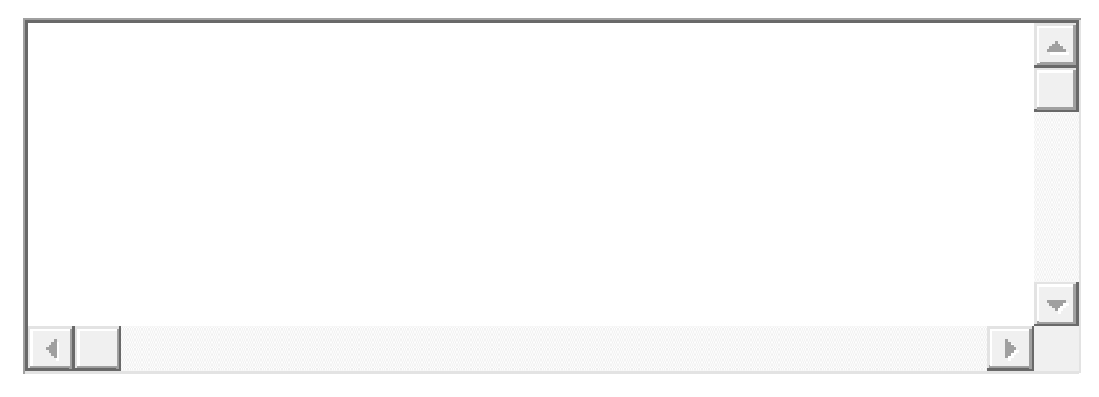

Nome do Projeto de Ensino Audiovisual Caso seja diferente do nome da Entidade Promotora. Ex: Oficina de Cinema Digital da Serrinha, Projeto Vídeo-Jovem, etc.

Ano de Início do Projeto de Ensino Audiovisual Indique caso a Iniciativa tenha dado início às atividades audiovisuais em data posterior à data de fundação da Entidade Promotora

Ano de Finalização do Projeto de ENSINO AUDIOVISUAL Caso as atividades tenham sido "eventos únicos" ou já tenham sido extintas.

Objetivo geral do Projeto de Ensino Audiovisual Selecione a resposta que mais se adeque ao perfil do Projeto.

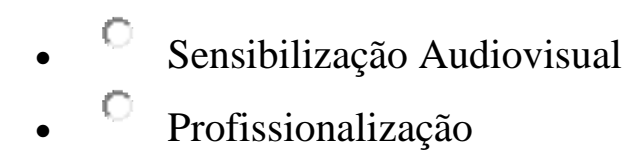


- Formação Artística/Linguagem

- $\quad$ Empreendedorismo

- Outro:

Objetivos Específicos do Projeto de Ensino Audiovisual

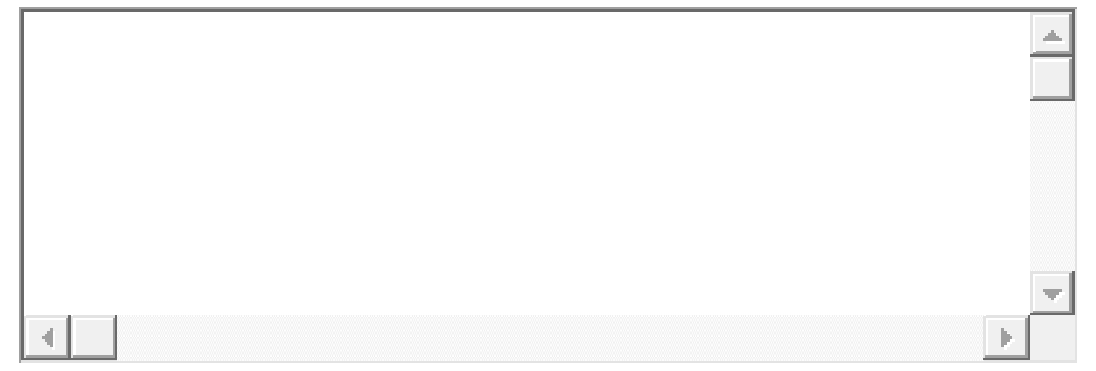

Horas/aula da atividade - por turma/ciclo. Quantas horas aula envolvendo ensino audiovisual cada turma tem, por ciclo de formação.

$\begin{array}{lll}\text { - } & \text { até } 20 \mathrm{~h} \\ \text { - } & \mathrm{C} & 20 \text { a } 80 \mathrm{~h} \\ \text { - } & \mathrm{O} & 80 \text { a } 160 \mathrm{~h} \\ \text { - } & \mathrm{O} & 160 \text { a } 400 \mathrm{~h} \\ \text { - } & \mathrm{C} & 400 \text { a } 800 \mathrm{~h} \\ \text { - } & \mathrm{O} & \text { acima de } 800 \mathrm{~h}\end{array}$

Duração Média da Formação no Projeto de Ensino Audiovisual Por turma/ciclo. Pode ser aproximado.
- 1 Semana
- 1 Mês
- 4 meses
- 6 meses
- 1 Ano
- 2 Anos
- $\mathrm{Mais}$ de dois anos.
- $\mathrm{O}$ Outro: 
O Projeto oferece algum tipo de certificado ou diploma?

- Certificado de Conclusão de Curso

- $\mathrm{D}$ DRT

- Diploma

- Carta de Recomendação

- $C$ Não Oferece.

- $\mathrm{O}$ Outro:

Como o Projeto é financiado? Se houve mudanças ao longo dos anos, cite

brevemente.

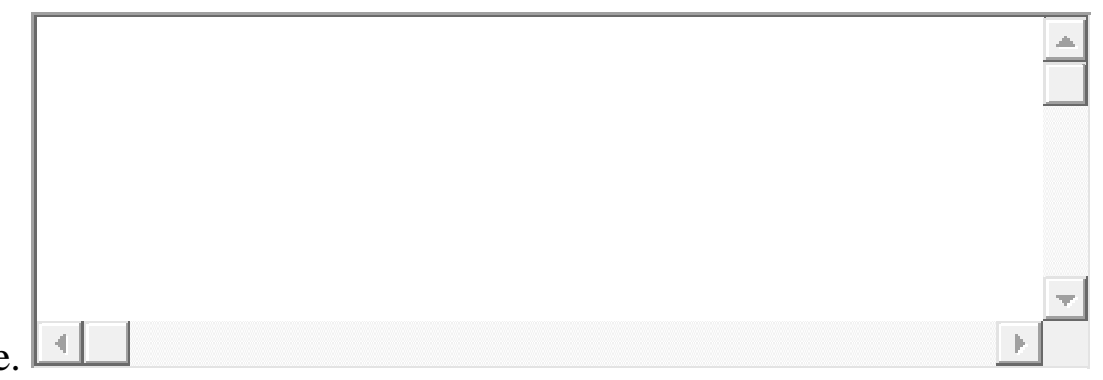

O Projeto de Educação Audiovisual possui proposta metodológica definida?

$$
\begin{array}{ll}
\text { - } & \text { Sim } \\
\text { - } & \text { Não }
\end{array}
$$

Em caso de resposta positiva à questão anterior, como você caracterizaria essa metodologia? Cite o(s) principal(is) autor(es) de referência, se houver.

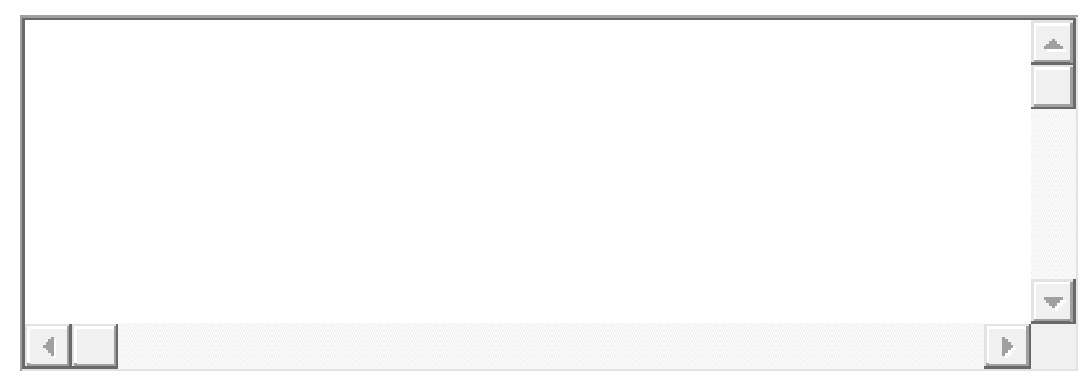

Quantos alunos o Projeto de Educação Audiovisual já formou, nos anos de atividade? 
Se não tiver um número preciso, insira uma estimativa.

Quantos vídeos já foram produzidos pelos alunos do Projeto? Se não houver um número oficial, indique um número estimado.

Algum vídeo realizado durante as atividades do Projeto foi exibido na Televisão nos últimos 12 meses??

$$
\begin{array}{ll|l}
- & \text { Sim } \\
- & & \text { Não }
\end{array}
$$

Algum vídeo realizado durante as atividades do Projeto foi exibido na televisão antes desse período?

$$
\begin{aligned}
& \text { - } \mathrm{Sim} \\
& \text { - } \mathrm{Não} \\
& \text { - A iniciativa ainda não existia. } \\
& \text { - } O \text { Outro: }
\end{aligned}
$$

Algum vídeo realizado durante as atividades do Projeto foi exibido em Festivais nos últimos 12 meses??

$$
\begin{array}{ll|l}
- & \text { Sim } \\
- & & \text { Não }
\end{array}
$$

Algum vídeo realizado durante as atividades do Projeto foi exibido em Festivais antes desse período?

$$
\begin{array}{lc|l} 
& C & \text { Sim } \\
- & \mathrm{C} & \text { Não } \\
- & \mathrm{O} & \text { A iniciativa ainda não existia. }
\end{array}
$$




\section{- $\quad$ Outro:}

Quantos alunos são formados por turma/ciclo?

Algum vídeo realizado durante as atividades do Projeto já recebeu algum prêmio?

$$
\begin{array}{ll|l}
- & \text { Sim } \\
\text { - } & \text { Não }
\end{array}
$$

Em caso de resposta positiva, cite o(s) prêmio(s) recebido(s)

O Projeto possui estratégias/ferramentas de inserção profissional para seus alunos?
- $C$ Não.
- Sim, encaminhamento para estágios e empregos.
- $\quad$ Sim, encaminhamento ou parceria com central de estágios.

Quantos ex-alunos, dentre os formandos, você estima que entrem no mercado de trabalho em atividades envolvendo audiovisual após o término do ciclo de formação do Projeto? É apenas uma estimativa.

$$
\begin{array}{lll}
\text { - } & \text { Nenhum } \\
\text { - } & \mathrm{O} & \text { Poucos } \\
\text { - } & \mathrm{C} & \text { Cerca de metade de cada turma } \\
\text { - } & \mathrm{O} & \text { Muitos } \\
\text { - } & \mathrm{C} & \text { Todos }
\end{array}
$$

Como você definiria o nível de participação dos alunos nas decisões sobre o Projeto? Especialmente durante as oficinas ou em seu planejamento. 
- Nenhum. Os alunos não participam diretamente das decisões.

- Pequeno. Eventualmente os alunos são chamados a opinar.

- Médio. Em instâncias pré-definidas os alunos opinam e participam.

- Alto. Muitas decisões são tomadas em consulta e debate com os alunos.

Sobre a existência de instâncias de Participação e Debate no Projeto. Selecione o(s) íten(s) adequado(s).

- Г Não há.

- $\Gamma$ Assembléias Coletivas.

- $\square$ Centro Acadêmico / D.A./ Nucleo Jovem ou afim.

- $\square$ Aulas/Encontros sistemáticos com a equipe pedagógica, para debater temas de interesse coletivo.

- $\square$ Fóruns Virtuais.

- $\quad$ Emails coletivos.

- $\square$ Reuniões dos alunos com a equipe de educadores.

- $\square$ Reuniões de Pais e educadores.

- $\square$ Atividades Auto-gestionadas (Concebidas e realizadas pelos alunos, no âmbito da Entidade)

- Outro:

A Entidade Promotora/Projeto tem interesse em conhecer maiores detalhes sobre a participação na segunda etapa da pesquisa? * Em caso positivo, aguarde notícias através do email indicado nesse formulário.

$$
\begin{array}{ll|l}
. & \text { Sim } \\
- & \text { Não }
\end{array}
$$

A Entidade Promotora/Projeto tem interesse em conhecer maiores detalhes sobre a participação na segunda etapa da pesquisa? * Em caso positivo, aguarde notícias através do email indicado nesse formulário. 
\begin{tabular}{ll|l} 
- & Sim \\
- & Não
\end{tabular}

Espaço livre para comentários adicionais. FIque MUITO à vontade para falar mais da sua experiência, inserir outros textos, trechos de projetos, cartas de alunos....Fique à vontade também para fazer comentários sobre o questionário.

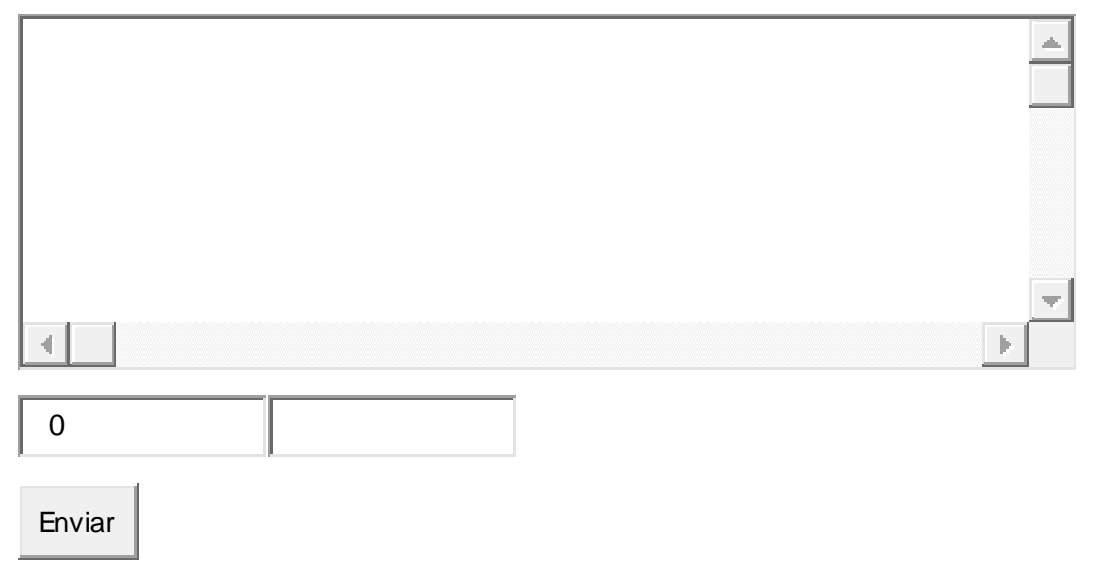

Anexo I - Questionário Coordenadores

Disponível em: http://coordenadoresaudiovisuais.blogspot.com/

*Obrigatório

Nome $* \longdiv { }$

E-mail de contato pessoal $* \longdiv { }$

Entidade $* \longdiv { }$

Projeto de Ensino Audiovisual *

Cargo que ocupa * Selecione o título que se assemelha à forma como você é creditado por suas atividades. 
- Coordenador Geral

- Coordenador Pedagógico

- $C$ Coordenador Educativo

- $O$ Outro:

O que o levou a se tornar coordenador audiovisual? Conte um pouco do seu percurso, como chegou à entidade e se preparou para sê-lo. *

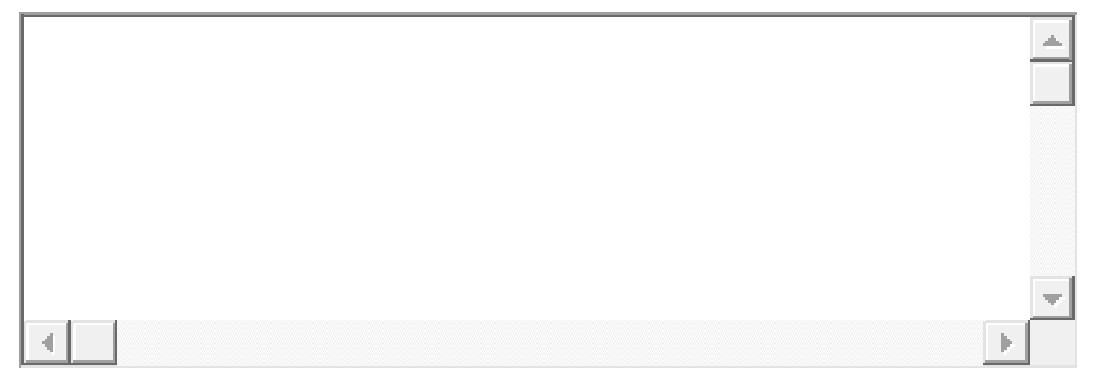

Você tem referências teóricas sobre educação? Você se orienta por algum autor?

Como você orienta suas ações? *

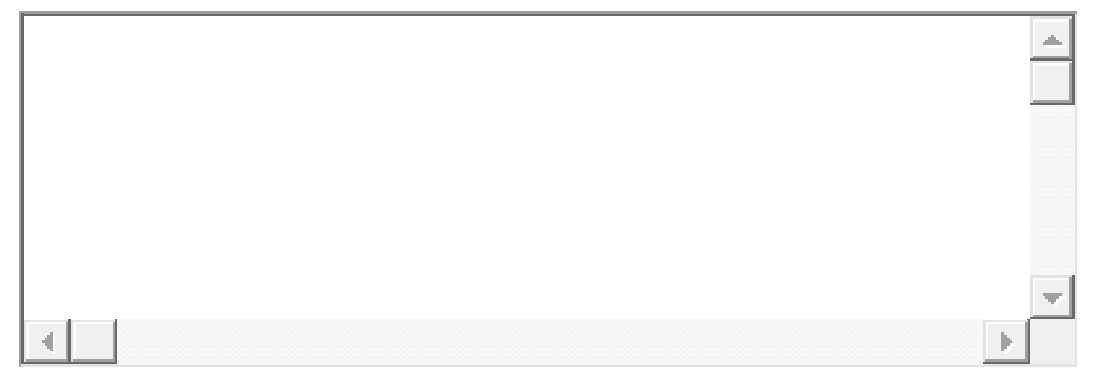

Que habilidades você acredita que uma experiência de aprendizado audiovisual pode despertar? Quais as principais habilidades que você busca despertar nos alunos? *

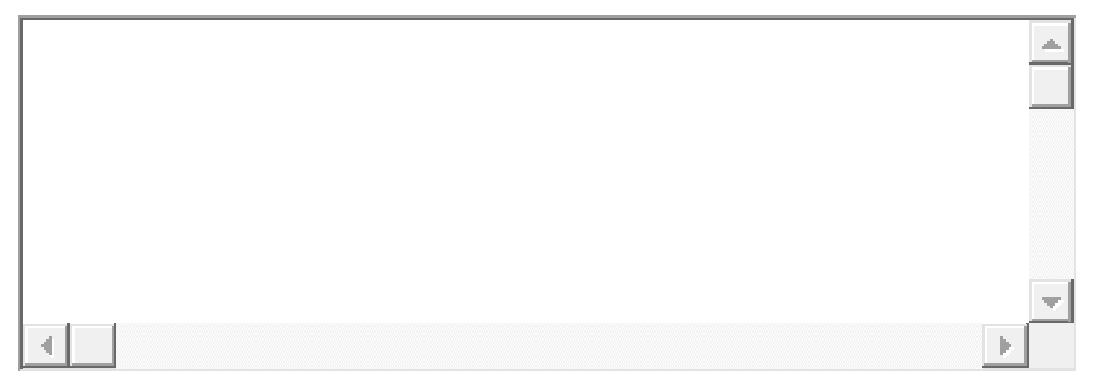

Como você avalia a importância do processo criativo, de elaboração de roteiros, na formação dos alunos? * Conte um pouco sobre suas estratégias para despertar a criatividade de seus alunos. 


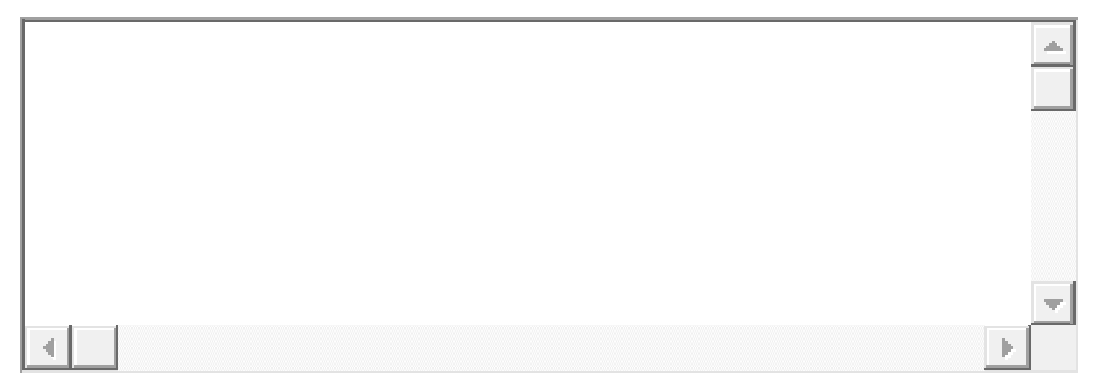

Você acredita que aspectos como a participação dos alunos, a disponibilização de alimentação, o acesso a equipamentos, etc, constituem-se ferramentas importantes de gestão? * Conte um pouco como você lida com esses assuntos.

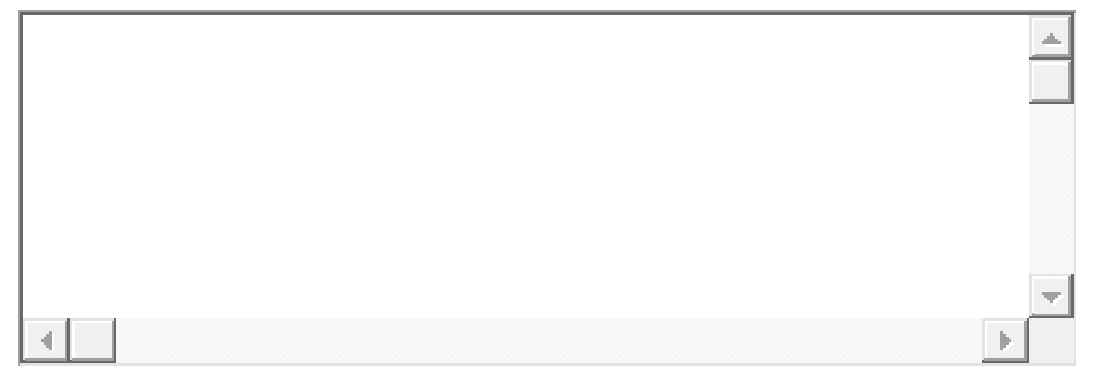

A profissionalização dos alunos é um objetivo? Um efeito colateral? Como você vê

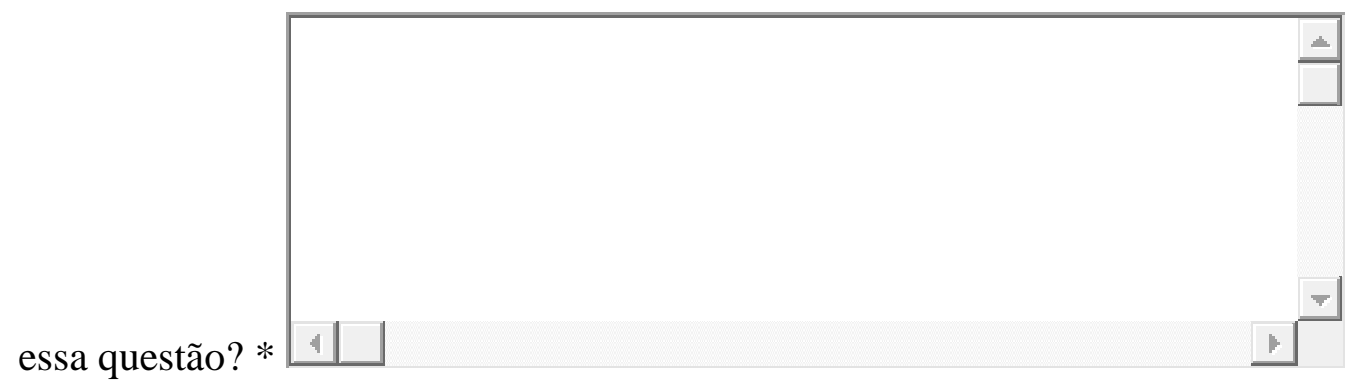

Fale um pouco das relações educador-educando: limites éticos, hierarquia, contato fora da entidade, relações afetivas * Você estabelece limites ou propõe reflexões sobre o assunto com a equipe de educadores? De que tipo? Na sua experiência, houve fatos relevantes que você possa compartilhar?

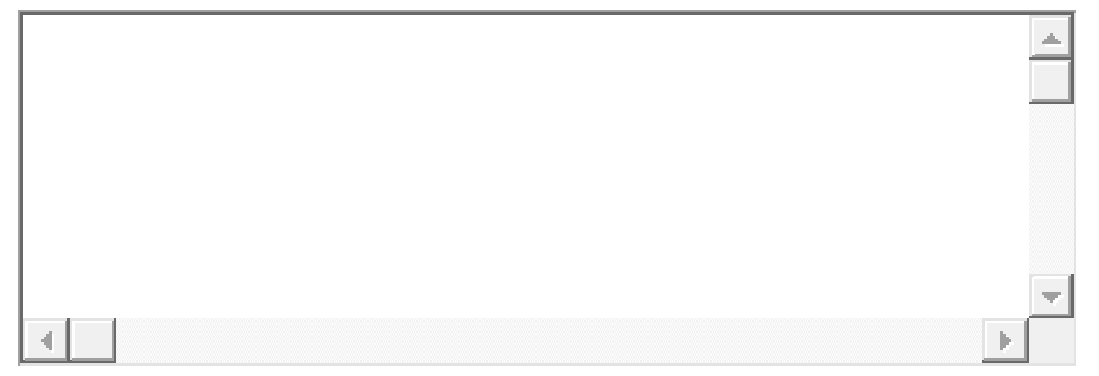


Como você vê a questão da diferença social entre equipe da entidade e educandos? * Você acha que essa diferença exige reflexão? Influencia no cotidiano?

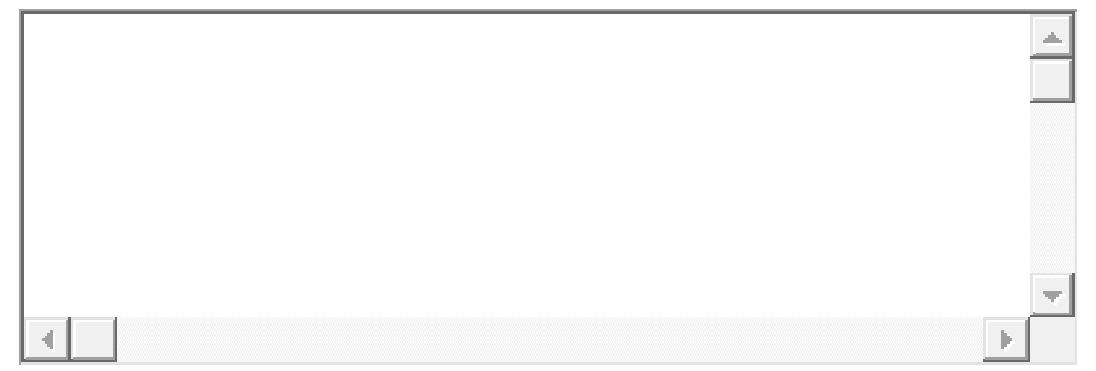

Como se dá o seu trabalho com os educadores? * Selecione, dentre os ítens citados abaixo, aqueles que representam aspectos da sua atuação na relação com os educadores.

- Г Orientação com relação ao calendário.

- Г Orientação com relação ao conteúdo geral do curso.

- Г Orientação ao conteúdo específico do curso que ele irá ministrar.

- $\square$ Orientação sobre a proposta metodológica da entidade ou projeto de ensino audiovisual.

- $\Gamma$ Orientação de leituras e outras referências pedagógicas e culturais.

- $\Gamma$ Atendimento relativo ao comportamento de alunos.

- $\square$ Estabelecimento de limites éticos.

- $\Gamma$ Outro:

Qual você acredita ser seu principal e mais importante papel como coordenador do

projeto? $*$ Justifique.

Como se dá o planejamento pedagógico do projeto de ensino audiovisual? ${ }^{*}$ Escolha a alternativa que mais se assemelha com o processo. 
- O planejamento é realizado coletivamente.

- O planejamento é realizado pela equipe de coordenação e debatido com os educadores.

- O planejamento é realizado apenas pela coordenação e seguido pelos professores.

Qual método é utilizado no planejamento? * Conte um pouco como se dá esse

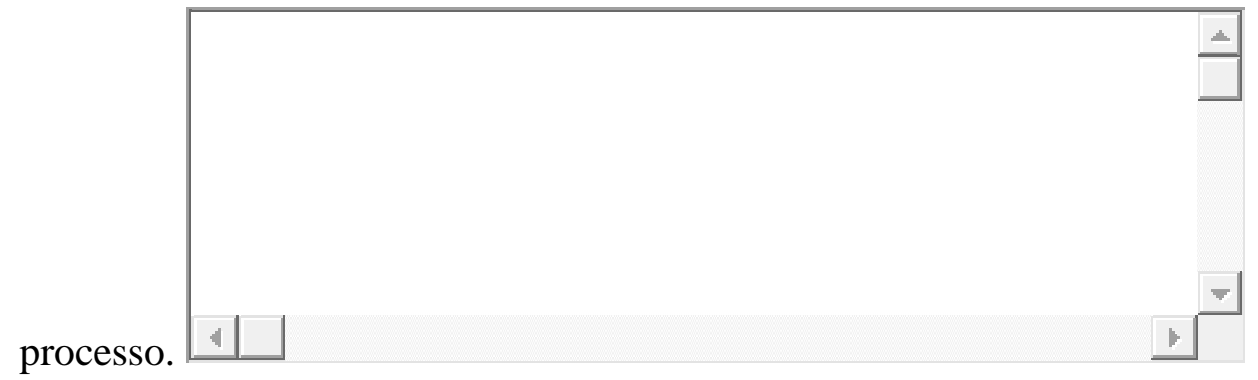

Como se dá o processo seletivo de alunos para o projeto? * Cite que características se busca levar em conta na seleção dos alunos ou que tipo de perfil de alunos se busca

selecionar e como.

A entidade/projeto busca auxiliar alunos e ex-alunos em questões que envolvem suas vidas pessoais? * Por exemplo: se um aluno ou ex-aluno tem um problema familiar (abuso, violência) ou vai preso, a entidade busca auxiliar? Como lida com questões do

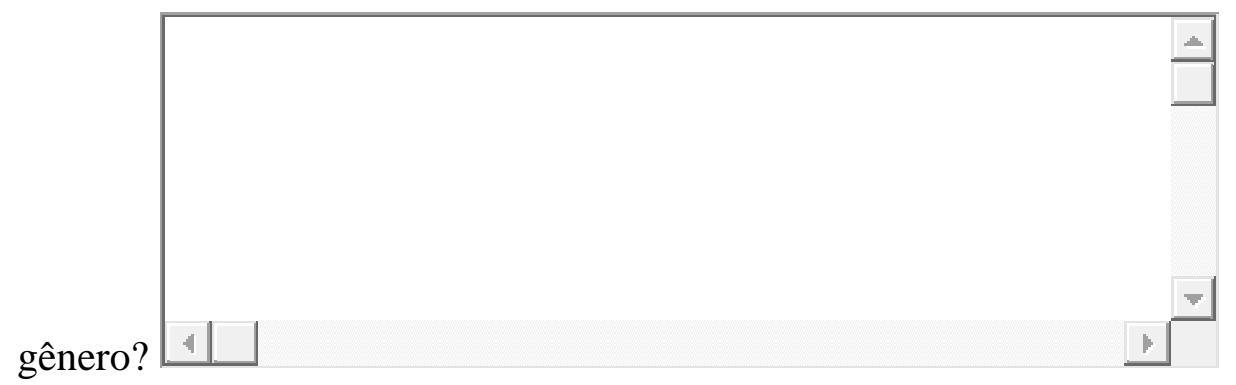

Como a entidade lida com o entorno, comunidades e entidades vizinhas? ${ }^{*}$ Existem atividades de integração? Ou objetivo de realizar algo semelhante? 


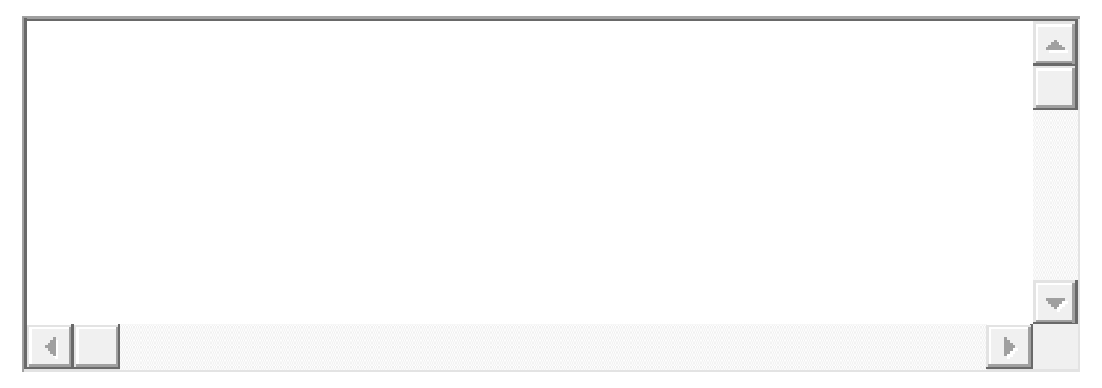

Como você avalia a importância da exibição pública dos produtos audiovisuais resultantes das Oficinas? *

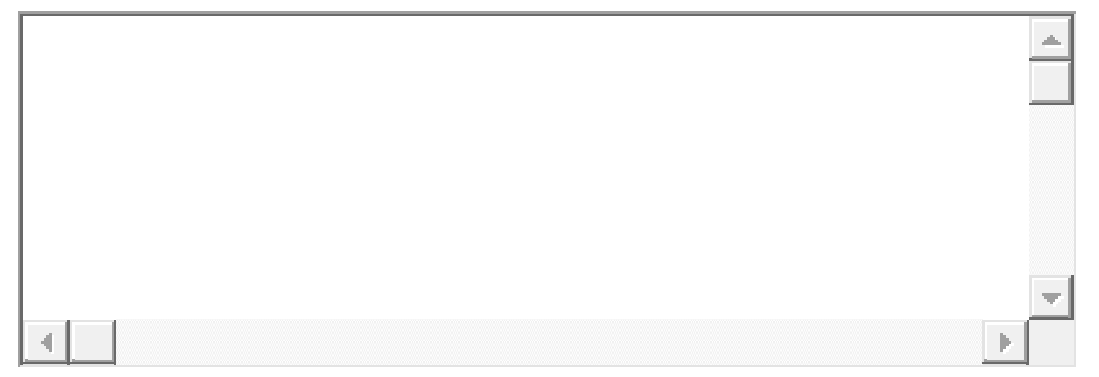

Que tipo de ações a entidade/projeto realiza visando dar suporte aos alunos após as oficinas? * Existem ações voltadas para ex-alunos? Ou atividades que os preparem

para essa nova etapa?

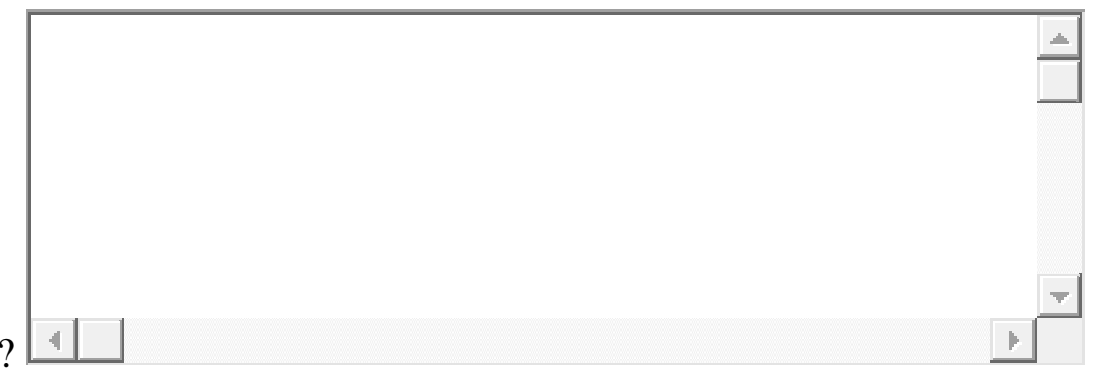

Quais os principais desafios do seu cotidiano? * Selecione os ítens que mais correspondem ao seu dia a dia.

- $\quad$ Falta de recursos

- $\quad$ Falta de tempo para planejamento

- $\square$ Falta de preparo pedagógico

- $\square$ Equipe reduzida

- $\square$ Ausência de recursos para remunerar reuniões

- $\square$ Realizar atendimento individual para os alunos.

- $\square$ Realizar atendimento às famílias dos alunos. 
- $\Gamma$ Dar suporte aos problemas das vidas pessoais dos alunos e equipe.

- $\Gamma$ Falta de equipamentos.

- $\square$ Insegurança.

- $\Gamma$ Excesso de faltas/ Evasão

- $\Gamma$ Relações afetivas entre alunos.

- $\square$ Relações afetivas entre alunos e educadores.

- $\square$ Excesso de visitantes externos / patrocinadores / imprensa

- $\square$ Sobrecarga de funções

- $\square$ Exigências de patrocinadores.

- $\Gamma$ Outro:

Existe algum tipo de ação que vocês realizam, na solução de algum tipo de desafio listado acima, que você acredita que seja exemplar e possa inspirar outros? *

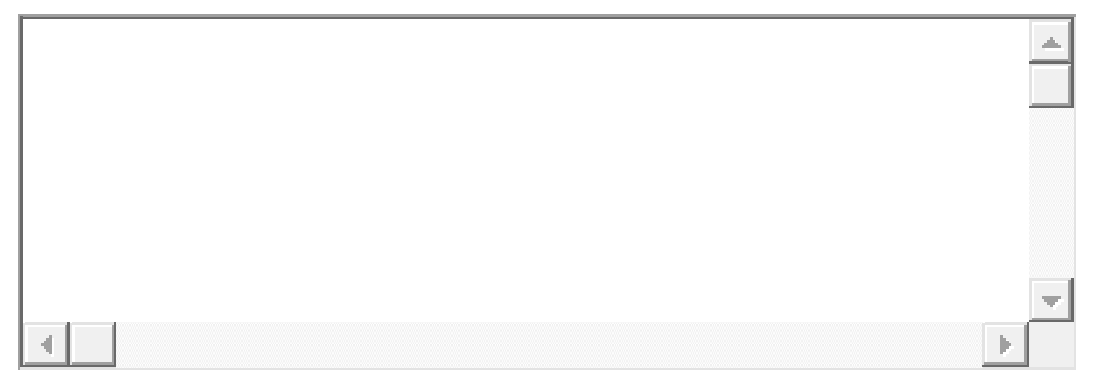

Observações / Informações adicionais * Espaço livre para comentários.
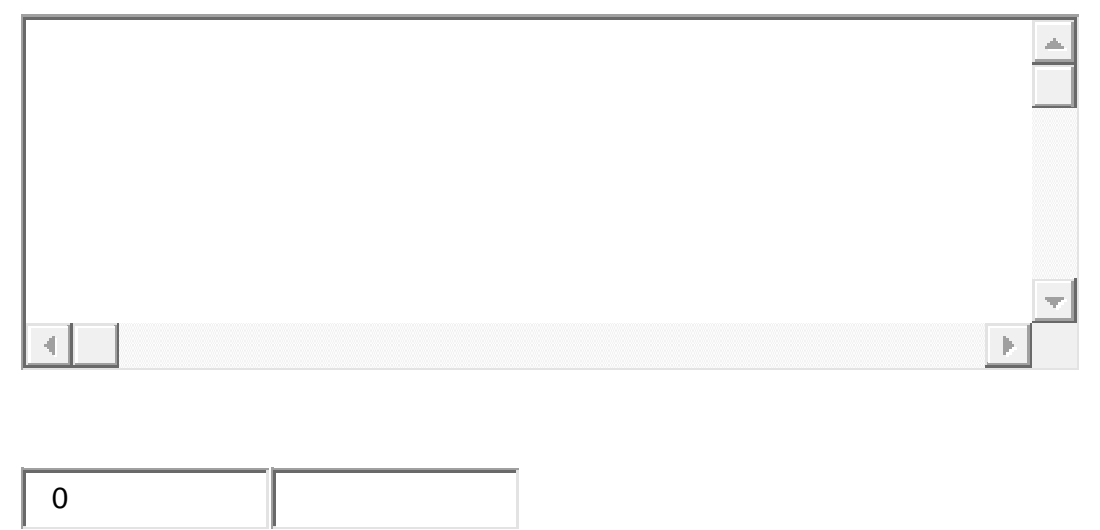

Enviar 


\section{ANEXO J - Questionário educadores}

Disponível em: http://educadoresaudiovisuais.blogspot.com/

*Obrigatório

Nome $*$

E-mail de contato $*$ Pessoal e/ou profissional

Entidade $*$

Projeto de Ensino Audiovisual * (Se for diferente da entidade)

Aulas que ministra. * Se necessário, selecione mais de um.

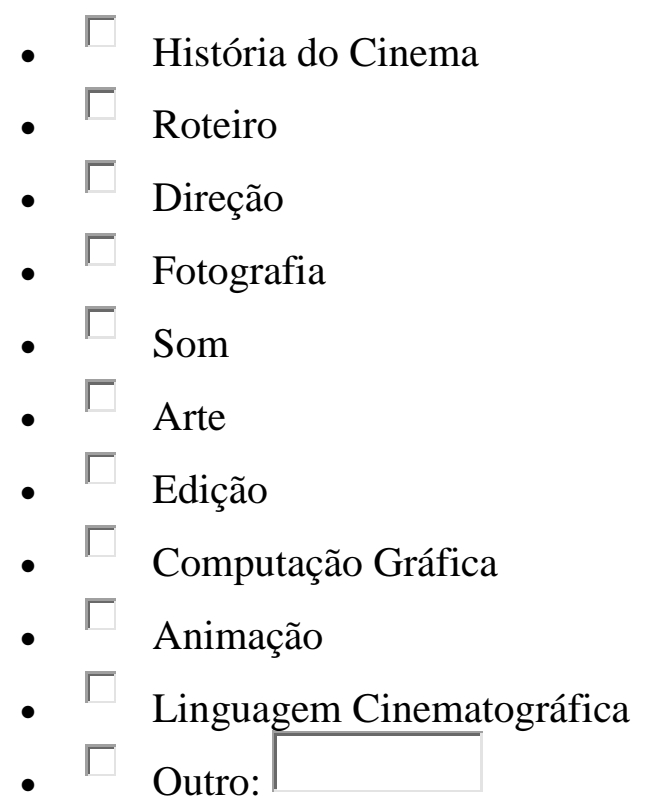

O que o levou a se tornar educador audiovisual? Conte um pouco do seu percurso, 
como chegou à entidade e se preparou para sê-lo. *

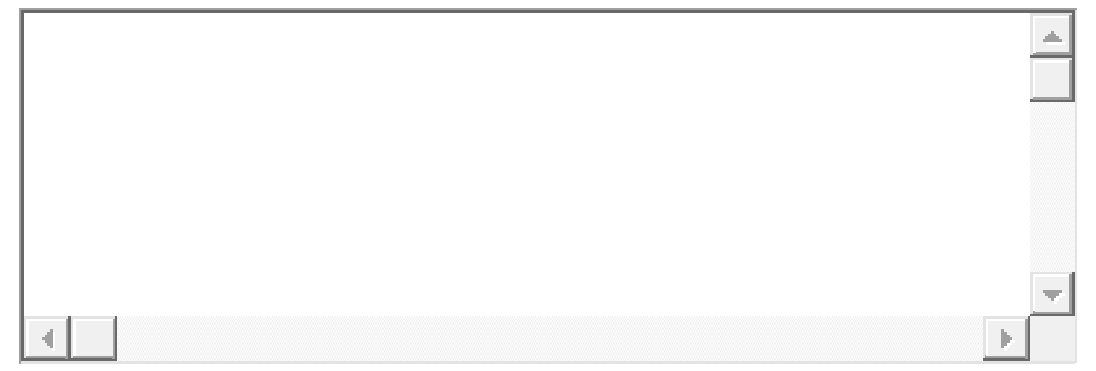

Você tem referências teóricas sobre educação? Você se orienta por algum autor?

Como você orienta suas ações? *

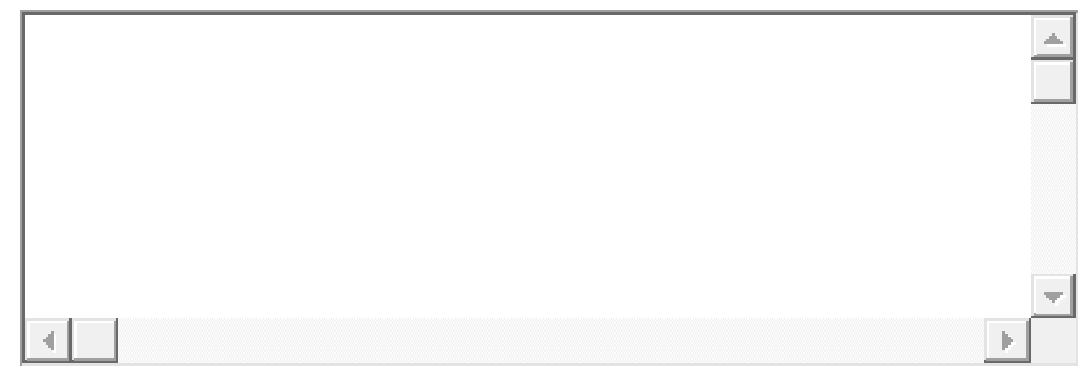

Que habilidades você acredita que uma experiência de aprendizado audiovisual pode despertar? Quais as principais habilidades que você busca despertar nos alunos? *

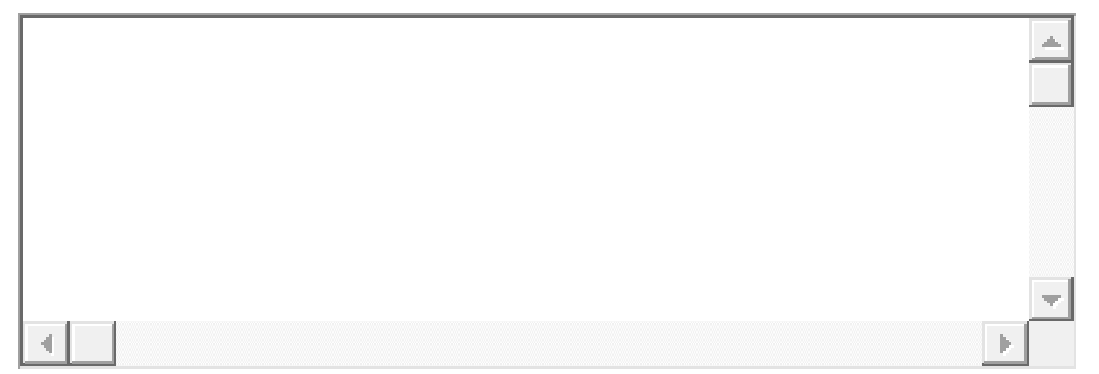

Como você avalia a importância do processo criativo, de elaboração de roteiros, na formação dos alunos? * Conte um pouco sobre suas estratégias para despertar a criatividade de seus alunos.

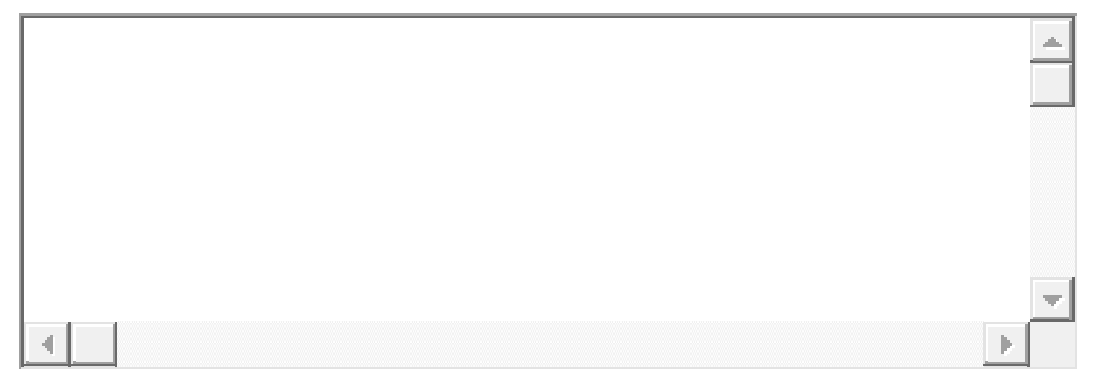


Como você prepara suas aulas? * Detalhe seu percurso, da definição do tema ao

desenho da aula.

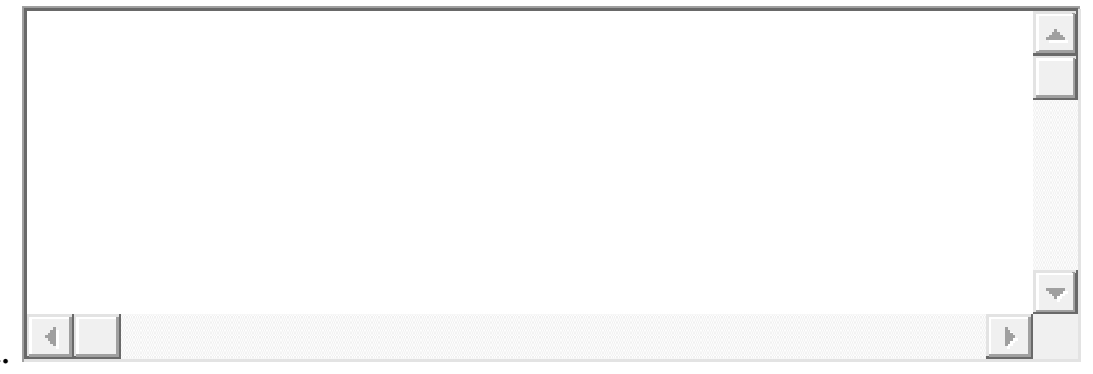

Você criou alguma aula da qual tenha especial orgulho? * Conte em detalhes como a desenvolveu, implantou e quais os resultados.

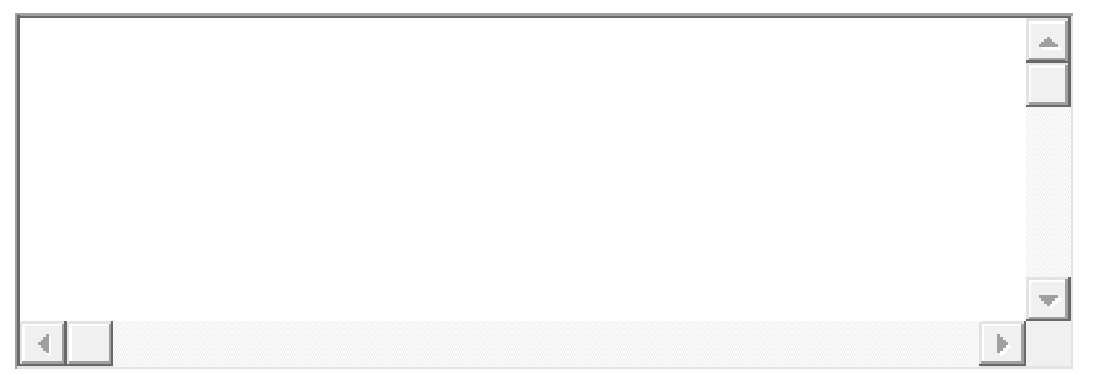

Você acredita que aspectos como a participação dos alunos, a disponibilização de alimentação, o acesso a equipamentos, etc, constituem-se ferramentas importantes de gestão? * Conte um pouco como você lida com esses assuntos.

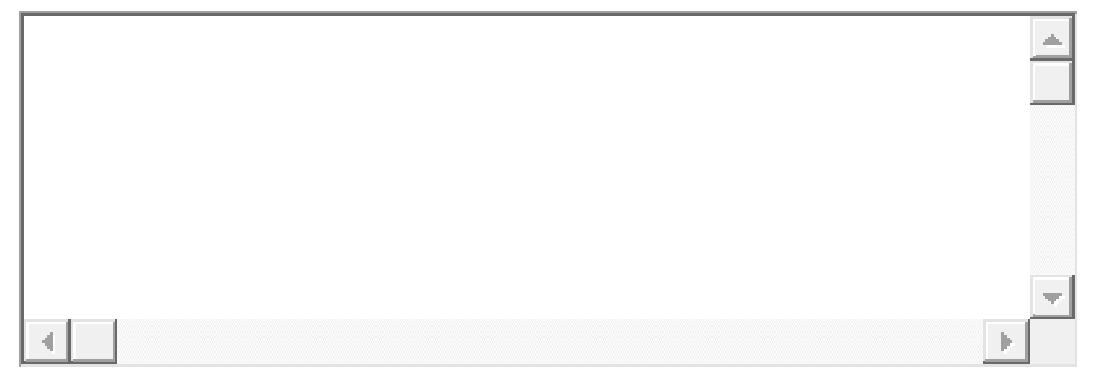

A profissionalização dos alunos é um objetivo? Um efeito colateral? Como você vê

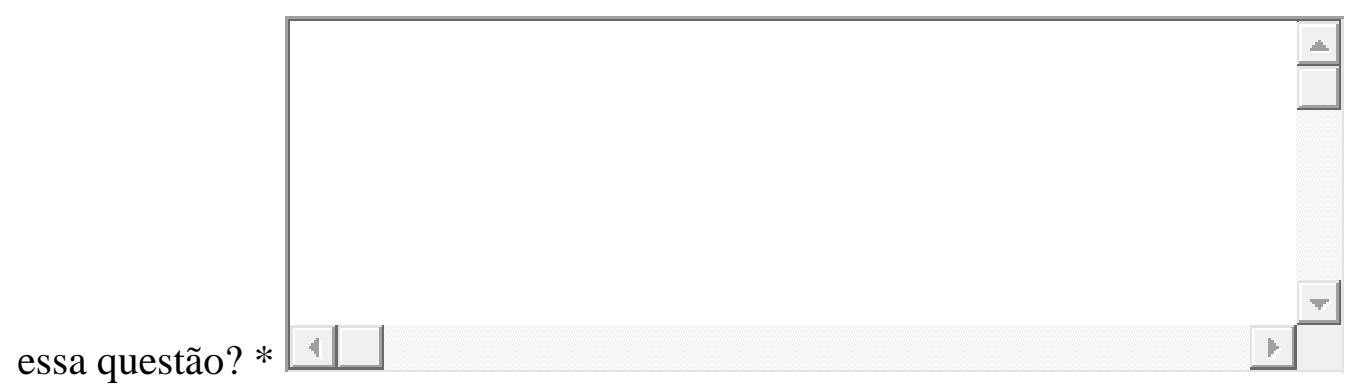

Fale um pouco das relações educador-educando: limites éticos, hierarquia, contato 
fora da entidade, relações afetivas * Você estabelece limites na sua relação com os alunos? Fornece o telefone celular? Encontra-se com eles informalmente para confraternizações? Toma ou tomaria cerveja com alunos maiores de idade? Na sua experiência, houve fatos relevantes que você possa compartilhar? Como você vê esses

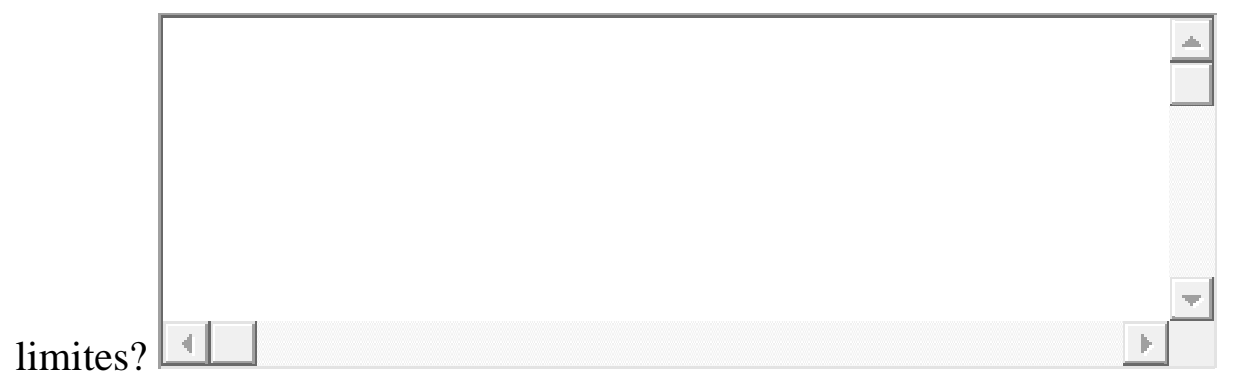

Como você vê a questão da diferença social entre equipe da entidade e educandos? * Você acha que essa diferença exige reflexão? Influencia no cotidiano?

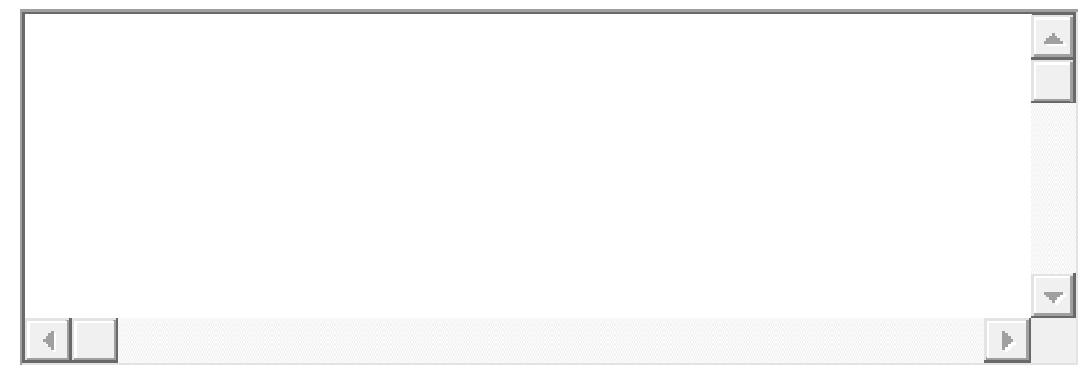

Como se dá o trabalho do coordenador do projeto em que você atua? Em que aspectos você sente que ele auxilia os educadores e demais? * Selecione, dentre os ítens citados abaixo, aqueles que representam aspectos da contribuição do coordenador no processo educativo da entidade.

- $\Gamma$ Orientação com relação ao calendário.

- Г Orientação com relação ao conteúdo geral do curso.

- - Orientação ao conteúdo específico do curso que você irá ministrar.

- $\square$ Orientação sobre a proposta metodológica da entidade ou projeto de ensino audiovisual.

- $\square$ Orientação de leituras e outras referências pedagógicas e culturais.

- $\Gamma$ Atendimento relativo ao comportamento de alunos.

- $\square$ Estabelecimento de limites éticos.

- $\ulcorner$ Outro: 
Qual você acredita ser seu principal e mais importante papel como educador? *

Justifique.

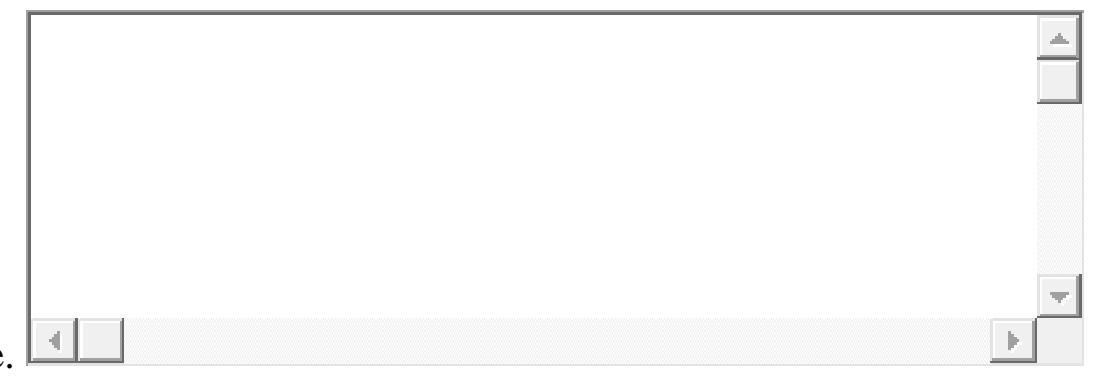

Como se dá o planejamento pedagógico do projeto de ensino audiovisual? * Escolha a alternativa que mais se assemelha com o processo.

- O planejamento é realizado coletivamente.

- O planejamento é realizado pela equipe de coordenação e debatido com os educadores.

- O planejamento é realizado apenas pela coordenação e seguido pelos professores.

Como você se sente nesse processo de planejamento? Você acha que ele contempla suas necessidades como educador? * Conte um pouco como se dá esse processo.

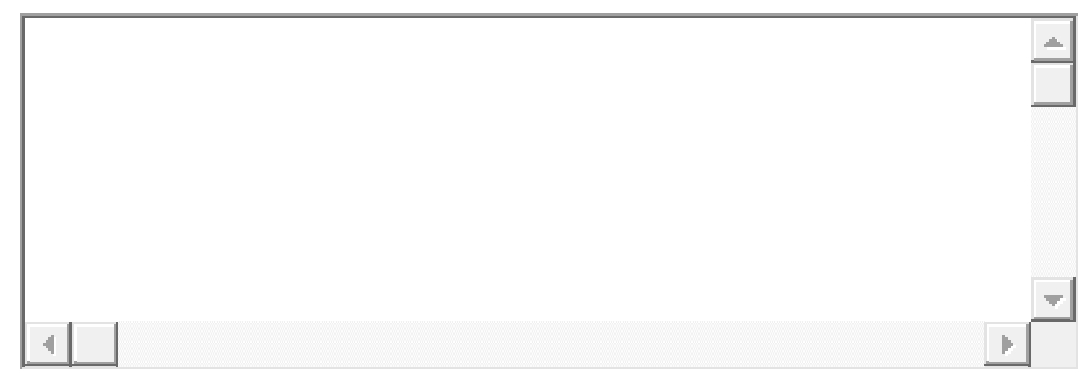

Como você lida com questões relativas às vidas pessoais de seus alunos? * Por exemplo: se um aluno ou ex-aluno tem um problema familiar (abuso, violência) ou vai preso, você busca auxiliar? Como lida com questões do gênero?

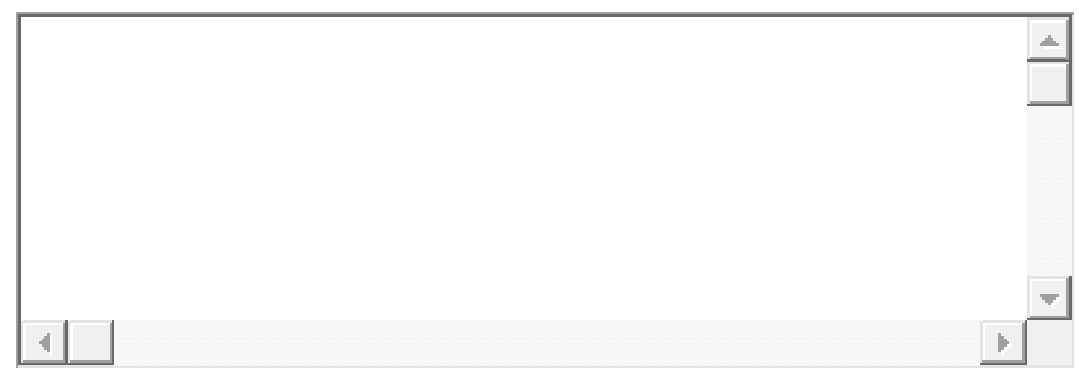


Como você avalia a importância da exibição pública dos produtos audiovisuais resultantes das Oficinas? *

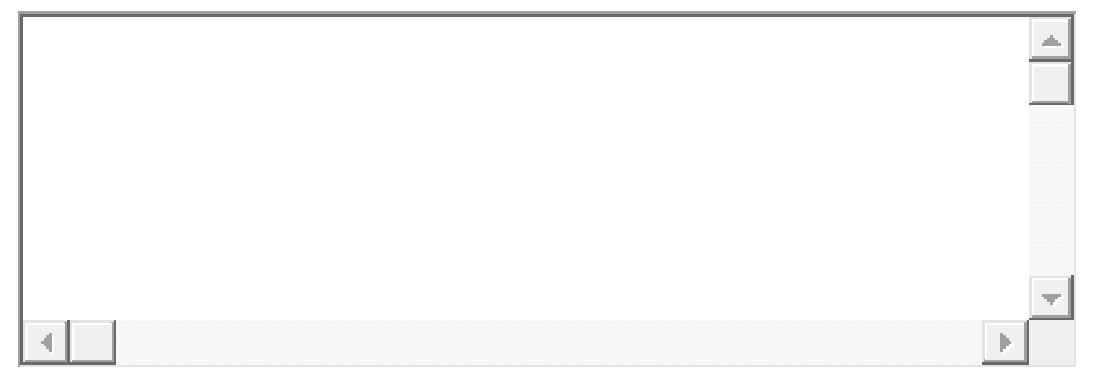

Observações / Informações adicionais * Espaço livre para comentários.

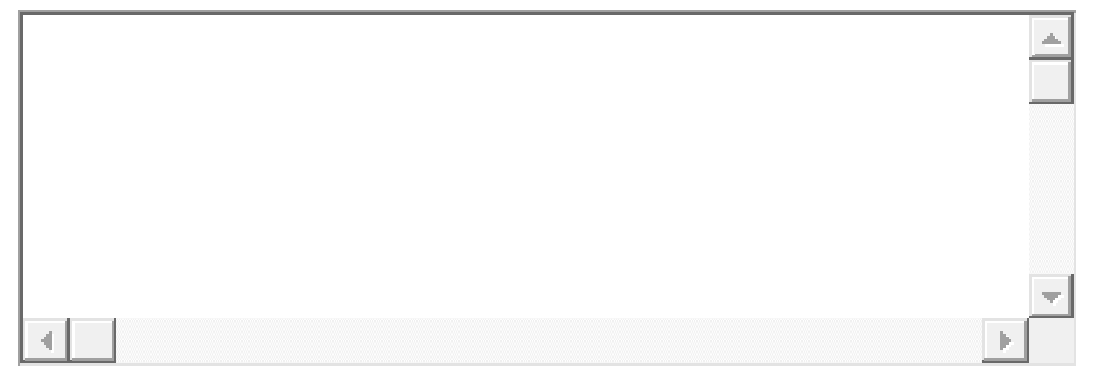

$$
0
$$

Enviar 


\section{ANEXO L - Questionário ex-alunos}

Disponível em: http://alunosexalunos.blogspot.com/

Nome do Aluno

E-mail de Contato

Ano de Nascimento (Ex: 1990)

Terminou o ensino fundamental?

\begin{tabular}{ll|l} 
- & Sim \\
- & Não
\end{tabular}

Terminou o ensino médio?

$\begin{array}{ll}\text { - } & \text { Sim } \\ -\quad & \text { Não }\end{array}$

Está estudando agora? Em que série está?

Com relação ao ensino superior:

- Não está cursando e não pretende cursar.

- Não está cursando mas pretende cursar.

- $C$ Está cursando.

- $C$ É formado no ensino superior. 
Ainda com relação ao ensino superior: Que faculdade está cursando ou pretende cursar?

Religião

Raça Como você se define?

$$
\begin{array}{lcll} 
& \mathrm{C} & \text { Negro } \\
- & \mathrm{O} & \text { Branco } \\
- & \mathrm{O} & \text { Mulato/Pardo } \\
- & \mathrm{O} & \text { Indígena } \\
- & & \text { Oriental } \\
- & \mathrm{O} & \\
- & \mathrm{O} & \text { Outro: }
\end{array}
$$

Mora com os pais? $\square$
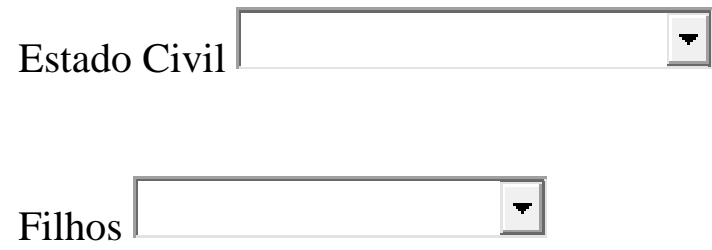

Quantas pessoas moram na sua casa?

Renda Familiar (Renda somada de todos os membros que moram em sua casa)

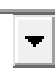

Nome do Projeto/Oficina Audiovisual que cursou $*$

Em que ano realizou o curso/oficina de formação audiovisual? * 
Cidade *

Estado $*$

Porque você procurou a Oficina/Projeto Audiovisual? * Selecione a resposta mais parecida com os motivos que o levaram ao Projeto.
- $C$ Para ocupar o tempo livre.
- $C$ Para aprender uma profissão.
- Para descobrir uma nova forma de me expressar.
- $C$ Para ficar menos tempo na minha casa.
- Para descobrir coisas novas.
- Para conhecer garotas/garotos, fazer amigos, namorar.
- $\quad$ Porque eu sempre quis aprender cinema e surgiu a oportunidade
- Porque eu já fazia outro curso e me interessei, mesmo sem saber o que era.
- $O$ Outro:

Dentre as opções abaixo, qual você considera que era seu principal desafio pessoal quando procurou a Oficina/Projeto Audiovisual? *
- Concentração - Eu não conseguia me focar nas coisas e aprender.
- $\quad$ Respeito - Eu não me relacionava muito bem com as pessoas.
- $\quad$ Interesse - Eu não tinha interesse em muitos assuntos.
- $C$ Aprendizagem - Eu tinha dificuldade em aprender as coisas.
- $\quad$ Auto-Conhecimento - Eu não me conhecia muito bem.
- O Outro:

O que você esperava da Oficina/Curso? * 


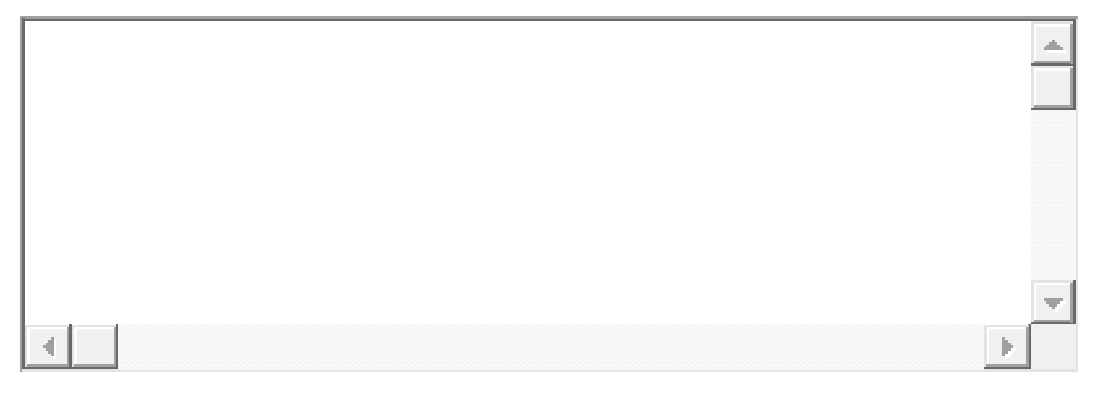

Conte um pouco sobre como você era antes da Oficina: * Fale sobre sua atitude, se era tímido ou extrovertido, se tinha dificuldades de relacionamento, etc.

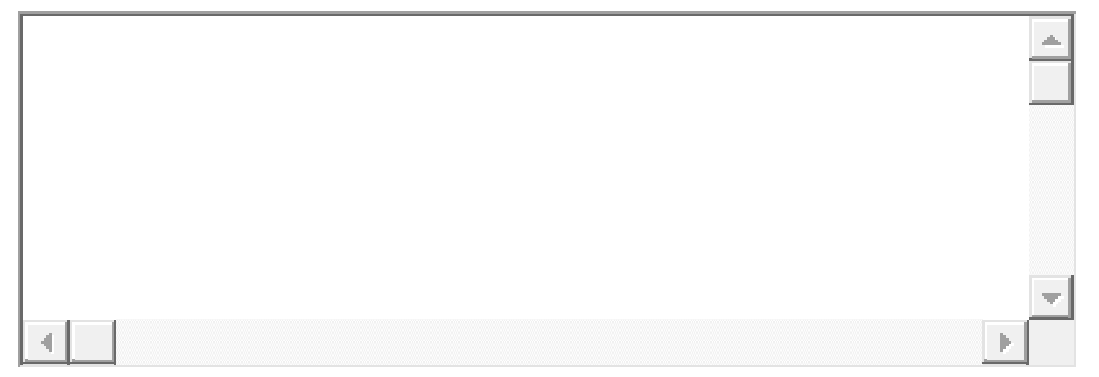

Você tinha preconceitos quando entrou no curso? * Selecione os preconceitos que você tinha. Não tenha vergonha. Todos possuem algum tipo de preconceito.

- $\square$ Preconceito com relação ao Curso / ao Audiovisual.

- $\square$ Preconceito com relação a outras Raças.

- $\square$ Preconceito com relação a outras Religiões.

- Г Preconceito com relação a outras opções sexuais.

- $\Gamma$ Preconceito com relação a outras classes sociais.

- $\square$ Preconceito com relação a imigrantes e migrantes.

- $\square$ Preconceito com relação a mulheres.

- $\ulcorner$ Outro:

A convivência na Oficina/Projeto me ajudou a entender e superar meus preconceitos.

$$
\begin{array}{lllll}
1 & 2 & 3 & 4 & 5
\end{array}
$$

\begin{tabular}{ll|l|l|l|l|l} 
Discordo Muito. & $\odot$ & $C$ & 6 & 6 & 6 & Concordo Muito.
\end{tabular}

Se quiser, fale mais sobre o assunto. * 


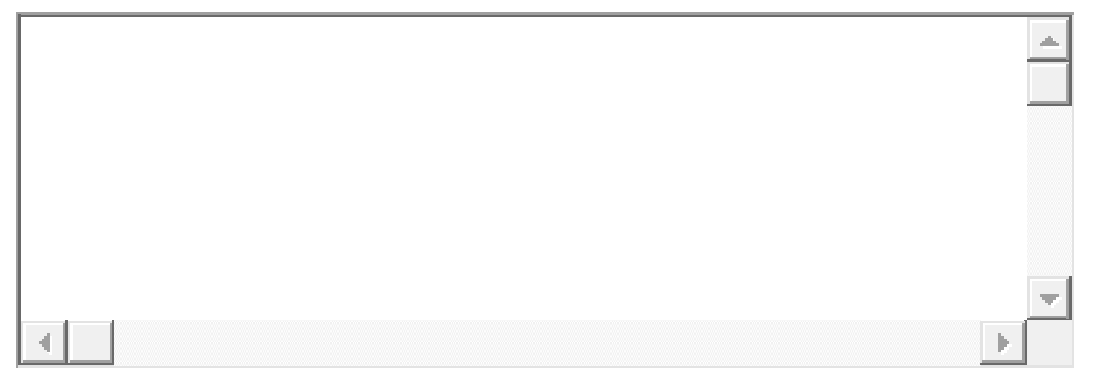

Eu me sentia compreendido pelos meus educadores.

$$
\begin{array}{lllll}
1 & 2 & 3 & 4 & 5
\end{array}
$$

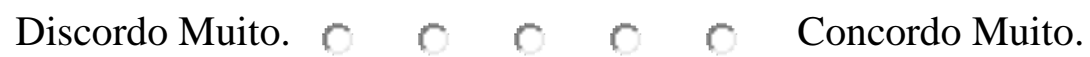

Eu me sentia à vontade para me abrir com meus educadores.

$$
\begin{array}{lllll}
1 & 2 & 3 & 4 & 5
\end{array}
$$

\begin{tabular}{ll|l|l|l|l|l} 
Discordo Muito. & 0 & 0 & 0 & 0 & 0 & Concordo Muito.
\end{tabular}

Meus educadores demonstravam confiança nas minhas capacidades.

$$
\begin{array}{lllll}
1 & 2 & 3 & 4 & 5
\end{array}
$$

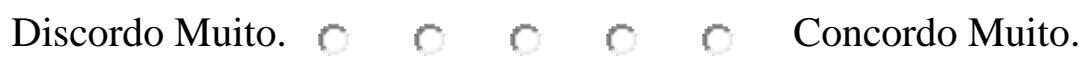

Eu sentia que meus educadores me aceitavam.

$$
\begin{array}{lllll}
1 & 2 & 3 & 4 & 5
\end{array}
$$

\begin{tabular}{ll|l|l|l|l|l} 
Discordo Muito. & 0 & 0 & 0 & 0 & 0 & Concordo Muito.
\end{tabular}

Meus educadores me incentivavam a fazer pesquisas.

$$
\begin{array}{lllll}
1 & 2 & 3 & 4 & 5
\end{array}
$$

\begin{tabular}{ll|l|l|l|l|l} 
Discordo Muito. & 0 & $\odot$ & $\odot$ & 0 & 0 & Concordo Muito.
\end{tabular}

Meus educadores me incentivavam a fazer perguntas.

$$
\begin{array}{lllll}
1 & 2 & 3 & 4 & 5
\end{array}
$$


\begin{tabular}{ll|l|l|l|l|l} 
Discordo Muito. & $\odot$ & $\odot$ & $\odot$ & 0 & & Concordo Muito.
\end{tabular}

Eu confiava muito em meus educadores.

$$
\begin{array}{lllll}
1 & 2 & 3 & 4 & 5
\end{array}
$$

\begin{tabular}{ll|l|l|l|l|l} 
Discordo Muito. & $\odot$ & $\odot$ & 6 & 6 & 0 & Concordo Muito.
\end{tabular}

Meus educadores respondiam minhas questões com interesse e atenção.

$$
\begin{array}{lllll}
1 & 2 & 3 & 4 & 5
\end{array}
$$

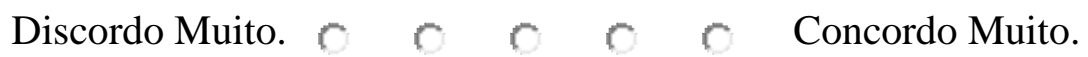

Meus educadores costumavam escutar de que maneira eu gostaria de fazer as coisas.

$$
\begin{array}{lllll}
1 & 2 & 3 & 4 & 5
\end{array}
$$

\begin{tabular}{ll|l|l|l|l|l} 
Discordo Muito. & 0 & 0 & $C$ & 0 & 0 & Concordo Muito.
\end{tabular}

Meus educadores lidavam bem com os problemas emocionais da turma, de uma forma geral.

$$
\begin{array}{lllll}
1 & 2 & 3 & 4 & 5
\end{array}
$$

\begin{tabular}{ll|l|l|l|l|l} 
Discordo Muito. & $\odot$ & $\odot$ & $\odot$ & $\ddots$ & $\ddots$ & Concordo Muito.
\end{tabular}

Eu sentia que meus educadores se importavam comigo como pessoa.

$\begin{array}{lllll}1 & 2 & 3 & 4 & 5\end{array}$

Discordo Muito. \begin{tabular}{c|c|c|c|c|c} 
& 0 & 0 & 0 & 0 & Concordo Muito.
\end{tabular}

Indique aqui quais você acredita que foram seus principais aprendizados a partir da Oficina/Projeto Audiovisual. * Cite quantos quiser e fale à vontade sobre o assunto. 


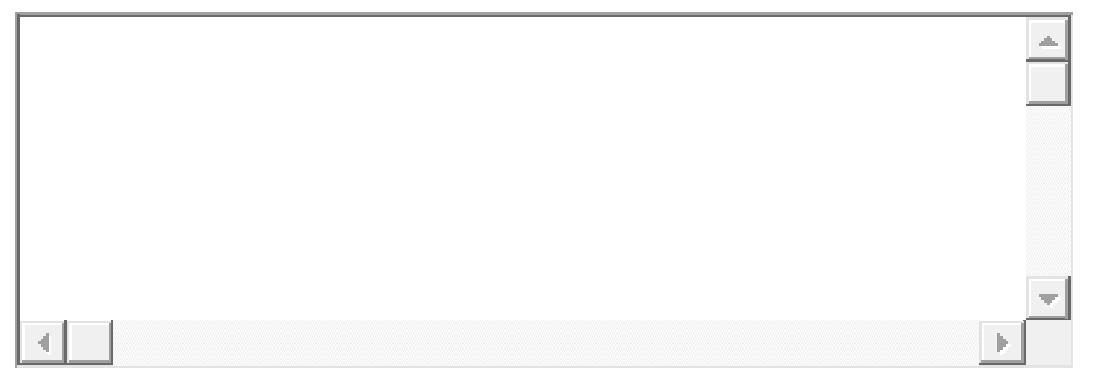

Eu me sentia muito bem com a forma que meus educadores falavam comigo.

$$
\begin{array}{lllll}
1 & 2 & 3 & 4 & 5
\end{array}
$$

Discordo Muito. \begin{tabular}{l|l|l|l|l|l} 
& 0 & 0 & 0 & 0 & Concordo Muito.
\end{tabular}

Eu me sentia com liberdade para dividir meus sentimentos e problemas pessoais com meus educadores.

$$
\begin{array}{lllll}
1 & 2 & 3 & 4 & 5
\end{array}
$$

Discordo Muito. \begin{tabular}{c|c|c|c|c|c}
$\mathrm{C}$ & $\mathrm{C}$ & $\mathrm{C}$ & $\mathrm{C}$ & $\mathrm{C}$ & Concordo Muito.
\end{tabular}

No projeto, eu aprendi a gostar de assistir filmes brasileiros

$$
\begin{array}{lllll}
1 & 2 & 3 & 4 & 5
\end{array}
$$

Discordo Muito. \begin{tabular}{c|c|c|c|c|c}
$\mathrm{C}$ & $\mathrm{C}$ & $\mathrm{C}$ & $\mathrm{C}$ & Concordo Muito.
\end{tabular}

No projeto, eu aprendi a ver televisão com outros olhos

$$
\begin{array}{lllll}
1 & 2 & 3 & 4 & 5
\end{array}
$$

\begin{tabular}{ll|l|l|l|l|l} 
Discordo Muito. & $\mathrm{O}$ & $\mathrm{O}$ & $\mathrm{C}$ & $\mathrm{O}$ & $\mathrm{C}$ & Concordo Muito.
\end{tabular}

No projeto, eu aprendi a ser um profissional da área audiovisual

$$
\begin{array}{lllll}
1 & 2 & 3 & 4 & 5
\end{array}
$$

\begin{tabular}{ll|l|l|l|l|l} 
Discordo Muito. & & 0 & 6 & 0 & 0 & Concordo Muito.
\end{tabular}

No projeto, eu descobri muitas coisas sobre mim mesmo

$$
\begin{array}{lllll}
1 & 2 & 3 & 4 & 5
\end{array}
$$


\begin{tabular}{ll|l|l|l|l|l} 
Discordo Muito. & $\odot$ & $\odot$ & $\odot$ & 0 & & Concordo Muito.
\end{tabular}

No projeto, eu aprendi a pesquisar sozinho, na Biblioteca e na internet

$$
\begin{array}{lllll}
1 & 2 & 3 & 4 & 5
\end{array}
$$

\begin{tabular}{ll|l|l|l|l|l} 
Discordo Muito. & $\odot$ & $\odot$ & 6 & 6 & 0 & Concordo Muito.
\end{tabular}

No projeto, eu descobri que gosto muito de criar e me expressar através do audiovisual

$$
\begin{array}{lllll}
1 & 2 & 3 & 4 & 5
\end{array}
$$

\begin{tabular}{ll|l|l|l|l|l} 
Discordo Muito. & 0 & $\odot$ & 6 & 0 & 0 & Concordo Muito.
\end{tabular}

No projeto, eu aprendi a trabalhar em grupo

$$
\begin{array}{lllll}
1 & 2 & 3 & 4 & 5
\end{array}
$$

Discordo Muito. \begin{tabular}{c|c|c|c|c|c} 
& 0 & 0 & 0 & 0 & Concordo Muito.
\end{tabular}

No projeto, eu aprendi a fazer criticas de maneira respeitosa.

$$
\begin{array}{lllll}
1 & 2 & 3 & 4 & 5
\end{array}
$$

\begin{tabular}{ll|l|l|l|l|l} 
Discordo Muito. & $\odot$ & $\odot$ & $\odot$ & $C$ & $\ddots$ & Concordo Muito.
\end{tabular}

No projeto, eu aprendi a ouvir críticas.

$$
\begin{array}{lllll}
1 & 2 & 3 & 4 & 5
\end{array}
$$

\begin{tabular}{ll|l|l|l|l|l} 
Discordo Muito. & $\odot$ & $\odot$ & & & $\wp$ & Concordo Muito.
\end{tabular}

No projeto, eu entendi que tenho direito de participar das decisões

$$
\begin{array}{lllll}
1 & 2 & 3 & 4 & 5
\end{array}
$$

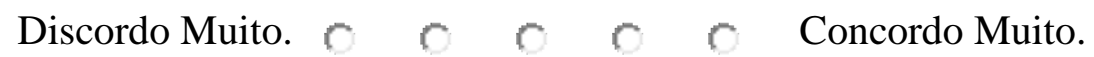

No projeto, eu descobri uma alternativa profissional que não conhecia. 


$\begin{array}{lllll}1 & 2 & 3 & 4 & 5\end{array}$

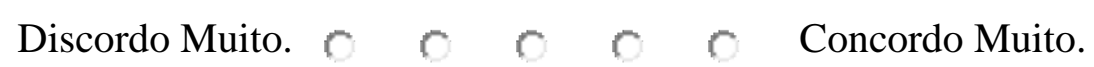

No projeto, eu aprendi a profissão da qual eu hoje sobrevivo.

$\begin{array}{lllll}1 & 2 & 3 & 4 & 5\end{array}$

\begin{tabular}{ll|l|l|l|l|l} 
Discordo Muito. & & 0 & 0 & 0 & 0 & Concordo Muito.
\end{tabular}

No projeto, eu aprendi a me preocupar mais com os problemas do mundo.

$\begin{array}{lllll}1 & 2 & 3 & 4 & 5\end{array}$

\begin{tabular}{ll|l|l|l|l|l} 
Discordo Muito. & & 0 & 0 & 0 & 0 & Concordo Muito.
\end{tabular}

Você tem interesse em se tornar educador audiovisual?
- Sim, no futuro.
- Sim, já estou me preparando para isso.
- $\quad$ Não, não tenho interesse.

Você já se apaixonou por um educador da oficina audiovisual? Você acha que isso é comum? Como acha que as pessoas deveriam lidar com isso?

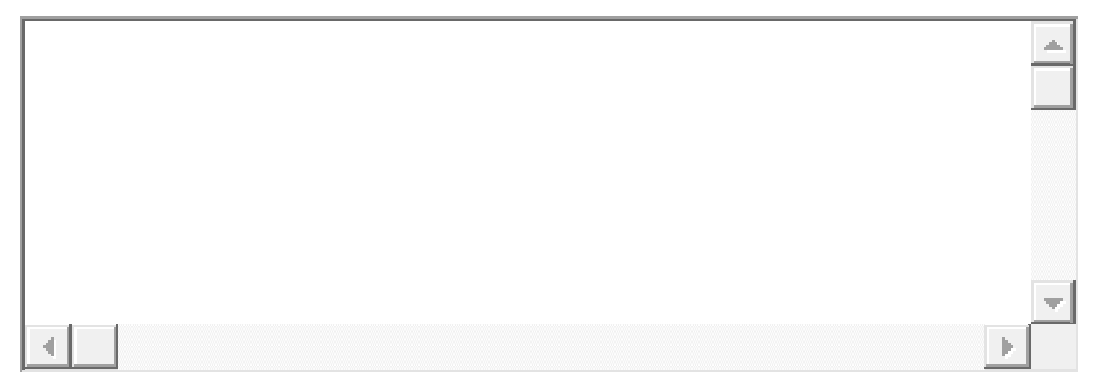

Quais são seus projetos envolvendo o audiovisual hoje? 


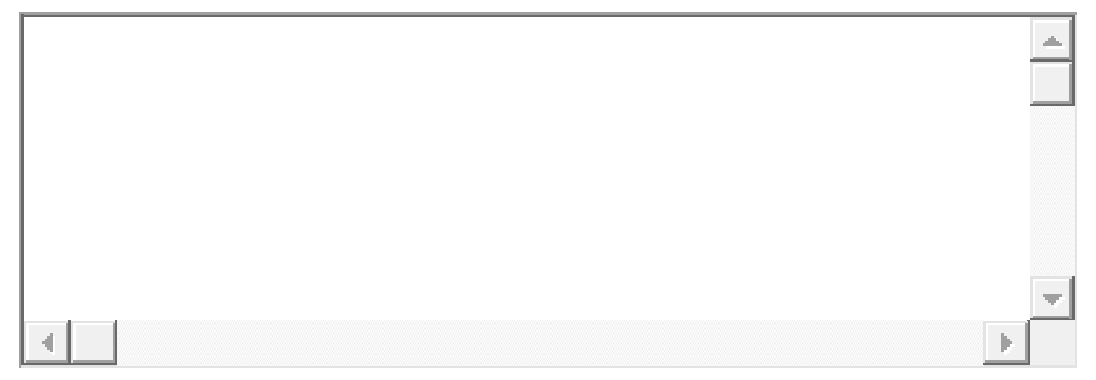

Como seu envolvimento com o audiovisual interferiu no seu projeto de vida? Algo

mudou?

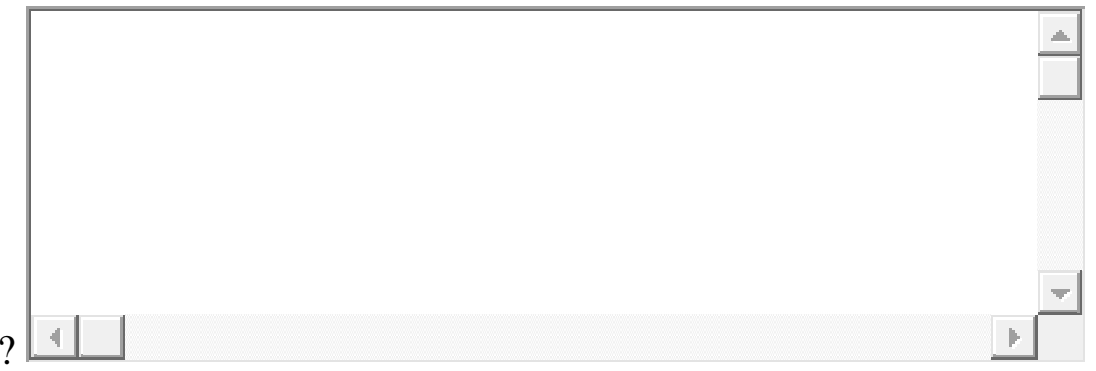

Se você pudesse reinventar a educação, como ela seria? O que teria de novo? E com o

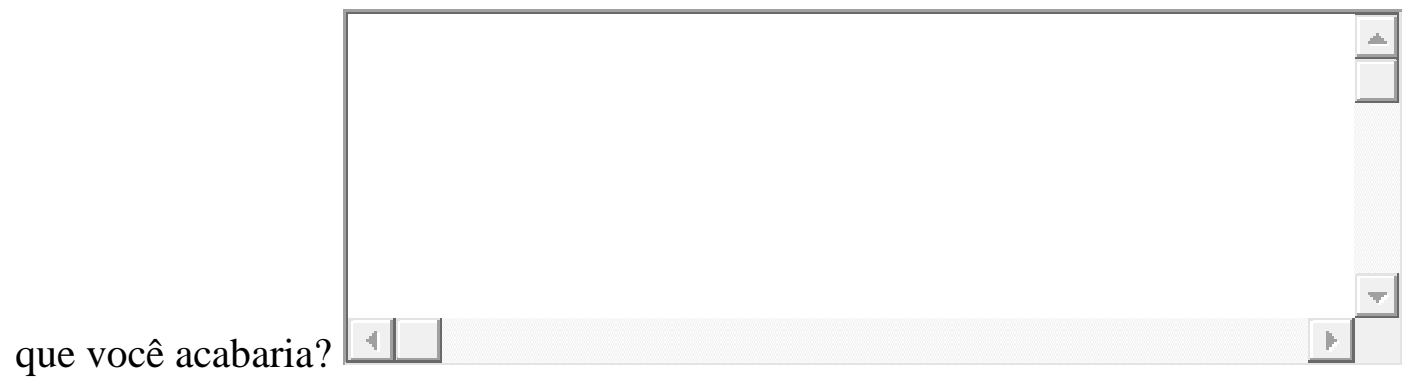

QUESTIONÁRIO TESTE: Quanto tempo vc demorou para preencher o questionário?

Se quiser aproveite e comente aqui o que achou, se sentiu-se bem preenchendo, se achou alguma coisa estranha ou se quer sugerir algo....

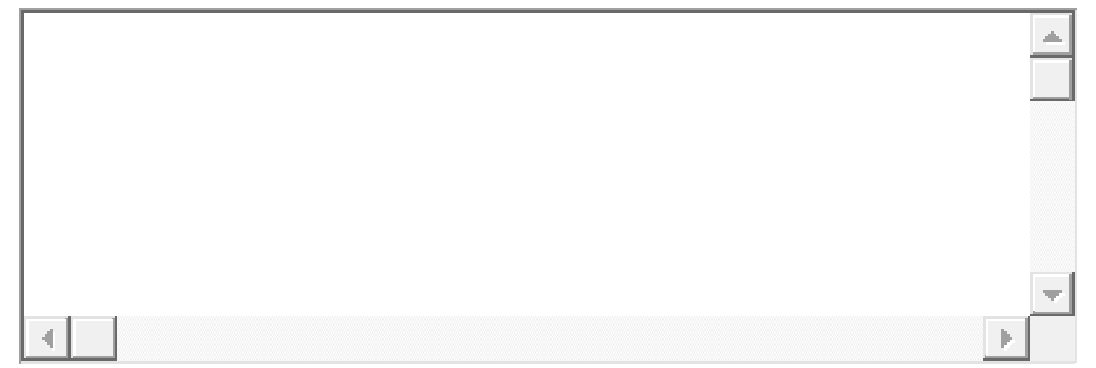

0

Enviar 


\section{ANEXO M - Edital VAI}

Lei VAI

LEI N ${ }^{\circ}$ 13.540, DE 24 DE MARÇO DE 2003 (Projeto de Lei nº 681/02, doVereador Nabil Bonduki - PT).

Institui o Programa para a Valorização de Iniciativas Culturais - VAI - no âmbito da Secretaria Municipal de Cultura e dá outras providências.

MARTA SUPLICY, Prefeita do Município de São Paulo, no uso das atribuições que lhe são conferidas por lei, faz saber que a Câmara Municipal, em sessão de 19 de fevereiro de 2003, decretou e eu promulgo a seguinte lei

Art. $1^{\circ}$ - Fica instituído o Programa para a Valorização de Iniciativas Culturais - VAI - no âmbito da Secretaria Municipal de Cultura, com a finalidade de apoiar financeiramente, por meio de subsídio, atividades artístico-culturais, principalmente de jovens de baixa renda e de regiões do Município desprovidas de recursos e equipamentos culturais.

Art. $2^{\circ}$ - O Programa VAI tem por objetivos:

I - estimular a criação, o acesso, a formação e a participação do pequeno produtor e criador no desenvolvimento cultural da cidade;

II - promover a inclusão cultural;

III - estimular dinâmicas culturais locais e a criação artística.

Art. $3^{\circ}$ - Poderão ser destinados ao Programa VAI recursos provenientes de convênios, contratos e acordos no âmbito cultural celebrados entre instituições públicas ou privadas, nacionais ou estrangeiras e a Secretaria Municipal de Cultura. 
Art. $4^{\circ}$ - Os recursos destinados ao Programa VAI deverão ser aplicados em atividades que visem fomentar e estimular a produção cultural no Município de São Paulo vinculada a diversas linguagens artísticas, consagradas ou não, relativas a artes e humanidades ou a temas relevantes para o desenvolvimento cultural e formação para a cidadania cultural no Município.

Parágrafo único - É vedada a aplicação de recursos do Programa VAI em projetos de construção ou conservação de bens imóveis ou em projetos originários dos poderes públicos municipal, estadual ou federal.

Art. $5^{\circ}$ - Fica criada a Comissão de Avaliação de Propostas do Programa VAI, com a finalidade de selecionar as propostas e avaliar o resultado daquelas aprovadas.

$\S 1^{\circ}$ - A comissão será composta por 08 (oito) membros, sendo 04 (quatro) representantes do Executivo e 04 (quatro) representantes de entidades do setor cultural da sociedade civil.

$\S 2^{\circ}$ - Os representantes do Executivo deverão ser designados pelo Secretário Municipal de Cultura e os representantes da sociedade civil, pelo Conselho Municipal de Cultura, dentre as entidades nele cadastradas.

$\S 3^{\circ}$ - Os membros da Comissão de Avaliação terão mandato de 01 (um) ano, podendo ser reconduzidos uma vez por igual período.

$\S 4^{\circ}$ - A Comissão de Avaliação será presidida por um dos representantes do Executivo, designado pelo Secretário Municipal de Cultura.

$\S 5^{\circ}$ - O presidente da Comissão de Avaliação terá direito a um segundo voto em casos de empate.

$\S 6^{\circ}$ - Enquanto o Conselho Municipal de Cultura não estiver em funcionamento, os representantes da sociedade civil poderão ser indicados pela Secretaria Municipal de Cultura dentre as entidades cadastradas no Conselho.

Art. $6^{\circ}$ - Poderá concorrer a recursos do Programa VAI toda pessoa física ou jurídica sem fins lucrativos, com domicílio ou sede comprovados no Município de São Paulo há no mínimo 02 (dois) anos, que apresentar propostas artístico-culturais de acordo com os requisitos previstos nesta lei. 
Parágrafo único - Não poderão concorrer aos recursos do Programa VAI funcionários públicos municipais, membros da Comissão de Avaliação, seus parentes em primeiro grau e cônjuges.

Art. $7^{\circ}$ - A inscrição para o Programa VAI deverá ser feita de forma simplificada, em locais de fácil acesso e em todas as regiões do Município.

Art. $8^{\circ}$ - O valor destinado a cada proposta será de até R\$ 15.000,00 (quinze mil reais), corrigidos pelo IPCA ou índice que o vier a substituir, podendo haver nova solicitação, consecutiva ou não, por apenas uma vez, de acordo com avaliação realizada pela Comissão de Avaliação.

Parágrafo único - O valor será repassado em até 03 (três) parcelas, a critério da Comissão de Avaliação e de acordo com o cronograma de atividades.

Art. $9^{\circ}$ - Quando a proposta aprovada não resultar em evento gratuito, deverá destinar no mínimo $10 \%$ (dez por cento) de seus produtos ou ações como devolução pública, sob forma de ingressos, doação para escolas e bibliotecas, entre outros.

Art. 10 - A Comissão de Avaliação selecionará os beneficiários analisando o mérito das propostas segundo critérios de clareza e coerência, interesse público, custos, criatividade, importância para a região ou bairro e para a cidade.

$\S 1^{\circ}$ - A seleção de propostas realizar-se-á anualmente.

$\S 2^{\circ}$ - Serão consideradas preferenciais as propostas culturais de caráter coletivo que estejam em curso e necessitem de recursos para o seu desenvolvimento e consolidação.

Art. 11 - Os programas beneficiados pelo Programa VAI deverão prestar contas durante sua execução e ao final dela para a Secretaria Municipal de Cultura, na forma que ela regulamentar.

Art. 12 - A avaliação do Programa VAI comparará os resultados previstos e efetivamente alcançados, os custos estimados e reais e a repercussão da iniciativa na 
comunidade ou localidade.

Parágrafo único - É necessária a aprovação da prestação de contas para que o beneficiário do programa possa candidatar-se novamente.

Art. 13 - Ao final de cada ano o Conselho Municipal de Cultura realizará uma avaliação coletiva do Programa VAI com a presença dos beneficiários.

Art. 14 - O Executivo deverá regulamentar esta lei no prazo de 60 (sessenta) dias.

Art. 15 - O Programa VAI instituído por esta lei deverá ter dotação orçamentária própria, suplementada se necessário.

Art. 16 - Esta lei entra em vigor na data de sua publicação.

PREFEITURA DO MUNICÍPIO DE SÃO PAULO, aos 24 de março de 2003, $450^{\circ}$ da fundação de São Paulo.

MARTA SUPLICY, PREFEITA

LUIZ TARCISIO TEIXEIRA FERREIRA, Secretário dos Negócios Jurídicos

JOÃO SAYAD, Secretário de Finanças e Desenvolvimento Econômico

CELSO FRATESCHI, Secretário Municipal de Cultura

Publicada na Secretaria do Governo Municipal, em 24 de março de 2003.

RUI GOETHE DA COSTA FALCÃO, Secretário do Governo Municipal 


\section{ANEXO N - edital de primeiras obras - (4 edições)}

\section{Edital de Co-patrocínio para Primeiras Obras}

A Prefeitura do Município de São Paulo, através da Secretaria Municipal de Cultura, torna público que no período de 25 de julho a 10 de setembro de 2007 estará recebendo no Centro Cultural da Juventude, situado na Avenida Deputado Emilio Carlos, 3.641, Vila Nova Cachoeirinha, Zona Norte, nesta Capital, das 13:00 às 17:00 horas, inscrições de propostas dos interessados em participar deste Edital.

\section{OBJETO}

1.1. O presente edital tem por finalidade co-patrocinar a realização de produtos culturais.

1.2. Os projetos que utilizarem recursos multimídia terão prioridade na avaliação da comissão julgadora.

1.3. Considera-se para fim deste edital produto cultural todo trabalho que tem um objeto, obra ou apresentação de natureza artística e cultural.

1.4. Considera-se para fim deste edital que Multimídia é a combinação de pelo menos um tipo de mídia estática (texto, fotografia, gráfico), com pelo menos um tipo de mídia dinâmica (vídeo, áudio, animação, jogos eletrônicos, sites). O termo referese, portanto, a tecnologias com suporte digital para criar, manipular, armazenar e pesquisar conteúdos.

1.5. O produto cultural final deverá ser será o principal destino dos recursos deste Edital.

\section{VALOR E CONDIÇÕES DO INCENTIVO}

2.1. O valor máximo a ser concedido a cada projeto será de $\mathrm{R} \$ 50.000,00$ (cinqüenta mil reais), incluindo as taxas e impostos, que ficarão por conta do selecionado. 
2.2. O valor aprovado será liberado em duas parcelas, da seguinte forma:

a) $70 \%$ (setenta por cento) do aporte, até 20 (vinte) dias após a assinatura do termo de co-patrocínio; e

b) $30 \%$ (trinta por cento) do aporte, 30 (trinta) dias após a entrega do produto.

2.3 O total do recurso disponível para esse edital é de $\mathrm{R} \$ 250.000,00$ (duzentos e cinqüenta mil reais) da dotação 9510.13.392.0227.6365.33903900.00.

2.4 Os direitos autorais morais serão do autor da obra. Os direitos autorais patrimoniais ficam cedidos ao Município de São Paulo para fins não comerciais, por tempo indeterminado.

\section{CONDIÇÕES DE PARTICIPAÇÃO}

3.1. Não poderá se inscrever nem concorrer à seleção de que trata este edital, órgão ou programa da Administração Pública, direta ou indireta, seja ela municipal, estadual ou federal.

3.2. Cada proponente poderá ter somente um projeto selecionado.

3.3. Cada proponente poderá inscrever, no máximo, 2 (dois) projetos nesta seleção.

3.4. Poderão participar desta seleção somente pessoas jurídicas sediadas no Município de São Paulo que atendam a todas as disposições desse Edital, e que não estejam impedidas de contratar com a Administração Pública.

\section{INSCRIÇÕES}

As propostas e os projetos a serem inscritos deverão ser apresentadas no Centro Cultural da Juventude, situado na Avenida Deputado Emilio Carlos, 3.641, Vila Nova Cachoeirinha, Zona Norte, nesta Capital, das 13:00 às 17:00 horas, até o dia 10/09/2007. Cópias simples dos documentos abaixo descritos devem ser apresentados no ato da inscrição: 
4.1. Um único envelope escrito "EDITAL DE CO-PATROCÌNIO PRIMEIRAS OBRAS", o nome do projeto, o nome do proponente e a palavra "DOCUMENTAÇÃO”, contendo:

a) requerimento de inscrição preenchido e assinado (Anexo I)

b) ficha síntese preenchida por completo (Anexo II)

c) cartão de registro no cadastro nacional de pessoa Jurídica - CNPJ

d) cadastro de contribuintes mobiliários - CCM

e) carteira de identidade (fotocópia), do representante legal

f) cadastro de pessoa física (CPF), regular junto a Receita Federal (fotocópia), do representante legal

g) declaração - sob penas da lei - do proponente de que não tem no núcleo artístico responsável pelo projeto nenhum componente que seja funcionário público municipal da Cidade de São Paulo. (anexo III)

h) declaração - sob penas da lei - do proponente de que está sediado no Município de São Paulo nos últimos dois anos. (Anexo IV)

4.2. Os documentos referidos no item 4.1. deste edital devem ser apresentados, nos originais ou fotocópias autenticadas, por ocasião da lavratura do termo de copatrocínio.

4.3. 1 (um) envelope escrito na frente "EDITAL DE CO-PATROCÌNIO PARA PRIMEIRAS OBRAS", o nome do projeto, o nome do proponente e a palavra "PROJETO”, contendo 5 (cinco) cópias dos seguintes documentos:

a) exposição clara do trabalho ou obra final, na qual constem justificativa, objetivo e o produto a ser desenvolvido (no máximo duas laudas);

b) plano de trabalho para a produção, contendo:

I - cronograma detalhado;

II - descrição das atividades a serem desenvolvidas;

III - descrição dos recursos materiais necessários;

IV - orçamento completo e detalhado;

$\mathrm{V}$ - plano de divulgação e apresentação

c) informações complementares que o proponente julgar necessárias para a 
avaliação do projeto (texto ou roteiro, storyboards, letras de música, livros etc.).

d) portfolio e currículo dos principais proponentes ou do grupo.

\section{COMISSÃO DE SELEÇÃO}

5.1. Para a escolhaselecionar os projetos, será nomeada pela Secretaria Municipal da Cultura uma comissão de seleção formada por até 10 (dez) membros com reconhecida competência na área cultural.

5.2. A Secretaria Municipal de Cultura publicará no Diário Oficial da Cidade a composição da Comissão de Seleção.

5.3. Nenhum membro da Comissão de Seleção poderá participar de forma alguma de projeto concorrente ou ter quaisquer vínculos profissionais ou empresariais com as propostas apresentadas, ou de parentesco com os sócios, acionistas e diretores da proponente.

5.4. A comissão de seleção priorizará projetos que se valham de recursos multimídia e terá como critérios para a seleção:

a) a clareza e qualidade da proposta apresentada;

b) a compatibilidade com o objetivo deste edital;

c) a coerência do orçamento com a proposta apresentada;

d) a relevância, pertinência e interesse cultural do produto a ser desenvolvido;

e) o portfólio e currículo do proponente;

f) a diversidade, por linguagem artística e por região da cidade, do conjunto de propostas selecionadas.

5.5. Os critérios de julgamento deverão ser observados pela Comissão de Seleção, que justificará a decisão nas respectivas atas. Na relação dos selecionados a Comissão indicará uma lista suplementar com 3 (três) projetos para casos de eventual desistência ou impossibilidade de contratação.

5.6. A comissão de seleção lavrará em ata o resultado que será publicado pela Secretaria Municipal de Cultura no Diário Oficial da Cidade. 
5.7. A Comissão poderá deixar de utilizar a totalidade dos recursos disponíveis previsto no item 2.3 deste edital se julgar que os projetos apresentados não atendem aos objetivos do edital.

5.8. A Comissão poderá, a seu critério, solicitar esclarecimentos a assessores técnicos.

5.9. A Comissão julgadora decidirá sobre os casos não previstos no edital.

5.10. A Comissão é soberana, não cabendo recurso hierárquico de suas decisões.

\section{PRAZOS}

6.1. Até 30 (trinta) dias após o julgamento dos projetos, a Secretaria Municipal de Cultura deverá notificar os vencedores que terão o prazo de 5 (cinco) dias contados do recebimento da notificação para manifestarem, por escrito, se aceitam ou desistem da realização do produto cultural.

6.2. Em caso de desistência ou problemas de documentação, o Centro Cultural da Juventude terá o prazo de 5 (cinco) dias para notificar novos vencedores, sem prejuízo dos demais selecionados.

6.3. A Secretaria Municipal de Cultura homologará e publicará no Diário Oficial da Cidade a seleção de projetos da Comissão de Seleção e as alterações previstas no item anterior.

6.4. O proponente terá até 4 (quatro) meses para realizar o projeto e entregar o produto cultural, contados da data de assinatura do termo de co-patrocínio.

\section{DO CO-PATROCÍNIO E PAGAMENTO}

7.1 Até 20 dias após cada publicação prevista no item 6.3. O Centro Cultural da Juventude providenciará a lavratura do termo de co-patrocínio para cada projeto. 
7.2 Os responsáveis pelos projetos selecionados deverão apresentar os seguintes documentos para a formalização do termo de co-patrocínio:

a) cópia do cadastro nacional de pessoa jurídica - CNPJ;

b) cópia da inscrição no cadastro de contribuinte mobiliários - CCM;

c) certidão negativa de débitos - CND/INSS;

d) certidão de regularidade fiscal - CRF/FGTS;

e) cópia de certidão negativa de tributos municipais;

f) comprovante de inexistência de pendências no CADIN MUNICIPAL Cadastro Informativo Municipal;

g) contrato social ou estatuto com todas as alterações, com firmas reconhecidas e cópias autenticadas;

h) última ata de eleição da diretoria, com firmas reconhecidas e cópias autenticadas;

i) cópia do cadastro de pessoa física e documento de identificação do responsável legal da empresa;

7.3. O projeto selecionado para o co-patrocínio somente poderá ser alterado mediante autorização da Comissão de Seleção.

\section{DA PRESTAÇÃO DE CONTAS}

8.1. O partícipe (pessoa jurídica) do projeto deverá apresentar ao Centro Cultural da Juventude prestação de contas no prazo de até 30 (trinta) dias do recebimento da última parcela, comprovando a utilização dos recursos conforme o projeto apresentado.

8.2. As despesas serão comprovadas mediante documentos originais fiscais ou equivalentes (ou cópias acompanhadas do original para certificação pelos funcionários responsáveis).

8.3. As faturas, os recibos, notas fiscais e quaisquer outros documentos comprobatórios deverão ser emitidos em nome do partícipe do projeto, devidamente identificados com referência ao nome do projeto. 
8.4. A prestação de contas será analisada pelo setor técnico do Centro Cultural da Juventude e submetida à aprovação pela Secretaria Municipal de Cultura.

8.5. O Centro Cultural da Juventude oferecerá, na sua sede, orientações para a prestação de contas, na data e horário agendado previamente com os partícipes.

8.6. A não aprovação da prestação de contas do projeto na forma estabelecida no item anterior sujeitará o partícipe a devolver o total das importâncias recebidas, acrescidas da respectiva atualização monetária, e multa prevista neste edital (9.4) em até 30 (trinta) dias da publicação do despacho que as rejeitou.

8.7. A não devolução da importância no prazo e forma assinalados caracterizará a inadimplência do partícipe, de seus responsáveis legais, que ficam impedidos de firmar novos projetos ou contratos com a Municipalidade ou receber qualquer apoio dos órgãos municipais.

8.8. As responsabilidades civis, penais, comerciais, e outras advindas de utilização de direitos autorais e/ou patrimoniais anteriores, contemporâneas ou posteriores à formalização do termo de copatrocínio cabem exclusivamente ao partícipe.

8.9. A Secretaria Municipal de Cultura não se responsabilizará em hipótese alguma pelos atos, contratos ou compromissos assumidos de natureza comercial, financeira, trabalhista ou outra, realizado pelo partícipe para fins do cumprimento do termo de co-patrocínio com a Prefeitura do Município de São Paulo (Secretaria Municipal de Cultura).

\section{PENALIDADES}

9.1. O partícipe que durante a execução alterar as características do projeto selecionado, sem prévia autorização do Centro Cultural da Juventude estará sujeito ao imediato bloqueio da liberação da próxima parcela e, se o projeto não for reconduzido às características com as quais foi apresentado, dentro do prazo contratualmente 
estabelecido, à rescisão do termo de co-patrocínio, com a conseqüente devolução dos valores recebidos, corrigidos monetariamente a contar da data do recebimento.

9.2. O não cumprimento do projeto tornará inadimplente o partícipe, seus responsáveis legais e os membros do núcleo artístico, que, uma vez assim declarados, não poderão efetuar qualquer contrato ou receber qualquer apoio dos órgãos municipais por um período de cinco anos.

9.3. O partícipe, que tiver na sua equipe técnica ou artística do projeto integrante que seja funcionário público municipal, terá o projeto desclassificado e o integrante estará sujeito às sanções previstas no Estatuto do Servidor Público Municipal.

9.4. O partícipe inadimplente será obrigado a devolver o total da importância recebida no Projeto, acrescida da respectiva atualização monetária e estará sujeito à aplicação de multa no valor de até $50 \%$ (cinqüenta por cento) do valor do copatrocínio.

9.5. O partícipe que descumprir as demais obrigações que lhe são cometidas pelo termo de co-patrocínio estará sujeito à:

a) rescisão do termo de co-patrocínio com a conseqüente devolução dos valores recebidos, corrigidos monetariamente a contar da data do recebimento além da multa prevista no item 9.4;

b) ser declarado inidôneo para licitar ou contratar ou receber qualquer apoio da Administração Pública, pelo prazo mínimo de cinco anos e enquanto perdurarem os motivos determinantes da punição ou até que seja promovida a reabilitação perante o órgão que aplicou a penalidade, que só será concedida se o partícipe ressarcir a Administração pelos prejuízos resultantes.

9.6. Aplicam-se a este capítulo, no que couber, as disposições dos artigos 54 e 55 do Decreto Municipal $n^{\circ} 44.279 / 03$, combinados com o $\S 1^{\circ}$ do artigo 15 do Decreto Municipal no 46.888/06. 


\section{DISPOSIÇÕES FINAIS}

10.1. Os projetos não selecionados ficarão à disposição do proponente pelo prazo de 20 (vinte) dias contados da divulgação final da seleção no Diário Oficial do Município de São Paulo. Após essa data serão eliminados a critério do Centro Cultural da Juventude.

10.2. Cópia deste edital e seus anexos poderá ser encontrada no site do Centro Cultural da Juventude (http://centrodajuventude.prefeitura.sp.gov.br), ou no site da Secretaria Municipal de Cultura (http://www.prefeitura.sp.gov.br/cultura).

10.3. Eventuais dúvidas sobre o edital deverão ser formalmente encaminhadas por escrito ao Centro Cultural da Juventude até 5 (cinco) dias antes do encerramento das inscrições

Prefeitura do Município de São Paulo

Secretaria Municipal de Cultura

Centro Cultural da Juventude

São Paulo,

Publique-se.

Paulo Rodrigues

Respondendo pelo expediente da Secretaria Municipal de Cultura

ANEXO I - Modelo de requerimento de inscrição

São Paulo, de de

Secretaria Municipal de Cultura de São Paulo

Exmo. Sr. Secretário

Referência: "Produção Cultural - Primeiras Obras".

Edital N. ${ }^{\circ}$ 
Projeto

Proponente

(nome pessoa Juridica -

proponente do projeto), inscrita no CNPJ n. ${ }^{\circ}$

com sede à (endereço

completo, cep, telefone) aqui representado pelo Sr. (representante legal) portador da Cédula de Identidade

RG

N. ${ }^{\circ}$

e

$\mathrm{CPF}$

n. ${ }^{\circ}$ venho requerer a inscrição do Projeto denominado de acordo com a exigência do Edital publicado no Diário Oficial do Município de São Paulo do dia de de 2007.

Envio, anexos, o "Projeto" e a documentação exigidos neste Edital, de cujos termos declaro estar ciente e de acordo.

Atenciosamente,

Nome e assinatura do proponente

ANEXO II- FICHA SÍNTESE

Nome do projeto:

Razão Social da Proponente:

Nome do representante legal:

Telefones:

Sede: I

Representante legal:

E-mail: 
Subprefeitura e bairro de localização da Proponente:

Bairro: Subprefeitura:

Tempo de existência com CNPJ (em anos):

Objeto ou Área(s) de Atuação da Proponente (conforme Contrato Social):

Possui outras formas de apoio/financiamento? ( ) Sim ( ) Não - Se SIM, preencha o campo abaixo:

( ) Órgão Público, Qual(is)?

( ) Iniciativa Privada, Qual(is)?

Nome dos integrantes do grupo executor do projeto:

$1-$

Idade:

2

Idade:

3

Idade:

4

Idade:

5

Idade:

6

Idade:

7

Idade:

8

Idade:

9

Idade:

10 
Idade:

Assinale o produto previsto no projeto:

( ) Exibição (filmes, videos, audiovisuais, multimídia)

( ) Distribuição (livros, Cd’s, DVD’s, outras mídias)

( ) Exposição

( ) Apresentação de Espetáculo

( ) Eventos

( ) Filme

( ) Outros. Quais?

Custo total do projeto: $\mathrm{R} \$$

Prazo de realização do projeto: (período, meses)

Breve Descrição do produto

Breve Descrição da Contrapartida para a Cidade de São Paulo da Proposta DO PONTO DE VISTA DO VALOR CULTURAL

RESUMO DO ORÇAMENTO

\begin{tabular}{|c|c|}
\hline $\begin{array}{l}\text { 1-DESPESAS } \\
\text { PRODUÇÃO }\end{array}$ & $\mathrm{R} \$$ \\
\hline 2-DESPESAS DE PRODUÇÃO & $\mathrm{R} \$$ \\
\hline $\begin{array}{ll}\text { 3-DESPESAS } & \text { DE }\end{array}$ & $\mathrm{R} \$$ \\
\hline DIVULGAÇÃO (LIMITADA A 10\% DA & \\
\hline SOMATÓRIA DAS DESPESAS DE & \\
\hline PRÉ PRODUÇÃO E PRODUÇÃO ATÉ & \\
\hline O MAXIMO DE R $\$ 15.000,00$ DO & \\
\hline PROJETO) & \\
\hline 4-DESPESAS & $\mathrm{R} \$$ \\
\hline
\end{tabular}




\begin{tabular}{|c|c|}
\hline $\begin{array}{l}\text { ADMINISTRAÇÃO (LIMITADA A } \\
\text { 10\% DA SOMATÓRIA DOS ITENS DE } \\
\text { PRÉ PRODUÇÃO E PRODUÇÃO DO } \\
\text { PROJETO }\end{array}$ & \\
\hline \begin{tabular}{l}
\multicolumn{1}{c}{ 5-VALOR DE } \\
AGENCIAMENTO (LIMITADA A $10 \%$ \\
DA SOMATÓRIA DAS DESPESAS DE \\
PRÉ PRODUÇÃO E PRODUÇÃO DO \\
PROJETO, ATÉ O MAXIMO DE R\$ \\
$15.000,00)$
\end{tabular} & $\mathrm{R} \$$ \\
\hline
\end{tabular}

\section{É OBRIGATÓRIO O PREENCHIMENTO COMPLETO DESTA FICHA}

\section{ANEXO III - MODELO DE DECLARAÇÃO}

São Paulo, de de 2007.

(nome pessoa Juridica -

proponente do projeto), inscrita no CNPJ n. ${ }^{\circ}$

com sede à

(endereço

completo, cep, telefone) aqui representado pelo $\mathrm{Sr}$. (representante legal) portador da Cédula de Identidade

RG $\mathrm{n}^{\circ}-$ e CPF

n. ${ }^{\circ}$ DECLARA(M), sob as penas da lei, que não tenho na equipe técnica ou artística responsável pelo projeto de que trata o "Edital de Produção Cultural - Primeiras Obras" nenhum componente que seja funcionário público municipal da Cidade de São Paulo.

assinatura do(s) representante(s) legal(is)

ANEXO IV - DECLARAÇÃO DE SEDE NO MUNICÍPIO DE SÃO PAULO/PESSOA JURÍDICA 
D E C LAR A Ç Ã O

$\mathrm{Eu}$,

(Nome do representante legal da pessoa jurídica)

RG $\mathrm{CPF}$ declaro, sob as penas da lei, para fins de seleção do Edital de Produção Cultural, que (nome da pessoa jurídica) tem sede no município de São Paulo há mais de 2 (dois) anos.

São Paulo, de de 2007

(assinatura)

\section{Edital nº 02/08/CCJ - Co-patrocínio para Primeiras Obras.}

A Prefeitura do Município de São Paulo, através da Secretaria Municipal de Cultura, torna público que no período de 29 de abril a 15 de maio de 2008 estará recebendo no Centro Cultural da Juventude, situado na Avenida Deputado Emilio Carlos, 3.641, Vila Nova Cachoeirinha, Zona Norte, nesta Capital, de terça a sábado, das 13:00 às 17:00 horas, inscrições de propostas dos interessados em participar deste Edital.

1. OBJETO

1.1. O presente edital tem por finalidade co-patrocinar a realização de produtos culturais.

1.2. Os projetos que utilizarem recursos multimídia terão prioridade na avaliação da comissão julgadora.

1.3. Considera-se como produto cultural, para fim deste edital, todo trabalho que tem um objeto, obra ou apresentação de natureza artística e cultural.

1.4. Considera-se para fim deste edital que Multimídia é a combinação de pelo 
menos um tipo de mídia estática (texto, fotografia, gráfico), com pelo menos um tipo de mídia dinâmica (vídeo, áudio, animação, jogos eletrônicos, sites). O termo referese, portanto, a tecnologias com suporte digital para criar, manipular, armazenar e pesquisar conteúdos.

1.5. O produto cultural final deverá ser o principal destino dos recursos deste Edital.

\section{VALOR E CONDIÇÕES DO INCENTIVO}

2.1. O valor máximo a ser concedido a cada projeto cujo proponente seja pessoa jurídica será de $\mathrm{R} \$ 50.000,00$ (cinqüenta mil reais), incluindo as taxas e impostos, que ficarão por conta do selecionado.

2.2. O valor máximo a ser concedido a cada projeto cujo proponente seja pessoa física será de $\mathrm{R} \$ 30.000,00$ (trinta mil reais), incluindo as taxas e impostos, que ficarão por conta do selecionado.

2.3. O valor aprovado será liberado em duas parcelas, da seguinte forma:

2.3.1. $70 \%$ (setenta por cento) do aporte, até 30 (vinte) dias após a assinatura do termo de copatrocínio; e

2.3.2. $30 \%$ (trinta por cento) do aporte, 30 (trinta) dias após a entrega do produto.

2.3.3. O total de recursos disponível para esse edital é de $\mathrm{R} \$ 480.000,00$, sendo R\$ 180.000,00 da dotação 9510.13.392.0227.6365.33903600.00 e de R\$ 300.000,00 da dotação 9510.13.392.0227.6365.33903900.00.

2.4. Os direitos autorais morais serão do autor da obra. Os direitos autorais patrimoniais ficam cedidos ao Município de São Paulo para fins não comerciais, por tempo indeterminado.

2.5. Este Edital atenderá até 6 projetos, no máximo.

\section{CONDIÇÕES DE PARTICIPAÇÃO}


3.1. Não poderá se inscrever nem concorrer à seleção de que trata este edital, órgão ou programa da Administração Pública, direta ou indireta, seja ela municipal, estadual ou federal.

3.2. Cada proponente poderá ter somente um projeto selecionado.

3.3. Cada proponente poderá inscrever, no máximo, 2 (dois) projetos nesta seleção.

3.4. Poderão participar desta seleção somente pessoas jurídicas ou pessoas físicas sediadas ou residentes no Município de São Paulo que atendam a todas as disposições desse Edital, e que não estejam impedidas de contratar com a Administração Pública. 3.4.1 Na hipótese de pessoa jurídica constituída a menos de dois anos, serão aceitas nesta seleção as inscrições de projetos, desde que seja comprovada a residência dos respectivos sócios no Município de São Paulo no prazo previsto neste edital.

\section{INSCRIÇÕES}

As propostas e os projetos a serem inscritos deverão ser apresentadas no Centro Cultural da Juventude, situado na Avenida Deputado Emilio Carlos, 3.641, Vila Nova Cachoeirinha, Zona Norte, nesta Capital, de terça a sábado, das 13:00 às 17:00 horas, de 29 de abril a 15 de maio de 2008. No ato da inscrição, o proponente deverá entregar dois envelopes, no formato A3, com as inscrições . "EDITAL nº 02/08 - CCJ - CO-PATROCÌNIO - PRIMEIRAS OBRAS", o nome do projeto, o nome do proponente. O primeiro deverá conter ainda a palavra "DOCUMENTAÇÃO"; o segundo deverá conter a palavra "PROJETO".

4.1. No ato da inscrição, o primeiro envelope, com a palavra “DOCUMENTAÇÃO”, será conferido e o projeto somente será considerado inscrito se este envelope contiver todos os documentos descriminados abaixo, em cópias simples:

a) requerimento de inscrição preenchido e assinado (Anexo I); 
b) ficha síntese preenchida por completo (Anexo II);

c) cartão de registro no cadastro nacional de pessoa Jurídica - CNPJ, se pessoa jurídica ;

d) cadastro de pessoa física (CPF), regular junto a Receita Federal (fotocópia), do representante legal, se pessoa jurídica, ou do proponente, se pessoa física;

e) cadastro de contribuintes mobiliários - CCM, pessoa física ou jurídica;

f) carteira de identidade (fotocópia), do representante legal, se pessoa jurídica ou do proponente, se pessoa física;

g) declaração - sob penas da lei - do proponente de que não é funcionário público do Município de São Paulo, se pessoa física ou de que não tem no núcleo artístico responsável pelo projeto nenhum componente que o seja, no caso de pessoa jurídica (anexo III);

h) comprovante do proponente de que reside ou está sediado no Município de São Paulo nos últimos dois anos. Na hipótese de pessoa jurídica constituída a menos de dois anos, comprovante de residência dos respectivos sócios no Município de São Paulo no prazo mencionado.

4.2. Os documentos referidos no item 4.1. deste edital devem ser reapresentados, nos originais ou fotocópias autenticadas, por ocasião da lavratura do termo de co-patrocínio.

4.3. O segundo envelope, com a palavra "PROJETO", deverá estar lacrado e conter 5 (cinco) cópias dos seguintes documentos:

a) exposição clara do trabalho ou obra final, na qual constem justificativa, objetivo e o

produto a ser desenvolvido (no máximo duas laudas);

b) plano de trabalho para a produção, contendo:

I - cronograma detalhado;

II - descrição das atividades a serem desenvolvidas;

III - descrição dos recursos materiais necessários;

IV - orçamento completo e detalhado;

$\mathrm{V}$ - plano de divulgação e apresentação

c) informações complementares que o proponente julgar necessárias para a 
avaliação do projeto (texto ou roteiro, storyboards, DVD's, CD's, Fotos, livros, etc.).

d) portfolio e currículo dos principais componentes do grupo ou do proponente.

4.4. O não cumprimento dessas instruções acarretará na automática desclassificação do projeto.

\section{COMISSÃO DE SELEÇÃO}

5.1. Para selecionar os projetos, será nomeada pela Secretaria Municipal da Cultura uma comissão de seleção formada por até 10 (dez) membros com reconhecida competência na área cultural.

5.2. A Secretaria Municipal de Cultura publicará no Diário Oficial da Cidade a composição da Comissão de Seleção.

5.3. Nenhum membro da Comissão de Seleção poderá participar de forma alguma de projeto concorrente ou ter quaisquer vínculos profissionais ou empresariais com as propostas apresentadas, ou de parentesco com os sócios, acionistas e diretores da proponente.

5.4. A comissão de seleção priorizará projetos que se valham de recursos multimídia e terá como critérios para a seleção:

a) a clareza e qualidade da proposta apresentada;

b) a compatibilidade com o objetivo deste edital;

c) a coerência do orçamento com a proposta apresentada;

d) a relevância, pertinência e interesse cultural do produto a ser desenvolvido;

e) o portfolio e currículo do proponente;

f) a diversidade, por linguagem artística e por região da cidade, do conjunto de propostas selecionadas.

5.5. Os critérios de julgamento deverão ser observados pela Comissão de Seleção, que

justificará a decisão nas respectivas atas. $\mathrm{Na}$ relação dos selecionados a 
Comissão indicará uma lista suplementar com 3 (três) projetos para casos de eventual desistência ou impossibilidade de contratação.

5.6. A comissão de seleção lavrará em ata o resultado que será publicado pela Secretaria Municipal de Cultura no Diário Oficial da Cidade.

5.7. A Comissão poderá deixar de utilizar a totalidade dos recursos disponíveis previsto no item 2.3 deste edital se julgar que os projetos apresentados não atendem aos objetivos do edital.

5.8. A Comissão poderá, a seu critério, solicitar esclarecimentos a assessores técnicos.

5.9. A Comissão julgadora decidirá sobre os casos não previstos no edital.

5.10. A Comissão é soberana, não cabendo recurso hierárquico de suas decisões.

\section{PRAZOS}

6.1. Até 30 (trinta) dias após o julgamento dos projetos, a Secretaria Municipal de Cultura deverá notificar os vencedores que terão o prazo de 5 (cinco) dias contados do recebimento da notificação para manifestarem, por escrito, se aceitam ou desistem da realização do produto cultural.

6.2. Em caso de desistência ou problemas de documentação, o Centro Cultural da Juventude terá o prazo de 5 (cinco) dias para notificar novos vencedores, sem prejuízo dos demais selecionados.

6.3. A Secretaria Municipal de Cultura homologará e publicará no Diário Oficial da Cidade a seleção de projetos da Comissão de Seleção e as alterações previstas no item anterior.

6.4. O proponente terá até 5 (cinco) meses para realizar o projeto e entregar o 
produto cultural, contados da data de assinatura do termo de co-patrocínio.

\section{DO CO-PATROCÍNIO E PAGAMENTO}

7.1 Até 20 dias após cada publicação prevista no item 6.3. O Centro Cultural da Juventude providenciará a lavratura do termo de co-patrocínio para cada projeto.

7.2 Os responsáveis pelos projetos selecionados deverão apresentar os seguintes documentos para a formalização do termo de co-patrocínio:

a) cópia do cadastro nacional de pessoa jurídica - CNPJ ou do cadastro de pessoa física - CPF, junto à Receita Federal;

b) cópia da inscrição no cadastro de contribuinte mobiliários - CCM;

c) certidão negativa de débitos - CND/INSS; se pessoa jurídica ou número de inscrição na autarquia, se pessoa física;

d) certidão de regularidade fiscal - CRF/FGTS, se pessoa jurídica;

e) cópia de certidão negativa de tributos municipais;

f) comprovante de inexistência de pendências no CADIN MUNICIPAL Cadastro Informativo Municipal;

g) contrato social ou estatuto com todas as alterações, com firmas reconhecidas e cópias autenticadas, se pessoa jurídica;

h) última ata de eleição da diretoria, com firmas reconhecidas e cópias autenticadas, se pessoa jurídica;

i) cópia do cadastro de pessoa física e documento de identificação do responsável legal da empresa;

j) número da agência e conta bancária aberta exclusivamente para a realização do projeto, no Banco Bradesco S.A, conforme determina o Decreto Municipal $\mathrm{n}^{\circ}$ 46.528 , de 20/10/2005.

7.3. O projeto selecionado para o co-patrocínio somente poderá ser alterado mediante autorização da Comissão de Seleção.

\section{DA PRESTAÇÃO DE CONTAS}

8.1. O partícipe (pessoa jurídica ou fisica) do projeto deverá apresentar ao Centro Cultural da Juventude prestação de contas no prazo de até 30 (trinta) dias do 
recebimento da última parcela, comprovando a utilização dos recursos conforme o projeto apresentado.

8.2. O partícipe fornecerá cópia do extrato bancário mensal relativo à conta bancária exclusiva para o projeto.

8.3. As despesas serão comprovadas mediante documentos originais fiscais ou equivalentes (ou cópias acompanhadas do original para certificação pelos funcionários responsáveis).

8.4. As faturas, os recibos, notas fiscais e quaisquer outros documentos comprobatórios deverão ser emitidos em nome do partícipe do projeto, devidamente identificados com referência ao nome do projeto.

8.5. A prestação de contas será analisada pelo setor técnico do Centro Cultural da Juventude e submetida à aprovação pela Secretaria Municipal de Cultura.

8.6. O Centro Cultural da Juventude oferecerá, na sua sede, orientações para a prestação de contas, na data e horário agendado previamente com os partícipes.

8.7. A não aprovação da prestação de contas do projeto na forma estabelecida no item anterior sujeitará o partícipe a devolver o total das importâncias recebidas, acrescidas da respectiva atualização monetária, e multa prevista neste edital (9.4) em até 30 (trinta) dias da publicação do despacho que as rejeitou.

8.8. A não devolução da importância no prazo e forma assinalados caracterizará a inadimplência do partícipe, de seus responsáveis legais, que ficam impedidos de firmar novos projetos ou contratos com a Municipalidade ou receber qualquer apoio dos órgãos municipais.

8.9. As responsabilidades civis, penais, comerciais, e outras advindas de utilização de direitos autorais e/ou patrimoniais anteriores, contemporâneas ou posteriores à formalização do termo de co-patrocínio cabem exclusivamente ao 
partícipe.

8.10. A Secretaria Municipal de Cultura não se responsabilizará em hipótese alguma pelos atos, contratos ou compromissos assumidos de natureza comercial, financeira, trabalhista ou outra, realizado pelo partícipe para fins do cumprimento do termo de co-patrocínio com a Prefeitura do Município de São Paulo (Secretaria Municipal de Cultura).

\section{PENALIDADES}

9.1. O partícipe que durante a execução alterar as características do projeto selecionado, sem prévia autorização do Centro Cultural da Juventude estará sujeito ao imediato bloqueio da liberação da próxima parcela e, se o projeto não for reconduzido às características com as quais foi apresentado, dentro do prazo contratualmente estabelecido, à rescisão do termo de co-patrocínio, com a conseqüente devolução dos valores recebidos, corrigidos monetariamente a contar da data do recebimento.

9.2. O não cumprimento do projeto tornará inadimplente o partícipe, seus responsáveis legais e os membros do núcleo artístico, que, uma vez assim declarados, não poderão efetuar qualquer contrato ou receber qualquer apoio dos órgãos municipais por um período de cinco anos.

9.3. O partícipe, pessoa jurídica, que tiver na sua equipe técnica ou artística do projeto integrante que seja funcionário público municipal, terá o projeto desclassificado e o integrante estará sujeito às sanções previstas no Estatuto do Servidor Público Municipal.

9.4. O partícipe inadimplente será obrigado a devolver o total da importância recebida no Projeto, acrescida da respectiva atualização monetária e estará sujeito à aplicação de multa no valor de até $50 \%$ (cinqüenta por cento) do valor do copatrocínio.

9.5. O partícipe que descumprir as demais obrigações que lhe são cometidas pelo termo de copatrocínio estará sujeito à: 
a) rescisão do termo de co-patrocínio com a conseqüente devolução dos valores recebidos, corrigidos monetariamente a contar da data do recebimento além da multa prevista no item 9.4;

b) ser declarado inidôneo para licitar ou contratar ou receber qualquer apoio da Administração Pública, pelo prazo mínimo de cinco anos e enquanto perdurarem os motivos determinantes da punição ou até que seja promovida a reabilitação perante o órgão que aplicou a penalidade, que só será concedida se o partícipe ressarcir a Administração pelos prejuízos resultantes.

9.6. Aplicam-se a este capítulo, no que couber, as disposições dos artigos 54 e 55 do Decreto Municipal $n^{\circ} 44.279 / 03$, combinados com o $\S 1^{\circ}$ do artigo 15 do Decreto Municipal no 46.888/06.

\section{DISPOSIÇÕES FINAIS}

10.1. Os projetos não selecionados ficarão à disposição do proponente pelo prazo de 20 (vinte) dias contados da divulgação final da seleção no Diário Oficial do Município de São Paulo. Após essa data serão eliminados a critério do Centro Cultural da Juventude.

10.2. Cópia deste edital e seus anexos poderá ser encontrada no site do Centro Cultural da Juventude (http://centrodajuventude.prefeitura.sp.gov.br), ou no site da Secretaria Municipal de Cultura (http://www.prefeitura.sp.gov.br/cultura).

10.3. Eventuais dúvidas sobre o edital deverão ser formalmente encaminhadas por escrito ao Centro Cultural da Juventude até 5 (cinco) dias antes do encerramento das inscrições

Prefeitura do Município de São Paulo

Secretaria Municipal de Cultura

Centro Cultural da Juventude

São Paulo,

Publique-se. 


\section{ANEXO I - Modelo de requerimento de inscrição}

São Paulo, de de

Secretaria Municipal de Cultura de São Paulo

Exmo. Sr. Secretário

Referência: "Produção Cultural - Primeiras Obras".

Edital $^{\circ}{ }^{0}$ 02/2008/CCJ. ${ }^{\circ}$

Projeto

Proponente

(nome

pessoa

física/jurídica - proponente do projeto), inscrita no $\mathrm{CNPJ} / \mathrm{CPF}$ n. ${ }^{\circ}$ residente/com sede à

(endereço completo, cep, telefone) (aqui representado pelo $\mathrm{Sr}$. (representante legal)

portador da Cédula de Identidade RG N. $\mathrm{e}$ $\mathrm{CPF}$ n. , se pessoa jurídica) venho requerer a inscrição do Projeto denominado , de acordo com a exigência do Edital publicado no Diário Oficial do Município de São Paulo do dia de de 2007.

Envio, anexos, o "Projeto" e a documentação exigidos neste Edital, de cujos termos declaro estar ciente e de acordo.

Atenciosamente,

Nome e assinatura do proponente 


\section{ANEXO II- FICHA SÍNTESE}

Nome do projeto:

Nome/Razão Social da Proponente:

Nome do representante legal, se pessoa jurídica:

Telefones:

Endereço/Sede:

Representante legal, se pessoa jurídica

E-mail:

Subprefeitura e bairro de localização da Proponente:

Bairro: Subprefeitura:

Tempo de existência com CNPJ (em anos), se pessoa jurídica:

Objeto ou Área(s) de Atuação da Proponente:

Possui outras formas de apoio/financiamento? ( ) Sim ( ) Não - Se SIM, preencha o campo abaixo:

( ) Órgão Público, Qual(is)?

( ) Iniciativa Privada, Qual(is)

Nome dos integrantes do grupo executor do projeto, se pessoa jurídica:

$1-$ Idade:

2 Idade:

$3-$ Idade:

4 Idade:

$5-$ Idade:

6 Idade:

$7-$ Idade:

8 Idade:

9 Idade:

10 Idade: 
Assinale o produto previsto no projeto:

( ) Exibição (filmes, videos, audiovisuais, multimídia)

( ) Distribuição (livros, Cd’s, DVD’s, outras mídias)

( ) Exposição

( ) Apresentação de Espetáculo

( ) Eventos

( ) Filme

( ) Outros. Quais?

Custo total do projeto: $\mathrm{R} \$$

Prazo de realização do projeto: (período, meses)

Breve Descrição do produto

Breve Descrição da Contrapartida para a Cidade de São Paulo da Proposta DO PONTO DEVISTA DO VALOR CULTURAL

RESUMO DO ORÇAMENTO

\begin{tabular}{|c|c|}
\hline $\begin{array}{l}\text { 1-DESPESAS } \text { DE PRÉ } \\
\text { PRODUÇÃO }\end{array}$ & $\mathrm{R} \$$ \\
\hline 2-DESPESAS DE PRODUÇÃO & $\mathrm{R} \$$ \\
\hline 3-DESPESAS & $\mathrm{R} \$$ \\
\hline DIVULGAÇÃO (LIMITADA A 10\% DA & \\
\hline SOMATÓRIA DASDESPESAS DE PRÉ & \\
\hline PRODUÇÃO E PRODUÇÃO ATÉ O & \\
\hline MAXIMO $\quad \mathrm{DE} \quad \mathrm{R} \$ 15.000,00 \quad \mathrm{DO}$ & \\
\hline PROJETO) & \\
\hline 4-DESPESAS & $\mathrm{R} \$$ \\
\hline ADMINISTRAÇÃO (LIMITADA A & \\
\hline
\end{tabular}




\begin{tabular}{|l|r|}
\hline $\begin{array}{l}\text { 10\% DA SOMATÓRIA DOS ITENS DE } \\
\text { PRÉ PRODUÇÃO E PRODUÇÃO DO } \\
\text { PROJETO }\end{array}$ & \\
\hline 5-VALOR & R $\$$ \\
AGENCIAMENTO (LIMITADA A $10 \%$ & \\
DA SOMATÓRIA DASDESPESAS DE & \\
PRÉ PRODUÇÃO E PRODUÇÃO DO & \\
PROJETO, ATÉ O MAXIMO DE R\$ & \\
15.000,00)
\end{tabular}

É OBRIGATÓRIO O PREENCHIMENTO COMPLETO DESTA FICHA

\section{ANEXO III - MODELO DE DECLARAÇÃO}

São Paulo, de de 2008.

$\begin{array}{ccccccc} & & & & \text { (nome pessoa física/juridica } & - \\ \text { proponente do } & \text { projeto), } & \text { inscrita } & \text { no } & \text { CPF/CNPJ } & \text { n. }{ }^{\text {o }} \\ & & & \text { residente/com } & \text { sede } & \text { à } \\ & & & \text { (endereço completo, cep, }\end{array}$

telefone) (aqui representado pelo $\mathrm{Sr}$. (representante legal) portador da Cédula de Identidade $\mathrm{RG} \mathrm{n}^{\mathrm{o}}$

e CPF n. ${ }^{\circ}$ se pessoa jurídica) DECLARA, sob as penas da lei, que não é funcionário público do Município de São Paulo (se pessoa física)/ que não tem na equipe técnica ou artística responsável pelo projeto de que trata o "Edital de Produção Cultural - Primeiras Obras" nenhum componente que seja funcionário público do Município de São Paulo (se pessoa jurídica).

assinatura(s) do proponente/representante(s) legal(is)

MINISTÉRIO DA CULTURA

SECRETARIA DO AUDIOVISUAL 


\section{EDITAL DE CONCURSO Nº 26, DE 16 DE SETEMBRO DE 2009}

O Ministério da Cultura - MinC, no âmbito do Programa Mais Cultura, por meio da Secretaria do Audiovisual - SAV e da Secretaria de Articulação Institucional - SAI, em parceria com a Associação Brasileira de Canais Comunitários - ABCCom e com a Sociedade dos Amigos da Cinemateca, torna público o Concurso de Apoio à Produção de Obras Audiovisuais Digitais Inéditas, de CURTA METRAGEM, nos gêneros DOCUMENTÁRIO ou TELERREPORTAGEM, sobre o tema "Cultura e Transformação Social", intitulado "NÓS NA TELA", destinado exclusivamente a pessoas físicas integrantes ou egressas de projetos sociais que desenvolvam atividades de formação para realização de obras audiovisuais, desenvolvidos por entidades sem fins lucrativos, nas condições e exigências estabelecidas neste Edital, em conformidade com a Lei no 8.666, de 21 de junho de 1993.

\section{DO OBJETO}

Apoiar a produção de obras audiovisuais digitais inéditas de curta metragem, sobre o tema "Cultura e Transformação Social", com duração de 15 (quinze) minutos, exclusivamente para integrantes ou egressos de projetos sociais que desenvolvam atividades de formação para realização de obras audiovisuais.

\section{DA PARTICIPAÇÃO}

2.1 Somente poderão concorrer ao presente concurso PESSOAS FÍSICAS, com idades entre 17 (dezessete) e 29 (vinte e nove) anos, com comprovação de ser integrante ou egresso de projetos sociais que desenvolvam atividades de formação para realização de obras audiovisuais e que se apresente como diretor ou diretor e roteirista.

2.1.1 A responsabilidade quanto à comprovação de que o concorrente foi ou é integrante de projeto social será apresentada por documento firmado pelo responsável de entidade sem fins lucrativos, que desenvolva atividades de formação para realização de obras audiovisuais.

2.1.2 O Requerimento de Inscrição (Anexo I) e o Projeto Técnico deverão ser encaminhados no mesmo envelope, por meio dos serviços de postagem de correspondência da Empresa Brasileira de Correios e Telégrafos - ECT, na modalidade de SEDEX, no período de 16 DE SETEMBRO a 03 DE NOVEMBRO 
DE 2009, fazendo constar no endereçamento do envelope os seguintes dados:

NÓS NA TELA

Cinemateca Brasileira

Largo Senador Raul Cardoso, n. 207

CEP: 04021-070

São Paulo - SP

2.1.3 A Concorrente deverá fazer constar no envelope, no espaço destinado ao remetente, além de seu nome e endereço completo, o NOME DO PROJETO e EMAIL, para confirmação do recebimento da correspondência.

2.1.4 É admitida a inscrição de projeto de co-autoria de dois ou mais autores, mas apenas um deles deve se apresentar como responsável pelo projeto, observado o disposto no subitem 2.1 deste edital.

2.2 - O prazo de vigência deste edital será de 16 (dezesseis) meses, contados a partir da homologação do resultado final, prorrogável a critério da Secretaria do Audiovisual do Ministério da Cultura (SAv/MinC) uma única vez, por até 16 (dezesseis) meses.

\section{DOS DOCUMENTOS E DO PROJETO TÉCNICO}

3.1 O Requerimento de Inscrição (Anexo I) deve ser encaminhado em 1 (uma) via, com todos os campos preenchidos, devidamente assinado e em separado do Projeto Técnico, acompanhado da seguinte documentação:

Comprovante de residência no Brasil há pelo menos 02 (dois) anos (contas de água, luz, telefone, IPTU, ou extrato bancário);

Fotocópia de RG e CPF.

3.2 O PROJETO TÉCNICO deverá ser encaminhado em 7 (sete) vias, contendo os documentos abaixo relacionados:

a) Justificativa, com no máximo 25 (vinte e cinco) linhas;

b) Argumento ou sinopse, com lista de possíveis entrevistados, locações e outras informações relevantes para a compreensão da proposta;

c) Orçamento detalhado, com custo global de produção e cópias, conforme previsto no subitem 8.1, alínea “a”, de $\mathrm{R} \$ 30.000,00$ (trinta mil reais), dividido por 
etapas de pré-produção, produção e finalização, contendo a descrição das respectivas despesas, seus quantitativos, custos unitários e totais, com no máximo 4 (quatro) laudas;

d) currículo do(s) realizador(es).

3.3 Os documentos acima citados deverão ser formatados e impressos em papel A4, margem esquerda de $2,5 \mathrm{~cm}$ e direita de $1,5 \mathrm{~cm}$, entrelinhas de $1,5 \mathrm{~cm}$ e fonte tamanho 12 (doze), contendo a citação expressa de seus respectivos títulos, com laudas sequencialmente numeradas e rubricadas.

3.4 Cada concorrente poderá apresentar um único projeto como autor ou como co-autor.

\section{DOS IMPEDIMENTOS E MOTIVOS PARA INDEFERIMENTO DA} INSCRIÇÃO

4.1 A falta de apresentação de quaisquer dos documentos ou a apresentação em desacordo com o estabelecido no item 3 implicará o imediato indeferimento da inscrição.

4.2 A apresentação de orçamento em valor superior a $\mathrm{R} \$ 30.000,00$ (trinta mil reais) implicará o imediato indeferimento da inscrição.

4.3 As inscrições postadas após o período estabelecido no subitem 2.1.2 serão automaticamente indeferidas.

4.4 Caso o concorrente não apresente, no ato da inscrição, a comprovação de que é integrante ou egresso de projetos sociais que desenvolvam atividades de formação para realização de obras audiovisuais, sua inscrição será imediatamente indeferida.

4.5 É vedada a participação de uma pessoa em mais de um projeto, bem como de pessoas que estejam em situação irregular junto à SAv/MinC. 
4.6 Não serão admitidos concorrentes que possuam vínculos empregatícios e/ou contratuais com os membros da Comissão de Seleção e/ou Ministério da Cultura, Associação Brasileira de Canais Comunitários e Coordenação Executiva, bem como de seus familiares ou correlativos até o terceiro grau.

\section{DO PROCESSO SELETIVO}

5.1 A Comissão de Seleção será composta por cinco membros e constituída por especialistas na atividade audiovisual, designados pela SAv/MinC, SAI/MinC e ABCCom.

5.2 A avaliação dos projetos levará em conta os aspectos de originalidade, criatividade artística, adequação ao tema "Cultura e Transformação Social", compatibilidade entre a previsão orçamentária e a realização da obra proposta e o currículo dos concorrentes.

5.2.1 Previamente ao processo seletivo, será tecnicamente analisada pela Coordenação Executiva a condição de habilitação do projeto para participar do presente Concurso, por meio da conferência dos documentos e informações solicitados no Edital.

5.2.1.1 A partir do dia 10 de novembro de 2009, será divulgada lista contendo a relação dos projetos inabilitados, quais sejam, aqueles que não contemplam os documentos e informações exigidos no presente edital, e que, portanto, não serão objeto de análise pela Coordenação Executiva. Os concorrentes que tiverem seus projetos inabilitados poderão apresentar recurso à Coordenação Executiva, sediada no endereço mencionado no item 2.1.2 deste edital, em até 5 (cinco) dias, contados da data de divulgação da inabilitação. Transcorrido esse prazo, não será aceita apresentação de recurso, sendo homologada em caráter definitivo a inabilitação do concorrente.

5.2.2 Para fins de realização da avaliação, a Comissão de Seleção procederá da seguinte forma:

a) Cada um dos membros avaliará todos os projetos habilitados, conforme os critérios definidos no subitem 5.2;

b) Em reunião presencial, a Comissão de Seleção procederá à seleção dos 20 (vinte) projetos aptos ao recebimento do apoio e dos 10 (dez) projetos para 
composição de lista de reserva, em ordem de classificação, para atender vagas surgidas por eventuais desistências ou indeferimentos;

c) Serão contemplados na lista inicial de aprovados, no mínimo, 2 (dois) projetos de, pelo menos, 4 (quatro) macrorregiões do país, se estes forem apresentados.

5.3 A avaliação dos membros da Comissão de Seleção é soberana e irrecorrível.

5.4 A lista dos 20 (vinte) projetos aptos ao recebimento do apoio e dos 10 (dez) projetos integrantes do cadastro de reserva será divulgada a partir do dia 14 de dezembro de 2009. Tal divulgação será veiculada por meio de publicação em portal na Internet, bem como por meio do envio de e-mail ao endereço eletrônico indicado pelos participantes contemplados e pelos integrantes do cadastro de reserva no ato de inscrição.

\section{DA CONTRATAÇÃO E DA PARTICIPAÇÃO DOS SELECIONADOS}

6.1 No prazo máximo de 5 (cinco) dias úteis a contar da divulgação do resultado, sob pena de perda do direito ao apoio, os concorrentes selecionados deverão comprovar sua condição de regularidade civil e fiscal, bem como em relação aos direitos autorais e demais registros que envolverem a obra, mediante o envio dos seguintes documentos:

Documento em papel timbrado, fornecido por uma oficina audiovisual ligada a projeto social, declarando que o realizador participou de, pelo menos, uma de suas edições, oficinas ou projetos;

Autorização de Cessão de Direitos Autorais, caso o projeto faça uso de obra de terceiros.

6.1.1 Ao final da oficina mencionada no subitem 6.3, os concorrentes selecionados deverão, ainda, assinar e devolver o Termo de Compromisso de Realização de Obra Certa e Licença de Utilização, instrumento que regulará a produção de obras audiovisuais digitais inéditas de curta metragem objeto do presente Edital, e o termo de licenciamento mencionado no item 6.7 deste edital. 
6.2 Não serão aceitos protocolos relativos a requerimentos para obtenção da documentação prevista no subitem 6.1.

6.3 Antes da contratação, os contemplados participarão obrigatoriamente de uma oficina de desenvolvimento de projeto, com duração de 5 (cinco) dias, custeada pelo Ministério da Cultura.

6.4 Os responsáveis integrantes da lista de reserva poderão participar, às suas expensas, da oficina de desenvolvimento de projeto, sem que isso implique recebimento de apoio para a produção de vídeos.

6.5 Os contemplados concederão entrevistas à equipe contratada pela Coordenação Executiva, que integrarão, com os filmes de curta-metragem, o programa de televisão "Nós na Tela".

6.6 Será cancelado automaticamente o direito ao apoio ao concorrente selecionado que estiver inadimplente com a Administração Pública Federal, a qualquer tempo, bem como àquele que deixar de cumprir total ou parcialmente os dispostos nos subitens de 6.1 a 6.5 .

6.7 Como condição para a aprovação de projetos fomentados pelo presente edital, os contemplados deverão licenciar ao Ministério da Cultura, por escrito, conforme termo de licenciamento a ser disponibilizado, o direito da utilização da obra a partir de sua conclusão, em caráter não-exclusivo e de forma não-onerosa, em programas e políticas públicas do Ministério da Cultura, bem como a sua reprodução em meios de veiculação de conteúdos fomentados ou geridos pelo Ministério da Cultura, tais como emissoras de radiodifusão, canais de televisão por assinatura, portais na internet, salas de cinema e cineclubes, dentre outros.

6.8 A critério do Ministério da Cultura e sem que sejam devidas compensações financeiras aos contemplados e aos canais comunitários, os filmes de curta metragem produzidos no âmbito do "Nós na Tela" poderão ser exibidos em outros canais e emissoras de televisão, integrantes dos sistemas público e estatal de radiodifusão, 
depois de exibidos, inicialmente, nos canais comunitários participantes deste programa e associados ou não à $\mathrm{ABCCom}$, como parte do programa de televisão "Nós na Tela", a ser produzido por equipe contratada pela Coordenação Executiva.

\section{DO APOIO}

7.1 Serão apoiados 20 (vinte) projetos com valor individual de $\mathrm{R} \$ 30.000,00$ (trinta mil reais), conforme objeto deste Edital, sendo que sua liberação se dará da seguinte forma:

a) $50 \%$ (cinquenta por cento) do orçamento aprovado e selecionado no momento de assinatura dos contratos;

b) $30 \%$ (trinta por cento) do mesmo orçamento, após a entrega do material filmado e de relatório parcial ao fim do terceiro mês de produção;

c) $20 \%$ (vinte por cento) restantes do mesmo, após a entrega de uma cópia da obra concluída, conforme subitem 8.1 alínea "a", e de relatório final de produção.

7.2 É vedada a acumulação do apoio previsto neste Edital com recursos captados por meio das leis 8.313/91 e 8.685/93, bem como com recursos provenientes de outros programas e/ou apoios concedidos por entes públicos federais.

\section{DAS OBRIGAÇÕES DA CONTRATADA}

8.1 Cabe ao contratado cumprir fielmente o disposto no Termo de Compromisso de Realização de Obra Certa e Licença de Utilização, em especial:

a) Entregar à SAv/MinC, no prazo máximo e improrrogável de 120 (cento e vinte) dias, contados da data da liberação da primeira parcela do apoio, 1 (uma) cópia em DVCAM, acompanhada de sinopse, ficha técnica e fotos para divulgação.

b) Divulgar o nome do MINISTÉRIO DA CULTURA, da SECRETARIA DO AUDIOVISUAL, da SECRETARIA DE ARTICULAÇÃO INSTITUCIONAL, do PROGRAMA MAIS CULTURA, da ASSOCIAÇÃO BRASILEIRA DE CANAIS COMUNITÁRIOS, da SOCIEDADE DOS AMIGOS DA CINEMATECA e a MARCA DO GOVERNO FEDERAL, em cartela exclusiva nos créditos iniciais, bem como nos créditos finais, conforme modelo estabelecido pela SAv/MinC e Portaria da SECOM/PR.

c) Participar em eventos de lançamento, mostras e festivais sobre o "Nós na 
Tela”, promovidos pelo Ministério da Cultura, a critério deste.

8.2 No caso de o Contratado não cumprir qualquer dos itens pactuados e/ou não apresentar a cópia mencionada no item 8.1, “a”, conforme as características estabelecidas, deverá devolver ao MinC os recursos financeiros recebidos, atualizados na forma prevista na legislação vigente.

\section{DISPOSIÇÕES GERAIS}

9.1 Para os efeitos deste Edital, entende-se que:

a) Projeto inédito é aquele não realizado ou que não esteja em fase de produção ou finalização;

b) Diretor é aquele que cria e dirige, artística e tecnicamente, a equipe técnica e o elenco ou depoentes, por meio da análise e da interpretação do roteiro do filme, adequando-o à sua realização;

c) Diretor e roteirista é aquele que, além das funções descritas na alínea "b", também é responsável pelo roteiro da obra audiovisual.

\section{2 É expressamente vedada:}

a) A troca ou substituição do Concorrente, a que título for;

b) Qualquer alteração que implique modificação dos documentos que compõem o projeto técnico.

9.3 Os projetos integrantes da lista de reserva poderão ser contemplados posteriormente em caso de disponibilidade de recursos, a critério da Secretaria do Audiovisual e da Sociedade Amigos da Cinemateca, e respeitada a prioridade aos selecionados, a ordem decrescente de pontuação e o prazo de vigência da seleção pública.

9.4 Os projetos inscritos não serão devolvidos em hipótese alguma, independentemente do resultado, ficando o MinC autorizado a incinerá-los após a conclusão do Edital.

9.5 Este Edital será publicado no Diário Oficial da União e estará disponível 
no site do Ministério da Cultura, no endereço eletrônico: www.cultura.gov.br.

9.6 Mais informações sobre o Programa poderão ser obtidas prioritariamente pelo e-mail: nosnatela@cinemateca.org.br, fazendo constar no campo assunto a citação: EDITAL NÓS NA TELA e o Nome do Projeto.

9.7 A inscrição do concorrente implica a prévia e integral concordância com as disposições deste Regulamento.

9.8 Os casos omissos serão dirimidos pela Secretaria do Audiovisual e pela Secretaria de Articulação Institucional do Ministério da Cultura.

SILVIO PIRÔPO DA-RIN

Secretário do Audiovisual

SILVANA MEIRELLES

Secretária de Articulação Institucional

NÓS NA TELA

ANEXO I - REQUERIMENTO DE INSCRIÇÃO

$\mathrm{Eu}$, venho requerer a inscrição do projeto no Concurso de Apoio à

Produção de Obras Audiovisuais Digitais Inéditas, de CURTA METRAGEM, nos gêneros DOCUMENTÁRIO ou TELERREPORTAGEM, sobre o tema "Cultura e Transformação Social”.

Datar e assinatura

Nome Completo -

$\mathrm{RG}-$

$\mathrm{CPF}-$

Endereço (com CEP, cidade e Estado) -

Data de Nascimento -

Oficina audiovisual que freqüentou (incluindo data do curso) -

ANEXAR: 
- Comprovante de residência no Brasil há pelo menos 02 (dois) anos (contas de água, luz, telefone, IPTU, ou extrato bancário, com datas de postagem atual);

- Fotocópia de RG e CPF.

\section{Edital nº3/09/CCJ - Co-patrocínio para Primeiras Obras.}

A Prefeitura do Município de São Paulo, através da Secretaria Municipal de Cultura, torna público que no período de 05 de outubro a 30 de outubro de 2009 estará recebendo no Centro Cultural da Juventude Ruth Cardoso, situado na Avenida Deputado Emílio Carlos, 3.641, Vila Nova Cachoeirinha, Zona Norte, nesta Capital, de segunda a sexta-feira das 13:00 às 17:00 horas, inscrições de propostas dos interessados em participar deste Edital.

\section{OBJETO}

1.1. O presente edital tem por finalidade co-patrocinar a realização de produtos culturais.

1.2. Os projetos que utilizarem recursos multimídia terão prioridade na avaliação da comissão julgadora.

1.3. Considera-se como produto cultural, para fim deste edital, todo trabalho que tem um objeto, obra ou apresentação de natureza artística e cultural.

1.4. Considera-se para fim deste edital que Multimídia é a combinação de pelo menos um tipo de mídia estática (texto, fotografia, gráfico), com pelo menos um tipo de mídia dinâmica (vídeo, áudio, animação, jogos eletrônicos, sites). O termo referese, portanto, às tecnologias com suporte digital para criar, manipular, armazenar e pesquisar conteúdos.

1.5. O produto cultural final deverá ser o principal destino dos recursos deste Edital. 


\section{VALOR E CONDIÇÕES DO INCENTIVO}

2.1. O valor máximo a ser concedido a cada projeto cujo proponente seja pessoa jurídica será de $\mathrm{R} \$ 50.000,00$ (cinquenta mil reais), incluindo as taxas e impostos, que ficarão por conta do selecionado.

2.2. O valor máximo a ser concedido a cada projeto cujo proponente seja pessoa física será de $\mathrm{R} \$ 30.000,00$ (trinta mil reais), incluindo as taxas eimpostos, que ficarão por conta do selecionado.

2.3. O valor aprovado será liberado em duas parcelas, da seguinte forma:

2.3.1. 70\% (setenta por cento) do aporte, até 30 (trinta) dias após a assinatura do termo de co-patrocínio; e

2.3.2. $30 \%$ (trinta por cento) do aporte, até 30 (trinta) dias após a entrega do produto.

2.4. Os direitos autorais morais serão do autor da obra. Os direitos autorais patrimoniais ficam cedidos ao Município de São Paulo para fins não comerciais, por tempo indeterminado.

2.5. Este Edital atenderá até 6 projetos, no máximo.

\section{CONDIÇÕES DE PARTICIPAÇÃO}

3.1. Não poderá se inscrever nem concorrer à seleção de que trata este edital, órgão ou programa da Administração Pública, direta ou indireta, seja ela municipal, estadual ou federal.

3.2. Cada proponente poderá ter somente um projeto selecionado.

3.3 Cada proponente, bem como cada integrante do grupo proponente, somente poderá integrar a ficha técnica de um projeto selecionado.

3.4. Cada proponente poderá inscrever, no máximo, 2 (dois) projetos nesta seleção. 
3.5. Poderão participar desta seleção somente pessoas jurídicas ou pessoas físicas sediadas ou residentes no Município de São Paulo há, pelo menos, dois anos, que atendam a todas as disposições deste Edital, e que não estejam impedidas de serem contratadas pela Administração Pública.

3.6. Na hipótese de pessoa jurídica constituída a menos de dois anos, serão aceitas nesta seleção as inscrições de projetos, desde que seja comprovada a residência dos respectivos sócios no Município de São Paulo, no prazo previsto neste edital.

\section{INSCRIÇÕES}

As propostas e os projetos a serem inscritos deverão ser apresentadas no Centro Cultural da Juventude Ruth Cardoso, situado na Avenida Deputado Emílio Carlos, 3.641, Vila Nova Cachoeirinha, Zona Norte, nesta Capital, de segunda a sextafeira, das 13:00 às 17:00 horas, de 05 de outubro a 30 de outubro de 2009. No ato da inscrição, o proponente deverá entregar dois envelopes, no formato $\mathrm{A} 3$, com as inscrições: "EDITAL n 03/09 - CCJ - COPATROCÌNIO- PRIMEIRAS OBRAS", o nome do projeto e o nome do proponente. O primeiro deverá conter ainda a palavra “DOCUMENTAÇÃO”; o segundo deverá conter a palavra "PROJETO”.

4.1. No ato da inscrição, o primeiro envelope, com a palavra “DOCUMENTAÇÃO”, será conferido e o projeto somente será considerado inscrito se este envelope contiver todos os documentos discriminados abaixo, em cópias simples:

a) requerimento de inscrição preenchido e assinado (Anexo I);

b) ficha síntese preenchida por completo (Anexo II);

c) cartão de Registro no Cadastro Nacional de Pessoa Jurídica - CNPJ, se pessoa jurídica;

d) Cadastro de Pessoa Física (CPF), regular junto a Receita Federal (fotocópia), do representante legal, se pessoa jurídica, ou do proponente, se pessoa física; 
e) Cadastro de Contribuintes Mobiliários - CCM, para pessoa física ou jurídica;

f) carteira de identidade (fotocópia), do representante legal, se pessoa jurídica ou do proponente, se pessoa física;

g) declaração - sob penas da lei - do proponente de que não é funcionário público do Município de São Paulo, se pessoa física ou de que não tem no núcleo artístico responsável pelo projeto nenhum componente que o seja, no caso de pessoa jurídica (anexo III);

h) comprovante do proponente de que reside ou está sediado no Município de São Paulo nos últimos dois anos. Na hipótese de pessoa jurídica constituída a menos de dois anos, comprovante de residência dos respectivos sócios no Município de São Paulo no prazo mencionado.

4.2. Os documentos referidos no item 4.1. deste edital devem ser reapresentados, nos originais ou fotocópias autenticadas, por ocasião da lavratura do termo de co-patrocínio.

4.3. O segundo envelope, com a palavra "PROJETO", deverá estar lacrado e conter 3 (três) cópias dos seguintes documentos:

a) exposição clara do trabalho ou obra final, na qual constem justificativa, objetivo e o produto a ser desenvolvido (no máximo duas laudas);

b) plano de trabalho para a produção, contendo:

I - cronograma detalhado;

II - descrição das atividades a serem desenvolvidas;

III - descrição dos recursos materiais necessários;

IV - orçamento completo e detalhado;

V - plano de divulgação e apresentação.

c) informações complementares que o proponente julgar necessárias para a avaliação do projeto (texto ou roteiro, storyboards, DVD's, CD's, fotos, livros, etc.)

d) portfólio e currículo dos principais componentes do grupo ou do proponente.

4.4. O não cumprimento destas instruções acarretará na automática 
desclassificação do projeto.

\section{COMISSÃO DE SELEÇÃO}

5.1. Para selecionar os projetos, será nomeada pela Secretaria Municipal da Cultura uma comissão de seleção formada por até 08 (oito) membros com reconhecida competência na área cultural.

5.2. A Secretaria Municipal de Cultura publicará no Diário Oficial da Cidade a composição da Comissão de Seleção.

5.3. Nenhum membro da Comissão de Seleção poderá participar de forma alguma de projeto concorrente ou ter quaisquer vínculos profissionais ou empresariais com as proposta apresentadas, ou de parentesco com os sócios, acionistas e diretores da proponente.

5.4. A comissão de seleção priorizará projetos que se valham de recursos multimídia e as iniciativas culturais de caráter coletivo, e terá como critérios para a seleção:

a) a clareza e qualidade da proposta apresentada;

b) a compatibilidade com o objetivo deste edital;

c) a coerência do orçamento com a proposta apresentada;

d) a relevância, pertinência e interesse cultural do produto a ser desenvolvido;

e) o portfólio e currículo do proponente;

f) a diversidade, por linguagem artística e por região da cidade, do conjunto de propostas selecionadas.

5.5. Os critérios de julgamento deverão ser observados pela Comissão de Seleção, que apresentará a decisão nas respectivas atas. Na relação dos selecionados, a Comissão indicará uma lista suplementar com 3 (três) projetos para casos de eventual desistência ou impossibilidade de contratação.

5.6. A comissão de seleção lavrará em ata o resultado que será publicado pela Secretaria Municipal de Cultura no Diário Oficial da Cidade. 
5.7. A Comissão poderá deixar de utilizar a totalidade dos recursos disponíveis previsto no item 2.3 deste edital se julgar que os projetos apresentados não atendem aos objetivos do edital.

5.8. A Comissão poderá, a seu critério, solicitar esclarecimentos a assessores técnicos ou aos proponentes de algum dos projetos apresentados.

5.9. A Comissão julgadora decidirá sobre os casos não previstos no edital.

5.10. A Comissão é soberana, não cabendo recurso hierárquico de suas decisões.

\section{PRAZOS}

6.1. Até 30 (trinta) dias após o julgamento dos projetos, a Secretaria Municipal de Cultura deverá notificar os vencedores que terão o prazo de 5 (cinco) dias contados do recebimento da notificação para manifestarem, por escrito, se aceitam ou desistem da realização do produto cultural.

6.2. Em caso de desistência ou problemas de documentação, o Centro Cultural da Juventude Ruth Cardoso terá o prazo de 5 (cinco) dias para notificar novos vencedores, sem prejuízo dos demais selecionados.

6.3. A Secretaria Municipal de Cultura homologará e publicará no Diário Oficial da Cidade a seleção de projetos da Comissão de Seleção e as alterações previstas no item anterior.

6.4. O proponente terá até 5 (cinco) meses para realizar o projeto e entregar o produto cultural, contados da data do recebimento da primeira parcela.

\section{DO CO-PATROCÍNIO E PAGAMENTO}

7.1 Até 20 dias após cada publicação prevista no item 6.3. O Centro Cultural da Juventude providenciará a lavratura do termo de co-patrocínio para cada projeto. 
7.2 Os responsáveis pelos projetos selecionados deverão apresentar os seguintes documentos para a formalização do termo de co-patrocínio:

a) cópia do Cadastro Nacional de Pessoa Jurídica - CNPJ ou do Cadastro de Pessoa Física - CPF, junto à Receita Federal;

b) cópia da inscrição no Cadastro de Contribuinte Mobiliários - CCM;

c) Certidão Negativa de Débitos - CND/INSS; se pessoa jurídica ou número de inscrição na autarquia, se pessoa física;

d) Certidão de Regularidade Fiscal - CRF/FGTS, se pessoa jurídica;

e) cópia de Certidão Negativa de Tributos Municipais;

f) comprovante de inexistência de pendências no CADIN MUNICIPAL Cadastro Informativo Municipal;

g) contrato social ou estatuto com todas as alterações, com firmas reconhecidas e cópias autenticadas, se pessoa jurídica;

h) última ata de eleição da Diretoria, com firmas reconhecidas e cópias autenticadas, se pessoa jurídica;

i) cópia do cadastro de pessoa física e documento de identificação do responsável legal da empresa;

j) número da agência e conta bancária aberta exclusivamente para a realização do projeto, no Banco Bradesco S.A, conforme determina o Decreto Municipal $\mathrm{n}^{\circ}$ 46.528 , de 20/10/2005.

7.3. O projeto selecionado para o co-patrocínio somente poderá ser alterado mediante autorização da Comissão de Seleção ou do Centro Cultural da Juventude.

\section{DA PRESTAÇÃO DE CONTAS}

8.1. O partícipe (pessoa jurídica ou física) do projeto deverá apresentar ao Centro Cultural da Juventude prestação de contas no prazo de até 30 (trinta) dias do recebimento da última parcela, comprovando a utilização dos recursos conforme o projeto apresentado.

8.2. O partícipe fornecerá cópia do extrato bancário mensal relativo à conta bancária exclusiva para o projeto. 
8.3. As despesas serão comprovadas mediante documentos originais fiscais ou equivalentes (ou cópias acompanhadas do original para certificação pelos funcionários responsáveis), organizadas conforme os itens do orçamento aprovado, incluindo lista dos documentos para conferência.

8.4. As faturas, os recibos, notas fiscais e quaisquer outros documentos comprobatórios deverão ser emitidos em nome do partícipe do projeto, devidamente identificados com referência ao nome do projeto.

8.5. A prestação de contas será analisada pelo setor técnico do Centro Cultural da Juventude e submetida à aprovação pela Secretaria Municipal de Cultura.

8.6. A não aprovação da prestação de contas do projeto na forma estabelecida no item anterior sujeitará o partícipe a devolver o total das importâncias recebidas, acrescidas da respectiva atualização monetária, e multa prevista neste edital (9.4) em até 30 (trinta) dias da publicação do despacho que as rejeitou.

8.7. A não devolução da importância no prazo e forma assinalados caracterizará a inadimplência do partícipe e de seus responsáveis legais, que ficam impedidos de firmar novos projetos ou contratos com a Municipalidade ou receber qualquer apoio dos órgãos municipais.

8.8. As responsabilidades civis, penais, comerciais, e outras advindas de utilização de direitos autorais e/ou patrimoniais anteriores, contemporâneas ou posteriores à formalização do termo de co-patrocínio cabem exclusivamente ao partícipe.

8.9. A Secretaria Municipal de Cultura não se responsabilizará em hipótese alguma pelos atos, contratos ou compromissos assumidos de natureza comercial, financeira, trabalhista ou outra, realizado pelo partícipe para fins do cumprimento do termo de co-patrocínio com a Prefeitura do Município de São Paulo (Secretaria Municipal de Cultura). 


\section{PENALIDADES}

9.1. O partícipe que durante a execução alterar as características do projeto selecionado, sem prévia autorização do Centro Cultural da Juventude estará sujeito ao imediato bloqueio da liberação da próxima parcela e, se o projeto não for reconduzido às características com as quais foi apresentado, dentro do prazo contratualmente estabelecido, à rescisão do termo de co-patrocínio, com a consequente devolução dos valores recebidos, corrigidos monetariamente a contar da data do recebimento.

9.2. O não cumprimento do projeto tornará inadimplente o partícipe, seus responsáveis legais e os membros do núcleo artístico, que, uma vez assim declarados, não poderão efetuar qualquer contrato ou receber qualquer apoio dos órgãos municipais por um período de cinco anos.

9.3. O partícipe, pessoa jurídica, que tiver na equipe técnica ou artística do projeto algum integrante que seja funcionário público municipal, terá o projeto desclassificado e o integrante estará sujeito às sanções previstas no Estatuto do Servidor Público Municipal.

9.4. O partícipe inadimplente será obrigado a devolver o total da importância recebida no Projeto, acrescida da respectiva atualização monetária e estará sujeito à aplicação de multa no valor de até $50 \%$ (cinquenta por cento) do valor do copatrocínio.

9.5. O partícipe que descumprir as demais obrigações que lhe são cometidas pelo termo de co-patrocínio estará sujeito a:

a) rescisão do termo de co-patrocínio com a consequente devolução dos valores recebidos, corrigidos monetariamente a contar da data do recebimento, além da multa prevista no item 9.5;

b) ser declarado inidôneo para licitar, contratar ou receber qualquer apoio da Administração Pública, pelo prazo mínimo de cinco anos e enquanto perdurarem os motivos determinantes da punição ou até que seja promovida a reabilitação perante o órgão que aplicou a penalidade, que só será concedida se o partícipe ressarcir a 
Administração pelos prejuízos resultantes.

9.6. Aplicam-se a este capítulo, no que couber, as disposições dos artigos 54 e 55 do Decreto Municipal $n^{\circ} 44.279 / 03$, combinados com o $\S 1^{\circ}$ do artigo 15 do Decreto Municipal no 46.888/06.

\section{DISPOSIÇÕES FINAIS}

10.1. Os projetos não selecionados ficarão à disposição do proponente pelo prazo de 20 (vinte) dias contados da divulgação final da seleção no Diário Oficial do Município de São Paulo. Após essa data serão eliminados a critério do Centro Cultural da Juventude.

10.2. Cópia deste edital e seus anexos poderão ser encontradas no site do Centro Cultural da Juventude (http://centrodajuventude.prefeitura.sp.gov.br), ou no site da Secretaria Municipal de Cultura (http://www.prefeitura.sp.gov.br/cultura).

10.3. Eventuais dúvidas sobre o edital deverão ser formalmente encaminhadas por escrito ao Centro Cultural da Juventude até 5 (cinco) dias antes do encerramento das inscrições

Prefeitura do Município de São Paulo

Secretaria Municipal de Cultura

Centro Cultural da Juventude Ruth Cardoso

São Paulo,

Publique-se.

\section{ANEXO I - Modelo de requerimento de inscrição}

São Paulo, (dia) de (mês) de 2009.

Secretaria Municipal de Cultura de São Paulo

Exmo. Sr. Secretário 
Referência: "Produção Cultural - Primeiras Obras".

Edital no $^{\circ}$ 02/2008/CCJ. ${ }^{\circ}$

Projeto

Proponente

(nome pessoa física/jurídica proponente do projeto), inscrita no $\mathrm{CNPJ} / \mathrm{CPF}$ n. ${ }^{\circ}$

residente/com

sede

(endereço completo, cep,

telefone)

(aqui

representado

pelo

Sr. (representante legal),

$\begin{array}{lllll}\text { portador da } & \text { Cédula } & \text { de } & \text { Identidade }\end{array}$

N. ${ }^{\circ}$

e CPF n.

,se

pessoa jurídica) venho requerer a inscrição do Projeto denominado , de acordo com a exigência do Edital publicado no Diário Oficial do Município de São Paulo, no dia de de 2009.

Envio, anexos, o "Projeto" e a documentação exigidos neste Edital, de cujos termos declaro estar ciente e de acordo.

Atenciosamente,

Nome e assinatura do proponente

\section{ANEXO II}

Nome do Projeto:

Nome/Razão Social da Proponente:

Nome do representante legal, se pessoa jurídica:

Telefones:

Endereço/Sede: I 
Representante legal, se pessoa jurídica:

E-mail:

Subprefeitura e bairro de localização da Proponente:

Bairro: Subprefeitura:

Tempo de existência com CNPJ (em anos), se pessoa jurídica:

Objeto ou Área(s) de Atuação da Proponente:

Possui outras formas de apoio/financiamento? ( ) Sim ( ) Não - Se SIM, preencha o campo abaixo:

( ) Órgão Público, Qual(is)?

( ) Iniciativa Privada, Qual(is)?

Nome dos integrantes do grupo executor do projeto, se pessoa jurídica:

$1-$ Idade:

2 Idade:

$3-$ Idade:

4 Idade:

$5-$ Idade:

$6-$ Idade:

7 Idade:

$8-$ Idade:

9 Idade:

10 Idade:

Assinale o produto previsto no projeto:

( ) Exibição (filmes, vídeos, audiovisuais, multimídia)

( ) Distribuição (livros, CD’s, DVD’s, outras mídias)

( ) Exposição

( ) Apresentação de Espetáculo

( ) Eventos 
( ) Filme

( ) Outros. Quais?

Custo total do projeto: $\mathrm{R} \$$

Prazo de realização do projeto: (período, meses)

Breve descrição do produto:

Breve descrição da contrapartida para a Cidade de São Paulo da Proposta DO PONTO DE VISTA DO VALOR CULTURAL:

RESUMO DO ORÇAMENTO:

\begin{tabular}{|c|c|}
\hline $\begin{array}{l}\text { 1-DESPESAS } \quad \text { DE } \\
\text { PRODUÇÃO }\end{array}$ & $\mathrm{R} \$$ \\
\hline 2-DESPESAS DE PRODUÇÃO & $\mathrm{R} \$$ \\
\hline 3-DESPESAS & $\mathrm{R} \$$ \\
\hline DIVULGAÇÃO (LIMITADA A 10\% DA & \\
\hline SOMATÓRIA DASDESPESAS DE PRÉ & \\
\hline PRODUÇÃO E PRODUÇÃO ATÉ O & \\
\hline MAXIMO $\quad \mathrm{DE} \quad \mathrm{R} \$ 15.000,00 \quad \mathrm{DO}$ & \\
\hline PROJETO) & \\
\hline 4-DESPESAS & $\mathrm{R} \$$ \\
\hline ADMINISTRAÇÃO (LIMITADA A & \\
\hline 10\% DA SOMATÓRIA DOS ITENS DE & \\
\hline PRÉ PRODUÇÃO E PRODUÇÃO DO & \\
\hline PROJETO) & \\
\hline 5-VALOR & $\mathrm{R} \$$ \\
\hline
\end{tabular}


AGENCIAMENTO (LIMITADA A 10\%

DA SOMATÓRIA DAS DESPESAS DE PRÉ PRODUÇÃO E PRODUÇÃO DO PROJETO, ATÉ O MAXIMO DE R\$ $15.000,00)$

\section{É OBRIGATÓRIO O PREENCHIMENTO COMPLETO DESTA FICHA}

\section{ANEXO III - MODELO DE DECLARAÇÃO}

São Paulo, de de 2009. (nome pessoa física/juridica -

proponente do projeto), inscrita no $\mathrm{CPF} / \mathrm{CNPJ} \quad$. $^{\circ}$ residente/com sede à (endereço completo, cep, telefone) (aqui representado pelo $\mathrm{Sr}$. (representante legal) portador da Cédula de Identidade $\mathrm{RG} \mathrm{n}^{\mathrm{o}}$ e $\mathrm{CPF}$ n. ${ }^{\circ}$ se pessoa jurídica) DECLARA, sob as penas da lei, que não é funcionário público do Município de São Paulo (se pessoa física)/ que não tem na equipe técnica ou artística responsável pelo projeto de que trata o "Edital de Produção Cultural - Primeiras Obras" nenhum componente que seja funcionário público do Município de São Paulo (se pessoa jurídica).

assinatura(s) do proponente/representante(s) legal(is)

\section{Anexo O - Edital de Egressos}

\section{MINISTÉRIO DA CULTURA}

SECRETARIA DO AUDIOVISUAL

EDITAL DE CONCURSO Nº2, DE 23 DE NOVEMBRO DE 2007

O Ministério da Cultura - MinC, por meio da Secretaria do Audiovisual - SAV, torna público o Concurso de Apoio à Produção de Obras Audiovisuais Digitais 
Inéditas, de CURTA METRAGEM, dos GÊNEROS FICÇÃO, DOCUMENTÁRIO OU EXPERIMENTAL, destinado exclusivamente a pessoas físicas integrantes ou egressas de projetos sociais com foco na linguagem audiovisual, desenvolvidos por entidades sem fins lucrativos, instituído pela Portaria ${ }^{\circ} 063$, de 22 de novembro de 2007, publicada no Diário Oficial da União de 23 de novembro de 2007, nas condições e exigências estabelecidas neste Edital, em conformidade com a Lei $\mathrm{n}^{\circ}$ 8.666, de 21 de junho de 1993.

\section{DO OBJETO}

Apoiar a produção de obras audiovisuais digitais inéditas de curta metragem, dos gêneros ficção, documentário ou experimental, com duração entre 10 e 15 minutos, exclusivamente para integrantes ou egressos de projetos sociais com foco na linguagem audiovisual.

\section{DA PARTICIPAÇÃ̃O}

2.1 Somente poderão concorrer ao presente concurso PESSOAS FÍSICAS, a partir de 18 anos, com comprovação de ser integrante ou egresso de projetos sociais com foco na linguagem audiovisual, desenvolvidos por entidades sem fins lucrativos, e que se apresentem como diretor ou diretor e roteirista.

2.1.1 A responsabilidade quanto à comprovação de que o concorrente foi ou é integrante de projeto social será apresentada por documento, reconhecido em cartório e firmado pelo responsável de entidade sem fins lucrativos, que desenvolvam projetos sociais com foco na linguagem audiovisual.

2.1.2 O Requerimento de Inscrição, Anexo I e o Projeto Técnico deverão ser encaminhados no mesmo envelope, através dos serviços de postagem de correspondência da Empresa Brasileira de Correios e Telégrafos - ECT, na modalidade de SEDEX, no período DE 27 DE NOVEMBRO DE 2007 A 29 DE FEVEREIRO DE 2008, fazendo constar no endereçamento do envelope os seguintes dados:

CAIXA POSTAL No 09669

CONCURSO CURTA FICÇÃO, DOCUMENTÁRIO OU 


\section{EXPERIMENTAL - \\ CIDADANIA AUDIOVISUAL - 2007 \\ BRASÍLIA - DF / CEP: 70040-976}

2.1.3 A Concorrente deverá fazer constar no envelope, no espaço destinado ao remetente, além de seu nome e endereço completo, o NOME DO PROJETO e EMAIL, para confirmação do recebimento da correspondência.

\section{DOS DOCUMENTOS E DO PROJETO TÉCNICO}

3.1 O Requerimento de Inscrição, Anexo I a este Edital, deverá ser encaminhado em 1 (uma) via, com todos os campos preenchidos, devidamente assinado e em separado do Projeto Técnico.

3.2 O PROJETO TÉCNICO deverá ser encaminhado em 7 (sete) vias, contendo os documentos abaixo relacionados:

a) Justificativa, com no máximo 25 (vinte e cinco) linhas;

b) Roteiro, obrigatoriamente, com divisão por seqüência e com diálogos desenvolvidos; Exceto para os projetos de documentário, que deverão colocar apenas um pré-roteiro ou roteiro indicativo, com lista de possíveis entrevistados, locações e outras informações relevantes para a compreensão do mesmo. Em todos gêneros, não poderá ser ultrapassado o limite de 19 laudas.

c) Orçamento detalhado, com custo global de produção e cópias, conforme previsto no subitem 8.1, alínea “a”, de NO MÁXIMO R\$ 30.000,00 (trinta mil reais), dividido por etapas de préprodução, produção e finalização, contendo a descrição das respectivas despesas, seus quantitativos, custos unitários e totais, com no máximo 4 (quatro) laudas.

d) Currículo do Diretor e Descrição das atividades da instituição produtora, conforme Anexo II.

3.3 Os documentos acima citados deverão ser formatados e impressos em papel A4, margem esquerda de 2,5 cm e direita de $1,5 \mathrm{~cm}$, entrelinhas de $1,5 \mathrm{~cm}$, fonte Times New Roman e tamanho 12 (doze), contendo a citação expressa de seus 
respectivos títulos, com laudas seqüencialmente numeradas, rubricadas e montadas em grampos com duas perfurações.

\section{DOS IMPEDIMENTOS E MOTIVOS PARA INDEFERIMENTO DA} INSCRIÇÃO

4.1 A falta de apresentação de quaisquer dos documentos, ou em desacordo com o estabelecido no item 3, implicará no imediato indeferimento da inscrição.

4.2 A apresentação de orçamento em valor superior a $\mathrm{R} \$ 30.000,00$ (trinta mil reais), ainda que em centavos, implicará no imediato indeferimento da inscrição.

4.3 As inscrições postadas após o período estabelecido no subitem 2.1.2 serão automaticamente indeferidas.

4.4 Caso o concorrente não apresente, no ato da inscrição, a comprovação de que é integrante ou egresso de projetos sociais com foco na linguagem audiovisual, desenvolvidos por entidades sem fins lucrativos, sua inscrição será imediatamente indeferida.

4.5 É vedada a participação de uma pessoa em mais de um projeto, bem como de pessoas que estejam em situação irregular junto à Sav/MinC.

4.6 Não serão admitidas inscrições de pessoas, direta ou indiretamente ligadas aos membros da Comissão de Especialistas na Área Audiovisual, nas condições de cônjuge, parentes até o terceiro grau, inclusive afins e dependentes.

\section{DO PROCESSO SELETIVO E DA COMISSÃO DE ESPECIALISTAS} NA ÁREA AUDIOVISUAL

5.1 A Comissão de Especialistas na Área Audiovisual será constituída por especialistas na atividade audiovisual, designados pela SAV/MinC e, na medida do possível, com representantes das várias regiões brasileiras, sendo que a presidência caberá a seu titular. 
5.2 O processo seletivo será realizado em duas fases distintas, SENDO A PRIMEIRA DE CLASSIFICAÇÃO REGIONAL DE PROJETOS E A SEGUNDA DESTINADA À SELEÇÃO NACIONAL DE PROJETOS, sendo que em ambas as fases a avaliação levará em conta os aspectos de criatividade artística, comunicabilidade, compatibilidade entre a previsão orçamentária e a realização da obra proposta e a descrição/histórico das atividades da instituição produtora;

5.2.1 Previamente às fases do processo seletivo, será tecnicamente analisada a condição de habilitação do projeto para participar do presente Concurso, através da conferência dos documentos/itens e informações solicitados no Edital;

5.2.2 PRIMEIRA FASE - CLASSIFICAÇÃO REGIONAL: Nesta fase, cada um dos projetos será avaliado individualmente, por no mínimo 3 (três) membros da Comissão e, na forma abaixo a saber:

Os membros da Comissão, após análise detalhada do projeto, conforme os aspectos definidos no subitem 5.2, atribuirão nota de 1 (um) a 5 (cinco) pontos a cada projeto analisado. Da soma total das notas, obter-se-á por meio de média aritmética simples, a nota final de cada projeto, classificando para participação na Fase de Seleção Nacional, dentre aqueles que obtiverem, em ordem decrescente de notas finais, um total de no máximo $10 \%$ (dez por cento) do número de projetos avaliados, devendo ainda ser observado o seguinte critério:

a) No mínimo, se possível, 8 (oito) projetos de cada região do país.

5.2.3 SEGUNDA FASE - SELEÇÃO NACIONAL: Para fins de realização da segunda e última fase, a Comissão de Especialistas na Área Audiovisual procederá da seguinte forma:

a) Cada um dos membros avaliará todos os projetos classificados na fase anterior, conforme os aspectos definidos no subitem 5.2;

b) Em reunião presencial, a Comissão de Especialistas na Área Audiovisual, procederá à seleção, em ordem de relevância, sem pontuação, dos 20 (vinte) projetos aptos ao recebimento do apoio e, 10 (dez) projetos para composição de lista de reserva, para atender vagas surgidas por eventuais desistências ou indeferimentos.

c) A seleção observará a distribuição do apoio obrigatório a no mínimo 2 
(dois) projetos de cada região do país;

5.3 Quando da definição dos projetos classificados e/ou selecionados, em qualquer fase, em persistindo situação de empate, a Comissão se reunirá especificamente para decidir, em caráter irrevogável, o desempate.

5.4 Para realização de todo o processo seletivo, será observado o critério de representatividade regional para constituição da Comissão de Especialistas na Área audiovisual.

5.5 A avaliação dos membros da Comissão, tomada individualmente, é soberana e irrecorrível.

\section{DA CONTRATAÇÃO E PARTICIPAÇÃO DOS SELECIONADOS}

6.1 As concorrentes selecionadas deverão comprovar a condição de regularidade civil e fiscal, bem como em relação aos direitos autorais e demais registros que envolverem a obra, no prazo máximo de 5 (cinco) dias úteis a contar do recebimento da comunicação do resultado, sob pena de perda do direito ao apoio;

6.1.1 As concorrentes selecionadas deverão ainda, assinar e devolver juntamente com a documentação exigida no subitem 6.1, a Autorização para Gestão de Conta Corrente Vinculada e de Movimento e o Contrato de Realização de Obra Certa e Licença de Utilização, conforme Anexos III e IV a este Edital.

6.2 Não serão aceitos protocolos relativos a requerimentos para obtenção da documentação prevista neste item.

6.3 Será cancelado automaticamente o direito ao apoio à Concorrente Selecionada que estiver inadimplente com a Administração Pública Federal, a qualquer tempo, bem como deixar de cumprir total ou parcialmente os dispostos nos subitens 6.1, 6.1.1 e 6.2 acima.

\section{DO APOIO}


7.1 O recurso financeiro concedido será depositado em contas correntes sob a titularidade da Contratada, aberta pela SAV/MinC, conforme Autorização para Gestão de Conta Corrente Vinculada e de Movimento.

7.2 Serão apoiados 20 (vinte) projetos com valor individual de até $\mathrm{R} \$$ 30.000,00 (trinta mil reais), conforme objeto deste Edital, sendo que sua liberação se dará da seguinte forma:

a) $50 \%$ (cinqüenta por cento) do orçamento aprovado e selecionado para o início dos trabalhos;

b) $30 \%$ (trinta por cento) do mesmo orçamento, após a entrega do material filmado e de relatórios parciais de produção, em formato a ser definido pela $\mathrm{SAV} / \mathrm{MinC}$;

c) $20 \%$ (vinte por cento) restantes do mesmo, após a entrega de uma cópia da obra concluída, conforme subitem 8.1 alínea "a", e de relatório final de produção, em formato a ser definido pela SAV/MinC.

7.3 É vedada a acumulação do apoio previsto neste Edital com recursos captados através das leis 8.313/91 e 8.685/93, bem como com recursos provenientes de outros programas e/ou apoios concedidos por entes públicos federais.

\section{DAS OBRIGAÇÕES DA CONTRATADA}

8.1 Cumprir fielmente o disposto no Contrato de Realização de Obra Certa e Licença de Utilização, conforme Anexo IV a este Edital e, em especial:

a) Entregar a SAv/MinC, no prazo máximo e improrrogável de 365 (trezentos e sessenta e cinco) dias, contados da data da liberação da primeira parcela do apoio, 1 (uma) cópia em DVD.

b) Divulgar o nome da SECRETARIA DO AUDIOVISUAL, do MINISTÉRIO DA CULTURA e a MARCA DO GOVERNO FEDERAL, em cartela exclusiva nos créditos iniciais, bem como nos créditos finais, conforme modelo estabelecido pela SAv/MinC e Portaria da SECOM/PR.

c) Licenciar ao Ministério da Cultura, em caráter definitivo, a utilização da obra em quaisquer modalidades, para utilização exclusiva em suas finalidades institucionais, sem qualquer intuito de lucro e de forma a não prejudicar a exploração 
econômica da obra, inclusive na promoção de mostras e ações de difusão, bem como a distribuição e exibição nacional e internacional nas televisões públicas e educativas brasileiras, em sinal aberto e fechado.

8.2 No caso da Contratada não cumprir qualquer dos itens pactuados e/ou não apresentá-los conforme as características estabelecidas, deverá devolver ao MinC os recursos financeiros recebidos, atualizados na forma prevista na legislação vigente.

\section{DISPOSIÇÕES GERAIS}

9.1 Para os efeitos deste Edital, entende-se que:

a) Projeto inédito é aquele não realizado ou que não esteja em fase de produção ou finalização;

b) Diretor é aquele que cria e dirige, artística e tecnicamente, a equipe técnica e o elenco ou depoentes, através da análise e interpretação do roteiro do filme, adequando-o à sua realização;

c) Diretor e roteirista é aquele que, além das funções descritas na alínea "b" também é

responsável pela criação da literalidade da obra audiovisual.

d) Média aritmética simples é o valor resultante do somatório de todas as notas, recebidas por um mesmo projeto, dividido pela quantidade dessas mesmas notas.

e) Conta corrente vinculada é aquela aberta pela SAV/MinC, com finalidade exclusiva de recebimento de créditos referentes ao apoio concedido nos termos do presente Edital;

f) Conta corrente de movimentação é aquela aberta pela SAV/MinC, com finalidade exclusiva de recebimento de créditos mediante a transferência de numerários oriundos da Conta Corrente Vincula, à ordem da SAV/MinC, para execução exclusiva do projeto.

9.2 É expressamente vedada:

a) A troca da Concorrente;

b) Qualquer alteração que implique modificação dos documentos que compõem o projeto técnico, bem como o item 3.2. 
9.3 O Prazo para interposição de recursos é de 5 dias úteis, a contar da data de recebimento da informação acerca do indeferimento na fase de habilitação.

9.4 Os projetos inscritos não serão devolvidos em hipótese alguma, independentemente do resultado, ficando o MinC autorizado a incinerá-los após a conclusão do Edital.

9.5 Este Edital será publicado no Diário Oficial da União e estará, juntamente com seus anexos I, II, III e IV, disponível no site do Ministério da Cultura, no endereço eletrônico: www.cultura.gov.br

9.6 Mais informações poderão ser obtidas prioritariamente pelo e-mail: concursos.sav@minc.gov.br, fazendo constar no campo assunto a citação: EDITAL $\mathbf{n}^{0} 02$ e o Nome do Projeto.

9.7 Os casos omissos serão dirimidos por esta Secretaria.

TÂNIA LEITE

Secretária do Audiovisual Interina 